Рецензируемый и реферируемый научно-практический журнал Издается с 2008 г.

Выходит 6 раз в год + приложения

\section{УЧРЕДИТЕЛИ}

Общество с ограниченной ответственностью

«Многопрофильный медицинский центр

«Современная клиническая медицина»

при участии ГБОУ ВПО «Казанский

государственный медицинский университет» МЗ РФ

Журнал зарегистрирован Федеральной службой по надзору в сфере связи, информационных технологий и массовых коммуникаций

(Роскомнадзор). Свидетельство

ПИ № ФС 77-41624 от 11.08.2010.

Перерегистрирован 26.04.2013 г.

Свидетельство ПИ № ФС 77-53842

Языки русский и английский

Подписной индекс журнала в каталоге «Пресса России» 41628

Каталог Казахстана 41628

Адрес редакции и издателя: 420043, Республика Татарстан,

г. Казань, ул. Вишневского, 57-83 Контактные телефоны:

(843) 291-26-76, (843) 277-88-84 (факс) e-mail: vskmjournal@gmail.com

Отдел договоров и рекламы. Тел. +7-903-307-99-47

Контактное лицо - руководитель Амирова Рената Наилевна e-mail: renata1980@mail.ru

\section{Доступен на сайтах:}

http://www.vskmjournal.org, www.kgmu.kcn.ru, www.elibrary.ru, cyberleninka.ru, www.es.rae.ru/vskm, twitter.com/vskmjournal Редколлегия журнала

может не разделять точку зрения авторов на ту или иную проблему

Рукописи не возвращаются, любое воспроизведение опубликованных материалов без письменного согласия редакции не допускается. Ответственность за содержание рекламы несет рекламодатель. Все рекламируемые в данном издании лекарственные препараты, изделия медицинского назначения и медицинское оборудование имеют соответствующие регистрационные удостоверения и сертификаты соответствия.

Компьютерное сопровождение, сайт журнала и версия в Интернет: Шаймуратов Рустем Ильдарович, e-mail: russtem@gmail.com В авторской редакции. Обложка художника С.Ф.Сафаровой. Техническая редакция Ю.Р.Валиахметовой. Верстка Т.Д.Торсуевой. Корректор Н.А.Петрова

Формат 60×84 $1 / 8$. Подписано в печать 13.02.15 Усл.печ.л. 11,63. Тираж 3000 экз. Заказ 15-2 Цена договорная

Оригинал-макет изготовлен издательством «Медицина» ГАУ «РМБИЦ». 420059 Казань, ул. Хади Такташа, 125. Отпечатано отделом оперативной полиграфии ГАУ «РМБИЦ». 420059 Казань, ул. Хади Такташа, 125 ( ) ООО МмЦ «Современная клиническая медицина», 2015 (c) КГМУ Минздрава РФ, 2015

\section{ВЕСТНИК \\ СОВРЕМЕННОЙ КЛИНИЧЕСКОЙ МЕДИЦИНЫ}

\section{VESTNIK SOVREMENNOI KLINICHESKOI MEDICINY}

\author{
НАУЧНО-ПРАКТИЧЕСКИЙ ЖУРНАЛ
}

\section{Том 8, выпуск 12015}

\section{РЕДАКЦИОННАЯ КОЛЛЕГИЯ \\ Главный редактор}

Амиров Наиль Багаувич, д.м.н., проф. кафедры общей врачебной практики ГБОУ ВПО КГМУ, заслуженный деятель науки и образования, акад. РАE, заслуженный врач РТ, лауреат Гос. премии РТ в области науки и техники, e-mail: namirov@mail.ru

\section{Заместитель главного редактора}

Визель Александр Андреевич, д.м.н., проф., зав. кафедрой фтизиопульмонологии ГБОУ ВПО КГМУ, акад. АН РН, заслуженный врач РТ, лауреат Гос. премии РТ в области науки и техники, e-mail: lordara@mail.ru

\section{Ученый секретарь}

Хазова Елена Владимировна, к.м.н., ассистент кафедры пропедевтики внутренних болезней ГБОУ ВПО КГМУ,

e-mail: hazova_elena@mail.ru

\section{Члены редколлегии}

Альбицкий Валерий Юрьевич, д.м.н., проф., заслуженный деятель науки РФ, лауреат премии Правительства РФ в области науки и техники, руководитель отдела социальной педиатрии РАМН (Москва), e-mail: albicky@nczd.ru;

Амиров Наиль Хабибуллович, д.М.Н., проф. кафедры медицины труда

ГБОУ ВПО КГМУ, академик РАМН, e-mail: amirovn@yandex.ru;

Анисимов Андрей Юрьевич, д.м.Н., проф. кафедры скорой

медицинской помощи, медицины катастроф и мобилизационной подготовки здравоохранения ГБОУ ДПО КГМА,

e-mail: aanisimovbsmp@yandex.ru;

Галявич Альберт Сарварович, Д.М.Н., проф., зав. кафедрой факультетской терапии ГБОУ ВПО КГМУ, член-корр. АН РТ, вице-президент

ВНОК, заслуженный врач РТ и РФ, e-mail: agalyavich@mail.ru;

Зиганшин Айрат Усманович, д.м.н., проф., зав. кафедрой фармакологии, проректор ГБОУ ВПО КГМУ по международной деятельности, лауреат Гос. премии РТ в области науки и техники, e-mail: auziganshin@gmail.com;

Киясов Андрей Павлович, д.м.н., проф., директор Института фундаментальной медицины и биологии КФУ, член-корр. АН РТ, e-mail: APKiyasov@ksu.ru;

Менделевич Владимир Давыдович, д.М.н., проф., зав. кафедрой медицинской и общей психологии ГБОУ ВПО КГМУ, e-mail: mend@tbit.ru;

Никольский Евгений Евгеньевич, зав. кафедрой медицинской и биологической физики с информатикой и медицинской аппаратурой

ГБОУ ВПО КГМУ, академик РАН по отделению физиологии

и фундаментальной медицины, зам. председателя КазНЦ РАН по научной работе, e-mail: eenik1947@mail.ru;

Созинов Алексей Станиславович, Д.М.н., проф., ректор ГБОУ ВПО КГМУ, лауреат Гос. премии РТ в области науки и техники, e-mail: sozinov@kgmu.kcn.ru 


\section{Иностранные члены редколлегии}

Адольфо Балойра, проф. респираторной медицины госпиталя Понтеведра, координатор отделения генетики и легочной гипертензии университета Виго, врач-пульмонолог, Испания, e-mail: adolfo.baloira.villar@sergas.es;

Жилберт Массард, Страсбургский университет, Франция, e-mail: Gilbert.Massard@chru-strasbourg.fr; Карл-Дитер Хеллер, Клиника им. Герцогини Элизабет, Брауншвейг, Германия, e-mail: KD.Heller@hen-bs.de;

Мажид Садих, проф. внутренних болезней Госпиталя Св. Марии Уотербери, шт. Коннектикут (клиника Йельского университета), Йель, США, e-mail: majid.sadigh@yale.edu;

Мелих Эльчин, Университет Хачеттепе, Турция, e-mail: melcin@hacettepe.edu.tr; Тили Тансей, Лондонский университет королевы Марии, Великобритания, e-mail: t.tansey@gmul.ac.uk;

Франтишек Выскочил, доктор наук, проф., член ученого общества CZ, Физиологического общества, Кембридж, Лондон, Институт физиологии AVCR, факультет естественных наук

Карлова университета, Прага, Чехия, e-mail: vyskocil@biomed.cas.cz

\section{Редакционный совет}

Абдулхаков Сайяр Рустамович, к.м.н., зам. директора Института фундаментальной медицины и биологии КФУ (Казань), e-mail: sayarabdul@yandex.ru;

Анохин Владимир Алексеевич, д.м.н., проф., зав. кафедрой детских инфекций ГБОУ ВПО КГМУ (Казань), e-mail: anokhin56@mail.ru;

Галеева Зарина Мунировна, К.М.н., доцент кафедры терапии ГБОУ ДПО КГМА, проф. PAE (Казань), e-mail: zarina26@bk.ru;

Жестков Александр Викторович, д.м.н., проф. зав. кафедрой микробиологии, иммунологии и аллергологии ГБОУ ВПО СамГМУ (Самара), e-mail: zhestkovav@yandex.ru; Жиляев Евгений Валерьевич, д.м.н., проф. кафедры ревматологии ГБОУ ДПО РМАПО, гл. врач ЗАО «Юропиан медикал сентер» (Москва), e-mail: zhilyayevev@mtu-net.ru;

Загидуллин Шамиль Зарифович, д.м.н., проф., зав. кафедрой пропедевтики внутренних болезней ГБОУ ВПО БГМУ (Уфа), e-mail: zshamil@inbox.ru;

Зыятдинов Камиль Шагарович, д.м.н., проф., ректор ГБОУ ДПО КГМА (Казань), e-mail: ksma@mi.ru;

Маянская Светлана Дмитриевна, д.м.Н., проф., проректор ГБОУ ВПО КГМУ по науке и инновациям (Казань), e-mail: smayanskaya@mail.ru;

Миллер Ольга Николаевна, д.м.н., проф. кафедры неотложной терапии ФПК и ППв ГБОУ ВПО НГМУ (Новосибирск), e-mail: miller@online.nsk.su;

Потапова Марина Вадимовна, к.М.Н., проф. РАЕ, гл. врач Городской детской клинической больницы № 1, заслуженный врач РТ (Казань), e-mail: kaz_gdb1@mail.ru; Сабиров Ленар Фарахутдинович, к.м.Н., ассистент кафедры общественного здоровья, экономики и организации здравоохранения ГБОУ ДПО КГМА, начальник Клинического госпиталя МСЧ МВД России по РТ (Казань), e-mail: hospitalmvdrt@rambler.ru;

Сафина Асия Ильдусовна, д.м.н., проф., зав. кафедрой педиатрии ГБОУ ДПО КГМА (Казань), e-mail: safina_asia@mail.ru;

Сигитова Ольга Николаевна, Д.М.Н., проф., зав. кафедрой ОВП ГБОУ ВПО КГМУ, заслуженный врач РТ и РФ (Казань), e-mail: osigit@rambler.ru;

Тухбатуллина Рузалия Габдулхаковна, д.ф.н., зав. кафедрой фармацевтической технологии ГБОУ ВПО КГМУ (Казань), e-mail: ruzaliyatuhbatullina@mail.ru;

Шубин Игорь Владимирович, к.м.Н., проФ. РАЕ, гл. терапевт Военно-медицинского управления ГКВВ МВД России, полковник медицинской службы, заслуженный врач РФ (Москва), e-mail: shubin-igor@mail.ru 
Reviewed and abstracted scientific-practical journal

Published since 2008

Is issued 6 times a year + supplements

\section{CONSTITUTORS}

Multiprofile Medical Centre "Contemporary clinical medicine» Ltd with participation SBEI of HPE «Kazan State Medical University» of HM of RF

Journal is registered

by Federal Service on Supervision in the Sphere of Communication,

Informational Technologies and Mass

Communications (Roskomnadzor).

Certificate ПИ № ФС 77-41624 of 11.08 .2010

Reregistered 26.04.2013

Certificate ПИ № ФС 77-53842

The languages: russian and english

Subscription index of the journal in the

«Pressa Rossii» catalogue is 41628

Catalogue of Kazakhstan is 41628

Editorial office and publishers address: Tatarstan Republic, 420043 Kazan, Vishnevsky str., 57-83 Contacts:

(843)291-26-76, (843)277-88-84 (fax) e-mail: vskmjournal@gmail.com

Marketing department

Tel. +7-903-307-99-47

Contact person -

chief Renata Amirova e-mail: renata1980@mail.ru

Accessible on sites:

http://www.vskmjournal.org, www.kgmu.kcn.ru, www.elibrary.ru, cyberleninka.ru, www.es.rae.ru/vskm, twitter.com/vskmjournal

Editorial board of the journal may disagree with authors' point of view on one or another of the problems

The manuscripts are not given back, any copy without editorial board's agreement is not allowed. Advertiser is on the responsibility for publicity's content. All medicines, articles of medical purpose and medical equipment, mentioned in this publication, have registration certificates.

Computer support,

site of journal and web version:

Rustem Shaymuratov

e-mail: russtem@gmail.com

Edited by authors. Cover's designer -

C.F. Safarova. Technical editing -

Yu.R.Valiakhmetova. Page make-up -

T.D.Torsueva. Proofreader - N.A. Petrova

Format $60 \times 84 \frac{1}{8}$. Signed for publication 13.02.15.

Conventional printer's sheet 11,63 .

Circulation - 3000 copies. Order 15-2

$$
\text { Free price }
$$

Original make-up page is made by the publishing house "Medicina» of SAl «RMLC»

420059 Kazan, Khady Taktash St., 125.

Printed by the department of operative polygraphy of SAl «RMLIC».

420059 Kazan, Khady Taktash St., 125

(C) Multiprofile Medical Centre

«Contemporary clinical medicine» Ltd, 2015

(c) KSMU, 2015

\section{THE BULLETIN OF CONTEMPORARY CLINICAL MEDICINE}

\author{
SCIENTIFIC-PRACTICAL JOURNAL
}

\section{Volume 8, issue 12015}

\section{EDITORIAL BOARD \\ Editor in chief}

Nail B. Amirov, D.M., Prof. of general medicine practice department of SBEI HPE KSMU, Honored Science and Education Worker, Mem. of RANH, TR Honored Doctor, State Honoree of TR in Science and Technics, e-mail: namirov@mail.ru

\section{Deputy Editor in chief}

Alexander A. Vizel, D.M., Prof., head of Phthisiopulmonology Sub-faculty of SBEI HPE KSMU, Mem. of AS RG, Honored Doctor of TR, State Honoree of TR in Science and Technics,

e-mail: lordara@mail.ru

\section{Responsible Secretary}

Elena V. Khazova, C.M.Sci., teaching assistant of Internal Medicine Propaedeutics of SBEI HPE KSMU, e-mail: hazova_elena@mail.ru

\section{Editorial Board Members}

Valery Ju. Albitsky, D.M., Prof., Honored Science Worker of RF, State Honoree of RF Government in Science and Technics, head of Social Pediatrics Department of RAMS (Moscow), e-mail: albicky@nczd.ru;

Nail Kh. Amirov, D.M., Prof. of Occupational Medicine Sub-faculty of SBEI HPE KSMU, Mem. of RAMS, e-mail: amirovn@yandex.ru;

Andrey Ju. Anisimov, D.M., Prof. of Emergency Care, Disaster Medicine and Mobilization Training Sub-faculty of SBEI APE KSMA, e-mail: aanisimovbsmp@yandex.ru;

Albert S. Galyavich, D.M., Prof., head of Faculty Therapy Sub-faculty of SBEI HPE KSMU, Corresponding Member of TR AS, vice-president of RSSC, Honored Doctor of TR and RF, e-mail: agalyavich@mail.ru;

Airat U. Ziganshin, D.M., Prof., head of Pharmacology Sub-Faculty, vice-principal of SBEI HPE KSMU in international activity, State Honoree of TR in Science and Technics, e-mail: auziganshin@gmail.com;

Andrey P. Kiyasov, D.M., Prof., director of Fundamental Medicine and Biology Institute of KSU, Corresponding Member of TR AS, e-mail: APKiyasov@ksu.ru;

Vladimir D. Mendelevich, D.M., Prof., head of Medical and General Psychology Sub-faculty of SBEI HPE KSMU, e-mail: mend@tbit.ru;

Evgenii E. Nickolsky, head of Medical and Biological Physics with Informatics and Medical Apparatus of SBEI HPE KSMU,

Mem. of RAMS in Physiology and Fundamental Medicine Department, vice-president of KazSC of RAMS in research; e-mail: eenik1947@mail.ru;

Alexey S. Sozinov, D.M., Prof., rector of SBEI HPE KSMU, State Honoree of TR in Science and Technics, e-mail: sozinov@kgmu.kcn.ru 


\section{Foreign Members of Editorial Board}

Adolfo Baloira, Prof. of Respiratory Medicine of Pontevedra Hospital, coordinator of Genetic and Pulmonary Hypertension department of Vigo University, lung specialist, Spain,

e-mail: adolfo.baliora.villar@sergas.es;

Gilbert Massard, Strasburg University, France, e-mail: Gilbert.Massard@chru-strasbourg.fr; Karl-Dieter Heller, Duchess Elizabeth Clinic, Braunschweig, Germany, e-mail: KD.Heller@hen-bs.de;

Majid SadiKh, Prof. Internal Diseases unit of St. Mary Waterbury Hospital, Connecticut (Yale University Clinic), Yale, USA, e-mail: majid.sadigh@yale.edu;

MeliKh ElcHin, Hacettepe University, Turkey, e-mail: melcin@hacettepe.edu.tr;

Tily Tansey, Queen Mary London University, Great Britain, e-mail: t.tansey@gmul.ac.uk;

Frantishek VyskocHil, D.M., Prof., CZ Physiologic fellow, Cambridge, London, Physiologic Institute AVCR, Natural Science Faculty of Karl University, Prague, Czech Republic, e-mail:vyskocil@biomed.cas.cz

\section{Editorial team}

Sayar R. Abdulkhakov, D.M., deputy director of Fundamental Medicine and Biology Institute of KFU (Kazan), e-mail: sayarabdul@yandex.ru;

Vladimir A. Anokhin, D.M., Prof., head of Children's Infection Sub-faculty of SBEI HPE KSMU (Kazan), e-mail: anokhin56@mail.ru;

Zarina M. Galeeva, C.M.Sci., Senior lecturer of Therapy Sub-faculty of SBEI APE KSMA, Prof. of RANS (Kazan), e-mail: zarina26@bk.ru;

Alexander V. Zhestkov, D.M., Prof., head of Microbiology, Immunology and Allergology Sub-faculty of SEI HPE «SamaraSMU» of RF HM (Samara), e-mail: zhestkovav@yandex.ru; Evgenii V. Zhilyayev, D.M., Prof. of Rheumatology Sub-faculty of SBEI APE RMAPE, head physician of CJSC «European Medical Center»(Moscow), e-mail: zhilyayevev@mtu-net.ru;

Shamil Z. Zagidullin, D.M., Prof., head of Propedeutics of Inner Diseases Sub-faculty of SBEI HPE BSMU (Ufa), e-mail: zshamil@inbox.ru;

Kamil Sh. Ziyatdinov, D.M., Prof., principal of SBEl APE KSMA (Kazan), e-mail: ksma@mi.ru; Svetlana D. Mayanskaya, D.M., Prof., vice-principal of SBEI HPE KSMU in science and innovations (Kazan), e-mail: smayanskaya@mail.ru;

Olga N. Miller, D.M., Prof. of Emergency Therapy Sub-faculty of IPSD and PRD of SBEI HPE NSMU (Novosibirsk); e-mail: miller@online.nsk.su;

Marina V. Potapova, C.M.Sci., Prof. of RANS, head physician of Municipal Children’s Hospital № 1, Honored Doctor of TR (Kazan), e-mail: kaz gdb1@mail.ru;

Lenar F. Sabirov, C.M.Sci., teaching assistant of Public health, Economics and Healthcare organization Sub-faculty of SBEI APE KSMA, chief of Clinical Hospital of MSU MIA of RF in TR (Kazan), e-mail: hospitalmvdrt@rambler.ru;

Asiaya I. Safina, Prof., head of Pediatry Sub-faculty of SBEI APE KSMA (Kazan), e-mail: safina_asia@mail.ru;

Olga N. Sigitova, D.M., Prof., head of General Practice Sub-faculty of SBEI HPE KSMU, Honored Doctor of TR and RF (Kazan), e-mail: osigit@rambler.ru;

Ruzaliya G.Tukhbatullina, D. Ph.Sci., head of Pharmaceutical Chemistry Sub-faculty of SBEI HPE KSMU (Kazan), e-mail: ruzaliyatukhbatullina@mail.ru;

Igor V. Shubin, D.M., chief physician of Military Medical Department of MIA of Russia, colonel of med. Service, Honored Doctor of RF, Prof. of RAMS (Moscow), e-mail: shubin-igor@mail.ru 


\section{СОДЕРЖАНИЕ}

\section{ОРИГИНАЛЬНЫЕ ИССЛЕДОВАНИЯ}

Влияние комплексной терапии с иммуномодулятором «Имунофан» на качество жизни больных микробной экземой. Н.А. Абдрахимова, 3.Р.Хисматуллина, Р.М. Надырченко, Е.М. Гареев, Г.Р. Мустафина

Многолетняя динамика и структура профессиональной заболеваемости в Республике Татарстан.

3.М. Берхеева, А.М. Гиниятова. ... 10

Организация врачебной помощи при болезнях плевры. А.А. Варин, А.Л. Ханин, Ю.Б. Развозжаев, Н.В. Чистякова

Туберкулезные эмпиемы плевры как предиктор летального исхода у больных туберкулезом легких. А.А. Варин, А.Л. Ханин, В.А. Фенстер ...23

Сравнительная оценка сердечно-сосудистого риска при артериальной гипертензии и коморбидной патологии. Г.А. Мухетдинова, З.P. Вахитова, Р.М. Фазлыева, Л.А. Ибрагимова .......27 Факторы риска развития инфицирования микобактериями туберкулеза детей, проживающих в сельской местности. Т.Г. Подкопаева, А.A. Tyрица, Е.С. Леонтьева, Г.Ж. Сагалбаева,

П.Н. Герасимов

Возможности кардиопульмонального нагрузочного тестирования в оценке физической работоспособности и функционального состояния дыхательной системы у здоровых лиц. Л.Б. Постникова, И.А. Доровской, В.А. Костров, И.В. Долбин, А.А. Федоренко

Эффективность противомикробных препаратов в лечении обратимых пульпитов биологическим методом. Г.Р. Рувинская, Ю.В. Фазылова ........442

Диагностические возможности теста активации базофилов в выявлении сенсибилизации к ядам перепончатокрылых насекомых. Л.Ф. Сафина, Р.С. Фассахов, Е.В. Агафонова.
Внелегочный туберкулез у детей за 20-летний период наблюдения. А.А. Турица, Н.И. Поркулевич, Е.А. Цыганкова

Опыт лечения эрозивных толстокишечных кровотечений. И.М. Фатхутдинов 54

\section{ОБМЕН ОПЫТОМ}

Оценка эффективности гемостатического действияпрепарата «Гемоблок» при полостных и лапароскопических вмешательствах. Мультицентровые клинические исследования. А.В. Плоткин, Е.Ж. Покровский, Г.В. Воронова, К.А. Менглет.

\section{ОБЗОРЫ}

Хроническая обструктивная болезнь легких (ХОБЛ). Перемены как повод для обсуждения.

А.А. Визель, И.Ю. Визель, Н.Б. Амиров . 62 Когнитивные нарушения при хронической сердечной недостаточности. Г. С. Галяутдинов, М.А. Лонкин

\section{ОРГАНИЗАЦИЯ ЗДРАВООХРАНЕНИЯ}

Использование технологии риск-менеджмента для повышения эффективности первичной профилактики инфаркта миокарда. А.М. Назаров ....78 Прошлое и настоящее профпатологической службы в Республике Татарстан. С.А. Осипов, И.Ю. Малышева, 3.М. Берхеева.

Экономическая эффективность применения лазерных технологий в условиях хирургического стационара с краткосрочным пребыванием пациентов. С.В. Шахрай, Ю.М. Гаин, Ю.Ю. Полумисков, М.Ю. Гаин, В.В. Груша

Правила оформления статей и тезисов для авторов в журнал и приложения «Вестник современной клинической медицины» ISSN 2071-0240 (Print), issn 2079-553x (on line) 


\section{ORIGINAL STUDIES}

The impact of a complex therapy with immunomodulator «imunofan» on quality of life of patients with microbial eczema. N.A. Abdrakhimova,

\section{Z.R. Khismatullina, R.M. Nadyrchenko,}

\section{E.M. Gareev, G.R. Mustafina}

Long-term dynamics and structure of occupational diseases in Republic of Tatarstan. Z.M. Berkheeva,

A.M. Giniyatova

Organization of medical care in pleural diseases.

A.A. Varin, A.L. Khanin, Y.B. Razvozzhaev,

N.V. Chistykova 18

Tuberculous empyema of pleura as a predictor of death in patients with pulmonary tuberculosis.

A.A. Varin, A.L. Khanin, V.A. Fenster.

Comparative assessment of cardiovascular risk for arterial hypertension and comorbid pathology. G.A. Mukhetdinova, Z.R. Vakhitova, R.M. Fazliyeva, L.A. Ibragimova ....27

Risk factors of mycobacterium tuberculosis infection in children living in rural areas. T.G. Podkopaeva, A.A. Turitsa, E.S. Leontieva, G.Zh. Sagalbaeva, P.N. Gerasimov.

A capability of cardiopulmonary exercise testing in the assessment of physical health and functional condition of respiratory system in healthy persons.

L.B. Postnikova, I.A. Dorovskoy, V.A. Kostrov, I.V. Dolbin, A.A. Fedorenko

Efficiency of antimicrobic treatement in treatment of reversible pulpitises by the biological method.

G.R. Ruvinskaya, J.V. Fazylova. .... 42

Possibilities of basophil activation test in diagnostic of hymenoptera sensitization. L.F. Safina, R.S. Fassakhov, E.V. Agafonova

Extrapulmonary tuberculosis in children: the 20-year observation. A.A. Turitsa, N.I. Porkulevich,

E.A. Tsygankova 50

Experience of erosive colonic bleeding treatment.

I.M. Fatkhutdinov.

7

\section{EXCHANGE OF EXPERIENCE}

The evaluation of the effectivity of hemostatic activity of Haemoblock for local topical use Haemoblock in different surgical situations. Multicenter clinical trials. A.V. Plotkin, E.Zh. Pokrovskij, G.V. Voronova, K.A. Menglet.

\section{REVIEWS}

Chronic obstructive pulmonary disease (COPD). Changes as a cause for discussion. A.A. Vizel, I. Yu. Vizel, N.B. Amirov 62 Cognitive impairment in chronic heart failure. G.S. Galjautdinov, M.A. Lonkin

\section{ORGANIZATION OF HEALTHCARE}

Applying risk-management technology for effectivization the primary prevention of myocardial infarction. A.M. Nazarov.

Occupational pathology services in tatarstan: past and present. S.A. Osipov, I.Yu. Malysheva, Z.M. Berkheeva

Economic efficiency of laser technologies using in surgical hospital of short-term stay. S.V. Shakhray, Yu.M. Gain, Yu.Yu. Polumiskov, M.Yu. Gain, V. V. Grusha

The bulletin of contemporary clinical medicine ISSN 2071-0240 (Print), issn 2079-553x (on line) The rules for articles registration for authors. 


\section{ВЛИЯНИЕ КОМПЛЕКСНОЙ ТЕРАПИИ С ИММУНОМОДУЛЯТОРОМ «ИМУНОФАН" НА КАЧЕСТВО ЖИЗНИ БОЛЬНЫХ МИКРОБНОЙ ЭКЗЕМОЙ}

НАДЕЖДА АЛЕКСЕЕВНА АБДРАХИМОВА, врач-ДерМаТОВеНероЛоГ ГАУЗ РКВД, УФа, РОссия, теЛ. 8-962-527-98-34, e-mail: brenda160485@mail.ru

ЗАРЕМА РИМОВНА ХИСМАТУЛЛИНА, докт. мед. наук, профессор, зав. кафедрой дерматовенерологии с курсами дерматовенерологии и косметологии ИПО «Башкирский государственный медицинский университет» Минздрава России, Уфа, Россия, тел. 8-987-255-43-01, e-mail: hzr07@mail.ru

РОБЕРТ МАРАТОВИЧ НАДЫРЧЕНКО, Зав. КЛИНИКО-ДИаГНОстической лабораторией ГАУЗ РКВД, Уфа, Россия, тел. 8-927-323-02-62, e-mail: nadirob@ list.ru

ЕВГЕНИЙ МУСИНОВИЧ ГАРЕЕВ, канд. бИол. наук, доцент, старший научный сотрудник Всероссийского центра глазной и пластической хирургии, Уфа, Россия, тел. 8-927-351-01-86, e-mail: gem46@list.ru

ГУЛЬГИНА РАИСОВНА МУСТАФИНА, канд. мед. наук, ассистент кафедры дерматовенерологии с курсами дерматовенерологии и косметологии ИПО «Башкирский государственный медицинский университет» Минздрава России, Уфа, Россия, тел. 8-917-430-76-73, e-mail: gulginar@rambler.ru

Реферат. Цель исследования - изучить влияние комплексной терапии с препаратом «Имунофан» на качество жизни больных микробной экземой. Материал и методы. Больные были разделены на 2 группы: 1-ю группу составили 80 человек - 50 женщин $(62,5 \%)$ и 30 мужчин (37,5\%) в возрасте 35—56 лет, которые на фроне традиционной терапии применяли имунофран в виде ректальных суппозиториев по 100 мкг 1 раз в день в течение 25 дней; 2-ю группу наблюдения составили 104 больных - 62 женщины (59,6\%) и 42 мужчины (40,4\%) в возрасте 35-56 лет с микробной экземой, которые получали только традиционное лечение (гипосенсибилизирующие препараты, антибактериальные средства, витамины, корректоры микроциркуляции). Для оценки качества жизни использовали опросник «Дерматологический индекс качества жизни» - ДИКЖ (Dermatology Life Quality Index DLQI), состоящий из 10 пунктов и включающий оценочные показатели от 0 до 3 баллов с максимальной суммой 30 баллов (качество жизни пациента обратно пропорционально сумме баллов). Цифровой показатель, который получают в результате анализа ответов пациента, отражает уровень негативного воздействия заболевания на качество жизни пациента. Индекс ДИКЖ может использоваться как критерий оценки эффективности лечения дерматологического заболевания. Результаты и их обсуждение. По окончании лечения в группе с традиционным лечением существенных изменений не произошло - оценки качества жизни сместились в область четвертой категории (смена «чрезмерно сильного» влияния на просто «сильное»). А в группе, где использовался имунофан, к концу лечения для 47\% больных влияние микробной экземы на различные аспекты их жизни стало «умеренным», еще для 47\% - «незначительным», а в 6\% случаев заболевание вообще не влияло на жизнь пациента. Заключение. Применение комплексной терапии с препаратом «Имунофан» характеризуется постепенным восстановлением качества жизни больных микробной экземой.

Ключевые слова: микробная экзема, иммуномодулятор «Имунофан», дерматологический индекс качества жизни (ДИКЖ).

\section{THE IMPACT OF A COMPLEX THERAPY WITH IMMUNOMODULATOR «IMUNOFAN" ON QUALITY OF LIFE OF PATIENTS WITH MICROBIAL ECZEMA}

NADEZHDA A. ABDRAKHIMOVA, dermatologist, State Independent Healthcare Institution Republican Dermatovenerologic Dispensary, Ufa, Russia, tel. 8-962-527-98-34, e-mail: brenda160485@mail.ru

ZAREMA R. KHISMATULLINA, M.D., Professor, Head of the Department of dermatology with the course of dermatology and cosmetology of the Institute of Professional Training at the Bashkir State Medical University, Ufa, Russia, tel. 8-987-255-43-01, e-mail: hzr07@mail.ru

ROBERT M. NADYRCHENKO, Head of the Clinical and Diagnostic laboratory of the State Independent Healthcare Institution Republican Dermatovenerologic Dispensary, Ufa, Russia, tel. 8-927-323-02-62, e-mail: nadirob@ list.ru EVGENIY M. GAREEV, Ph.D., associate professor, Senior research fellow of the All-Russian center of eye and plastic surgery, Ufa, Russia, tel. 8-927-351-01-86, e-mail: gem46@list.ru

GULGINA R. MUSTAFINA, Ph.D., assistant of Department of dermatology with the course of dermatology and cosmetology of the institute of Professional Training at the Bashkir State Medical University, Ufa, Russia, tel. 8-917-430-76-73, e-mail: gulgenar@rambler.ru

Abstract. Aim. The aim of the research was to study the influence of a complex therapy with immunomodulator «Imunofan» on quality of life of patients with microbial eczema. Material and methods. The patients were divided into 2 groups: the 1 group included 80 patients -50 women $(62,5 \%)$ and 30 men $(37,5 \%)$ aged $35-56$ who, along with 
traditional therapy, were administered imunofan in the form of rectal suppositories $100 \mathrm{mkg}$ once a day for 25 days; the 2 group consisted of 104 patients (62 women (59,6\%) and 42 men (40,4\%) aged 35-56) with microbial eczema receiving only traditional treatment (hyposensibilitive and antibacterial medicines, vitamins, microcirculation correctors). To assess quality of life the Dermatology Life Quality Index (DLQI) was used. It is a 10-question validated questionnaire where the total score is calculated by summing the score of all items, resulting in a maximum score of 30 and a minimum score of 0 (patient's quality of life is inversely proportional to the total score). The numeral value obtained after analyzing the patient's answers indicates the level of negative influence of the disease on patient's quality of life. DLQI may be used as a criterion for health-related quality of life measure for a dermatological disease. Results and discussion. After the treatment, the group of patients receiving traditional therapy showed no substantial changes - the assessment of quality of life shifted to the area of 4 category (change from «extremely large effect on patient's life» to «very large effect on patient's life»). $47 \%$ of patients in the group used imunofan at the end of treatment assessed the impact of microbial eczema on their quality of life as «moderate», $47 \%$ - as «small» and $6 \%$ noticed no effect of the disease on their life. Conclusions. The use of a complex therapy with Imunofan is characterized by gradual restoration of quality of life of patients with microbial eczema.

Key words: microbial eczema, immunomodulator «Imunofan», Dermatology Life Quality Index (DLQI).

$\mathrm{M}$ икробная экзема относится к категории полиэтилогических аллергодерматозов, характеризующихся рефрактерностью ко многим терапевтическим воздействиям [2, 3]. По результатам эпидемиологических исследований различные виды микробной экземы являются самыми частыми заболеваниями в практике врача-дерматовенеролога (от 9 до 35\%), которые чаще всего регистрируются у женщин среднего возраста и у работников, имеющих профессиональный контакт с пищевыми продуктами или химическими соединениями [8]. Больные микробной экземой, для которой характерно длительное течение с частыми рецидивами, составляют 20-30\% дерматологических пациентов. Среди всех случаев патологии кожи, по поводу которых больные направляются в стационар, приблизительно 10\% приходится на микробную экзему [4].

Заболеваемость экземой среди трудоспособного населения составляет от 2 до 10\%, что не только значительно отражается на качестве жизни пациентов, но и существенно влияет на экономический потенциал семьи и общества [7, 9].

В развитых странах отмечается постоянный рост числа пациентов с микробной экземой, связанный с ухудшением экологической обстановки, а также постоянно ускоряющимся ритмом жизни, приводящим к стрессам и хронической усталости [6]. В данных условиях становится очевидной необходимость повышения защитных сил макроорганизма.

Имунофан синтезирован на основе естественного пептидного гормона иммунитета вилочковой железы тимопоэтина II и содержит в качестве активной фрармакологической субстанции гидрофильный гексапептид. Результаты клинических испытаний показали, что применение имунофана позволяет без дополнительной антигенной нагрузки и аллергизации организма достичь высокого уровня продукции специфических антител, а также приводит к усилению способности клеток к завершенному фагоцитозу [5].

Цель исследования - изучить влияния комплексной терапии с препаратом «Имунофан» на качество жизни больных микробной экземой.

Материал и методы. Для изучения влияния комплексной терапии имунофаном на качество жизни больные были разделены на 2 группы: 1-ю группу составили 80 человек - 50 женщин $(62,5 \%)$ и 30 мужчин $(37,5 \%)$ в возрасте 35-56 лет, которые на фоне традиционной терапии применяли имунофан в виде ректальных суппозиториев по 100 мкг 1 раз в день в течение 25 дней; 2-ю группу наблюдения составили 104 больных - 62 женщины $(59,6 \%)$ и 42 мужчины $(40,4 \%)$ в возрасте 35-56 лет с микробной экземой, которые получали только традиционное лечение (гипосенсибилизирующие препараты, антибактериальные средства, витамины, корректоры микроциркуляции). У 76,1\% больных микробная экзема имела длительное торпидное течение с многократными обострениями. Средняя продолжительность заболевания составила $(12,3 \pm 6,3)$ года. У всех пациентов была диагностирована стадия обострения микробной экземы. Клиническая картина дерматоза являлась типичной.

Все больные получали базовое лечение в дерматологическом отделении № 1 ГАУЗ РКВД г. Уфы в соответствии со стандартами, утвержденными приказами Министерства здравоохранения и социального развития Российской Федерации от 30.05.2006 № 433, 11.12.2007 № 746 и 18.12.2007 № 773 .

Для оценки качества жизни использовали опросник «Дерматологический индекс качества жизни» ДИКЖ (Dermatologi Life Qualiti Index - DLQI), coстоящий из 10 пунктов и включающий оценочные показатели от 0 до 3 баллов с максимальной суммой 30 баллов (качество жизни пациента обратно пропорционально сумме баллов). Индекс был разработан специалистами Уэльского университета. Анкета для определения индекса ДИКЖ предназначена для пациентов старше 16 лет. Вопросы анкеты адресованы непосредственно пациенту, поэтому отвечать на них должен он сам. К достоинствам анкеты можно отнести простоту (ее могут заполнять больные разного возраста и интеллектуального уровня) и возможность заполнить за $1-3$ мин. Качество жизни оценивалось по шести основным параметрам: 1-й и 2-й вопросы - симптомы/самочувствие, 3-й и 4-й - ежедневная активность, 5-й и 6-й - досуг, 7-й - работа/учеба, 8-й и 9-й - личные отношения, 10-й - лечение. Цифровой показатель, который получают в результате анализа ответов пациента, отражает уровень негативного воздействия заболевания на качество жизни пациента. Индекс ДИКЖ может использоваться как критерий оценки эффрективности лечения дерматологического заболевания [1].

ДИКЖ рассчитывался по 10 четырехступенчатым шкалам, касающимся влияния микробной экземы на 
различные аспекты жизни и деятельности больных микробной экземой. По каждой шкале пациент мог ответить либо «нет, не влияет» (числовой эквивалент - 0 баллов), либо «влияет незначительным образом» (1 балл), либо «влияет достаточно сильно» (2 балла), либо «влияет очень сильно» (3 балла). При обработке опросника ДИКЖ для каждого пациента баллы по всем 10 шкалам суммировались. Полученную сумму относили к одной из пяти градаций (категорий): 0-1 балл - «не влияет» (I); 2-5 баллов - «незначительно влияет» (II); 6-10 баллов «умеренно влияет» (III); 11-20 баллов - «сильно влияет» (IV); 21-30 баллов - «чрезвычайно сильно влияет» (V). Заполнение анкет больные двух наблюдаемых групп проводили трижды: до лечения, через 10 дней с начала лечения и после лечения (при выписке).

Результаты и их обсуждение. Частота встречаемости каждой из этих пяти категорий в обеих группах по всем трем этапам наблюдений представлена на рисунке.

Как видно из рисунка, до начала лечения все без исключения пациенты обеих групп считали, что микробная экзема влияет на их состояние и жизненный уклад «чрезвычайно сильно» (пятая категория). Через 10 дней после начала лечения в группе с традицион- ным лечением оценки влияния микробной экземы на качество жизни остались такими же, как и до начала лечения, а в группе, где использовался имунофан, оценки всех пациентов сместились в область четвертой категории, что свидетельствует о некотором улучшении их состояния (влияние «сильное», но уже не «чрезвычайно сильное»). По окончании лечения в оценках пациентов в группах с разным способом лечения возникли принципиальные различия. В группе с традиционным лечением существенных изменений не произошло - оценки качества жизни сместились в область четвертой категории (смена «чрезмерно сильного» влияния на просто «сильное»). В группе, где использовался имунофран, состояние пациентов изменилось кардинальным образом. Во-первых, никто из них уже не считал, что заболевание влияет на их жизнь «сильно» или «чрезвычайно сильно». Для 47\% больных данной группы влияние микробной экземы на различные аспекты их жизни стало «умеренным», еще для 47\% - «незначительным», а в $6 \%$ случаев заболевание вообще не влияло на жизнь пациента.

Выводы. Применение комплексной терапии с препаратом «Имунофан» характеризуется постепенным восстановлением качества жизни больных микробной экземой.

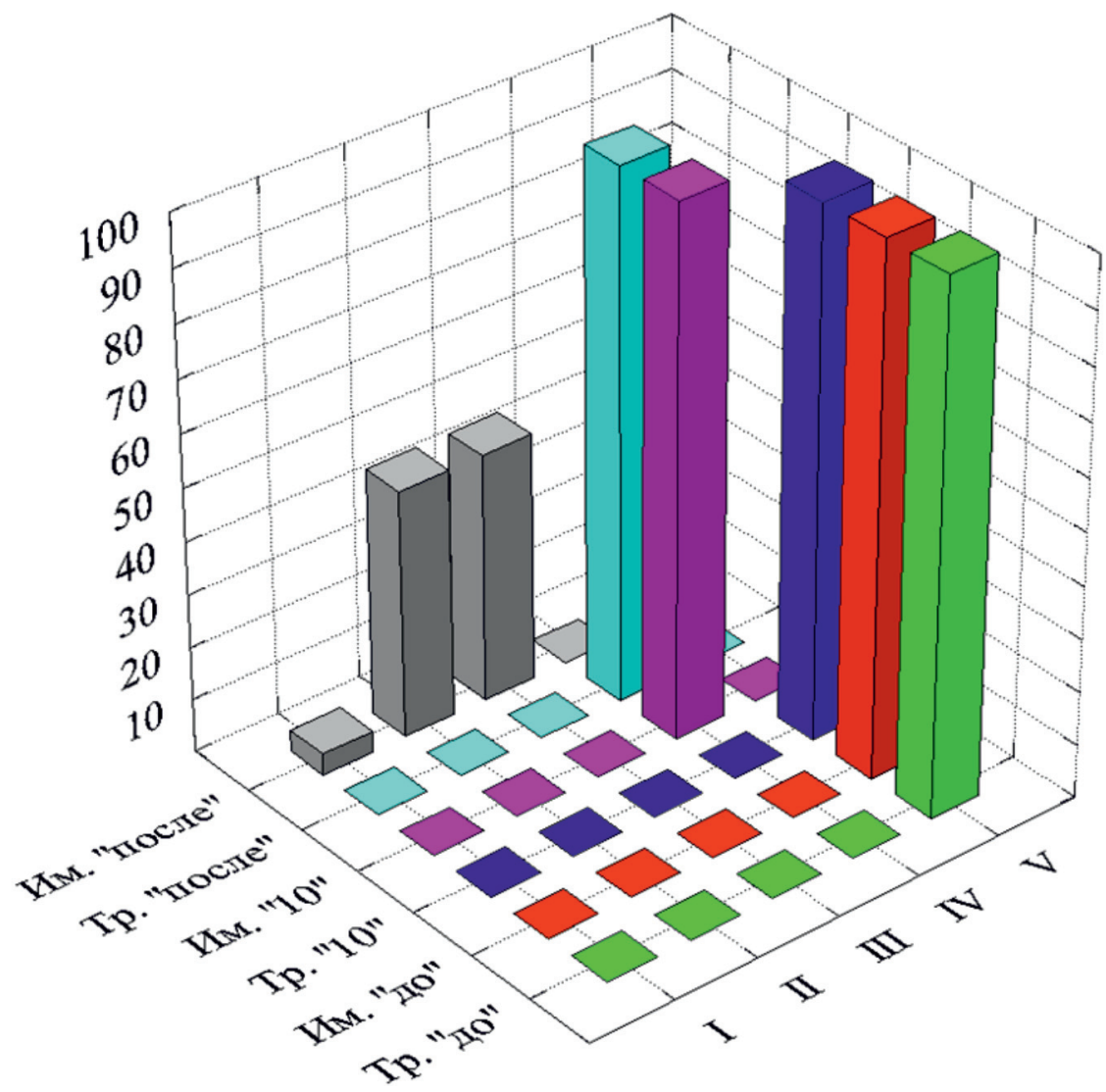

Трехмерная диаграмма, отображающая частоту встречаемости пяти категорий ДИКж в группе с традиционным лечением и лечением имунофаном на трех этапах наблюдения за пациентами.

Примечание: Тр. - лечение осуществлялось традиционными методами; Им. - осуществлялось лечение имунофраном. В кавычках индексы этапов наблюдения: «до» - до начала лечения, «10» - через 10 дней после начала лечения, «после» - после окончания лечения. Римскими цифрами указаны категории ДИкЖ. 


\section{ЛИТЕРАТУРА}

1. Адаскевич, В.П. Дерматологические индексы в дерматологии / В.П. Адаскевич. - М.: Медицинская книга, 2004. - C.165.

2. Белоусова, Т.А. Аллергодерматозы - болезни современной цивилизации / Т.А. Белоусова // Российский медицинский журнал. - 2004. - Т. 11, № 27. С.1538-1542.

3. Иванова, В.Л. Кожные и венерические болезни: справочник / В.Л. Иванова. - М.: Медицина, 2007. C.315-320.

4. Львов, А.Н. Современная диагностика аллергического контактного дерматита: возможности и перспективы / А.Н. Львов, О.Л. Иванов, С.С. Белоусова, С.С. Полунина // Российский журнал кожно-венерологических болезней. - 2007. — № 3. - С.17-22.

5. Покровский, В.И. Имунофран. Опыт применения в клинической практике / В.И. Покровский. - М., 2010. - С.1-2.

6. Потекаев, Н.С. Экзема: ремарки и современные представления / Н.С. Потекаев // Клиническая дерматовенерология. - 2009. - № 1. - С.67-73.

7. Qualiti of life and depression in a population of occupational hand eczemapatients / R.S. Cvetkovski, R. Zachariae, H. Jensen [et al.] // Contact Dermatitis. - 2006. Vol. 54. - P.21-22.

8. Hend dermatitis / D.M. Elston, K.L. Watsky, K. Schwarzenberger [et al.] // J. Am. Acad. Dermatol. — 2002. Vol. 47. - P.292-299.

9. Impact of chronic hand dermatitis on quality of life, work productivity, activity impairment and medical costs / J.F. Fovler, A. Ghosh, S. Sung [et al.] // J. Am. Acad. Dermatol. - 2006. - Vol. 54. - P.448-457.

\section{REFERENCES}

1. Adaskevich, V.P. Dermatologicheskie indeksy v dermatologii [Dermatological indices in dermatology] / V.P. Adaskevich. - M.: Medicinskaya kniga, 2004. - S.165.
2. Belousova, T.A. Allergodermatozy - bolezni sovremennoi civilizacii [Allergic dermatoses - diseases of modern civilization] / T.A. Belousova // Rossiiskii medicinskii zhurnal [Russian Medical Journal]. — 2004. - T. 11, № 27. - S.1538-1542.

3. Ivanova, V.L. Kozhnye i venericheskie bolezni [Skin and venereal diseases]: spravochnik / V.L. Ivanova. - M.: Medicina, 2007. - S.315-320.

4. L'vov, A.N. Sovremennaya diagnostika allergicheskogo kontaktnogo dermatita: vozmozhnosti i perspektivy [Modern diagnostics of allergic contact dermatitis: possibilities and prospects] / A.N. L'vov, O.L. Ivanov, S.S. Belousova, S.S. Polunina // Rossiiskii zhurnal kozhno-venerologicheskih boleznei [Russian journal of skin and venereal diseases]. - 2007. - № 3. S.17-22.

5. Pokrovskii, V.I. Imunofan. Opyt primeneniya v klinicheskoi praktike [Imunofan. Clinical practice experience] / V.I. Pokrovskii. - M., 2010. - S.1-2.

6. Potekaev, N.S. Ekzema: remarki i sovremennye predstavleniya [Eczema: remarks and modern ideas] / N.S. Potekaev // Klinicheskaya dermatovenerologiya. 2009. — № 1. - S.67-73.

7. Qualiti of life and depression in a population of occupational hand eczemapatients / R.S. Cvetkovski, R. Zachariae, H. Jensen [et al.] // Contact Dermatitis. - 2006. Vol. 54. - P.21-22.

8. Hend dermatitis / D.M. Elston, K.L. Watsky, K. Schwarzenberger [et al.] // J. Am. Acad. Dermatol. — 2002. Vol. 47. - P.292-299.

9. Impact of chronic hand dermatitis on quality of life, work productivity, activity impairment and medical costs / J.F. Fovler, A. Ghosh, S. Sung [et al.] // J. Am. Acad. Dermatol. — 2006. - Vol. 54. - P.448457.

Принята 16.09.2014

\section{МНОГОЛЕТНЯЯ ДИНАМИКА И СТРУКТУРА ПРОФЕССИОНАЛЬНОЙ ЗАБОЛЕВАЕМОСТИ В РЕСПУБЛИКЕ ТАТАРСТАН}

ЗУХРА МИНДИЯРОВНА БЕРХЕЕВА, канд. мед. наук, доцент кафедры гигиены, медицины труда ГБОУ ВПО «Казанский государственный медицинский университет» Минздрава России, Казань, Россия, тел. 8-905-310-74-46, e-mail: kgmu profpat@mail.ru

АЛСУ МУХАММАТОВНА ГИНИЯтОВА, Управление федеральной службы по надзору в сфере защиты прав потребителей и благополучия человека по Республике Татарстан, Казань, Россия, тел. 8-97-240-95-03, e-mail: rpn.trud@tatar.ru

Реферат. Целью работы явилось изучение динамики и структуры профессиональной заболеваемости в Республике Татарстан. Анализ выполнен на основе данных Республиканского регистра профессиональных заболеваний, Управления Роспотребнадзора по Республике Татарстан. Результаты. Профессиональная заболеваемость на протяжении последних 10 лет сохраняется в пределах 1,52-1,99 случаев на 10000 работающих в Российской Федерации и 1,16-1,87 - в Республике Татарстан. В структуре профессиональной патологии преобладают заболевания, обусловленные воздействием физических фракторов. Второе место составили болезни от воздействия промышленных аэрозолей, третье - заболевания, связанные с воздействием физических перегрузок, четвертое - острые и хронические интоксикации, пятое - инфекционные болезни. Заключение. Уровень зарегистрированной хронической профессиональной заболеваемости не отражает реальной ситуации, связанной с состоянием условий труда на производстве. Немаловажное значение имеет неудовлетворительное качество периодических медицинских осмотров и недовыявление больных с начальными признаками профзаболеваний. Нельзя не учитывать желание самого работника сохранить рабочее место, а следствием этого является поздняя экспертиза связи заболевания с профессией. Из числа зарегистрированных за последние 5 лет 20-30\% больных обратились за проспатологической экспертизой самостоятельно, а не в ходе периодического медосмотра. Большинство случаев профпатологий, выявленных при обращении работников за медицинской помощью, - хронические фрормы профессиональных заболеваний, которые, как правило, установлены работникам со стажем работы с вредным производственным фактором 20-39 лет (до 80\%) и возрастом свыше 50 лет (до 
70\%). Комплексное решение задач по охране здоровья работающих с учетом межведомственной координации системы мер позволит обеспечить сохранение трудового потенциала, продлить трудовое долголетие, снизить общую и профессиональную заболеваемость.

Ключевые слова: профпатологическая служба, профессиональная заболеваемость, периодические медицинские осмотры.

\title{
LONG-TERM DYNAMICS AND STRUCTURE OF OCCUPATIONAL DISEASES IN REPUBLIC OF TATARSTAN
}

\author{
ZUKHRA M. BERKHEEVA, Ph.D., associate professor of Department of hygiene and occupational health of SBEI HPE \\ «Kazan State Medical University» of Russian Ministry of Health, Kazan, Russia, tel. 8-905-310-74-46, \\ e-mail: kgmu_profpat@mail.ru \\ ALSU M. GINIYATOVA, Department of the Federal service for supervision of consumer rights protection \\ and human well-being in the Republic of Tatarstan, Kazan, Russia, tel. 8-97-240-95-03, e-mail: rpn.trud@tatar.ru
}

\begin{abstract}
The aim of the work was to study the dynamics and structure of occupational diseases in the Republic of Tatarstan. Analysis is made on the basis of the data of the national register of occupational diseases, the Epidemiology service of the Republic of Tatarstan. Results. Occupational morbidity over the past 10 years is stayed within 1,52-1,99 per 10000 working population in Russian Federation and 1,16-1,87 in the Republic of Tatarstan. Diseases caused by the influence of physical factors prevail in the structure of the pathology are. Diseases caused by industrial aerosols are on the second place followed by diseases associated with physical overload, acute and chronic intoxication and infectious diseases. Conclusion. The level of registered chronic occupational diseases does not reflect the real situation concerning working conditions. Poor quality of the periodic health examination and diagnostic patients with initial signs of occupational diseases also important. It is necessary to consider desire of the worker to keep his workplace and thereof late examination of communication of a disease with a profession. Among patients registered over the last 5 years $20-30 \%$ applied for professional pathological examination by themselves, not during periodic medical examination. The majority of the cases of professional pathology revealed at request of workers consisted of chronic forms of occupational diseases which are, as usual, were established at workers with 20-39 year experience with harmful production factor $(80 \%)$ and age over 50 years (to $70 \%)$. The complex health protection of working population with interdepartmental coordination will provide preservation of labor potential, extension of labor longevity, decrease general and professional incidence.
\end{abstract}

Key words: occupational service, occupational diseases, periodical medical examinations.

о данным Международной организации труда, ежегодно 2 млн 200 тыс. человек в мире умирают в результате несчастных случаев на работе или болезней, связанных с производством, 270 млн человек на рабочем месте получают разного рода травмы, 160 млн человек ежегодно получают профессиональные заболевания. В экономически развитых странах здоровье работника рассматривается как непременное условие, напрямую влияющее на производственный процесс и качество произведенной продукции: «больной производитель не может производить качественный товар» [6].

Профессиональная заболеваемость (ПЗ) является неотъемлемой частью общей заболеваемости населения. Она объединяет категории заболеваний, которые возникли в результате профессиональной деятельности человека и обусловлены исключительно или преимущественно влиянием вредных производственных фракторов [4, 6].

Цель работы - изучение динамики и структуры профессиональной заболеваемости в Республике Татарстан.

Материал и методы. Анализ выполнен на основе данных Управления Роспотребнадзора по Республике Татарстан (РТ), Республиканского регистра профессиональных заболеваний.

Результаты и их обсуждение. По данным Татарстанстата, на протяжении последних лет отмечается рост удельного веса работников, занятых во вредных и опасных условиях труда. На начало 2010 г. он составлял $23,4 \%$ от общей численности ра- ботающего населения, в 2011 г. - 26,6\%, в 2012 г. 28,3\%, в 2013 г. - уже 31,1\% [3].

Причинами неудовлетворительных условий труда являются изношенность основных производственных фондов и технологического оборудования, использование морально устаревших технологий, невысокие темпы модернизации предприятий, недостаточный уровень механизации и автоматизации технологических процессов, снижение ответственности работодателей за состояние условий и охраны труда.

Профрессиональная заболеваемость в РФ и РТ на протяжении последних 2004-2013 гг. сохраняется в пределах 1,52-1,99 случаев на 10000 работающих в Российской Федерации (РФ) и 1,16-1,87 — в Республике Татарстан (рис. 1). Показатель ПЗ в РТ в 2013 г. составил 1,87 случаев на 10000 работающих (РФ - 1,79) [1, 2, 3, 5].

В РТ удельный вес хронических профессиональных заболеваний в 2013 г. составил 99,2\%, острых профессиональных заболеваний - 0,8\%. В 2012 г. острые профрессиональные заболевания и отравления не регистрировались, в 2011 г. зарегистрировано хронических профзаболеваний - 97,5\%, острых - 2,5\%.

Анализ показателей ПЗ по разделам экономической деятельности выявил, что наиболее высокий уровень ее был зарегистрирован среди работников предприятий и организаций, включенных в раздел А «Сельское хозяйство» - 7,32 на 10000 работников (в 2012 г. - 6,05, в 2011 г. -6,83) [2, 3]. Второе 


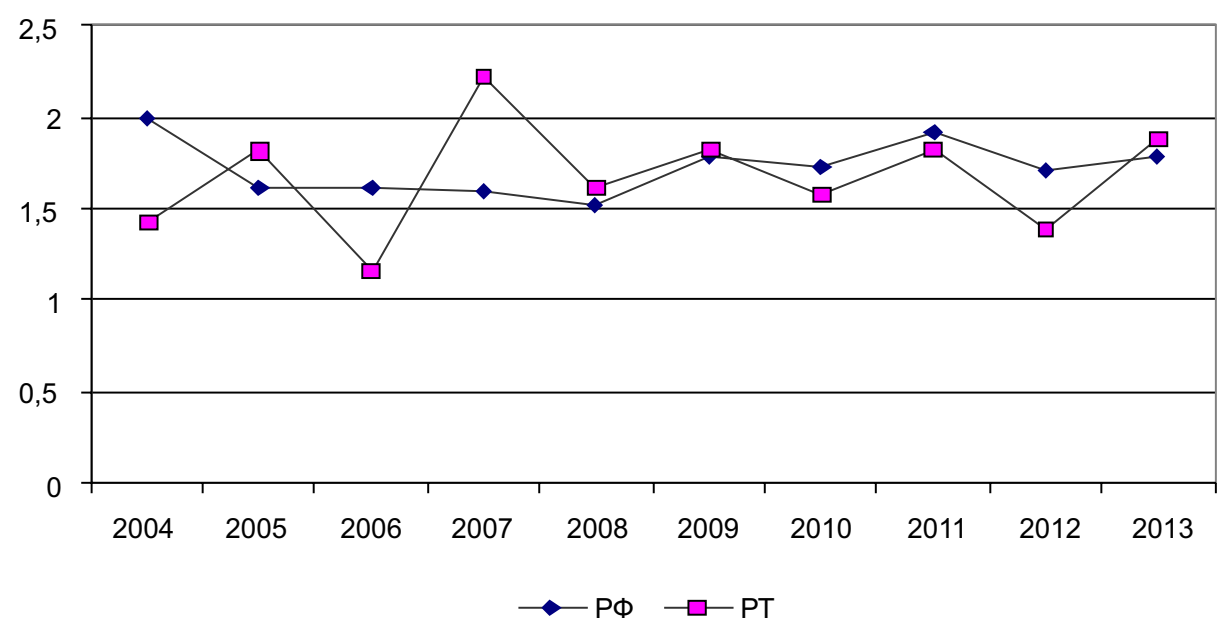

Рис. 1. Показатели профессиональной заболеваемости по Республике Татарстан и Российской Федерации в 2004-2013 гг.

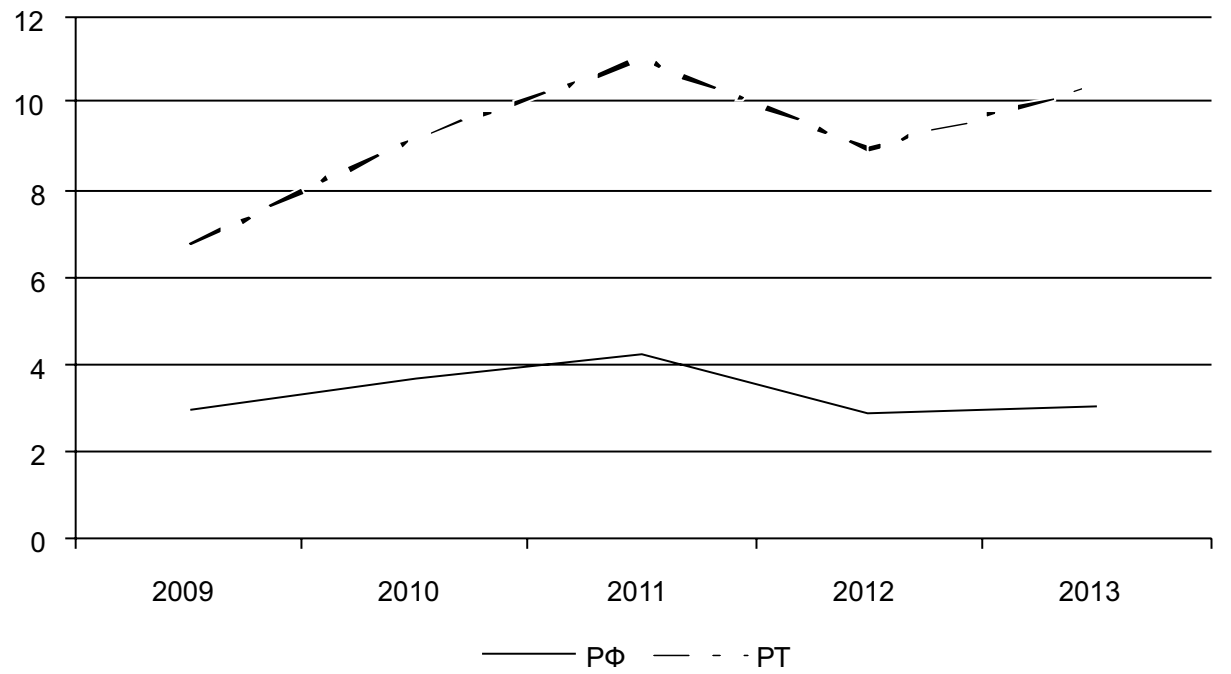

Рис. 2. Показатели профессиональной заболеваемости у работников сельского хозяйства РФ и РТ на 10000 работающих

ранговое место по уровню ПЗ занимает раздел D «Обрабатывающие производства» - 5,89 на 10000 работников (в 2012 г. - 3,46, в 2011 г. - 5,79). Третье ранговое место занимает раздел I «Транспорт и связь» - 1,74 на 10000 работников (в 2012 г. - 2,32, в 2011 г. - 1,28).

Сравнительный анализ ПЗ в РТ и РФ по разделу А «Сельское хозяйство» (рис. 2) свидетельствует о более высоких показателях в РТ на протяжении 2009-2013 гг. [3, 8].

В 2004-2013 гг. наиболее высокие показатели ПЗ отмечались на литейном заводе ОАО «КамАЗ», кузнечном заводе ОАО «КамАЗ», ОАО «КАПО им. С.П. Горбунова», ОАО «Казанский вертолетный завод», ОАО «Зеленодольский завод им. А.М. Горького, ОАО «Казанский вертолетный завод» и ОАО «Казанское моторостроительное производственное объединение» (табл. 1).

Анализ ПЗ показал, что по-прежнему лидируют заболевания, обусловленные воздействием физических фракторов (шум и вибрация), составившие в отчетном году $52,5 \%$. Второе место составили профессиональные болезни органов дыхания (ОД) от воздействия промышленных аэрозолей (20,9\%), третье - заболевания, связанные с воздействием физических перегрузок (18,6\%), четвертое - острые и хронические интоксикации (6\%), пятое - инфекционные болезни (1,2\%). Структура профессиональных заболеваний по этиологическому фактору аналогична российской.

Около трети зарегистрированных в 2013 г. диагнозов профессиональных заболеваний составляет двусторонняя нейросенсорная тугоухость $(\mathrm{HCT})$ - 33,5\%, на втором месте - заболевания органов дыхания (бронхиты, пневмокониозы, ринофарингиты) - 26,9\%, последующие ранговые места занимают вибрационная болезнь (ВБ) - 19\% и заболевания скелетно-мышечной системы (СМС) 18,2\% (табл. 2).

Практически у каждого четвертого больного в РТ (53 человека из 211) одновременно были диагностированы 2 и более профзаболеваний, при этом отмечается увеличение их удельного веса в 2 раза в 2013 г. $(24,5 \%)$ по сравнению с 2004 г. (11,9\%) (рис. 3). 
Таблица 1

Показатели профессиональной заболеваемости на отдельных предприятиях Республики Татарстан (на 10000 работающих)

\begin{tabular}{|c|c|c|c|c|c|c|c|c|c|c|}
\hline Предприятие & 2004 г. & 2005 г. & 2006 г. & 2007 г. & 2008 г. & 2009 г. & 2010 г. & 2011 г. & 2012 г. & 2013 г. \\
\hline КАПО & 3,7 & 11,6 & 24,6 & 29 & 17 & 12,2 & 15,8 & 29,8 & 10,5 & 28 \\
\hline КМПО & 3,7 & 14,8 & 5,6 & 4,1 & 11,9 & 17,6 & 9,9 & 28 & 13,2 & 13,2 \\
\hline KB3 & 17,5 & 11,1 & 9,7 & 1,5 & 10,7 & 7,3 & 5,65 & 8,5 & 9,9 & 22,6 \\
\hline Завод им. А.М. Горького & 12,1 & 14,6 & 14,4 & 6,6 & 1,4 & 6,5 & 6,8 & 31,5 & 45 & 19,1 \\
\hline Литейный завод & 61,4 & 80,3 & 34 & 79,1 & 64,2 & 83,25 & 64,7 & 86,3 & 33,5 & 91,6 \\
\hline Кузнечный завод & 39 & 29,3 & 9,4 & 19,1 & 27,3 & 29,2 & 4,9 & 48,8 & 12,4 & 51,9 \\
\hline PT & 1,42 & 1,81 & 1,16 & 2,22 & 1,61 & 1,83 & 1,58 & 1,82 & 1,39 & 1,87 \\
\hline
\end{tabular}

Таблица 2 Структура профессиональных заболеваний в Республике Татарстан (в \%)

\begin{tabular}{|l|c|c|c|c|c|c|c|c|c|c|}
\hline \multicolumn{1}{|c|}{ Заболевание } & 2004 г. & 2005 г. & 2006 г. & 2007 г. & 2008 г. & 2009 г. & 2010 г. & 2011 г. & 2012 г. & 2013 г. \\
\hline НСТ & 41,6 & 37,1 & 32,9 & 53 & 47,8 & 50 & 35,8 & 36,5 & 36,5 & 33,5 \\
\hline ВБ & 8,9 & 16,6 & 11,6 & 7,7 & 10,3 & 7 & 16,5 & 16,4 & 14,8 & 19 \\
\hline ПЗ ОД & 33,7 & 34,9 & 36,3 & 32,3 & 25,4 & 23,1 & 27,8 & 27,5 & 21,3 & 26,9 \\
\hline ПЗ СМС & 12,6 & 9,2 & 17,1 & 5,7 & 13,8 & 12 & 16 & 15,9 & 20,6 & 18,2 \\
\hline Прочие & 3,2 & 2,2 & 2,1 & 1,3 & 2,7 & 7,9 & 3,8 & 3,7 & 6,8 & 2,4 \\
\hline
\end{tabular}

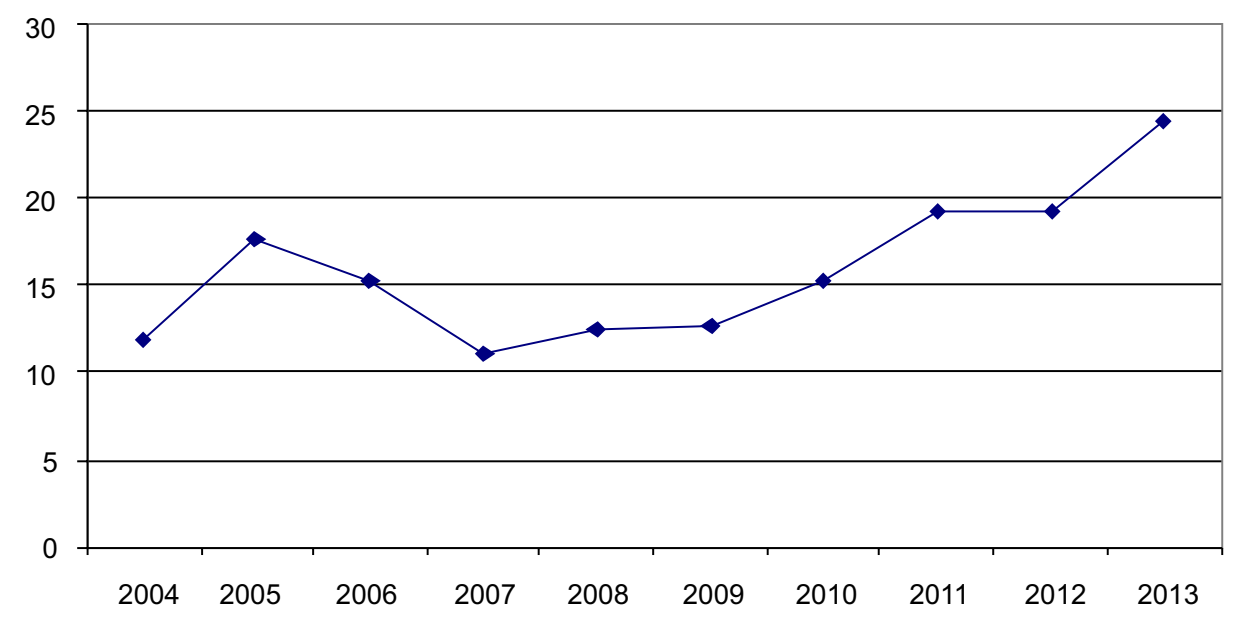

Рис. 3. Удельный вес больных с двумя и более установленными профессиональными заболеваниями (в \%)

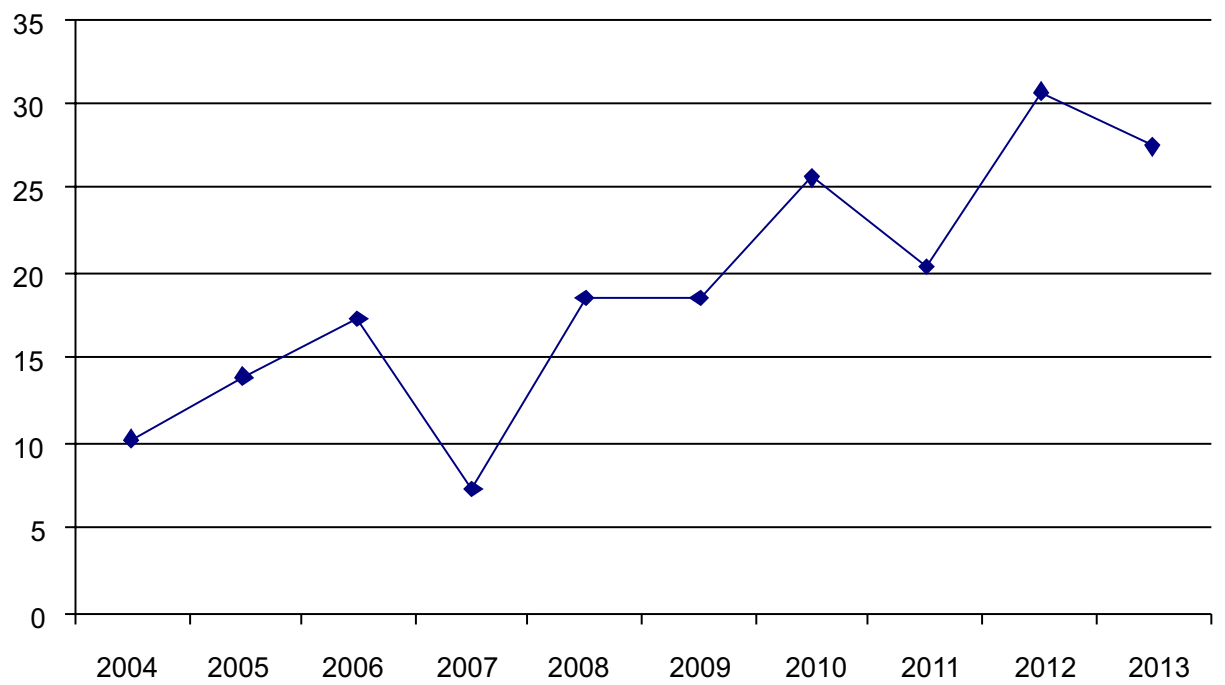

Рис. 4. Удельный вес профессиональных заболеваний, выявленных при обращении за медицинской помощью (в \%)

Также отмечается рост удельного веса больных дических медицинских осмотров (рис. 4). В 2004 г. профзаболеваниями, установленными при обраще- удельный вес таких больных был 10\%, тогда как в нии за медицинской помощью, а не в ходе перио- 2013 г. данный показатель составил 25,5\%. 
Нами проанализирована накопленная профессиональная заболеваемость. На 1 января 2014 г. регистр больных профессиональными заболеваниями содержал информацию на 6220 человек. Первое ранговое место занимает НСТ $(34,6 \%)$, второе ВБ $(24,4 \%)$, третье - болезни органов дыхания (23,3\%). Заболевания скелетно-мышечной системы составляют 13,1\%. Небольшой удельный вес имеют профессиональные заболевания, вызванные воздействием биологического фактора (2,2\%), и прочие болезни, составившие $2,5 \%$ (рис. 5).

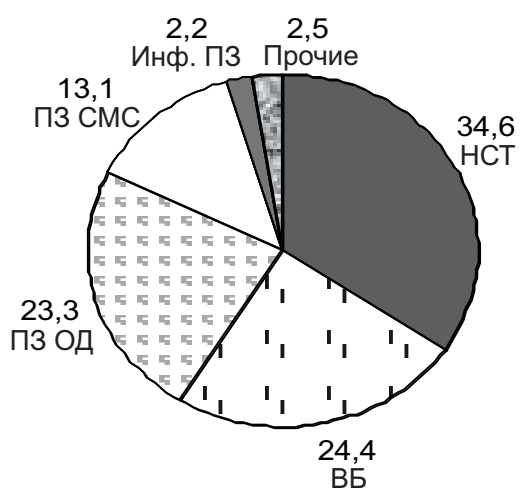

Рис.5. Структура накопленной профессиональной заболеваемости в Республике Татарстан (в \%)

Преобладающее большинство больных профзаболеваниями были лица мужского пола, составляющие от 65 до 75,8\%.

На протяжении изученного периода отмечается более высокий удельный вес профессиональных заболеваний среди работниц-женщин РТ по сравнению с данными РФ (рис. 6). Так, в РФ профрессиональные заболевания регистрировались у лиц женского пола в пределах 21,8-14,5\%, тогда как в РТ - 31,8-24,2\%.

У женщин чаще диагностировались заболевания скелетно-мышечной системы, составляющие $50-55 \%$, болезни органов дыхания (24-35\%).
Данное обстоятельство связано, прежде всего, с тем, что в центре профпатологии чаще обследуются работницы следующих профессий: животноводы, чей труд связан с физическими перегрузками, а также работницы литейного производства, контактирующие с промышленными аэрозолями и токсичными раздражающими веществами (стерженщицы, земледелы, гальваники и др.).

У мужчин наибольший удельный вес занимают профессиональные заболевания от воздействия физических факторов (ВБ, двусторонняя НСТ, хроническая бронхолегочная патология).

В 2013 г. профессиональные заболевания зарегистрированы в 70 профессиональных категориях работников. Профрессиями высокого профессионального риска стабильно остаются животноводы, сборщики-клепальщики, трактористы, электрогазосварщики и пилоты: в 11,85\% случаев профзаболевания установлены животноводам, в 8,7\% сборщикам-клепальщикам, в 8,7\% - трактористам, в 6,32\% - электрогазосварщикам ручной и контактной сварки и в 4,7\% - пилотам (табл. 3).

В 2013 г. среди лиц с установленным впервые диагнозом профессионального заболевания преобладали лица в возрасте 50-59 лет $(69,4 \%)$. По сравнению с 2012 г. возросло число больных с первичным установлением связи заболевания с профрессией в возрасте 60 лет и старше.

Сравнительный анализ распределения ПЗ по возрастным группам свидетельствует, что и мужчины и женщины обращаются в центр профрпатологии в предпенсионном и пенсионном возрасте. В возрасте 50-54 года диагноз П3 был установлен 31,8\% мужчин и 34,6\% женщин, в возрасте 55-59 лет - 38,5\% и $37,4 \%$ соответственно. Пенсионеров-мужчин было $17,5 \%$, пенсионеров-женщин - 39,2\%.

Распределение больных по профрессиональному стажу было следующим: до 9 лет - 3 чел. (1,43\%), 10 -14 лет - 16 чел. (7,6\%), 15-19 лет - 17 чел. (8,06\%), 20-29 лет - 74 чел. (35,1\%), 30-39 лет 95 чел. (45,03\%), 40 и более лет - 6 чел. (2,85\%).

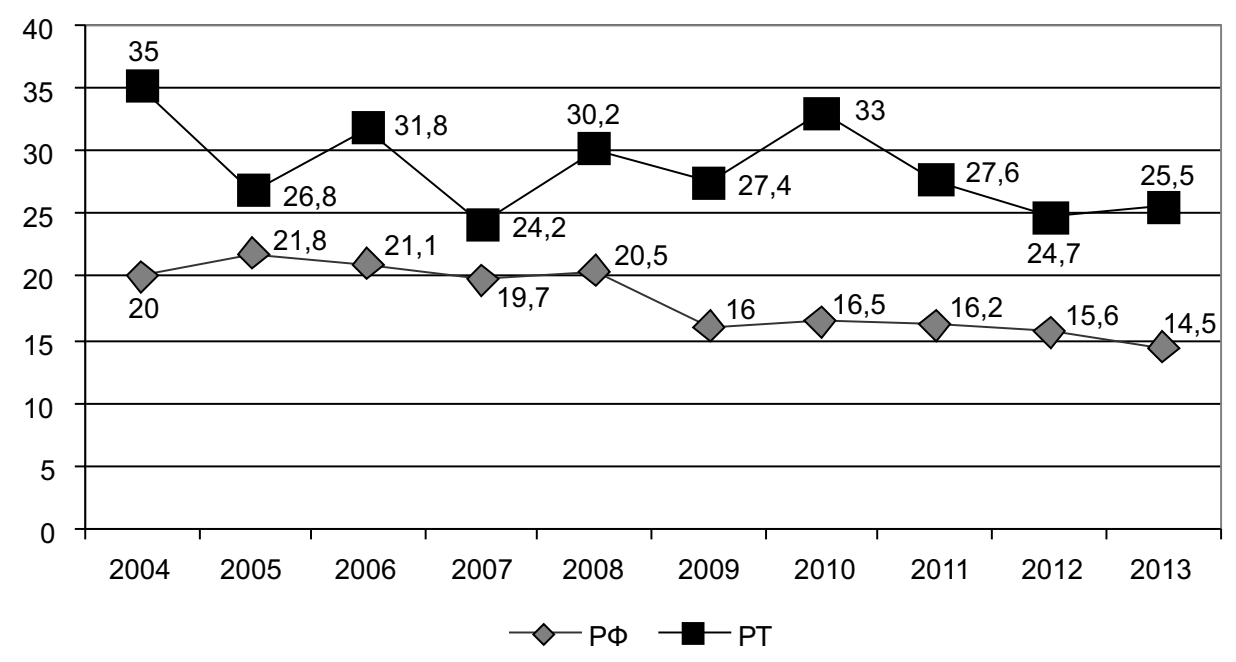

Рис. 6. Удельный вес профессиональных заболеваний женщин в Республике Татарстан и Российской Федерации в 2004-2013 гг. (в \%) 
Удельный вес профессиональных заболеваний по профессиям за 2011-2013 гг. (в \%)

\begin{tabular}{|l|c|c|c|}
\hline \multicolumn{1}{|c|}{ Профессия } & 2011 г. & 2012 г. & 2013 г. \\
\hline Животновод & 12,8 & 12,6 & 13,16 \\
\hline Сборщик-клепальщик & 3,0 & 6,0 & 8,69 \\
\hline Тракторист & 7,9 & 5,3 & 8,69 \\
\hline Электрогазосварщик & 7,9 & 4,6 & 7,9 \\
\hline Пилот & 4,92 & 12,6 & 4,74 \\
\hline Обрубщик & 7,4 & 3,3 & 3,16 \\
\hline Слесарь-инструментальщик & 4,4 & 3,3 & 3,55 \\
\hline Плавильщик & 0,5 & 0,7 & 2,76 \\
\hline Слесарь механосборочных работ & 3,4 & 3,3 & 1,58 \\
\hline Сборщик корпусов металлических судов & 2,0 & 3,3 & 1,58 \\
\hline
\end{tabular}

В 2013 г. наибольшее число больных было из г. Набережные Челны - 84 чел. $(39,8 \%)$, жителей г. Казани было 64 чел. (30,3\%). Жители других муниципальных образований составили 63 чел. $(29,9 \%)$

В 2009-2013 гг. профрзаболевания не устанавливались у работников 7 районов. В 2013 г. профессиональные заболевания диагностировались у жителей 24 районов. Как правило, подозрение на профзаболевание среди работников сельских районов устанавливается при обращении за медицинской помощью, поскольку руководители аграрных комплексов не организуют периодические медицинские осмотры (ПМО) своих работников.

Среди обстоятельств и условий возникновения хронических профессиональных заболеваний в 2013 г. в РТ по-прежнему первое место занимает несовершенство технологических процессов $(69,94 \%)$, на втором месте - конструктивные недостатки машин и технологического оборудования $(19,52 \%)$, на третьем - несовершенство рабочих мест (13,94\%) (puc. 7).
Профессиональные заболевания выявляются в основном у работников, имеющих контакт с вредным производственным фрактором не менее 10 лет. В 2013 г. на долю работников, имеющих стаж работы в контакте с вредным фактором 3039 лет, приходится 45,4\% всех зарегистрированных больных, 20-29 лет - 36,4\%, 10-19 лет $11,5 \%$. На долю работников, имеющих стаж более 40 лет и до 10 лет, приходится соответственно $3,9 \%$ и $2,8 \%$.

Основная доля профессиональных заболеваний $(72,5 \%)$ выявлена при прохождении работниками ПМО. Однако 27,5\% диагнозов хронических профессиональных заболеваний в 2013 г. были выявлены при активном обращении больных за медицинской помощью (в основном среди работников предприятий сельского хозяйства), в 2012 г. этот показатель составил 30,7\%, в 2011 г. - 20,4\%.

7,5\% впервые установленных профзаболеваний привели к утрате трудоспособности (в 2012 г. $20,6 \%$, в 2011 г. - 21,6\%), а в 0,8\% (2 случая) - к

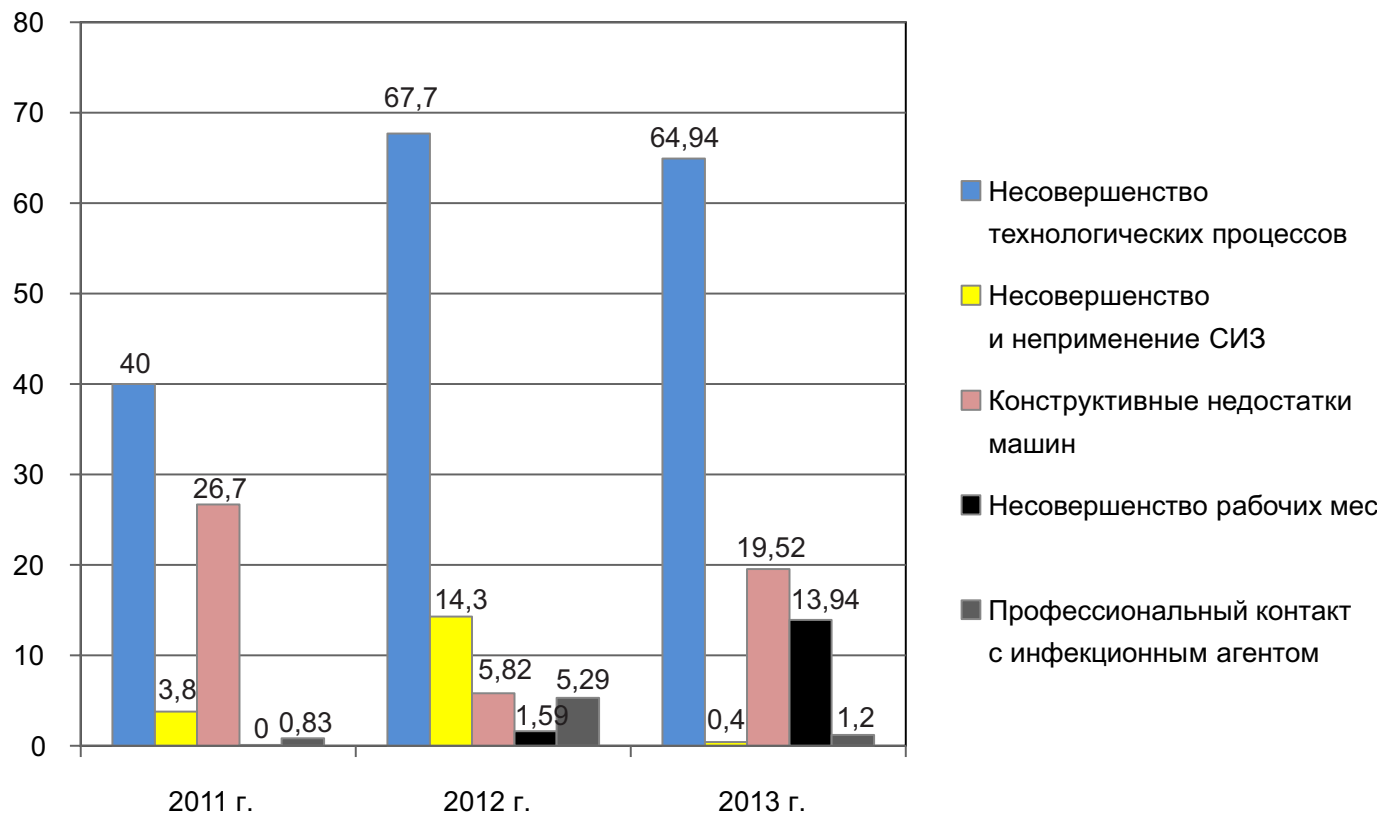

Рис. 7. Удельный вес обстоятельств и условий возникновения профессиональных заболеваний в Республике Татарстан в 2011-2013 гг. (в \%) 
первичной инвалидности (в 2012 г. - 1,06\%, в 2011 г. - 4\%).

Эти цифры свидетельствуют как о недостаточном качестве ПМО работников, занятых во вредных условиях труда, так и о несвоевременном их проведении.

Заключение. Уровень зарегистрированной хронической профессиональной заболеваемости не отражает реальную ситуацию, связанную с состоянием условий труда на производстве. В сложившейся экономической ситуации сокрытие потенциального профессионального заболевания возможно как со стороны работодателя во избежание повышенных выплат в Фонд социального страхования, так и со стороны медицинской организации с целью сохранения дальнейшего сотрудничества с предприятием по проведению ПМО. Немаловажное значение имеет желание самого работника сохранить рабочее место и вследствие этого - поздняя экспертиза связи заболевания с профессией. Так, подавляющее число больных $(80,13 \%)$ с первично установленным профессиональным заболеванием проработали в контакте с вредными и опасными производственными факторами 20-39 лет. Это приводит к диагностике профпатологии на поздних стадиях заболевания с потерей профессиональной трудоспособности.

Снижение показателей ПЗ в РТ обусловлено неудовлетворительным качеством проведения ПМО и недовыявлением больных с начальными признаками профзаболеваний.

Из числа зарегистрированных за последние 5 лет больных 20-30\% обратились за профпатологической экспертизой самостоятельно, а не в ходе ПМО. У работников сельскохозяйственных предприятий практически все случаи хронических профессиональных заболеваний были выявлены при обращении за медицинской помощью.

Большинство случаев профпатологии, выявленных при обращении работников за медицинской помощью, - это хронические формы профессиональных заболеваний, которые, как правило, установлены работникам со стажем работы с вредным производственным фрактором 20-39 лет (до 80\%) и возрастом свыше 50 лет (до 70\%).

Регулярно выявляются недостатки, влияющие на эффективность ПМО, из которых следует отметить отсутствие в составе врачебной комиссии профпатологов и врачей, прошедших повышение квалификации по вопросам организации и проведения предварительных и периодических медицинских осмотров.

Большинство врачей-специалистов, привлекаемых к медицинским осмотрам согласно приказу № 302н (онколог, психиатр, нарколог, дерматовенеролог, стоматолог и др.), являются представителями специализированных служб системы здравоохранения, и их работа в соответствующих медицинских организациях не предусматривает длительных отвлечений на проведение осмотров тысяч работников с соответствующей заменой специалиста на приеме или в стационаре. Других специалистов, например аллергологов, эндокринологов, слишком мало для полноценного обеспечения учреждений здравоохранения, исходя из чего, реальное привлечение достаточного количества врачей-специалистов к проведению массовых медицинских осмотров, которые требуют присутствия на осмотре в течение всего рабочего дня много дней подряд, крайне проблематично.

Практически не распознаются и не регистрируются такие профессиональные заболевания, как злокачественные новообразования, аллергозы органов дыхания, экзогенные токсические альвеолиты, прогрессирующая близорукость, опущение тазовых органов, в то время как риск их возникновения сохраняется на высоком уровне.

Серьезной проблемой является и противодействие работодателей по выполнению приказа Минздравсоцразвития от 12.04.2011 № 302н, регламентирующего направление в центры профпатологии стажированных работников 1 раз в 5 лет.

Комплексное решение задач по охране здоровья работающих с учетом межведомственной координации системы мер позволит обеспечить сохранение трудового потенциала, продлить трудовое долголетие, снизить общую и профессиональную заболеваемость.

\section{ЛИТЕРАТУРА}

1. Берхеева, З.М. Особенности профессиональной заболеваемости в Республике Татарстан / 3.М. Берхеева, И.М. Берхеев, И.Ю. Малышева [и др.] // Казанский медицинский журнал. - 2009. — № 4. C.518-521.

2. Государственный доклад «О состоянии санитарно-эпидемиологического благополучия в Российской Федерации в 2013 году». - М., 2014. С. $72-80$.

3. Государственный доклад «О состоянии санитарноэпидемиологического благополучия в Республике Татарстан в 2013 году». - Казань, 2014. - С.62-68.

4. Вопросы профессиональной заболеваемости: ретроспектива и современность / Н.Ф. Измеров, И.В. Бухтияров, Л.В. Прокопенко // Профессия и здоровье: материалы XI Всерос. конгр., Москва, 27-29 ноября 2012 г. - М.: ФГБУ «НИИ МТ» РАМН, 2012. - C.29-35.

5. Малышева, И.Ю. Состояние профессиональной заболеваемости, организация и качество периодических медицинских осмотров лиц, занятых на вредных работах и на работах с вредными и опасными производственными факторами, в Республике Татарстан в 2013 году / И.Ю. Малышева, 3.М. Берхеева, М.В. Трофимова // Информационный сборник. - Казань, 2013. - 28 c.

6. Материалы заседания Правительственной комиссии по вопросам охраны здоровья граждан / И.В. Бухтияров, Н.Ф. Измеров, Л.В. Прокопенко, Г.И. Тихонова, Н.А. Костенко // Медицина труда. — 2014. — № 7. C.1-19.

7. Приказ Министерства здравоохранения и социального развития Российской Федерации «Об утверждении перечней вредных и (или) опасных производственных факторов и работ, при выполнении которых проводятся предварительные и периодические медицинские осмотры (обследования), и Порядка проведения предварительных и периодических медицинских осмотров (обследований) работников, занятых на тяжелых 
работах и на работах с вредными и (или) опасными условиями труда».

8. Трофимова, М.В. Региональные особенности профессиональной заболеваемости в Республике Татарстан / М.В. Трофимова, 3.М. Берхеева // Научнометодическое обеспечение деятельности центров профрпатологии в современных условиях: материалы Bсерос. науч.-практ. конф. с международным участием, Шахты Ростовской области, 19-21 июня 2013 г. Шахты, 2013. - С.218-221.

\section{REFERENCES}

1. Berheeva, Z.M. Osobennosti professional'noi zabolevaemosti $\vee$ Respublike Tatarstan / Z.M. Berheeva, I.M. Berheev, I.Yu. Malysheva [i dr.] //Kazanskii medicinskii zhurnal. - 2009. — № 4. - S.518-521.

2. Gosudarstvennyi doklad "O sostoyanii sanitarnoepidemiologicheskogo blagopoluchiya v Rossiiskoi Federacii v 2013 godu». - M., 2014. - S.72-80.

3. Gosudarstvennyi doklad «O sostoyanii sanitarnoepidemiologicheskogo blagopoluchiya $v$ Respublike Tatarstan v 2013 godu». - Kazan, 2014. - S.62-68.

4. Voprosy professional'noi zabolevaemosti: retrospektiva i sovremennost' / N.F. Izmerov, I.V. Buhtiyarov, L.V. Prokopenko // Professiya i zdorov'e: materialy XI Vseros. kongr., Moskva, 27-29 noyabrya 2012 g. - M.: FGBU «NII MT» RAMN, 2012. - S.29-35.

5. Malysheva, I.Yu. Sostoyanie professional'noi zabolevaemosti, organizaciya i kachestvo periodi- cheskih medicinskih osmotrov lic, zanyatyh na vrednyh rabotah i na rabotah s vrednymi i opasnymi proizvodstvennymi faktorami, $v$ Respublike Tatarstan v 2013 godu / I.Yu. Malysheva, Z.M. Berheeva, M.V. Trofimova // Informacionnyi sbornik. - Kazan', 2013. - $28 \mathrm{~s}$.

6. Materialy zasedaniya Pravitel'stvennoi komissii po voprosam ohrany zdorov'ya grazhdan / I.V. Buhtiyarov, N.F. Izmerov, L.V. Prokopenko, G.I. Tihonova, N.A. Kostenko // Medicina truda. - 2014. - № 7. - S.1-19.

7. Prikaz Ministerstva zdravoohraneniya i social'nogo razvitiya Rossiiskoi Federacii «Ob utverzhdenii perechnei vrednyh i (ili) opasnyh proizvodstvennyh faktorov i rabot, pri vypolnenii kotoryh provodyatsya predvaritel'nye i periodicheskie medicinskie osmotry (obsledovaniya), i Poryadka provedeniya predvaritel'nyh i periodicheskih medicinskih osmotrov (obsledovanii) rabotnikov, zanyatyh na tyazhelyh rabotah i na rabotah s vrednymi i (ili) opasnymi usloviyami truda».

8. Trofimova, M.V. Regional'nye osobennosti professional'noi zabolevaemosti v Respublike Tatarstan / M.V. Trofimova, Z.M. Berheeva // Nauchno-metodicheskoe obespechenie deyatel'nosti centrov profpatologii $v$ sovremennyh usloviyah: materialy Vseros. nauch.-prakt. konf. s mezhdunarodnym uchastiem,. Shahty Rostovskoi oblasti, 19-21 iyunya 2013 g. - Shahty, 2013. S.218-221.

Принята 28.11.2014

() А.А. Варин, А.Л. Ханин, Ю.Б. Развозжаев, Н.В. Чистякова, 2015

УДК 616.25-082

\section{ОРГАНИЗАЦИЯ ВРАЧЕБНОЙ ПОМОЩИ ПРИ БОЛЕЗНЯХ ПЛЕВРЫ}

АЛЕКСАНДР АЛЕКСАНДРОВИЧ ВАРИН, КаНД. МеД. Наук, ДОцеНТ кафедры фтИЗИоПУЛЬМонологиИ ГБОУ ДПО НГИУВ Минздрава России, Новокузнецк, e-mail: omk_nktb@bk.ru

АРКАДИЙ ЛЕЙБОВИЧ ХАНИН, докТ. мед. наук, профессор, заслуженный врач РФ, зав. кафедрой фтизиопульмонологии ГБОУ ДПО НГИУВ Минздрава России, член экспертного совета ведущих пульмонологов СФО, Новокузнецк, e-mail: prof.khanin@yandex.ru

ЮРИЙ БОРИСОВИЧ РАЗВОЗЖАЕВ, канд. мед. наук, доцент кафедры лучевой диагностики ГБОУ ДПО НГИУВ Минздрава России, Новокузнецк, e-mail: postmastergiduv@rambler.ru

НАТАЛЬЯ ВАСИЛЬЕВНА ЧИСТЯКОВА, врач-ФтиЗИатр ГКУЗ КО НКПТД, Новокузнецк, Россия, e-mail: omk_nktb@bk.ru

Реферат. Цель работы - разработка методологии и обоснованных принципов организации лечебнодиагностического процесса при болезнях плевры. Материал и методы. Шестилетний ретроспективный анализ историй болезни 968 пациентов с болезнями плевры Специализированного центра при ГКУЗ КО НКПТД. Комплекс базовых методик включал игловую биопсию плевры; дополнительные исследования (по клинической ситуации); в исключительных случаях — пробную терапию туберкулеза; диспансерное наблюдение за выписанными пациентами. Результаты. В структуре болезней плевры основными являются туберкулез - 41,5\%, онкопатология - 23,3\%, пневмонии - 15,3\%, кардиогенные выпоты - 5,8\%. Группа редких поражений, включающая ургентные состояния (тромбоэмболия легочной артерии, острая абдоминальная патология, синдром Дресслера), составила 10,4\%, идиопатические плевриты - 3,7\%. Даны критерии диагностики основных болезней плевры. Проанализирована эффективность базовых методик и диагностическое значение косвенных симптомов. Это позволило построить ситуационный алгоритм действий, позволяющий не только решать конкретные задачи обследования, но и обеспечить взаимодействие специалистов - участников диагностического процесса. Другим организационным решением стало создание Регионального специализированного плеврального центра юга Кузбасса на базе ГКУЗ КО НКПТД. В течение года здесь обследуются до 160 пациентов, осуществляется консультативная помощь. Заключение. Организационные технологии (стандартизованный подход, алгоритм действий врача, создание специализированного плеврального центра) показали свою эфффективность. Сроки верификации диагноза для большинства больных $(91,0 \%)$ составили $(10,4 \pm 2,0)$ дня. Таким образом, разумный менеджмент является перспективным ресурсом, обеспечивающим решение конкретных клинических задач.

Ключевые слова: плеврит, болезни плевры, игловая биопсия плевры, специализированный центр, алгоритм. 


\title{
ORGANIZATION OF MEDICAL CARE IN PLEURAL DISEASES
}

ALEXANDER A. VARIN, Ph.D., associate professor of Department of phthisiopulmology of Novokuznetsk State Institute of Postgraduate Medicine of the Ministry of Health of Russia, Novokuznetsk, Russia, e-mail: omk_nktb@bk.ru ARKADIY L. KHANIN, D.M., Professor, Head of Department of phthisiopulmology of Novokuznetsk State Institute of Postgraduate Medicine of the Ministry of Health of Russia, Novokuznetsk, Russia, e-mail: prof.khanin@yandex.ru YURIY B. RAZVOZZHAEV, Ph.D., associate professor of Department of roentgenology of Novokuznetsk State Institute of Postgraduate Medicine of the Ministry of Health of Russia, Novokuznetsk, Russia, e-mail: postmastergiduv@rambler.ru NATALIA V. CHISTYKOVA, physician-phthsiologist of Clinical TB Dispensary, Novokuznetsk, Russia, e-mail: omk nktb@bk.ru

\begin{abstract}
Aim. To develop methods and reasonable principles of organization diagnostic and treatment for the pleural diseases (PD). Material and methods. Six-year retrospective analysis of case histories of 968 patients with PD, at a specialized center at Novokuznetsk Clinical Tuberculosis Dispensary. Set of basic techniques including needle biopsy of the pleura; additional biopsy (clinical-based decision); trial therapy for TB in exceptional cases; clinical supervision for discharged patients. Results. In the structure of pleural diseases the main ones are: TB - 41,5\% cancer - 23,3\%, pneumonia $-15,3 \%$, cardiogenic effusions $-5,8 \%$. Group of rare lesions, includes urgent conditions (pulmonary embolism, acute abdominal pathology, Dressler's syndrome) $-10,4 \%$, idiopathic pleuritis $-3,7 \%$. The main criteria for the diagnosis of pleural disease are presented. Effectiveness of basic techniques and diagnostic value of indirect symptoms is analyzed. It is possible to construct a situational action algorithm, which allows not only to solve specific problems survey, but also to interact experts - members of the diagnostic process. The creation of a specialized regional pleural center of the Southern Kuzbass based on Novokuznetsk Clinical TB Dispensary was another organizational solution. There are about 160 patients examines here for a year, advisory assistance provides. Conclusion. Organizational Technologies (standardized approach, the algorithm of doctor's actions, creation of a specialized pleural center) demonstrate its effectiveness. Time of verification of the diagnosis for the majority of patients $(91,0 \%)$ was $(10,4 \pm 2,0)$ days. Thus, a reasonable management is a promising resource, providing the solution of specific clinical tasks.
\end{abstract}

Key words: pleurisy, pleural disease, a needle biopsy of the pleura, the Specialized Center, algorithm.

B ведение. Каждое поколение врачей, сталкиваясь с проблемой оказания помощи пациентам с болезнями плевры (БП), оказывается в непростой ситуации. Во-первых, поражение плевральных листков, являясь манифестным появлением множества различных нозологических форм, не имеет специфических отличий. Поэтому в условиях узкой специализации врачей и отделений, а также ограниченных возможностей обследования трудности этиологической диагностики становятся неизбежными. Нередко проблемы диагностики и лечения терапевтических заболеваний, составляющих основную часть в структуре БП, решаются усилиями торакальных хирургов, причем на той стадии, когда возникают осложнения, связанные с неадекватной терапией на предшествующих этапах [2, 3, 7, 14]. Во-вторых, отсутствуют общепринятые стандарты и формализованный подход в ведении больных. Современные клинические рекомендации не всегда понятны и адаптированы к практической работе и нередко ориентированы на выполнение высокотехнологичных, но недоступных методик [8, 9]. В-третьих, организационные труд- ности. Например, стереотип оказания помощи в условиях многопрофильной больницы. Пациенты с плевральной патологией рассредоточены по стационару. Их доля в терапевтических отделениях составляет 5-10\%, пульмонологических — от 15 до $25 \%[11,12]$. В результате на врача при нагрузке 30 пациентов приходится от 2 до 7 реальных больных с плевритами. Врач несет ответственность за результат, значительный вклад в который вносится смежными специалистами (терапевт, пульмонолог, рентгенолог, хирург, цитолог, морфолог). Следовательно, должны быть решены проблемы взаимодействия, а тактика должна быть понятна всем участникам лечебнодиагностического процесса.

Цель работы заключается в разработке методологии и обоснованных принципов организации лечебно-диагностического процесса при БП.

Материал и методы. Шестилетний ретроспективный анализ историй болезни 968 пациентов Специализированного плеврального центра (СПЦ) при ГКУЗ КО НКПТД и комплекс базовых методик (табл. 1); дополнительные исследования, в том

Базовые исследования при болезнях плеврь

\begin{tabular}{|l|l|}
\hline $\begin{array}{l}\text { Клинико-анамнестические } \\
\text { данные }\end{array}$ & $\begin{array}{l}\text { Вариант дебюта (острый, постепенный) с выделением основного синдрома: торакалгия, } \\
\text { одышка, интоксикация. Наличие воспалительной интоксикации. Анамнез: туберкулез (ТБ), } \\
\text { контакт по ТБ; онкопатология, болезни крови, сердца; коллагенозы; ТЭЛА или фракторы ри- } \\
\text { ска; прием лекарственных средств; эндоскопические вмешательства (ФГдС, ФБС); травма; } \\
\text { алкоголизм, наркомания, ВИЧ-инфекция }\end{array}$ \\
\hline $\begin{array}{l}\text { Общеклинические } \\
\text { белок, фракции, сахар, амилаза, лдГ }\end{array}$ \\
\hline $\begin{array}{l}\text { жоракоцентез: плевральная } \\
\text { жикость }\end{array}$ & $\begin{array}{l}\text { Клинический анализ, окраска по Граму; наличие опухолевых клеток (ОК), микобактерий ту- } \\
\text { беркулеза (МБТ); бактериологическое исследование: посевы на микрофлору, МБТ; содержа- } \\
\text { ние белка, глюкозы, амилазы, рН, лдг }\end{array}$ \\
\hline $\begin{array}{l}\text { Рентгенологическое } \\
\text { исследование }\end{array}$ & $\begin{array}{l}\text { Обзорная и боковая рентгенограммы; томография легкого и средостения (после удаления } \\
\text { плевральной жидкости) }\end{array}$ \\
\hline Игловая биопсия плевры & З-4 кусочка париетальной плевры для гистологического исследования; мазки на ОК, МБТ \\
\hline
\end{tabular}


числе видеоторакоскопия, спиральная компьютерная томография (СКТ), фибробронхоскопия, ультразвуковое исследование (УЗИ); в исключительных случаях - пробная терапия туберкулеза; диспансерное наблюдение за выписанными пациентами. В СПЦ госпитализировались больные из лечебнопрофрилактических учреждений (ЛПУ) и туберкулезных диспансеров юга Кузбасса без специального предварительного отбора.

Результаты и их обсуждение. В условиях различных по специализации отделений ЛПУ и фтизиатрической службы 70-95\% всей плевральной патологии приходится на четыре группы болезней в различном долевом соотношении. К ним относятся пневмонии, туберкулез (ТБ), рак; состояния, приводящие к накапливанию в полостях транссудата. Оставшуюся часть составляют так называемые редкие, а также идиопатические плевриты [2, 3, 5, 10-12]. Совпадение статистических тенденций отмечено и в нашем исследовании (рисунок).

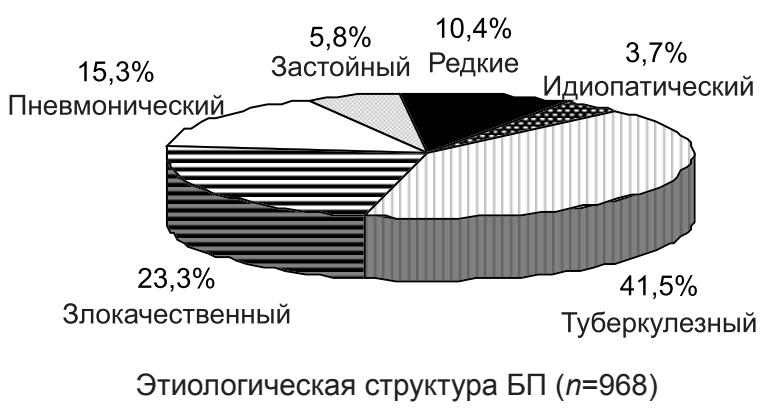

К числу редких БП (101 пациент) отнесены травматические плевриты - 33,7\%, плевриты при тромбоэмболии легочной артерии (ТЭЛА) - 18,8\%, абдоминальной патологии - 17,8\%, лекарственной аллергии - 13,9\%, единичные случаи волчаночных полисерозитов, плевритов при синдроме Дресслера, сепсисе, сифилисе, осложненных пороках развития легких. Каждая из основных групп БП имеет четкие критерии диагноза (табл. 2), базирующиеся на данных обследования.
В этиологической диагностике БП роль различных методик обследования неоднозначна. Полученные результаты могут быть патогномоничны определенной болезни или быть вероятностными, изменяя клиническую ситуацию. Совокупность клинико-анамнестических и лабораторных данных фрормирует первые представления об этиологии болезни. Торакоцентез с комплексным исследованием плевральной жидкости и последующее рентгенологическое исследование детализируют клиническую картину. Биопсийные вмешательства направлены на верификацию ТБ и злокачественные плевриты. Каждый этап обследования имеет особенности.

С точки зрения практического врача, первоочередными являются действия, направленные на диагностику состояний, угрожающих жизни пациента. К таковым относятся заболевания, в большинстве своем составляющие группу редких поражений плевры: ТЭЛА, инфаркт миокарда (гидроторакс вследствие падения сократительной способности сердца; плеврит при синдроме Дресслера); абдоминальная патология (панкреатогенные и реактивные плевриты); травматические, в том числе ятрогенные поражения плевры с возможным гемотораксом. В этих ситуациях приоритет базовых знаний врача и традиционных, клинических тестов является неоспоримым. Манифестные симптомы: анемия (внутреннее кровотечение, гемоторакс), высокий лейкоцитоз (острый живот; нагноение экссудата); ЭКГ-признаки инфаркта, ТЭЛА, аритмии; высокий уровень амилазы экссудата при панкреатите.

Плевральный выпот (ПВ) является показанием для проведения диагностического торакоцентеза. В настоящее время не существует неинвазивных способов определения эмпиемы плевры и гемоторакса, а нередко и этиологии плеврита. Однако дискуссия об условиях выполнения процедуры при массивном выпоте и необходимости ее выполнения при небольших объемах ПВ дезориентирует врачей. Неуверенность терапевта, боязнь осложнений, попытки делегировать выполнение пункции хирургам и, наконец, мысль о вторичности БП становятся серьезными аргументами для отказа от вмешательства. В этой связи можно отметить и легкость, с которой в большинстве случаев только по клинической картине

Таблица 2

Критерии диагноза для основных групп болезней плевры

\begin{tabular}{|c|c|}
\hline Генез плеврита & Критерии \\
\hline Пневмонический & $\begin{array}{l}\text { Наличие инфильтрата в легком, документированного данными рентгенографического исследо- } \\
\text { вания; его рассасывание после 10-12 дней адекватной антибактериальной терапии; парал- } \\
\text { лельное прекращение экссудации в плевральную полость }\end{array}$ \\
\hline Туберкулезный & $\begin{array}{l}\text { Обнаружение МБТ в патологическом материале (мокрота, экссудат), туберкулезных гранулем в } \\
\text { биоптатах плевры. При их отсутствии - методом исключения других патологических процессов } \\
\text { (в том числе, по результатам катамнеза), эфффектом противотуберкулезной терапии }\end{array}$ \\
\hline Злокачественный & $\begin{array}{l}\text { Морфологическое подтверждение получения ОК или опухолевой ткани (мокрота, экссудат), } \\
\text { верификация первичного рака }\end{array}$ \\
\hline $\begin{array}{l}\text { Кардиогенный (левоже- } \\
\text { лудочковый) }\end{array}$ & $\begin{array}{l}\text { Указание на заболевание сердечно-сосудистой системы; симптомы левожелудочковой недо- } \\
\text { статочности; ЭКГ-признаки ИБС (инфаркт миокарда, рубцовые изменения, нарушения ритма); } \\
\text { преимущественно двусторонний транссудативный, свободный плевральный выпот; эффект } \\
\text { кардиотропной, в том числе мочегонной терапии }\end{array}$ \\
\hline Идиопатический & $\begin{array}{l}\text { Основное заболевание после выполнения базового исследования остается неизвестным; } \\
\text { быстрая (10-14 дней) регрессия плеврального выпота, отсутствие рецидивов плеврального } \\
\text { выпота по данным катамнеза (3 мес) }\end{array}$ \\
\hline
\end{tabular}


диагностируются кардиогенные (левожелудочковые) выпоты, доля которых в статистике США составляет примерно 70\% [5]. И только толерантность больного к сердечной и мочегонной терапии побуждает врача искать альтернативные причины гидроторакса. При этом могут изменяться характеристики плевральной жидкости, приобретающей черты экссудата. Поэтому разграничение транссудата и экссудата остается актуальным, совершенствуются и модифицируются критерии Лайта $[5,15]$ с единственной целью - выделить из общего потока больных с невоспалительными поражениями плевры. Этот прием был успешно использован среди пациентов СПЦ. Низкое содержание плеврального белка (<30 г/л) один из критериев формирования группы кардиогенных выпотов и типичный симптом цирроза печени и нефротического синдрома. Уровень ниже 20 г/л исключал все иные гипотезы. Примерно в 30\% случаев этот показатель был в интервале от 20 до 30 г/л и с учетом дополнительных критериев отнесен к транссудатам. В то же время этот симптом не являлся абсолютно специфичным и отмечен в 16,0\% случаев злокачественных плевритов, в 2,3\% - туберкулезных и в $1,8 \%$ - пневмонических.

Клеточный состав экссудата в основных группах с БП был представлен всеми вариантами: лимфоцитарный - 62,6, 76,7, 40\%; нейтрофильный - 21, $16,6,31,8 \%$; эозинофильный 16,4, 6,7, 28,2\% для злокачественных болезней, ТБ и пневмонических плевритов соответственно. Отнесение серозного экссудата к геморрагическому (визуальные признаки, содержание эритроцитов < 5,0×10\%/л) позволяет прогнозировать ситуацию, при которой в структуре геморрагических плевритов доля злокачественных поражений составила 49\%, а $38 \%$ злокачественных ПВ имели примесь крови. Реальным же доказательством злокачественности плеврита является обнаружение ОК в экссудате. Из 208 больных данной группы ОК в экссудате обнаружены у 108 (51,9\%) пациентов, 86,1\% (93) положительных находок пришлось на серию из первых трех анализов, 2 последующих пункции поднимали результат до 95,3\% (103). Результативность метода была статистически одинаковой при серозных $[(51,2 \pm 4,4) \%, n=127]$ и геморрагических $[(48,8 \pm 5,5) \%, n=81]$ выпотах и не зависела от лейкоцитарного характера экссудата. Таким образом, чувствительность исследования составила 51,9\%, специфичность - 98\%. Наиболее частым вариантом рака была аденокарцинома 69,5\% (75). В 101 случае (93,5\%) из 108 цитологическое исследование экссудата оказалось решающим методом, позволившим доказать злокачественный генез плеврита. Информативность исследования плевральной жидкости при ТБ оказалась чрезвычайно мала: единичные случаи обнаружения МБТ при бактериоскопии экссудата и 15,2\% - культуральным методом. При этом время роста колоний МБТ на питательных средах составляло 2-3 мес.

Классическое рентгенологическое исследование при БП было направлено на выявление и детализацию патологических процессов легких и средостения. Плевральная тень не должна наслаиваться и закрывать легкое, а растекание жидкости снижать качество томограмм. Достигнуть этого можно максимальным удалением плеврального выпота. Рентгенологические находки обнаружены в 31,9\% (128) случаев ТБ-плевритов, 49,8\% (112) - злокачественных, 95,3\% (141) - пневмонических и отнесены к соответствующим классам [6]. Инфильтрат находили во всех случаях пневмоний, в 66,4\% (85) случаев туберкулеза и только в 8,9\% (10) - рака легкого. Очаговые изменения (9) были обусловлены туберкулезом, а все ателектазы (38) - раком легкого. Выявление округлой тени требовало разграничения между периферическим раком легкого (48) и туберкулемой (16). Причем вероятность обнаружения злокачественного плеврита (ЗП) была достоверно выше $(p<0,001)$. При диссеминированных процессах вероятность злокачественного (15) и туберкулезного поражений (15) оказалась равной. Кольцевидная тень при кавернозном ТБ обнаружена у 3 пациентов и только однажды при периферическом, распадающемся раке легкого. В 34 (26\%) случаях 3П патологический процесс с легкого распространялся на лимфатические узлы средостения. У 19 больных определялось изолированное поражение средостения опухолью. Отсутствие рентгенологических изменений в легких (изолированный плеврит) доказано у большинства больных ТБ-плевритом (68,1\%), у половины $(50,2 \%)$ злокачественным плевритом и во всех случаях кардиогенных выпотов. Следует отметить, что у 7 (4,7\%) больных пневмоническим плевритом инфильтрат можно было увидеть на снимках, выполненных пациентам в начале болезни, но на момент поступления в СПЦ изменения в легких отсутствовали. Трудности разделения легочной и плевральной патологии при массивных плевральных наложениях и осумковании ПВ удавалось разрешить, использовав СКТ.

Отсутствие результата на предшествующих этапах было показанием для выполнения биопсийных методик. В нашей клинике предпочтение отдается пункционной биопсии плевры (ПБ), выполняемой под «имидж-контролем» (УЗИ, СКТ). В отличие от видеоторакоскопии, это малозатратная терапевтическая методика не требовала ведения больного в условиях торакального отделения. Более того, она выполнялась при адгезивных плевритах (13,0\% случаев) и при выраженном осумковании (22,5\%) как в случаях изолированных плевритов, так и при наличии патологии в легком в целях быстрой морфологической верификации процесса. Время, необходимое для гистологического заключения, составляло $(4,8 \pm 0,2)$ дня (медиана 4,0$)$. Опыт 562 ПБ, из которых 323 (57,5\%) выполнены при ТБ-плевритах, 79 (14\%) при злокачественных, 160 $(28,5 \%)$ при прочих патологических процессах, позволяет утверждать, что и в современных условиях это исследование является высокоэффективным и малотравматичным. Гистологическое исследование было результативным у 261 (80,8\%) пациента с ТБплевритом и у $48(60,8 \%)$ с ЗП. Информативность ПБ при туберкулезе была максимальной при наличии свободной жидкости, снижаясь по мере осумкования и организации. Максимальные различия $(p<0,01)$ в возможностях метода обнаружены при свободном 
выпоте [(85,6 $\pm 2,7) \%, n=174]$ и адгезивном плеврите $[(68,9 \pm 5,9) \%, n=61]$. Обратные соотношения при 3П: результативность ПБ оказалась достоверно выше у больных с адгезивными процессами по сравнению с теми, у кого в плевральной полости выявлялась жидкость: $(85,7 \pm 9,7) \%(n=14)$ против $(55,4 \pm 6,2) \%$ ( $n=65)$. В конечном счете чувствительность методики при ТБ-плевритах составила 80,8\%, специфичность - 99,2\%, при 3П - 60,8\% и 100\% соответственно. У $65 \%$ пациентов с ТБ-плевритами и 20\% с ЗП игловая биопсия оказалась основным методом верификации диагноза. Осложнения ПБ в виде ограниченного пневмоторакса отмечены только у 3\% больных.

Прямым визуальным методом биопсийной диагностики БП, отнесенным нами к дополнительным, является видеоторакоскопия (ВТ). Исследование выполнялось только трем больным ЗП, что отражает его реальную необходимость. Так, в ведущих клиниках Казани и Саратова за год проводится от 9 до 12 ВТ для верификации поражений плевры [2, 3]. В нашем случае показанием для вмешательства было рецидивирующее течение плеврита при неэфффективности базовых методик обследования. В двух случаях выявлена злокачественная мезотелиома плевры, в третьем - патологии не обнаружено (случай паранеопластического плеврита у больного раком почки).

Дополнительные исследования имели целевую направленность. Наличие патологии в легком (ателектаз, сегментарное или долевое затемнение, диссеминация, круглая тень; «затяжные пневмонии») являлось показанием к проведению фрибробронхоскопии (ФБС), исследованию мокроты на ОК, МБТ. В $15,1 \%$ случаев злокачественных поражений плевры ФБС имела решающее значение. По ситуации выполнялись различные виды биопсий (периферических и внутригрудных лимфатических узлов, ребер, кожных образований), фиброгастродуаденоскопия, УЗИ органов брюшной полости и забрюшинного пространства, иммунологические тесты (антинуклеарные; противотуберкулезные антитела), допплеровское исследование периферических сосудов, эхокардиография, СКТ органов грудной клетки с контрастированием.

Этиологическую принадлежность БП не всегда удавалось установить в относительно короткие сроки - в рамках двух недель. Именно столько времени требуется на отработку одного из ключевых критериев парапневмонического плеврита, т.е. оценки результатов антибактериального лечения. К этому времени остается неизвестной судьба примерно 12\% больных с БП, косвенные симптомы которых могли принадлежать ТБ или злокачественным плевритам. Методом выбора становится назначение тест-терапии туберкулеза. Лечение должно быть контролируемым (ежедневный прием лекарственных форм под наблюдением медперсонала) и проводиться в условиях туберкулезного стационара. Критерии эфффективности - динамика клинических проявлений, накопления экссудата. Для оценки лечения требуется от одного до двух месяцев, что подтверждается закономерностями регрессии ПВ у 316 больных ТБ-плевритом: первые 2 нед - 62\% (196), в сроки до 1 мес - 92\% (291). Только в 8\% (25) случаев экссудация в плевральную полость сохранялась более 1 мес. При ЗП выпот рецидивировал у 88,5\% (184) больных, а разрешение выпота наблюдалось у $11,5 \%$ (24), что было обусловлено облитерацией плевральной полости растущей опухолью. Имеет значение и количество жидкости, удаляемой за одну пункцию, составлявшее $(0,75 \pm 0,04)$ л $(n=208)$ у больных $3 П$ и $(0,41 \pm 0,02)$ л $(n=316)$ при ТБ-плевритах. Ретроспективный анализ исследования показал, что пробная терапия назначалась 91 (22,7\% от группы) больному ТБ-плевритом и лишь $25(11,1 \%)$ пациентам с онкологической патологией. Чаще всего это было обусловлено отказом больных от инвазивных вмешательств.

И наконец, отдельного обсуждения заслуживают 7\% (55) больных, у которых при выписке из СПЦ генез плеврита остался неясным. Причины: благоприятное течение и ликвидация ПВ в первые 2 нед пребывания в СПЦ, в части случаев - незавершенность обследования в связи с отказом или уходом больных из стационара. Наблюдение пациентов в диагностической группе диспансерного учета позволило в 17 случаях выявить рецидивы ПВ. При повторной госпитализации у 12 больных диагностирован ТБ, у 5 - злокачественный плеврит. В итоге данные катамнеза позволили сократить долю идиопатических плевритов до 3,7\%.

Таким образом, каждый этап обследования несет информацию, достаточную для этиологической диагностики БП или для направления дальнейших действий. Последовательность диагностического процесса можно представить в виде основных положений:

1. Диагностика неотложных состояний (инфаркт миокарда, ТЭЛА, острая абдоминальная патология, гемоторакс, эмпиема, пневмоторакс).

2. Полипозиционное рентгенологическое исследование и/или УЗИ плевры. При обнаружении жидкости - плевральные пункции с максимальным удалением выпота: для исключения инфицирования экссудата, эмпиемы и гемоторакса; исследования на ОК, МБТ; разграничения транссудата и экссудата; в лечебных целях; для контроля эффрективности терапии.

3. Рентгенологическое обследование легких и средостения. При наличии патологии в легком определяется класс изменений и динамика легочного процесса.

4. При отсутствии достоверных симптомов - ПБ, при неудаче - видеоторакоскопия.

5. В случае отказа пациента от биопсии плевры или неспецифическом результате гистологического заключения методом выбора является тест-терапия ТБ.

6. Идиопатический плеврит - наблюдение в диагностической группе учета туберкулезного диспансера до получения результатов посевов на МБТ.

Следует отметить, что врачебная тактика - это не только перечень и последовательность возможных методик обследования, а применение их в соответствии с клинической ситуацией для достижения конкретных целей. Промежуточными целями могут 
быть доказательство отсутствия инфильтрата в легком (субстрата пневмонии); отбор пациентов для биопсийной диагностики, тест-терапии ТБ и др., конечной целью - установление нозологической принадлежности БП. Клиническая ситуация - это комплекс вероятностных факторов, включая возраст больных, пол, профессиональную вредность, данные анамнеза, обследования, эпидемиологические аспекты. Например, наличие изолированного плеврита у пациента в возрасте до 40 лет. Вероятность ТБ составляет 75,7\%. При тех же условиях геморрагический характер выпота у больных старше 40 лет позволяет прогнозировать 3П в 59,0\% случаев, а в возрасте от 60 и старше эта цифра увеличивается до $77,2 \%$. Статус может меняться в зависимости от эффректа тест-терапии, динамики накапливания экссудата. Ситуация определяет выбор оптимальных методик для поиска абсолютно специфичных симптомов с учетом имеющихся ресурсов клиники. Поэтому целесообразность действий врача и принятия решений в рамках ситуационного алгоритма [1] выглядит убедительной.

Алгоритм - это система правил, определяющих содержание и последовательность операций, обеспечивающих решение задач определенного класса [13]. Практическая сторона вопроса состоит в том, что решением частных задач при БП занимаются специалисты различных служб (рентгенологическая, лабораторная, патолого-анатомическая, поликлиническая) и клинических подразделений больницы (торакальной хирургии, легочного туберкулеза). Взаимодействие на всех уровнях может быть достигнуто на понятной и принятой основе всеми участникам диагностического процесса. Алгоритм является необходимым связующим звеном, определяющим роль и функции каждого участника. Тем самым вопрос о клинических аспектах БП переходит в организационную плоскость. Необходимо отметить, что качество медицинской помощи зависит в том числе от удовлетворенности пациента от взаимодействия с медицинской системой. Статус отделения, условия и сроки диагностики, уровень и результативность обследования, информированность о болезни, профессиональные качества врача - фракторы, определяющие взаимоотношения с пациентом, являющимся в юридическом смысле потребителем медицинских услуг, а с позиций отечественного здравоохранения - главной фригурой, ради которой выстраивается вся система оказания медицинской помощи [4]. Совпадение интересов всех сторон стало возможным с организацией Peгионального специализированного плеврального центра юга Кузбасса на базе ГУЗ НКТБ (приказ ГУЗ г. Новокузнецка от 13.12.1997 № 439). В течение года здесь обследуются до 160 пациентов, осуществляется консультативная помощь. Сроки верификации диагноза для большинства пациентов $(91,0 \%)$ составили $(10,4 \pm 2,0)$ дня, а доля идиопатических плевритов - 3,7\%.

Выводы:

1. Трудности этиологической диагностики БП в значительной степени связаны с узкой специализацией отечественной медицины, отсутствием пре- емственности между различными службами и стандартного подхода в диагностике и лечении БП.

2. Врачебную тактику при БП можно формализовать в виде алгоритма. Трудностей диагностики и запущенных случаев можно избежать, согласуя действия врача с положениями алгоритма, опираясь на базовые исследования, ориентируясь на критерии диагноза основных групп БП.

3. Лечебно-диагностический процесс при БП технологичен, требует корректного коллективного взаимодействия и управленческих решений. Рациональной формой организации врачебной помощи больным с БП является создание региональных специализированных плевральных центров. Это обосновано как с позиций повышения качества лечебнодиагностического процесса, так и экономических: сокращаются сроки диагностики, число врачебных ошибок, доля идиопатических плевритов.

\section{ЛИТЕРАТУРА}

1. Варин, А.А. Заболевания плевры / А.А. Варин, А.К. Стрелис, А.Л. Ханин. - Томск: Красное знамя, 2003. - $144 \mathrm{c}$.

2. Видеоторакоскопия в диагностике и лечении экссудативных плевритов неясной этиологии / В.Ю. Матвеев, Р.М. Хасанов, Р.Ф. Гайфуллин [и др.] // Сб. трудов XX Нац. конгр. по болезням органов дыхания. - М., 2010. - C.544

3. Диагностическая видеоторакоскопия в арсенале пульмонологической комиссии / А.С. Бенян, С.Ю. Пушкин, Ю.В. Богданова [и др.] // Сб. трудов XX Нац. конгр. по болезням органов дыхания. - М., 2010. - C.546.

4. Медведев, Д. О задачах и перспективах развития российского здравоохранения / Д. Медведев // Вопросы экономики и управления для руководителей здравоохранения. - 2008. - № 4. - С.3-4.

5. Лайт, Р.У. Болезни плевры: пер. с англ. / Р.У. Лайт. М.: Медицина, 1986. - 376 с.

6. Линденбратен, Л.Д. Рентгенологические синдромы и диагностика болезней легких: учебник / Л.Д. Линденбратен, Л.Б. Наумов. - М.: Медицина, 1972. $472 \mathrm{c}$.

7. Лишенко, В.В. Лечебная тактика при фибринотораксе / В.В. Лишенко, Д.А. Зайцев // Пульмонология. 2010. — № 4. - С.54-57.

8. Маскелл, Н.А. Рекомендации Британского торакального общества (BTS) по обследованию взрослых больных с односторонним плевральным выпотом. Совместно с группой по болезням плевры Британского торакального общества, подгруппой Комитета по стандартам медицинской помощи Британского торакального общества: пер. с англ. / Н.А. Маскелл, Р. Дж. А. Бутланд // Пульмонология. - 2006. — № 2. - С.13-26.

9. Плевриты. Рациональная фрармакотерапия заболеваний органов дыхания: руководство для врачей / под ред. А.Г. Чучалина. - М.: Литтерра, 2004. С.348-356.

10. Подгурская, Е.П. Современный взгляд на особенности плевральных выпотов различного генеза / Е.П. Подгурская // Клиническая медицина - 2008. - № 5. C.61-63.

11. Соколов, В.А. Плевриты / В.А. Соколов. - Екатеринбург: Баско, 1998. - 240 с.

12. Стогова, Н.А. Общие принципы выявления больных и верифрикации диагноза при туберкулезном плеврите / Н.А. Стогова, Н.С. Тюхтин // Проблемы туберкулеза 2007. - № 2. - C.14-17. 
13. Тавровский, В.М. Лечебно-диагностический процесс. Теория. Алгоритмы. Автоматизация / В.М. Тавровский. - Тюмень: СофтДизайн, 1997. - 228 с.

14. Ханин, А.Л. Врачебные ошибки в ведении больных с заболеваниями плевры / А.Л. Ханин, А.А. Варин // Клиническая медицина. - 1999. - № 3. - С.20-22.

15. Light, R.W. Diagnostic principles in pleural disease / R.W. Light // Eur. Respir. J. — 1997. — № 10. — P.476481.

\section{REFERENCES}

1. Varin, A.A. Zabolevaniya plevry [Pleural disease] / A.A. Varin, A.K. Strelis, A.L. Hanin. - Tomsk: Krasnoe znamya, 2003. - $144 \mathrm{~s}$.

2. Videotorakoskopiya $v$ diagnostike i lechenii ekssudativnyh plevritov neyasnoi etiologii [Videothoracoscopy in the diagnosis and treatment of exudative pleurisy of unknown etiology] / V.Yu. Matveev, R.M. Hasanov, R.F. Gaifullin [i dr.] // Sb. trudov XX Nac. kongr. po boleznyam organov dyhaniya. - M., 2010. - S.544.

3. Diagnosticheskaya videotorakoskopiya $v$ arsenale pul'monologicheskoi komissii [Videothoracoscopy diagnostic arsenal pulmonology Commission] / A.S. Benyan, S.Yu. Pushkin, Yu.V. Bogdanova [i dr.] // Sb. trudov XX Nac. kongr. po boleznyam organov dyhaniya. - M., 2010. - S.546.

4. Medvedev, D. O zadachah i perspektivah razvitiya rossiiskogo zdravoohraneniya [About the problems and prospects of the Russian health care] / D. Medvedev // Voprosy ekonomiki i upravleniya dlya rukovoditelei zdravoohraneniya. - 2008. - № 4. - S.3-4.

5. Lait, R.U. Bolezni plevry: per. $s$ angl. [Diseases of the pleura: per. from English] / R.U. Lait. - M.: Medicina, 1986. - $376 \mathrm{~s}$.

6. Lindenbraten, L.D. Rentgenologicheskie sindromy i diagnostika boleznei legkih: uchebnik [Radiographic diagnosis of diseases and syndromes of lung: a textbook] / L.D. Lindenbraten, L.B. Naumov. - M.: Medicina, 1972. $-472 \mathrm{~s}$.

7. Lishenko, V.V. Lechebnaya taktika pri fibrinotorakse [Therapeutic tactics in fibrinotorakse] / V.V. Lishenko, D.A. Zaicev // Pul'monologiya. - 2010. — № 4. S.54-57.
8. Maskell, N.A. Rekomendacii Britanskogo torakal'nogo obschestva (BTS) po obsledovaniyu vzroslyh bol'nyh s odnostoronnim plevral'nym vypotom. Sovmestno s gruppoi po boleznyam plevry Britanskogo torakal'nogo obschestva, podgruppoi Komiteta po standartam medicinskoi pomoschi Britanskogo torakal'nogo obschestva: per. s angl. [Recommendations of the British Thoracic Society (BTS) survey of adult patients with unilateral pleural effusion. Together with the Group on Diseases of the pleura of the British Thoracic Society, a subgroup of the Committee on Standards of medical care of the British Thoracic Society: Per. from English] / N.A. Maskell, R. Dzh. A. Butland // Pul'monologiya. 2006. - № 2. - S.13-26.

9. Plevrity. Racional'naya farmakoterapiya zabolevanii organov dyhaniya: rukovodstvo dlya vrachei [Pleurisy. Ratsionalnaya pharmacotherapy of respiratory diseases: a guide for physicians] / pod red. A.G. Chuchalina. - M.: Litterra, 2004. - S.348-356.

10. Podgurskaya, E.P. Sovremennyi vzglyad na osobennosti plevral'nyh vypotov razlichnogo geneza [Modern look at the features effusions of various origins] / E.P. Podgurskaya // Klinicheskaya medicina - 2008. - № 5. - S.61-63.

11. Sokolov, V.A. Plevrity [Pleurisy] / V.A. Sokolov. Ekaterinburg: Basko, 1998. - $240 \mathrm{~s}$.

12. Stogova, N.A. Obschie principy vyyavleniya bol'nyh i verifikacii diagnoza pri tuberkuleznom plevrite [General principles of case-finding and verification of the diagnosis in tuberculous pleurisy] / N.A. Stogova, N.S. Tyuhtin // Problemy tuberkuleza - 2007. - № 2. - S.14-17.

13. Tavrovskii, V.M. Lechebno-diagnosticheskii process. Teoriya. Algoritmy. Avtomatizaciya [Diagnostic and treatment process. Theory. Algorithms. Automation] / V.M. Tavrovskii. - Tyumen': SoftDizain, 1997. — $228 \mathrm{~s}$.

14. Hanin, A.L. Vrachebnye oshibki v vedenii bol'nyh s zabolevaniyami plevry [Medical errors in the management of patients with diseases of the pleura] / A.L. Hanin, A.A. Varin // Klinicheskaya medicina. — 1999. — № 3. S.20-22.

15. Light, R.W. Diagnostic principles in pleural disease / R.W. Light // Eur. Respir. J. - 1997. - № 10. R.476-481.

Принята 01.09.2014

\title{
ТУБЕРКУЛЕЗНЫЕ ЭМПИЕМЫ ПЛЕВРЫ КАК ПРЕДИКТОР ЛЕТАЛЬНОГО ИСХОДА У БОЛЬНЫХ ТУБЕРКУЛЕЗОМ ЛЕГКИХ
}

\author{
АЛЕКСАНДР АЛЕКСАНДРОВИЧ ВАРИН, канД. меД. наук, доцент кафедры фтизиопульмонологии \\ ГБОУ ДПО НГИУВ Минздрава России, Новокузнецк, e-mail: omk_nktb@bk.ru \\ АРКАДИЙ ЛЕЙБОВИЧ ХАНИН, докт. мед. наук, профессор, заслуженный врач РФ, зав. кафедрой \\ фтизиопульмонологии ГБОУ ДПО НГИУВ Минздрава России, Новокузнецк, e-mail: prof.khanin@yandex.ru \\ ВЕНИАМИН АЛЕКСАНДРОВИЧ ФЕНСТЕР, врач-Патологоанатом ГКУЗ КО НКПТД, НовокуЗнецК, РосСИя, \\ e-mail:drbigben@rambler.ru
}

\begin{abstract}
Реферат. Цель исследования - изучение эфффективности стандартного комплекса лечебных мероприятий при туберкулезных эмпиемах плевры (ТЭП) в условиях ведения больных во фттизиохирургическом отделении туберкулезного стационара. Методика ведения больных ТЭП соответствовала протоколам и стандарту оказания медицинской помощи, основным принципам хирургического лечения эмпием. Материал. Ретроспективное исследование данных историй болезни пациентов торакального отделения за 2011-2012 гг. Результаты и их обсуждение. В 97\% (31) случаев формирование эмпиемы было обусловлено деструкцией легкого с образованием бронхоплеврального свища, что качественно меняло течение болезни. Доля летальных исходов составила $62,5 \%$. Существенную роль в танатогенезе играет массивность ТБ-процесса и его прогрессирование, обусловленное множеством взаимосвязанных факторов. У $90 \%$ больных были фиброзно-кавернозный туберкулез и казеозная пневмония. Острое течение ТЭП обусловлено воздействием лекарственно-устойчивых
\end{abstract}


(ЛУ/МЛУ) штаммов микобактерий туберкулеза (73\% случаев) в сочетании с неспецифической полимикробной микрофлорой (50\%). В половине случаев смерть пациентов наступила в первые 15 дней пребывания больного в торакальном отделении. Таким образом, развитие ТЭП у больных распространенными деструктивными формами ТБ легких является предиктором летального исхода, а низкая эффективность лечебных мероприятий переводит их в разряд паллиативных.

Ключевые слова: туберкулезные эмпиемы плевры, лекарственно-устойчивые фрормы туберкулеза, летальность.

\title{
TUBERCULOUS EMPYEMA OF PLEURA AS A PREDICTOR OF DEATH IN PATIENTS WITH PULMONARY TUBERCULOSIS
}

\author{
ALEXANDER A. VARIN, PhD., associate professor of Department of phthisiopulmology of Novokuznetsk State Institute \\ of Postgraduate Medicine of the Ministry of Health of Russia, Novokuznetsk, Russia, e-mail: omk_nktb@bk.ru \\ ARKADIY L. KHANIN, D.M., Professor, Head of Department of phthisiopulmology of Novokuznetsk State Institute \\ of Postgraduate Medicine of the Ministry of Health of Russia, Novokuznetsk, Russia, e-mail: prof.khanin@yandex.ru \\ VENIAMIN A. FENSTER, pathologist of Novokuznetsk Clinical TB Dispensary, Novokuznetsk, Russia, \\ e-mail: drbigben@rambler.ru
}

\begin{abstract}
Aim. To study the effectiveness of standard complex of medical events at TB empyema of pleura (TEP) in surgical in-patients of TB hospital. Management of patients with TEP corresponded with the protocols and standards of medical care, and also with basic principles of surgical treatment of empyema. Material. The retrospective investigation of thoracic department patient's past medical history data in 2011-2012. Results and discussion. In 97\% (31) of cases empyema was organized due to the lungs destruction with formation of bronchopleural fistula which changed qualitatively the progress of disease. A total of lethal ends counted up to $62,5 \%$. The massiveness of TB process plays the significant role in thanatogenesis and its evolution caused by the variety of interconnected factors. The basic clinic forms of TB according to the autopsy were the fibro-cavernous TB and caseous pneumonia $(90 \%$ of cases). The acute progress of TEP was due the interaction of drug resistant (DR/MDR) strains of TB mycobacteria ( $73 \%$ of cases) in combination with non-specific polymicrobial microflora $(50 \%)$. For example, $50 \%$ of patients' death occurred in the first 15 days of staying in the thoracic department. Thus, the progress of TEP among patients with wide-spread destructive forms of lungs TB is the lethal predictor and low effectiveness of medical events translate them into the palliative category.
\end{abstract}

Key words: tuberculosis empyema of pleura, drug resistant forms of tuberculosis, lethality.

$\mathrm{B}$ ведение. Эмпиемы плевры нередко осложняют течение туберкулеза легких. Формирование эмпиемы у больных туберкулезом (ТБ) значительно утяжеляет течение болезни, часто являясь смертельным осложнением [2, 3]. Клиническая картина и тяжесть состояния больного обусловлены переходом массивного легочного ТБ-процесса на плевральные листки контактно или за счет деструкции ткани легкого с образованием бронхоплеврального свища. При этом реакция организма обусловлена всасыванием микробных эндотоксинов с поверхности слизистой плевры, а также ответной воспалительной реакцией с выработкой и потреблением в воспалении белков острой фразы. Исходы лечения пациентов зависят от многих причин: протяженности легочного процесса, эффективности антибактериальной терапии, возможности санации полости эмпиемы, способности к компенсации патофизиологических изменений организма больного. В настоящее время существуют сложившиеся подходы к лечению неспецифических эмпием [1, 6-9], но мало публикаций, отражающих опыт ведения и результаты лечения туберкулезных эмпием плевры (ТЭП) [2, 3]. Изданный в России стандарт оказания помощи при ТЭП [5] ограничивается перечнем процедур и лекарственных препаратов. Это, несомненно, необходимо для расчета стоимости затрат, экспертной оценки со стороны страховых компаний, но не отражает осо- бенностей ведения данной категории больных. Остается неизвестной и эффективность использования ресурсов данного стандарта.

Цель исследования - изучение эффрективности стандартного комплекса лечебных мероприятий при туберкулезных эмпиемах плевры в условиях ведения больных во фтизиохирургическом отделении крупного клинического туберкулезного стационара. Методика ведения больных ТЭП соответствовала протоколам и стандарту оказания медицинской помощи [5], а также основными принципами хирургического лечения хронических эмпием. К последним относятся дренирование плевральной полости с аспирацией газа и гнойного содержимого; санация полости антисептиками; системная антимикробная терапия.

Материал и методы. Ретроспективное исследование данных историй болезни пациентов торакального отделения ГКУЗ КО НКПТД за 2011-2012 гг.

Результаты и их обсуждение. Пролечено 32 больных ТЭП: 28 мужчин и 4 женщины. Возраст составил $(43,7 \pm 2,3)$ года (медиана 43,5$)$. Из них жителями Новокузнецка были 15 пациентов, городов юга Кузбасса - 12, лица без регистрации - 5. По социальному статусу 17 пациентов трудоспособного возраста - безработные, 11 имели инвалидность (из них 8 по туберкулезу), 4 - пенсионеры. Примерно в каждом третьем случае (11) госпитализация в торакальное отделение осуществлялась бригадами скорой помощи. В остальных - по 
направлению фртизиатра поликлиники противотуберкулезного диспансера (6), внутрибольничным переводом (5), переводом из стационаров общей лечебной сети (10). Не отмечено ни одного случая изолированной эмпиемы плевры без ТБ-поражения легких. ТЭП являлись осложнениями следующих клинических фрорм туберкулеза легких (ТЛ): фибброзно-кавернозный (ФК) - 43,8\% (14), казеозная пневмония (КП) - 31,2\% (10), инфильтративный и диссеминированный - по 12,5\% (4). При этом только $9(28,0 \%)$ пациентов наблюдались во второй группе диспансерного учета, остальные - в первой как впервые выявленные больные. Во всех случаях ФКТЛ имелось прогрессирование ТБ, протекающее по типу казеозной пневмонии. Следует отметить, что в пяти случаях ФКТЛ у впервые выявленных больных первоначальным был диагноз «казеозная пневмония», и форма ТБ была уточнена на вскрытии. Таким образом, в общей сложности доля ФКТЛ и КП составила 75,0\%.

Объем поражения легких оценивался по рентгенологическим данным: двусторонний тотальный у 10 (31,2\%) больных; двусторонний с поражением, как правило, верхних долей - $8(25,1 \%)$; односторонний тотальный - 4 (12,5\%), односторонний долевой - 10 (31,2\%). В 97\% (31) случаев фрормирование эмпиемы было обусловлено деструкцией легкого с образованием бронхоплеврального свища. В 19 наблюдениях ТЭП диагностирована справа, в 13 - слева. При этом только у 1 больного в дебюте ТЭП была выраженная торакалгия, в $8(25,0 \%)$ случаях прогрессировала одышка, в 23 (72,0\%) - превалировали симптомы воспалительной интоксикации. Время от появления симптомов ТЭП до оказания помощи составило $(20,4 \pm 3,2)$ дня (медиана 15).

Статус больных ТЭП при поступлении в торакальное отделение определялся сочетанием симптомов дыхательной недостаточности (тяжесть одышки по шкале MRC 3-4-й степени) и воспалительной интоксикации, что подтверждалось показателями периферической крови. Лейкоцитоз в среднем составлял $(14,2 \pm 1,6) \times 10^{9}$ /л (медиана 11,6). При этом только у 10 больных он был ниже 8,0×10\% СОЭ - $(46,4 \pm 3,0)$ мм/ч (медиана 50,5), гемоглобин $(96,0 \pm 4,1)$ г/л (медиана 97,0). У 18 пациентов уровень гемоглобина не превышал 100 г/л.

Микобактерии туберкулеза (МБТ) при бактериоскопии и в посевах мокроты определялись у 29 $(90,6 \%)$ больных. Лекарственная устойчивость (ЛУ) МБТ обнаружена в 19 (73,\%) случаях, в 4 - чувствительность сохранена, в 6 - исследование не выполнено (смерть больного к моменту тестирования). Спектр устойчивости МБТ был следующим: ко всем препаратам первого ряда - у 8 пациентов, первого и второго ряда - у 6, значительным (к рифампицину или изониазиду) - у 5.

Следует отметить, что в формировании гнойного экссудата при наличии свища значительную роль играет попадание в плевральную полость неспецифической патогенной микрофлоры [10]. В нашем наблюдении в 4 (11\%) случаях бактерий в экссудате не обнаружено, в 16 (50\%) - отмечен рост бактерий в диагностическом титре ( $10^{6}$ и выше). Микробная фолора была смешанной, с преобладанием в 7 случаях грамотрицательной микрофлоры (P. aeruginosa, E. coli). Следует отметить как недочет в работе врача невыполнение данного исследования у 12 (39\%) пациентов.

Ресурсы антибактериальной терапии. Лечение всех больных ТЭП проводилось противотуберкулезными препаратами 1-го ряда (1-й и 2«А» режимы) [4, 5] с последующей коррекцией по результатам традиционного теста на спектр ЛУ. С учетом времени роста культуры МБТ на обычных средах коррекция противотуберкулезной терапии у впервые выявленных больных оказывалась возможной только после 2 мес пребывания пациентов в стационаре. И только в двух случаях оказалось возможным назначение 4-го режима лечения, что, впрочем, не повлияло на выживаемость этих пациентов.

Клинические рекомендации по лечению нетуберкулезных эмпием плевры [1,9] предлагают эмпирическое назначение меропенема в сочетании с метронидазолом. Выбор препаратов может меняться после определения вида и чувствительности микроорганизма к антибиотикам. При наличии бронхоплеврального свища при ТБ-процессе и характера высеваемой из экссудата микрофрлоры такая тактика выглядит обоснованной и не противоречит протоколам лечения ТЭП [5, 9, 10]. Однако в нашем наблюдении у 23 (72 \%) пациентов такая терапия не проводилась, а в 9 (28\%) случаях назначались антибиотики при идентифицированном микробном агенте. Летальность в этих группах составила 65,2 и 55,6\% соответственно, без статистических различий по частоте смертельных исходов. Таким образом, данный компонент лечения не улучшал прогноз заболевания.

Срок госпитализации больных в среднем составил $(68,0 \pm 12,2)$ дня (медиана 41,0$)$. Однако при летальном исходе (20 пациентов) эти сроки оказывались значительно короче $(p<0,05)-(17,7 \pm 4,4)$ дня (медиана 11,0). Общая летальность составила 62,5\% (20). Причем в 10 (50\%) случаях смерть наступила в первые 15 дней пребывания больного в торакальном отделении.

Среди умерших преобладали впервые выявленные пациенты (13), 7 относились к диспансерной группе хронических больных ТБ, известных противотуберкулезной службе. По данным аутопсии у 9 пациентов подтвержден ФКТЛ, у 9 - КП, у 2 - диссеминированный ТБ легких. Следует отметить, что в 75\% (15) случаев легочный процесс был двусторонним, при наличии у 13 (65 ) больных ЛУ МБТ следующего спектра: у 7 - ко всем препаратам 1-го ряда, у 3 - к тубазиду или рифрампицину, у 3 к препаратам 1-го и 2-го ряда. В 4 случаях чувствительность МБТ к препаратам была сохранена, в 3 - исследование не проводили. 
Заключение. Действия врача по стандарту оказания помощи при ТЭП, осложняющих легочные фрормы туберкулеза по критерию смертности, имеют низкую эффективность. Доля летальных исходов $(62,5 \%)$ значительно выше, чем в представленных публикациях [2, 3]. Такие различия, возможно, обусловлены более «легким» контингентом анализируемых авторами больных, у которых ТЭП не является следствием деструктивного поражения легких. Существенную роль в танатогенезе играет массивность ТБ-процесса и его прогрессирование, обусловленное множеством взаимосвязанных фракторов. Во-первых, это микробная агрессия лекарственно-устойчивыми штаммами МБТ в сочетании с неспецифической полимикробной микрофрлорой, во-вторых, наличие бронхоплеврального свища и, в-третьих, общие и местные реакции истощенного болезнью организма. В значительной части случаев антибактериальная терапия туберкулеза уже исчерпала свои возможности на предшествующих этапах за счет формирования ЛУ/МЛУ форм или нуждалась в коррекции в процессе лечения. В то же время включение в схему антибиотиков широкого спектра, направленных на подавление неспецифической микрофлоры, не влияло на прогноз заболевания. Таким образом, развитие ТЭП у больных распространенными деструктивными формами ТБ легких является предиктором летального исхода, а низкая эффективность лечебных мероприятий переводит их в разряд паллиативных, что требует структурных и организационных преобразований во фтизиатрической службе в соответствие с Приказом МЗ РФ № 932н (2013).

\section{ЛИТЕРАТУРА}

1. Бартлетт, Дж.Дж. Инфекции дыхательных путей: пер. с англ. / Дж.Дж. Бартлетт. - М.: Бином, 2000. С.88-94.

2. Корниенко, С.В. Анализ основных причин летальности в противотуберкулезном диспансере / С.В. Корниенко, С.Н. Здобникова // Туберкулез и болезни легких. 2011. — № 4. - С.208.

3. Полянский, В.К. Диагностика и хирургическая тактика при туберкулезной эмпиеме плевры / В.К. Полянский, Г.Г. Савицкий, В.В. Ковалев // Туберкулез и болезни легких. - 2011. - № 5. - С.118.

4. Приказ МЗ РФ от 23.03.2003 № 109 «О совершенствовании противотуберкулезных мероприятий в Российской Федерации».

5. Приказ МЗ и СР от 11.08.2005. № 513 «Об утверждении стандарта медицинской помощи больным туберкулезной эмпиемой плевры».

6. Цеймах, Е.А. Эмпиемы плевры. Частота возникновения, пункционная терапия, закрытое дренирование плевральной полости: обзор: ч.1 / Е.А. Цеймах, А.В. ЛеВин, П.Е. Зимонин, А.М. Самуйленков // Туберкулез и болезни легких. - 2009. - № 8. - С.3-9.

7. Цеймах, Е.А. Эмпиемы плевры. Консервативная терапия, экстракопоральные методы детоксикации, эндоскопические методы: обзор: ч.2 / Е.А. Цеймах, А.В. Левин, П.Е. Зимонин, А.М. Самуй- ленков // Туберкулез и болезни легких. - 2009. № 9. - С.3-11.

8. Цеймах, Е.A. Эмпиемы плевры. Оперативные методы лечения: обзор: ч.3 / Е.А. Цеймах, А.В. Левин, П.Е. Зимонин, А.М. Самуйленков // Туберкулез и болезни легких. - 2010. - № 3. - С.5-11.

9. Яковлев, С.В. Антибактериальная терапия осложненной пневмонии / C.B. Яковлев // Consilium medicum. 2005. - T. 7, № 4. - C.36-42.

10. Bacteriological etiology and antimicrobial treatment of pleural empyema. / C.N. Meyer, S. Rosenlund, J. Nielsen [et al.] // Scand. J. Infect. Dis. — 2011. — Vol. 43, № 3. P.165-169.

\section{REFERENCES}

1. Bartlett, Dzh.Dzh. Infekcii dyhatel'nyh putei: per. s angl. [ Respiratory tract infections: Per. from English] / Dzh. Dzh. Bartlett. - M.: Binom, 2000. - S.88-94.

2. Kornienko, S.V. Analiz osnovnyh prichin letal'nosti $v$ protivotuberkuleznom dispansere [Analysis of the main causes of mortality in TB dispensary] / S.V. Kornienko, S.N. Zdobnikova // Tuberkulez i bolezni legkih. — 2011. № 4. - S.208.

3. Polyanskij, V.K. Diagnostika i hirurgicheskaya taktika pri tuberkuleznoi empieme plevry [Diagnosis and Surgical Management of tuberculous empyema] / V.K. Polyanskij, G.G. Savickij, V.V. Kovalev // Tuberkulez i bolezni legkih. 2011. - № 5. - S.118.

4. Prikaz MZ RF ot 23.03.2003 № 109 «O sovershenstvovanii protivotuberkuleznyh meropriyatii v Rossiiskoi Federacii» [Order of the Ministry of Health of the Russian Federation from 03.23.2003. № 109 «On improvement of TB control activities in the Russian Federation»].

5. Prikaz MZ i SR ot 11.08.2005. № 513 «Ob utverzhdenii standarta medicinskoi pomoschi bol'nym tuberkuleznoi empiemoi plevry» [Order of the Ministry of Health and from 11.08.2005 № 513 «On approval of the standard of care of patients with tuberculous pleural empyema»].

6. Ceimah, E.A. Empiemy plevry. CHastota vozniknoveniya, punkcionnaya terapiya, zakrytoe drenirovanie plevral'noi polosti: obzor: ch.1 [Empyema. The frequency of occurrence, needle therapy, closed thoracostomy: review] / E.A. Ceimah, A.V. Levin, P.E. Zimonin, A.M. Samuilenkov // Tuberkulez i bolezni legkih. — 2009. — № 8. - S.3-9.

7. Ceimah, E.A. Empiemy plevry. Konservativnaya terapiya, ekstrakoporal'nye metody detoksikacii, endoskopicheskie metody: obzor: ch.2 [Empyema. The frequency of occurrence, needle therapy, closed thoracostomy: review] / E.A. Ceimah, A.V. Levin, P.E. Zimonin, A.M. Samuilenkov // Tuberkulez i bolezni legkih. — 2009. — № 9. — S.311.

8. Ceimah, E.A. Empiemy plevry, Operativnye metody lecheniya: obzor: ch.3 [Empyema. The frequency of occurrence, needle therapy, closed thoracostomy: review] / E.A. Ceimah, A.V. Levin, P.E. Zimonin, A.M. Samuilenkov // Tuberkulez i bolezni legkih. - 2010. — № 3. - S.5-11.

9. Yakovlev, S.V. Antibakterial'naya terapiya oslozhnennoi pnevmonii [Antibiotic therapy of complicated pneumonia] / S.V. Yakovlev // Consilium medicum. - 2005. - T. 7, № 4. - S.36-42.

10. Bacteriological etiology and antimicrobial treatment of pleural empyema. / C.N. Meyer, S. Rosenlund, J. Nielsen [et al.] // Scand. J. Infect. Dis. — 2011. — Vol. 43, № 3. P.165-169.

Принята 01.09.2014 


\title{
СРАВНИТЕЛЬНАЯ ОЦЕНКА СЕРДЕЧНО-СОСУДИСТОГО РИСКА ПРИ АРТЕРИАЛЬНОЙ ГИПЕРТЕНЗИИ И КОМОРБИДНОЙ ПАТОЛОГИИ
}

\author{
ГУЗЕЛЬ АХМЕТОВНА МУХЕТДИНОВА, докТ. мед. наук, доцент кафедры факультетской терапии ГБОУ ВПО \\ «Башкирский государственный медицинский университет» Минздрава России, Уфа, Россия, \\ тел. 8-927-23-371-09, e-mail: gmukhetdinova@yandex.ru \\ ЗУЛЬФИя РАШИТОВНА ВАХИТОВА, врач-терапевт терапевтического отделения ГБУЗ ЯНАО «Губкинская городская \\ больница», соискатель кафедры факультетской терапии БГМУ, тел. 8-917-37-078-28, e-mail: zulya-vakhitova@yandex.ru \\ РАИСА МУГАТАСИМОВНА ФАЗЛЫЕВА, докт. мед. наук, профессор кафедры факультетской терапии ГБОУ ВПО \\ «Башкирский государственный медицинский университет» Минздрава России, Уфа, Россия, \\ тел. 8-989-95-325-79, e-mail: facult.terapy-bgmu@mail.ru \\ ЛЮДМИЛА АЛЕКСАНДРОВНА ИБРАГИМОВА, дОкТ. мед. наук, профессор кафедры факультетской терапии \\ БОУ ВПО «Башкирский государственный медицинский университет» Минздрава России, Уфа, Россия, \\ тел. 8-347-27-392-82, e-mail: facult.terapy-bgmu@mail.ru
}

\begin{abstract}
Реферат. Цель исследования - сравнительное изучение факторов риска сердечно-сосудистых заболеваний у больных артериальной гипертензией (АГ) и субклиническим гипотиреозом (СГ). Материал и методы. Обследовано 86 пациентов в возрасте от 35 до 50 лет. В зависимости от функционального состояния щитовидной железы пациенты были разделены на 2 группы: первая группа - больные АГ 2-й стадии, вторая группа - больные субклиническим гипотиреозом, у которых ранее была диагностирована АГ 2-й стадии. Контрольная группа 25 практически здоровых лиц. Всем пациентам проводилось комплексное обследование, выявление факторов риска и определение высокочувствительного С-реактивного белка (вч-СРБ) в сыворотке крови. Результаты и их обсуждение. Выявлены корреляционные связи уровней гормонов щитовидной железы с факторами риска сердечно-сосудистых заболеваний. Представлены данные о прогнозировании 10-летнего риска развития сердечно-сосудистых осложнений у пациентов с артериальной гипертензией и субклиническим гипотиреозом по шкале Reynolds. Заключение. Субклинический гипотиреоз сопровождается изменениями липидного спектра и, как следствие, предрасполагает к более раннему развитию сердечно-сосудистых осложнений у больных АГ. Ключевые слова: факторы риска, артериальная гипертензия, субклинический гипотиреоз, высокочувствительный СРБ, шкала Reynolds
\end{abstract}

\section{COMPARATIVE ASSESSMENT OF CARDIOVASCULAR RISK FOR ARTERIAL HYPERTENSION AND COMORBID PATHOLOGY}

GUZEL A. MUKHETDINOVA, M.D., associate professor of Department of faculty therapy of SBEI HPE «Bashkir State Medical University», Ufa, Russia, tel. 8-927-23-371-09, e-mail: gmukhetdinova@yandex.ru ZULFIYA R. VAKHITOVA, candidate of a degree of Department of faculty therapy of SBEI HPE «Bashkir State Medical University», Ufa, Russia, tel. 8-917-37-078-28, e-mail: zulya-vakhitova@yandex.ru RAISA M. FAZLIYEVA, M.D., Professor of Department of faculty therapy of SBEI HPE «Bashkir State Medical University», Ufa, Russia, tel. 8-989-95-325-79, e-mail: facult.terapy_bgmu@mail.ru LUDMILA A. IBRAGIMOVA, M.D., Professor of Department of faculty therapy of SBEI HPE «Bashkir State Medical University», Ufa, Russia, tel. 8-347-27-392-82, e-mail: facult.terapy_bgmu@mail.ru

Abstract. Aim. The purpose of our study is a comparative study of risk factors for cardiovascular diseases in patients with arterial hypertension (AH) and subclinical hypothyroidism (SG). Material and methods. Under our observation were 86 patients in the age from 35 to 50 years. Depending on the functional state of thyroid, patients were divided into 2 groups: the first group - patients with hypertension stage 2, the second group - patients with subclinical hypothyroidism, with previously diagnosed hypertension stage 2 . A control group consisted of 25 almost healthy persons All patients underwent a comprehensive survey, identification of risk factors and the definition of high-sensitivity C-reactive protein (RF CRP) in the blood serum. Results. We revealed correlation of the levels of thyroid hormones with risk factors for cardiovascular disease. We demonstrated data on the prediction of a 10-year risk of cardiovascular complications in patients with arterial hypertension and subclinical hypothyroidism based on Reynolds scale. Conclusion. Subclinical hypothyroidism is accompanied by changes in lipid spectrum, and, as a consequence, predisposes to the earlier development of cardiovascular complications in patients with hypertension.

Key words: risk factors, arterial hypertension, hypothyroids, high-sensitivity CRP, scale Reynolds.

C реди ведущих факторов риска, вносящих значительный вклад в преждевременную смертность населения России, первые 3 места занимают такие факторы риска развития болезней системы кровообращения, как артериальная гипертензия $(35,5 \%)$, гиперхолестеринемия $(23 \%)$ и курение $(17,1 \%)$ [1]. В последние годы актуальным стал вопрос о взаимосвязи сердечно-сосудистых заболеваний (ССЗ), включая АГ, с тиреоидной па- тологией [2]. Субклинический гипотиреоз способен провоцировать дислипидемию и атерогенез, артериальную гипертензию, нарушение диастолической функции сердца [3]. По данным Н.М. Бакировой (2013), исследовавшей больных пожилого возраста с АГ и субклиническим гипотиреозом, установлено, что атерогенные изменения липидного спектра крови нарастают по мере повышения уровня тиреотропного гормона (ТТГ) [4]. 
В эпидемиологических исследованиях проводилось изучение С-реактивного белка как предиктора развития артериальной гипертензии и маркера сердечно-сосудистого риска [5], однако при коморбидной патологии, в частности при сочетании артериальной гипертензии с субклиническим гипотиреозом, данный показатель практически не изучен.

Цель исследования - оценить суммарный сердечно-сосудистый риск и значение высокочувствительного (вч) С-реактивного белка у больных артериальной гипертензией в сочетании с субклиническим гипотиреозом.

Материал и методы. Проведено комплексное обследование 86 пациентов с АГ в возрасте от 35 до 50 лет, находившихся на лечении в терапевтическом отделении Государственного бюджетного учреждения здравоохранения Ямало-Ненецкого автономного округа «Губкинская городская больница». В зависимости от функционального состояния щитовидной железы у пациентов были сорормированы 2 группы: 1-ю группу (44 пациента) составили больные АГ 2-й стадии с нормальной функцией щитовидной железы; 2-ю группу (42 пациента) - больные АГ 2-й стадии, у которых при обследовании был диагностирован субклинический гипотиреоз. Контрольная группа состояла из 25 практически здоровых лиц. По возрастным и гендерным характеристикам группы были сопоставимы. Всем больным проведены фризикальные методы обследования - рост, вес, окружность талии, индекс массы тела (ИМТ), артериальное давление (АД), частота сердечных сокращений (ЧСС); лабораторные - общий анализ крови (ОАК), общий анализ мочи (ОАМ), биохимический анализ крови и липидограмма [общий холестерин (ОХC), липопротеиды низкой плотности (ЛПНП), липопротеиды высокой плотности (ЛПВП), триглицериды (ТГ), креатинин]; инструментальные - ЭКГ, ЭхоКГ, УЗИ сосудов шеи; методом ИФА проведено исследование содержания вч-СРБ, тиреотропного гормона, тироксина ( $\mathrm{T}_{4}$-свободный) в крови.

Статистическая обработка полученных данных проведена с помощью пакета прикладных программ статистического анализа «Statistika 7.0». В случае параметрического распределения признака данные представлены в виде $\mathrm{M \pm m}$ (M - среднее арифметическое, m - ошибка средней арифметической), в случае непараметрического распределения - в виде Ме (25; 75) (Ме - медиана, 25 и 75 -1-я и 3-я квартили). Достоверность различий параметрических значений оценивалась с помощью критерия Стьюдента или непараметрического теста МаннаУитни. При сравнении качественных признаков в независимых группах использовали $\mathrm{X}^{2}$-критерий Пирсона. Корреляционный анализ проводили с использованием критерия Спирмена. Различия считали достоверными при $p<0,05$.

Результаты и их обсуждение. Характеристика «классических» фракторов риска у лиц с АГ и субклиническим гипотиреозом (СГ) и без него у обследованных нами пациентов представлена в табл. 1.

Приведенные данные свидетельствуют о более высокой частоте абдоминального ожирения при коморбидной патологии (71,4\% против 43,2\%), однако анализ с использованием критерия $x^{2}$ не позволяет с высокой долей вероятности утверждать о статистической достоверности данного результата. Окружность талии в группе больных АГ в среднем составила у женщин $(88,47 \pm 3,255)$ см, у мужчин - $(101,2 \pm 6,610)$ см; при коморбидной патологии - $(89,59 \pm 3,333)$ см у женщин $(p=0,910)$ и $(104,0 \pm 7,091)$ см у мужчин $(p=0,492)$. Вместе с тем в группе пациентов с АГ в сочетании с СГ отмечены более высокие показатели ИМТ и дислипидемии по сравнению с больными АГ. Показательно, что в целом в обеих группах средние значения ОХС, ЛПНП и ТГ превышали нормальные значения. При этом у больных АГ в сочетании с СГ выявлены достоверно более высокие значения показателей липидного профриля. Отмечена прямая зависимость средней силы между ИМТ и ОХС $(r=0,59 ; p<0,05)$, ЛПНП ( $r=0,58$; $p<0,05)$, ТГ $(r=0,54 ; p<0,05)$.

В группе пациентов с АГ и СГ установлено достоверное увеличение систолического артериального давления (САД) и диастолического артериального давления (ДАД). Корреляционный анализ выявил также прямую зависимость между уровнем САД и

Та блица 1

Показатели факторов риска у больных артериальной гипертензией

\begin{tabular}{|l|c|c|c|}
\hline \multirow{2}{*}{ Показатель } & \multicolumn{2}{c|}{ Группа пациентов } & \multirow{2}{*}{$\mathrm{X}^{2}, p$} \\
\cline { 2 - 3 } & 1-я группа & 2-я группа & \multirow{2}{*}{$\mathrm{X}^{2}=0,00 p=0,972$} \\
\hline Курение, абс. (\%) & $17(38,6)$ & $16(38,1)$ & $\mathrm{X}^{2}=1,92 p=0,165$ \\
\hline Абдоминальное ожирение, абс. (\%) & $19(43,2)$ & $30(71,4)$ & $\mathrm{X}^{2}=0,53 p=0,465$ \\
\hline Отягощенная наследственность, абс. (\%) & $20(45,4)$ & $25(59,5)$ & $p=0,022$ \\
\hline ИМТ, ке/м² & $30,68 \pm 5,102$ & $33,21 \pm 4,941^{*}$ & $p=0,016$ \\
\hline Общий холестерин, ммоль/л & $5,679 \pm 0,825$ & $6,178 \pm 1,053^{*}$ & $p=0,002$ \\
\hline ЛПНП, ммоль/л & $3,511 \pm 0,355$ & $3,888 \pm 0,709^{*}$ & $p=0,002$ \\
\hline ЛПВП, ммоль/л & $0,927 \pm 0,167$ & $0,817 \pm 0,159^{*}$ & $p=0,008$ \\
\hline Триглицериды, ммоль/л & $2,317 \pm 0,290$ & $2,522 \pm 0,407^{*}$ & $p=0,268$ \\
\hline Глюкоза, ммоль/л & $5,138 \pm 0,562$ & $5,292 \pm 0,718$ & \\
\hline
\end{tabular}

Примечание: *различия статистически значимы, $p$ - показатель достоверности различий между группами. 
следующими показателями: ОXC ( $r=0,60 ; p<0,05)$, ТГ $(r=0,49 ; p<0,05)$, ЛПНП $(r=0,55 ; p<0,05)$, ИМТ $(r=0,52 ; p<0,05)$, между уровнем ДАД и показателями OXC (r=0,53; $p<0,05)$, ТГ $(r=0,59 ; p<0,05)$, ЛПНП (r=0,49; $p<0,05)$, ИМТ (r=0,52; $p<0,05)$. Сила связи между уровнем САД и содержанием глюкозы в крови недостаточная, а в случае с уровнем ДАД статистически незначимая, что, вероятно, свидетельствует об отсутствии взаимного влияния данных показателей. В то же время обнаружена прямая зависимость между уровнем глюкозы и показателями липидного профиля - OXC $(r=0,35)$ и ЛПНП $(r=0,38 ; p<0,05)$.

Исследование уровня тиреоидных гормонов выявило следующие различия: уровень ТТГ в среднем у больных в группе АГ составил 2,115 $(0,550-3,580)$ мМЕ/л, у больных коморбидной патологией — 5,460 (4,150-7,010) мME/л; $p<0,001$. Уровень $\mathrm{T}_{4}$-свободный в 1-й группе составил 14,89 пмоль/л, во 2-й группе - 13,71 пмоль/л $(p=0,134)$. Выявлены статистически значимые корреляционные связи между уровнем ТТГ и уровнями OXC $(r=0,36 ; p<0,05)$, ЛПНП $(r=0,37 ; p<0,05)$, ИМТ $(r=0,36 ; p<0,05)$, ДАД $(r=0,44 ; p<0,05)$, САД $(r=0,38$; $p<0,05)$.

При анализе показателей ЭхоКГ в обеих группах больных было выявлено достоверное увеличение размеров левого предсердия (РЛП) по сравнению с контрольной группой, однако между группами пациентов с АГ статистически значимых различий не обнаружено. Вместе с тем показатель толщины межжелудочковой перегородки (ТМЖП) у пациентов с АГ при коморбидной патологии (2-я группа) был выше не только контрольного значения, но и аналогичного показателя 1-й группы. Гипертрофия миокарда Лж была выявлена у 11 (25\%) пациентов 1-й группы и у $17(40,5 \%)$ пациентов 2-й группы $\left(X^{2}=1,19 ; p=0,27\right)$. Среднее значение индекса массы миокарда левого желудочка (ИММЛЖ) у больных с коморбидной патологией оказалось незначительно выше аналогичного показателя у больных АГ с нормальной функцией щитовидной железы. При этом выявленная корреляционная связь между уровнем ИММЛЖ и уровнем ТТГ $(\mathrm{r}=0,27 ; p<0,05)$ была слабой. Уровень РЛП также слабо коррелиро- вал с уровнем ТТГ ( $r=0,20 ; p<0,05)$. Отмечена прямая корреляционная зависимость средней силы между уровнем ТМЖП и уровнями САД ( $r=0,43$; $p<0,05)$; ДАД ( $r=0,54 ; p<0,05)$; ТТГ $(r=0,35 ; p<0,05)$; OXC $(r=0,45 ; p<0,05)$; ТГ $(r=0,52 ; p<0,05)$; ЛПНП $(r=0,52 ; p<0,05)$; KA $(r=0,47 ; p<0,05)$; ИМТ $(r=0,50$; $p<0,05)$.

Наиболее ранним маркером развития атеросклеротических поражений сонных артерий является утолщение комплекса интимы-медии. Утолщение интимы-медии (ТИМ) сонных артерий выявлено у $26(59,1 \%)$ больных АГ, среднее значение составило $(0,936 \pm 0,203)$ мм, и у $27(64,3 \%)$ больных коморбидной патологией, среднее значение - $(0,996 \pm 0,145)$ мм по сравнению с контрольной группой - $(0,802 \pm 0,087)$ мм. Как видно из табл. 2, в обеих группах были выявлены признаки атеросклеротического поражения экстракраниальных отделов брахиоцефальных артерий (БЦА) - повышение ее эхогенности, наличие атеросклеротических бляшек. У больных коморбидной патологией деформации БЦА были более выраженными по сравнению с больными АГ и контрольной группой $(p<0,05)$.

Выявлены прямые корреляционные связи между ТИМ ОСА и ТГ $(\mathrm{r}=0,30 ; p<0,05)$, ЛПНП $(\mathrm{r}=0,35 ; p<0,05)$ и обратная корреляционная связь с ЛПВП ( $r=-0,25$; $p<0,05)$. Также установлены корреляционные связи между уровнем ТТГ и уровнем ТИМ ОСА ( $r=0,33$; $p<0,05)$. Уровень ТМЖП коррелировал с уровнями ТИМ ОСА $(r=0,47 ; p<0,05)$ и ТИМ ВСА $(r=0,45$; $p<0,05)$.

Высокочувствительный СРБ является независимым предиктором риска развития сердечнососудистых заболеваний (ССЗ) и осложнений. Результаты исследования установили, что уровень вч-СРБ у 86 обследуемых лиц в целом колебался от 0,770 до 9,000 мг/л; у лиц контрольной группы — от 0,300 до 1,000 мг/л. Уровень вч-СРБ в группе больных АГ составил в среднем $(5,016 \pm 2,684)$ мг/л, при коморбидной патологии - $(6,388 \pm 2,178)$ мг/л $(p=0,011)$; у лиц контрольной группы - $(0,608 \pm 0,175) \mathrm{Mr/л}$ $\left(p_{1-3}<0,001, p_{2-3}<0,001\right)$ (табл. 2).

Согласно концепции атерогенеза, атеросклероз - это длительное хроническое воспаление в

Таблица 2

Сравнительная характеристика степени стеноза брахиоцефальных артерий

\begin{tabular}{|l|c|c|c|c|}
\hline \multicolumn{1}{|c|}{ Показатель } & $\begin{array}{c}\text { АГ } \\
\text { (1-я группа) }\end{array}$ & $\begin{array}{c}\text { АГ+СГ } \\
(2-я \text { группа })\end{array}$ & $\begin{array}{c}\text { Контроль } \\
\text { (3-я группа) }\end{array}$ & $p$ \\
\hline Степень стеноза ОСА, \% & $26,36 \pm 8,393$ & $27,76 \pm 6,398$ & - & $p_{1-2}=0,386$ \\
\hline ТИМ ОСА, мм & $0,936 \pm 0,203$ & $0,996 \pm 0,145$ & $0,802 \pm 0,087$ & $\begin{array}{l}p_{1-2}=0,123 \\
p_{1-3}=0,002 \\
p_{2-3}<0,001\end{array}$ \\
\hline Степень стеноза ВСА, \% & & & & $p_{1-2}=0,251$ \\
\hline ТИМ ВСА, мм & $28,00 \pm 5,322$ & $30,71 \pm 14,57$ & - & $p_{1-2}=0,119$ \\
$p_{1-3}=0,625$ \\
$p_{2-3}=0,011$
\end{tabular}

Примечание: $p$ - показатель достоверности различий между группами; ТИМ - толщина интимы-медии; ОСА - общая сонная артерия; ВСА - внутренняя сонная артерия. 
интиме сосуда, что в определенной степени объясняет корреляционную связь между содержанием вч-СРБ и фракторами риска развития атеросклероза: OXC $(r=0,58 ; p<0,05)$, ТГ $(r=0,47 ; p<0,05)$, ЛПНП $(r=0,59 ; p<0,05)$, КА $(r=0,62 ; p<0,05)$, ИМТ $(\mathrm{r}=0,52 ; p<0,05)$, САД $(\mathrm{r}=0,55 ; p<0,05)$, ДАД $(r=0,46$; $p<0,05)$.

Для оценки сердечно-сосудистого риска (ССР) смерти у обследуемых нами пациентов использовались шкалы SCORE и Reynolds.

При оценке CCP по шкале SCORE нами получены следующие результаты: в 1-й группе ССР был низким у 41 (93,2\%) больного, повышенным у $3(6,8 \%)$ больных, больных высокого и очень высокого риска не выявлено. Среди больных с коморбидной патологией низкий ССР отмечен у 33 (78,6\%) пациентов, повышенный риск - у 8 (19\%) больных, высокий ССР - у 1 (2,4\%) больного. Больных с очень высоким ССР не выявлено. Среднее значение риска по шкале SCORE у больных АГ составило $(0,477 \pm 0,628) \%$; у больных АГ в сочетании с СГ - $(0,878 \pm 1,435) \%(p=0,095)$, что соответствует низкому ССР. При использовании шкалы Reynolds получены результаты, демонстрирующие более высокий риск: ССР был низким у $4(9,1 \%)$ больных АГ, умеренно низкий ССР - у $9(20,4 \%)$ больных, умеренно высокий ССР - у 28 (63,7\%) пациентов, высокий ССР - у $3(6,8 \%)$ больных. При коморбидной патологии ССР был низкий у $2(4,8 \%)$ больных, умеренно низкий ССР - у 6 $(14,3 \%)$ пациентов, умеренно высокий ССР - у 31 (73,8\%) больного, высокий ССР - у 3 (7,1\%) пациентов. По шкале Reynolds CCP у больных АГ составил $(11,63 \pm 4,89) \%$, у больных с коморбидной патологией - $(15,52 \pm 4,75) \%$, что свидетельствует об умеренно высоком ССР, $p<0,05$.

Таким образом, субклинический гипотиреоз сопровождается изменениями липидного спектра и, как следствие, предрасполагает к более раннему развитию сердечно-сосудистых осложнений у больных АГ.

\section{Выводы:}

1. При коморбидной патологии отмечена тенденция к более выраженным структурным изменениям сердца и сосудов: утолщению комплекса интимымедии $(p=0,123)$ и гипертрофии левого желудочка $(p=0,27)$, чем у больных АГ без СГ.

2. Установлено, что у больных артериальной гипертензией в сочетании с субклиническим гипотиреозом отмечается более значимое повышение концентрации вч-СРБ $(p=0,011)$ в крови. Содержание вч-СРБ положительно коррелирует с уровнем САД $(p<0,05)$, ДАД $(p<0,05)$, толщиной интимымедии общей сонной артерии $(p<0,05)$, индексом массы тела $(p<0,05)$, ТТГ $(p<0,05)$, показателями липидного профиля: OXC $(p<0,05)$, ЛПНП $(p<0,05)$, ТГ $(p<0,05)$.

3. При прогнозировании 10-летнего риска развития сердечно-сосудистых осложнений у пациентов с АГ информативно использование шкалы Reynolds. При коморбидной патологии лиц с умеренно высоким абсолютным сердечно- сосудистым риском по шкале Reynolds больше, чем при АГ с нормальной функцией щитовидной железы в 1,33 раза.

\section{ЛИТЕРАТУРА}

1. Оганов, Р.Г. Стратегии профилактики сердечнососудистых заболеваний в Российской Федерации / Р.Г. Оганов, Г.Я. Масленникова // Клиническая медицина. - 2012. — № 3. - С.4-7.

2. Балаболкин, М.И. Фундаментальная и клиническая тиреоидология: руководство / М.И. Балаболкин, Е.М. Клебанова, В.М. Креминская. - М.: Медицина, 2007. - $816 \mathrm{c}$.

3. Петунина, Н.А. Использование препаратов гормонов щитовидной железы в клинической практике / Н.А. Петунина. - Петрозаводск: ИнтелТек, 2003. $48 \mathrm{c}$.

4. Бакирова, Н.М. Факторы риска сердечно-сосудистых осложнений и состояние липидного обмена у пожилых больных артериальной гипертензией при различных интервалах уровня тиреотропного гормона гипофиза / Н.М. Бакирова, А.О. Поздняк // Практическая медицина. - 2010. - Т. 43, № 4. - С.112-117 (Казань).

5. Вельков, В.В. С-реактивный белок и липопротеинассоциированная фосфолипаза А2: новые факты и новые возможности для диагностики и стратификации сердечно-сосудистых рисков / В.В. Вельков // Клинико-лабораторный консилиум. - 2009. - Т. 31, № $6 .-$ C.28-33.

\section{REFERENCES}

1. Oganov, R.G. Strategii profilaktiki serdechno-sosudistyh zabolevanii $\vee$ Rossiiskoi Federacii [The strategy of prevention of cardiovascular diseases in the Russian Federation] / R.G. Oganov, G.Ya. Maslennikova // Klinicheskaya medicina [Clinical medicine]. — 2012. № 3. $-\mathrm{S} .4-7$.

2. Balabolkin, M.I. Fundamental'naya i klinicheskaya tireoidologiya: rukovodstvo [Fundamental and clinical tireoidologiya: management] / M.I. Balabolkin, E.M. Klebanova, V.M. Kreminskaya. - M.: Medicina, 2007. - $816 \mathrm{~s}$

3. Petunina, N.A. Ispol'zovanie preparatov gormonov schitovidnoi zhelezy $\vee$ klinicheskoi praktike [Use of preparations of hormones of a thyroid gland in clinical practice] / N.A. Petunina. - Petrozavodsk: IntelTek, 2003. $-48 \mathrm{~s}$

4. Bakirova, N.M. Faktory riska serdechno-sosudistyh oslozhnenii i sostoyanie lipidnogo obmena u pozhilyh bol'nyh arterial'noi gipertenziei pri razlichnyh intervalah urovnya tireotropnogo gormona gipofiza [The risk factors of cardiovascular complications and a condition of a lipidic exchange at elderly patients with arterial hypertension at various intervals of level of a tireotropny hormone of a hypophysis] / N.M. Bakirova, A.O. Pozdnyak // Prakticheskaya medicina [Applied medicine]. - 2010. T. 43, № 4. - S.112-117 (Kazan').

5. Vel'kov, V.V. S-reaktivnyi belok i lipoproteinassociirovannaya fosfolipaza A2: novye fakty i novye vozmozhnosti dlya diagnostiki i stratifikacii serdechno-sosudistyh riskov [C-reactive protein and lipoprotein-associated phospholipase A2: new facts and new possibilities for diagnosis and stratification of cardiovascular risk] / V.V. Vel'kov // Kliniko-laboratornyi konsilium [Klinikolaboratorny consultation]. - 2009. - T. 31, № 6. S.28-33. 


\title{
ФАКТОРЫ РИСКА РАЗВИТИЯ ИНФИЦИРОВАНИЯ МИКОБАКТЕРИЯМИ ТУБЕРКУЛЕЗА ДЕТЕЙ, ПРОЖИВАЮЩИХ В СЕЛЬСКОЙ МЕСТНОСТИ
}

\author{
ТАТЬЯНА ГЕНРИЕВНА ПОДКОПАЕВА, канД. мед. наук, врач-фтизиатр детской консультации \\ БУЗОО «Любинская ЦРБ», Омская область, Россия, тел. 8-913-679-10-89, e-mail: genrievna@mail.ru \\ АННА АНАТОЛЬЕВНА ТУРИЦА, канд. мед. наук, доцент кафедры пропедевтики детских болезней \\ и поликлинической педиатрии ГБОУ ВПО «Омская государственная медицинская академия» Минздрава России, \\ Омск, Россия, тел. 8-913-961-69-25, e-mail: turi8282@mail.ru \\ ЕВГЕНИЯ СЕРГЕЕВНА ЛЕОНТЬЕВА, орДинатор кафедры фтизиатрии и фтизиохирургии \\ ГБОУ ВПО «Омская государственная медицинская академия» Минздрава России, Омск, Россия, \\ тел. 8-908-110-24-34, e-mail: les1490@mail.ru
}

ГУЛЬМИРА ЖАКСЛЫКОВНА САГАЛБАЕВА, ординатор кафедры фтизиатрии и фтизиохирургии ГБОУ ВПО «Омская государственная медицинская академия» Минздрава России, Омск, Россия, тел. 8-951-414-61-49, e-mail: miranda-med@mail.ru

ПАВЕЛ НИКОЛАЕВИЧ ГЕРАСИМОВ, аспирант кафедры фтизиатрии и фтизиохирургии ГБОУ ВПО «Омская государственная медицинская академия» Минздрава России, Омск, Россия, тел. 8-913-069-23-93, e-mail: pavgerasimov@mail.ru

Реферат. Цель исследования — выявление факторов риска развития первичного инфицирования МБТ детей и подростков, проживающих в сельской местности, для совершенствования профилактических мероприятий. Материал и методы. Проведено проспективное сравнительное исследование, в которое включено 269 детей, состоящих на диспансерном учете у фтизиатра по VIA группе учета, находившихся в раннем периоде первичной туберкулезной инфекции, и 269 детей, не инфицированных МБТ, проживавших на территории Любинского района Омской области. Результаты и их обсуждение. При оценке фракторов риска установили, что в группе впервые инфицированных детей достоверно чаще отмечался контакт с больным туберкулезом $\left(x^{2}=101,168\right.$; $p=0,000)$, они чаще проживали в социально дезадаптированных или социопатических семьях, интернате, общежитии, в условиях материального достатка ниже прожиточного минимума $\left(\mathrm{X}^{2}=72,983 ; p=0,000\right)$. При проведении дисперсионного анализа с ранжированием его результатов установлено, что основными фракторами риска инфицирования МБТ детей в условиях села являются: неблагополучный социальный статус семьи, в которой проживал ребенок ( $\mathrm{F}=181,2 ; p=0,000$, ранг 1); низкий материальный достаток семьи ( $\mathrm{F}=33,45 ; p=0,000$, ранг 2); контакт с больным туберкулезом ( $F=11,23 ; p=0,000$, ранг 3). Заключение. В развитии первичного инфицирования МБТ у детей, проживающих в селе, играл роль комплекс социальных и эпидемиологических фракторов, с наибольшей значимостью социальных фракторов и неизвестном диспансеру контакте с больными туберкулезом.

Ключевые слова: инфицирование МБТ, фракторы риска, дети, сельская местность.

\section{RISK FACTORS OF MYCOBACTERIUM TUBERCULOSIS INFECTION IN CHILDREN LIVING IN RURAL AREAS}

TATIANA G. PODKOPAEVA, Ph.D., phthisiatrician, Omsk, Russia, tel. 8-913-679-10-89, e-mail: genrievna@mail.ru ANNA A. TURITSA, Ph.D., associate professor of Department of outpatient pediatrics of SBEI HPE "Omsk State Medical Academy» of Russian Ministry of Health, Omsk, Russia, tel. 8-913-961-69-25, e-mail: turi8282@mail.ru EVGENIYA S. LEONTIEVA, resident of Department of tuberculosis and surgery of SBEI HPE "Omsk State Medical Academy» of Russian Ministry of Health, Omsk, Russia, tel. 8-908-110-24-34, e-mail: les1490@mail.ru GULMIRA ZH. SAGALBAEVA, resident of Department of tuberculosis and surgery of SBEI HPE «Omsk State Medical Academy» of Russian Ministry of Health, Omsk, Russia, tel. 8-951-414-61-49, e-mail: miranda-med@mail.ru PAVEL N. GERASIMOV, graduate student of Department of tuberculosis and surgery of SBEI HPE «Omsk State Medical Academy» of Russian Ministry of Health, Omsk city, Russia, tel. 8-913-069-23-93, e-mail: pavgerasimov@mail.ru

\begin{abstract}
Aim. To identify risk factors for primary M. tuberculosis development in children and adolescents living in rural areas, and to improve prevention measures. Material and methods. A prospective comparative study included 269 children from VIA accounting group in TB dispensary register, who were in the early period of primary TB infection, and 269 not infected children living in the Lyubinsky territory Omsk region. Results. When we assessed the risk factors we found that the group of newly infected children had significantly more contacts with TB patients $\left(X^{2}=101,168\right.$; $p=0,000$ ), they are more likely to live in socially maladjusted or sociopathic families, boarding schools, in families with low income below the subsistence minimum $\left(x^{2}=72,983 ; p=0,000\right)$. An analysis of variance with ranking showed that the main risk factors for $\mathrm{M}$. tuberculosis infection in countryside children were: maladjusted social status of the family $(\mathrm{F}=181,2 ; p=0,000$, rank 1); low income of the family $(\mathrm{F}=33,45 ; p=0,000$, rank 2$)$; contacts with TB patients $(\mathrm{F}=11,23$; $p=0,000$, rank 3). Conclusion. In the development of primary M. tuberculosis infection in children living in the village, prevailed a set of social and epidemiological factors with the greatest significance of social factors and unknown dispensary contact with TB patients.

Key words: M. tuberculosis infection, risk factors, children, countryside.
\end{abstract}


- есмотря на снижение заболеваемости и смертности от туберкулеза, в ряде федеральных округов эпидемическая ситуация сохраняет напряженность, к таким округам относится и Сибирский федеральный округ [3, 4, 7]. В настоящее время практически на прежнем уровне, без выраженной тенденции к снижению, сохраняются показатели детской и подростковой заболеваемости [1, 11], туберкулез у детей и подростков продолжает являться серьезной проблемой фттизиатрии [1, 10]. Многие авторы это связывают с совершенствованием диагностики, внедрением Диаскинтеста и предполагают улучшение структуры клинических фрорм у больных туберкулезом детей $[2,12]$. Вместе с тем у детей встречаются тяжелые генерализованные формы туберкулеза, врожденный туберкулез $[4,6]$.

Для улучшения ситуации среди детей и подростков необходимо совершенствовать мероприятия, направленные на раннее выявление туберкулеза и предупреждение его развития $[7,8,10]$. Применительно к детям и подросткам необходимо заниматься не только профилактикой развития его локальных форм, но и предупреждением развития первичного инфицирования микобактериями туберкулеза (МБТ) $[5,8]$. Однако выявление факторов риска и особенностей течения туберкулезной инфекции большинством врачей и исследователей проводится у детей и подростков, проживающих в городах [9]. Знание фракторов риска инфицирования МБТ позволит оптимизировать профилактические мероприятия, в том числе и у детей, проживающих в сельской местности.

Цель исследования - выявление фракторов риска развития первичного инфицирования МБТ детей и подростков, проживающих в сельской местности, для совершенствования профилактических мероприятий.

Материал и методы. Проведено проспективное сравнительное исследование, в которое включено 269 детей, состоящих на диспансерном учете у фртизиатра по VIA группе учета, находившихся в раннем периоде первичной туберкулезной инфекции, проживающих на территории Любинского района
Омской области, и группы сравнения, в которую вошли не инфицированные МБТ дети (269 человек), находящихся под наблюдением участковых педиатров БУЗОО «Любинская ЦРБ». Обязательным критерием включения в исследование было наличие информированного согласия родителей или законных представителей ребенка. При изучении факторов риска первичного инфицирования МБТ оценивались эпидемиологические, социальные и гигиенические факторы.

Полученные в ходе исследования данные статистически обрабатывались с помощью пакета прикладных программ «Microsoft Office 2007», Biostat 2009. Различия между группами определялись с использованием критерия $X^{2}$, считались достоверными при $p<0,05$. Для оценки силы и достоверности влияния факторов на развитие инфицирования у детей использовали дисперсионный анализ с ранжированием результатов.

Результаты и их обсуждение. Согласно представленным в табл. 1 данным, в группе детей в РППТИ в 12 раз чаще был установлен источник заражения ребенка, чем в группе сравнения $\left(X^{2}=101,168\right.$; $p=0,000)$. У детей основной группы в $10 \%$ случаев отмечался тесный семейный контакт. Реже наблюдался периодический контакт с родственниками, совместно не проживающими с ребенком $(6,7 \%)$. Кратковременный контакт регистрировался с частотой 2,2\% случаев. Также у $10 \%$ детей регистрировали производственный контакт по месту пребывания в детских дошкольных учреждениях, школах. Таким образом, подтверждается мнение об определяющей роли эпидемиологического фактора в развитии раннего периода первичной туберкулезной инфекции у детей [9].

Результаты оценки эффрективности вакцинации БЦЖ в группах сравнения представлены в табл. 2. Bce дети, находившиеся в РППТИ (n=269), были вакцинированы против туберкулеза. При этом вакцинация оказалась эффективной у большинства детей $(68,8 \%)$. В основной группе детей средний размер сорормированного рубца на месте введения вакцины БЦЖ составил $(4,4 \pm 0,1)$ мм, в группе сравнения $(4,3 \pm 0,3)$ мм.

Таблица 1

Эпидемиологические факторы в изучаемых группах

\begin{tabular}{|l|c|c|}
\hline \multicolumn{2}{|c|}{ Факторы } & \multicolumn{2}{c|}{ Группы } \\
\cline { 2 - 3 } & Дети в РППТИ, $n(\%)$ & Не инфицированные МБТ, $n$ (\%) \\
\hline Наличие контакта с больным туберкулезом & $18(6,7 \%)$ & $4(1,5 \%)^{*}$ \\
\hline Бытовой & $27(10 \%)$ & $2(0,7 \%)^{*}$ \\
\hline Семейный & $27(10 \%)$ & 0 \\
\hline Производственный (по месту пребывания детей) & $6(2,2 \%)$ & $4(1,5 \%)$ \\
\hline Кратковременный контакт в анамнезе & $72(26,8 \%)$ & $6(2,2 \%)$ \\
\hline Всего & $35(13 \%)$ & 0 \\
\hline Наблюдение по контакту на момент исследования & $34(12,6 \%)$ & 0 \\
\hline Выявлен одновременно с очагом туберкулезной инфекции & \\
\hline
\end{tabular}

Примечание: "достоверные различия в группах сравнения, критерий $\chi^{2}, p \leq 0,05$. 
Эффективность вакцинации БЦЖ в группах сравнения

\begin{tabular}{|c|c|c|c|c|c|c|c|c|c|}
\hline \multirow[t]{2}{*}{ Группа } & \multicolumn{2}{|c|}{$\begin{array}{c}\text { Вакцинировано } \\
\text { БЦж }\end{array}$} & \multicolumn{2}{|c|}{$\begin{array}{c}\text { Эффрективная } \\
\text { вакцинация }\end{array}$} & \multicolumn{2}{|c|}{$\begin{array}{c}\text { Малоэфффективная } \\
\text { вакцинация }\end{array}$} & \multicolumn{2}{|c|}{$\begin{array}{c}\text { Неэфрфективная } \\
\text { вакцинация }\end{array}$} & \multirow{2}{*}{$x^{2}, p$} \\
\hline & Абс. & $\%$ & Абс. & $\%$ & Абс. & $\%$ & Абс. & $\%$ & \\
\hline Дети в РППТИ, $n=269$ & 269 & 100 & 185 & 68,8 & 78 & 29 & 6 & 2,2 & \multirow{2}{*}{$\begin{array}{l}x^{2}=1,204 \\
p=1,000\end{array}$} \\
\hline Неинфиццированные МБТ, $n=269$ & 269 & 100 & 188 & 70 & 73 & 27 & 8 & 2,9 & \\
\hline
\end{tabular}

Характеристика социального статуса семей у детей в сравниваемых группах

\begin{tabular}{|c|c|c|c|}
\hline \multirow{2}{*}{ Социальный статус семьи } & \multicolumn{3}{|c|}{ Группы сравнения } \\
\hline & Дети в РППТИ, $n=269$ & Неинфицированные МБТ дети, $n=269$ & $x^{2} p$ \\
\hline Социально-сохранные семьи & 98 & 137 & \multirow{3}{*}{$\begin{aligned} x^{2} & =13,247 \\
p & =0,001\end{aligned}$} \\
\hline Социально дезадаптированные семьи & 105 & 83 & \\
\hline Социопатические семьи & 68 & 46 & \\
\hline
\end{tabular}

Таблица 4

Значимость влияния основных факторов риска на развитие первичного инфицирования МБТ

\begin{tabular}{|l|c|c|c|}
\hline \multicolumn{1}{|c|}{ Исследуемый фактор } & $\mathrm{F}$ & P & Ранг \\
\hline Социальный статус - социально дезадаптированные и социопатические семьи & 181,2 & 0,000 & 1 \\
\hline Низкий материальный достаток & 33,45 & 0,000 & 2 \\
\hline Контакт с больным туберкулезом & 11,24 & 0,000 & 3 \\
\hline Благоустройство жилья & 2,03 & 0,155 & 4 \\
\hline
\end{tabular}

Примечание: однофракторный дисперсионный анализ, F-критерий Фишера (Fisher).

Принадлежность детей из групп сравнения к различным в социальном отношении семьям представлена в табл. 3. На основании данных анамнеза при изучении социального портрета семьи учитывались условия проживания и материальное благополучие семей. Установлено, что наибольшее количество детей из основной группы проживали в социально дезадаптированных $(39 \%)$ и социопатических $(25,3 \%)$ семьях $\left(X^{2}=17,736 ; p=0,000\right)$. При этом большая часть детей из группы сравнения была из социально-сохранных семей $-50,9 \%\left(x^{2}=4,190\right.$; $p=0,041)$.

Сельское население в большей степени проживает в частных домах, при этом основная масса жилья неблагоустроенна: нет возможности иметь централизованное отопление, водоснабжение. Так, по результатам нашего наблюдения дети основной группы проживали в неблагоустроенных условиях только в 44,9\% случаев, в группе сравнения таких детей оказалось достоверно больше - 75,0\% $\left(x^{2}=69,461\right.$; $p=0,000)$, что никак не отразилось на уровне первичного инфицирования МБТ среди этой категории детей. При этом среди детей из основной группы чаще регистрировали проживание в условиях либо интерната, либо общежития $\left(\mathrm{X}^{2}=42,641 ; p=0,000\right)$, что подтверждает наличие высокого риска инфицирования МБТ (закрытые учреждения, проживание в условиях общежития является отягощающим фрактором при определении эпидемиологической опасности) [9]. Анализируя ситуацию, установили, что большая часть детей основной группы проживала в семьях с низким материальным достатком, при этом 47,2\% семей имели доход ниже прожиточного минимума $\left(x^{2}=4,069 ; p=0,044\right)$.

Для оценки силы и достоверности влияния факторов на развитие раннего периода первичной туберкулезной инфекции у детей, проживающих в селе, был использован дисперсионный анализ, результаты которого были проранжированы (табл. 4). Как видно из табл. 4, основными факторами риска инфицирования МБТ детей в условиях села являлись неблагополучный социальный статус семьи, в которой проживал ребенок, низкий материальный достаток семьи, на третьем месте по значимости контакт с больным туберкулезом.

Заключение. Проведенное исследование показало, что в развитии первичного инфицирования МБТ у детей, проживающих в селе, играл роль комплекс социальных и эпидемиологических факторов. Наиболее значимыми для развития первичного инфицирования МБТ оказались социальные факторы. Принадлежность детей к социально дезадаптированным и социопатическим семьям приводило к их более частому заражению туберкулезом при случайных неизвестных фртизиатру контактах с больными туберкулезом. 


\section{ЛИТЕРАТУРА}

1. Аксенова, В.А. Туберкулез у детей в России и задачи фртизиатрической общей педиатрической службы по профилактике и раннему выявлению заболевания / В.А. Аксенова, Л.А. Барышникова, Т.А. Севастьянова, Н.И. Клевно // Туберкулез и болезни легких. — 2014. Т. 91, № 3. - С.40-46.

2. Аксенова, В.А. Актуальные вопросы скрининга детей на туберкулез / В.А. Аксенова, Л.А. Барышникова, Н.И. Клевно [и др.] // Туберкулез и болезни легких. 2013. - T. 90, № 6. - С.7-8.

3. Иванова, О.Г. Эфффективность мероприятий по выявлению туберкулеза органов дыхания в Омской области / О.Г. Иванова, А.В. Мордык, Л.В. Пузырева [и др.] // Кубанский научный медицинский вестник. - 2011. № 4. - С.102-104.

4. Краснов, В.А. Факторы, препятствующие улучшению ситуации по туберкулезу в субъектах Сибирского федерального округа / В.А. Краснов, В.М. Чернышев, О.В. Стрельченко [и др.] // Туберкулез и болезни легких. - 2012. - Т. 89, № 10. - С.8-14.

5. Кривоногова, А.В. Эффрективность туберкулинодиагностики при обследовании школьников в сельской местности / А.В. Кривоногова, Е.А. Амосова, Б.Е. Бородулин // Туберкулез и болезни легких. - 2013. - Т. 90, № $6 .-$ C.50.

6. Лысов, А.В. Клиническое наблюдение врожденного туберкулеза у новорожденного ребенка / А.В. Лысов, А.В. Мордык, М.А. Плеханова [и др.] // Туберкулез и болезни легких. — 2010. - Т. 87, № 4. - С.54-57.

7. Мордык, А.В. Современные международные и национальные концепции борьбы с туберкулезом / А.В. Мордык, Л.В. Пузырева, Л.П. Аксютина // Дальневосточный журнал инфекционной патологии. 2013. — № 22(22). — С.92-97.

8. Мордык, А.В. Противотуберкулезный иммунитет и механизмы его формирования (обзор литературы) / А.В. Мордык, Е.А. Цыганкова, Л.В. Пузырева, А.А. Турица // Дальневосточный медицинский журнал. 2014. — № 1. - С.126-130.

9. Мордык, А.В. Факторы риска развития туберкулеза у детей (обзор литературы) / А.В. Мордык, Е.А. Цыганкова, Т.Г. Подкопаева [и др.] // Жизнь без опасностей. Здоровье. Профилактика. Долголетие. - 2013. - Т. 8 , № 2. - C.92-95.

10. Мордык, А.В. Туберкулез у детей Российской Федерации на современном этапе / А.В. Мордык, Е.А. Цыганкова, Л.В. Пузырева, А.А. Турица // Педиатрическая фрармакология. - 2014. - Т. 11, № 3. - С.27-30.

11. Нечаева, О.Б. Эпидемическая ситуация по туберкулезу среди детей России / О.Б. Нечаева // Туберкулез и болезни легких. - 2013. - Т. 90, № 6. - С.62-63.

12. Поддубная, Л.В. Скрининг туберкулеза в современных условиях / Л.В. Поддубная, Е.П. Шилова, Е.В. Силайкина // Туберкулез и болезни легких. - 2013. - Т. 90, № $6 .-$ C.71-72.

\section{REFERENCES}

1. Aksenova, V.A. Tuberkulez u detei v Rossii i zadachi ftiziatricheskoi obschei pediatricheskoi sluzhby po profilaktike i rannemu vyyavleniyu zabolevaniya [Tuberculosis in children in Russia and the problem of TB general pediatric services for prevention and early detection of the disease] / V.A. Aksenova, L.A. Baryshnikova, T.A. Sevast'yanova, N.I. Klevno // Tuberkulez i bolezni legkih [Tuberculosis and Lung Disease]. - 2014. - T. 91, № 3. $-\mathrm{S} .40-46$.

2. Aksenova, V.A. Aktual'nye voprosy skrininga detei na tuberkulez [Actual questions screening children for tuberculosis] / V.A. Aksenova, L.A. Baryshnikova, N.I. Klevno [l dr.] // Tuberkulez i bolezni legkih [Tuberculosis and Lung Disease]. - 2013. - T. 90, № $6 .-\mathrm{S} .7-8$.

3. Ivanova, O.G. Effektivnost' meropriyatii po vyyavleniyu tuberkuleza organov dyhaniya $v$ Omskoi oblasti [The effectiveness of measures to identify pulmonary tuberculosis in the Omsk region] / O.G. Ivanova, A.V. Mordyk, L.V. Puzyreva [i dr.] // Kubanskii nauchnyi medicinskii vestnik [Kuban Research Medical Gazette]. — 2011. № 4. - S.102-104.

4. Krasnov, V.A. Faktory, prepyatstvuyuschie uluchsheniyu situacii po tuberkulezu v sub'ektah Sibirskogo federal'nogo okruga [Obstacles to improved TB situation in the subjects of the Siberian Federal District] / V.A. Krasnov, V.M. Chernyshev, O.V. Strel'chenko [i dr.] // Tuberkulez i bolezni legkih [Tuberculosis and Lung Disease]. 2012. - T. 89, № 10. - S.8-14.

5. Krivonogova, A.V. Effektivnost' tuberkulinodiagnostiki pri obsledovanii shkol'nikov $v$ sel'skoi mestnosti [The effectiveness of tuberculin diagnostic at inspection of schoolchildren in rural areas] / A.V. Krivonogova, E.A. Amosova, B.E. Borodulin // Tuberkulez i bolezni legkih [Tuberculosis and Lung Disease]. — 2013. - T. 90, № $6 .-\mathrm{S} .50$.

6. Lysov, A.V. Klinicheskoe nablyudenie vrozhdennogo tuberkuleza u novorozhdennogo rebenka [Clinical observation of congenital tuberculosis in a newborn baby] / A.V. Lysov, A.V. Mordyk, M.A. Plehanova [l dr.] // Tuberkulez i bolezni legkih [Tuberculosis and Lung Disease]. — 2010. - T. 87, № 4. S. $54-57$.

7. Mordyk, A.V. Sovremennye mezhdunarodnye i nacional'nye koncepcii bor'by $s$ tuberkulezom [The modern concept of international and national TB control] / A.V. Mordyk, L.V. Puzyreva, L.P. Aksyutina // Dal'nevostochnyi zhurnal infekcionnoi patologii [Far East Journal of Infectious Pathology]. — 2013. — № 22(22). S.92-97.

8. Mordyk, A.V. Protivotuberkuleznyi immunitet i mehanizmy ego formirovaniya (obzor literatury) [TB immunity and the mechanisms of its formation (review)] / A.V. Mordyk, E.A. Cygankova, L.V. Puzyreva, A.A. Turica // Dal'nevostochnyi medicinskii zhurnal [Far East Medical Journal]. - 2014. — № 1. - S.126-130.

9. Mordyk, A.V. Faktory riska razvitiya tuberkuleza u detei (obzor literatury) [Risk factors for tuberculosis in children (review)] / A.V. Mordyk, E.A. Cygankova, T.G. Podkopaeva [i dr.] // Zhizn' bez opasnostei. Zdorov'e. Profilaktika. Dolgo letie [Life without danger. Health. Prevention. Longevity]. 2013. - T. 8, № 2. - S.92-95.

10. Mordyk, A.V. Tuberkulez u detei Rossiiskoi Federacii na sovremennom etape [Tuberculosis in children of the Russian Federation at the present stage] / A.V. Mordyk, E.A. Cygankova, L.V. Puzyreva, A.A. Turica // Pediatricheskaya farmakologiya [Pediatric pharmacology]. — 2014. - T. 11, № 3. - S.2730.

11. Nechaeva, O.B. Epidemicheskaya situaciya po tuberkulezu sredi detei Rossii [Epidemiological situation of tuberculosis among children in Russia] / O.B. Nechaeva // Tuberkulez i bolezni legkih [Tuberculosis and Lung Disease]. - 2013. - T. 90, № 6. - S.62-63.

12. Poddubnaya, L.V. Skrining tuberkuleza v sovremennyh usloviyah [Screening for tuberculosis in modern conditions] / L.V. Poddubnaya, E.P. SHilova, E.V. Silaikina // Tuberkulez i bolezni legkih [Tuberculosis and Lung Disease]. — 2013. — T. 90, № 6. - S.71-72.

Принята 27.08.2014 


\title{
ВОЗМОЖНОСТИ КАРДИОПУЛЬМОНАЛЬНОГО НАГРУЗОЧНОГО ТЕСТИРОВАНИЯ В ОЦЕНКЕ ФИЗИЧЕСКОЙ РАБОТОСПОСОБНОСТИ И ФУНКЦИОНАЛЬНОГО СОСТОЯНИЯ ДЫХАТЕЛЬНОЙ СИСТЕМЫ У ЗДОРОВЫХ ЛИЦ
}

\author{
ЛАРИСА БОРИСОВНА ПОСТНИКОВА, докт. мед. Наук, доцент, главный внештатный пульмонолог МЗ \\ Нижегородской области, руководитель Городского пульмонологического консультативного центра \\ ГБУЗ НО «Городская больница № 28», Нижний Новгород, Россия, тел. (831)-276-84-12, e-mail: plbreath@mail.ru \\ ИВАН АЛЕКСАНДРОВИЧ ДОРОВСКОЙ, врач-терапевт ГБУЗ НО «Городская больница № 28», \\ Нижний Новгород, Россия, тел. (831)-276-84-12, 8-915-958-17-70, e-mail: fiatlux2008@rambler.ru \\ ВЛАДИМИР АЛЕКСАНДРОВИЧ КОСТРОВ, канд. мед. наук, доцент, врач-пульмонолог, консультант \\ ГБУЗ НО «Городская больница № 28», Нижний Новгород, Россия, тел. 8-902-308-24-97, e-mail: vlakostr@yandex.ru \\ ИГОРЬ ВАЛЕНТИНОВИЧ ДОЛБИН, докт. меД. наук, доцент, врач-кардиолог ГБУЗ НО «Городская больница № 38», \\ Нижний Новгород, Россия, тел. 8-910-796-03-21, e-mail: Dolbina.Olesya20@yandex.ru \\ АНДРЕЙ АЛЕКСАНДРОВИЧ ФЕДОРЕНКО, каНД. МЕД. Наук, врач-терапевт ГБУЗ НО «Городская больница № 30 », \\ Нижний Новгород, Россия, тел. 8-904-395-01-17, e-mail: feddoc@rambler.ru
}

\begin{abstract}
Реферат. Нагрузочное тестирование (НT) с измерением показателей газообмена - надежный инструмент, предоставляющий дополнительную диагностическую информацию о работоспособности и функциональном состоянии дыхательной и сердечно-сосудистой систем. Статья посвящена применению кардиопульмонального нагрузочного тестирования (КПНТ) у здоровых молодых мужчин с целью оценки физической работоспособности и функционального состояния дыхательной системы. Представлены основные показатели, оцениваемые в процессе проведения КПНТ, и их физиологическое значение. Обсуждены вопросы методологии и интерпретации результатов КПНТ. Продемонстрированы возможности использования КПНТ у здоровых лиц с различным уровнем ффизической подготовки. Выводы. КПНТ является информативным методом оценки физического здоровья человека. Предложенный модифицированный протокол Вruce для проведения КПНТ в максимальном нагрузочном тесте (с увеличением нагрузки на 50 ВТ каждые 2 мин до отказа) может эффективно использоваться для групповых обследований молодых здоровых мужчин.
\end{abstract}

Ключевые слова: кардиопульмональное нагрузочное тестирование, велоэргометрия, молодые здоровые мужчины.

\section{A CAPABILITY OF CARDIOPULMONARY EXERCISE TESTING IN THE ASSESSMENT OF PHYSICAL HEALTH AND FUNCTIONAL CONDITION OF RESPIRATORY SYSTEM IN HEALTHY PERSONS}

\author{
LARISA B. POSTNIKOVA, IVAN A. DOROVSKOY, VLADIMIR A. KOSTROV, IGOR V. DOLBIN, ANDREY A. FEDORENKO, \\ Nizhny Novgorod, Russia
}

\begin{abstract}
The article examines of the use of cardiopulmonary exercise testing (CPET) in healthy young men to assess physical health and functional condition of respiratory system. The authors presented the main indicators for CPET and analyzed their physiological value. They discussed methodology and interpretation of results CPET. The authors demonstrated own results of CPET in healthy persons.

Key words: cardiopulmonary exercise testing, veloergometry, young healthy men.
\end{abstract}

$\mathrm{H}$ агрузочное тестирование (НT) с измерением показателей газообмена - надежный инструмент, предоставляющий дополнительную диагностическую информацию о работоспособности и функциональном состоянии дыхательной и сердечно-сосудистой систем (ССС), для выявления ограничения работоспособности при отсутствии клинических проявлений, а также уточнения причин фрункциональных нарушений $[1,2]$.

Выделяют два типа НТ: лабораторные высокотехнологичные кардиопульмональные нагрузочные тесты (КПНТ) с использованием дорогостоящего оборудования для оценки функционального состояния кардиореспираторной системы и газообмена и внелабораторные НТ, не требующие специального оборудования [3].
КПНТ — информативный метод, оценивающий реакцию организма человека на фризическую нагрузку, позволяющий при патологии выявить конкретную патофизиологическую причину снижения физической активности [4]. Несмотря на преимущества КПНТ для оценки состояния компенсаторноприспособительных механизмов у здоровых лиц и степени функциональной недостаточности кардиореспираторной системы при различных заболеваниях широкое использование данного метода в клинике ограничивается рядом факторов: сложностью систем КПНТ и их стоимостью, необходимостью специальных знаний, относительно малым числом курсов обучения специалистов $[1,3]$.

В статье рассмотрены основные этапы и параметры, предусмотренные при проведении КПНТ, а 
также представлены протоколы нагрузочного тестирования здоровых молодых мужчин.

Способность к выполнению фризической нагрузки напрямую связана с возможностью ССС обеспечивать ткани кислородом $\left(\mathrm{O}_{2}\right)$, а системы дыхания освобождаться от углекислого газа $\left(\mathrm{CO}_{2}\right)$. Газообмен условно разделяют на три процесса: 1) легочная вентиляция (движение воздуха в легкие и обратно); 2) легочная дифффузия (обмен $\mathrm{O}_{2}$ и $\mathrm{CO}_{2}$ между легкими и кровью); 3) капиллярный газообмен или обмен $\mathrm{CO}_{2}$ между кровью в капиллярах и тканях [5]. Легочная вентиляция обеспечивается активным вдохом и пассивным выдохом. Парциальное давление $\mathrm{O}_{2}$ $\left(\mathrm{PaO}_{2}\right)$ вдыхаемого воздуха составляет около 160 мм рт.ст., $\mathrm{PaCO}_{2}-0,3$ мм рт.ст., а $\mathrm{PaO}_{2}$ крови в легочных капиллярах составляет 40 мм рт.ст., $\mathrm{PaCO}_{2}-45$ мм рт.ст. Разница в градиенте давления в альвеолах обеспечивает дифффузию газов между кровью и воздухом и обогащение крови $\mathrm{O}_{2}$ с $\mathrm{PaO}_{2} 104$ мм рт.ст. при снижении $\mathrm{PaCO}_{2}$ до 40 мм рт.ст. Легочная вентиляция и диффузия - составляющие внешнего дыхания, цель которого перемещение газов из окружающего воздуха в кровь и обратно. Внутреннее дыхание отражает газообмен между тканями организма и кровью. Внешнее и внутреннее дыхание связаны системой кровообращения и обеспечивают транспорт газов кровью [2].

К параметрам, реагирующим на увеличение потребления $\mathrm{O}_{2}$ при фризической нагрузке, относят сердечный выброс (СВ = ЧСС $\times$ ударный объем), минутную вентиляцию (VE), дыхательный объем (ДО). При увеличении потребления $\mathrm{O}_{2}$ работающими мышцами повышение СВ может повышаться в 6 раз. Параллельно с этим кровь перераспределяется от неактивных тканей (селезенка, почки) к скелетным мышцам, что улучшает доставку $\mathrm{O}_{2}$, а также усиливается приток крови к легким вследствие увеличения СВ и вазодилатации легочных сосудов. Дополнительно нарастает экстракция $\mathrm{O}_{2}$ из крови работающими мышцами, что повышает артериовенозную разницу по $\mathrm{O}_{2}$ [2].

У здоровых лиц VE увеличивается пропорционально физической нагрузке. Во время дыхания только часть вдыхаемого воздуха достигает альвеол, где происходит газообмен. Другая часть воздуха остается в дыхательных путях (ДП), не участвующих в газообмене (мертвое пространство — VD). При нагрузке ДП расширяются, а объема VD увеличивается. При этом одновременное увеличение ДО сохраняет альвеолярную вентиляцию и газообмен. Совокупность этих процессов называется нормальным вентиляционноперфузионным соответствием [5].

КПНТ может проводиться на беговой дорожке (тредмил) или велоэргометре (ВЭМ). Выбор методики определяется индивидуально. Беговая дорожка позволяет осуществлять постоянно нарастающую нагрузку через комбинацию увеличения скорости и роста угла наклона поверхности $[3,6]$. Протоколы с постоянной нагрузкой приобретают все большую популярность из-за удобства мониторирования ответа кардиореспираторной системы на терапию, анализа динамической вентиляции и кинетики газообмена [7].
КПНТ, проводимое на тредмиле, имеет ряд преимуществ перед ВЭМ. Для многих людей беговая дорожка является более привычной формой упражнений. Ходьба и бег требует вовлечения в работу всех мышц и приводит к большей нагрузке на все органы. Вследствие этого максимальное потребление $\mathrm{O}_{2}$ на 5-10\% выше на беговой дорожке, чем на ВЭМ. Основной недостаток тредмил-теста это трудности точного подсчета внешней нагрузки на человека при физическом усилии в связи с влиянием массы тела.

ВЭМ предпочтительней у людей с нарушением походки или равновесия, при ожирении, ортопедических нарушениях, одновременном ультразвуковом исследовании сердца. Велоэргометр требует меньше пространства для проведения исследования, его стоимость ниже, а использование создает меньшее число артефрактов при записи ЭКГ. Современные велоэргометры с электронной системой тормозов обеспечивают одинаковый уровень физической нагрузки при различной скорости кручения педалей. При нарушении функций нижних конечностей можно использовать ручную эргометрию $[5,8]$.

Современные системы КПНТ позволяют анализировать газообмен в состоянии покоя, во время нагрузки, в период восстановления и измеряют следующие основные показатели в течение каждого дыхательного цикла: потребление $\mathrm{O}_{2}$, максимальное потребление $\mathrm{O}_{2}$, продукция $\mathrm{CO}_{2}$, частота респираторного обмена, максимальная аэробная производительность (METS), минутная вентиляция, время нагрузки и наступления анаэробного порога, частота сердечных сокращений, артериальное давление.

1. Потребление кислорода $\left(\mathrm{Vo}_{2}\right)-$ уровень $\mathrm{O}_{2}$, потребляемый организмом каждую минуту, рассчитывается по минутной вентиляции и концентрации $\mathrm{O}_{2}$ на вдохе и выдохе, стандартизируется по температуре $(\mathrm{t})$ тела $\left(37^{\circ} \mathrm{C}\right)$, t окружающей среды $\left(0^{\circ} \mathrm{C}\right)$, барометрическому давлению (101,3 кПа) при нулевой влажности [1, 4]. В норме $\mathrm{Vo}_{2}$ увеличивается линейно при повышении внешней нагрузки [5], точно измеряемое на велоэргометре, но лишь приблизительно - на беговой дорожке. Кривая $\mathrm{Vo}_{2}$ - внешняя нагрузка - отражает эффрективность метаболизма и преобразования потенциальной химической энергии в механическую работу и позволяет оценить общую механическую эффрективность мышечно-скелетной системы [4].

2. Максимальное потребление кислорода (Vo, max) определяет границы возможностей CCC при пиковой нагрузке. Определяется уравнением Фика как результат СВ и артериовенозной разницы по $\mathrm{O}_{2}: \mathrm{Vo}_{2} \max =($ ЧCC $\times$ ударный объем $) \times \mathrm{SaO}_{2}$, где $\mathrm{SaO}_{2}$ - сатурация $\mathrm{O}_{2}$, измеряется в литрах $\mathrm{O}_{2}$ в мин, но обычно выражается в мл $\mathrm{O}_{2}$ на 1 кг массы тела в мин [1]. Измерение $\mathrm{Vo}_{2} \max$ подразумевает, что достигнут максимальный физиологический предел (или максимальный аэробный предел) для данного индивидуума. Истинная $\mathrm{Vo}_{2} \max$ обычно определяется как график $\mathrm{Vo}_{2}$ между двумя фринальными уровнями нагрузки и требует достижения и поддержания максимального усилия в течение определенного 
времени. Vo max редко наблюдается у пациентов с сердечно-сосудистыми или легочными заболеваниями, и в связи с этим для описания нагрузочной возможности в клинике чаще используется пиковая $\mathrm{Vo}_{2}$. Показатель $\mathrm{Vo}_{2} \max$, прежде всего, оценивают у спортсменов, когда достижение максимального физиологического ответа является наиболее вероятным. Значение Vo, max может увеличиваться от 3,5 мл/мин/кг в состоянии покоя до 30-50 мл/мин/кг при физической нагрузке. У спортсменов при нагрузке его значение может возрастать в 20 раз (до 80 мл/ мин/кг)

3. Продукция углекислого газа $\left(\mathrm{Vco}_{2}\right)-$ количество $\mathrm{CO}_{2}$, вырабатываемое организмом каждую минуту, рассчитывается с учетом концентрации $\mathrm{CO}_{2}$ на вдохе и выдохе. При непродолжительной нагрузке основным источником энергии является гликоген, и взаимосвязь между потреблением $\mathrm{O}_{2}$ и продукцией $\mathrm{CO}_{2}$ практически эквимолярна. При нарастающем увеличении нагрузки $\mathrm{Vco}_{2}$ увеличивается в той же мере, что и $\mathrm{Vo}_{2}$, и соотношение $\mathrm{Vco}_{2} / \mathrm{Vo}_{2}$ остается немногим меньше единицы. При достижении анаэробного предела обычно наблюдается резкое изменение угла наклона кривой $\mathrm{Vco}_{2} / \mathrm{Vo}_{2}$, однако зависимость сохраняет линейный характер. Более крутой угол наклона кривой означает большую выработку $\mathrm{CO}_{2}$ по сравнению с потреблением $\mathrm{O}_{2}$ при включении анаэробных механизмов. Избыточное количество $\mathrm{Vco}_{2}$ в выдыхаемом воздухе также может быть результатом «вымывания» $\mathrm{CO}_{2}$ из-за гипервентиляции [4].

4. Частота респираторного обмена $\left(\mathrm{Vco}_{2} / \mathrm{Vo}_{2}\right)$, (RER, отн. ед.) дыхательный коэффицциент $(\mathrm{R}, \mathrm{RC})$ параметр, позволяющий оценить вклад системы энергообеспечения (аэробной и/или анаэробной) при выполнении КПНТ и отражает зависимость объема выделенного $\mathrm{CO}_{2}$ к объему потребленного $\mathrm{O}_{2}$. Значение RER больше 1 может быть вызвано увеличением выработки $\mathrm{CO}_{2}$ из молочной кислоты или избыточной продукцией $\mathrm{CO}_{2}$ вследствие гипервентиляции, (когда концентрация $\mathrm{CO}_{2}$ в выдыхаемом воздухе повышается за счет уменьшения его уровня в крови). Пиковое значение RER является надежным и точным маркером усилий конкретного индивидуума. RER более 1,1 расценивается как показатель очень значительных усилий во время КПНТ, но не является показанием к прекращению исследования. Значение RER менее 1,0 при прекращении исследования по просьбе пациента при отсутствии ЭКГ и гемодинамических нарушений указывает на субмаксимальный уровень сердечнососудистой нагрузки [4].

5. Максимальная аэробная производительность может быть выражена в метаболических единицах (METS). Одна METS соответствует энергетическому обмену в покое со средним потреблением О 2 3,5 мл/ мин/кг. Соответственно могут быть рассчитаны значения максимального энергетического обмена у людей с различным уровнем физической подготовленности: пациенты — 5 METS; нетренированные 10 METS; тренированные спортсмены - 15 METS; высокотренированные спортсмены - 20 METS и выше [1, 5].
6. Время наступления порога анаэробного обмена (ПАНО, мин) - интегральный показатель работоспособности, характеризующий аэробную производительность. Наиболее часто ПАНО считают момент, когда $\mathrm{Vo}_{2}$ становится равен $\mathrm{Vco}_{2}$ на фоне нагрузки. В среднем диапазоне работы $\mathrm{Vco}_{2}$ увеличивается более резко, чем $\mathrm{Vo}_{2}$, что влияет на накопление молочной кислоты свыше порога лактацидоза. Вследствие этого анаэробный порог (АТ или ПАНО) часто называют лактатным. Согласно теории К. Вассермана (1973), на уровне ПАНО коэфффициент R равен 1,0 (рис. 1).

Другим способом определения наступления ПАНО является изменение характера зависимости дыхательного эквивалента для $\mathrm{O}_{2}\left(\mathrm{EQO}_{2}\right)$ и $\mathrm{CO}_{2}$ $\left(\mathrm{EQCO}_{2}\right)$. Этот показатель отражает количество воздуха VE, необходимое для вдыхания 1 л О, или выдоха 1 л $\mathrm{CO}_{2}$. До наступления анаэробного порога $\mathrm{EQO}_{2}=\mathrm{VE} / \mathrm{Vo}_{2}$ и имеет незначительные колебания в начале нагрузки. Однако при аэробно-анаэробном переходе график зависимости EQO, начинает резко расти и его значение после ПАНО описывается следующей формулой: $\mathrm{EQO}_{2}=(\mathrm{VE}-\mathrm{VDa} \times \mathrm{Rf}) / \mathrm{Vo}_{2}$, где $\mathrm{VDa}$ - мертвое альвеолярное пространство (мл), $\mathrm{Rf}$ - частота дыхания (1/мин), $\mathrm{Vo}_{2}$ - потребление $\mathrm{O}_{2}$ (мл/мин) $[1,4,5,7]$.

Следовательно, при увеличении нагрузки до максимальных величин вентиляция легких повышается непропорционально потреблению $\mathrm{O}_{2}$, т.е. наступает момент снижения эффективности вентиляции легких. Системное увеличение EQO щего повышения $\mathrm{EQCO}_{2}$ является специфическим критерием оценки анаэробного порога, так как постоянство вентиляционного эквивалента по $\mathrm{CO}_{2}$ свидетельствует о соответствии вентиляции потребности организма в выведении $\mathrm{CO}_{2}$ (рис. 2).

Таким образом, в настоящее время наиболее часто используемым и научно обоснованным подходом определения времени наступления анаэробного вентиляционного порога (точки респираторной компенсации, RC) при выполнении КПНТ является момент нелинейного увеличения показателя VE и соответствующий ему момент системного увеличения $\mathrm{EQO}_{2}$ без сопутствующего повышения $\mathrm{EQCO}_{2}$.

7. Минутная вентиляция (VE) - исследование вентиляционной функции легких, выполненное до КПНТ, дает основание для анализа исходных паттернов дыхания и позволяет выявить нарушения функции легких, ограничивающие толерантность к нагрузке. Компьютерная спирометрия, проводимая перед КПНТ, регистрирует жизненную емкость легких (VC), объем форсированного выдоха за первую секунду (FEV1), максимальную вентиляцию легких (MMV) и другие параметры. Резерв дыхания при выполнении упражнений является индикатором того, насколько близко легочная вентиляция приближается к максимальной вентиляции легких и обычно вычисляется как 1 (пиковая вентиляция/MMV). B норме этот показатель у здоровых лиц превышает 0,2. Спортсмены с высоким сердечно-сосудистым потенциалом могут использовать значимо большую часть функционального резерва легких, и при выполнении нагрузки их легочная вентиляция прибли- 


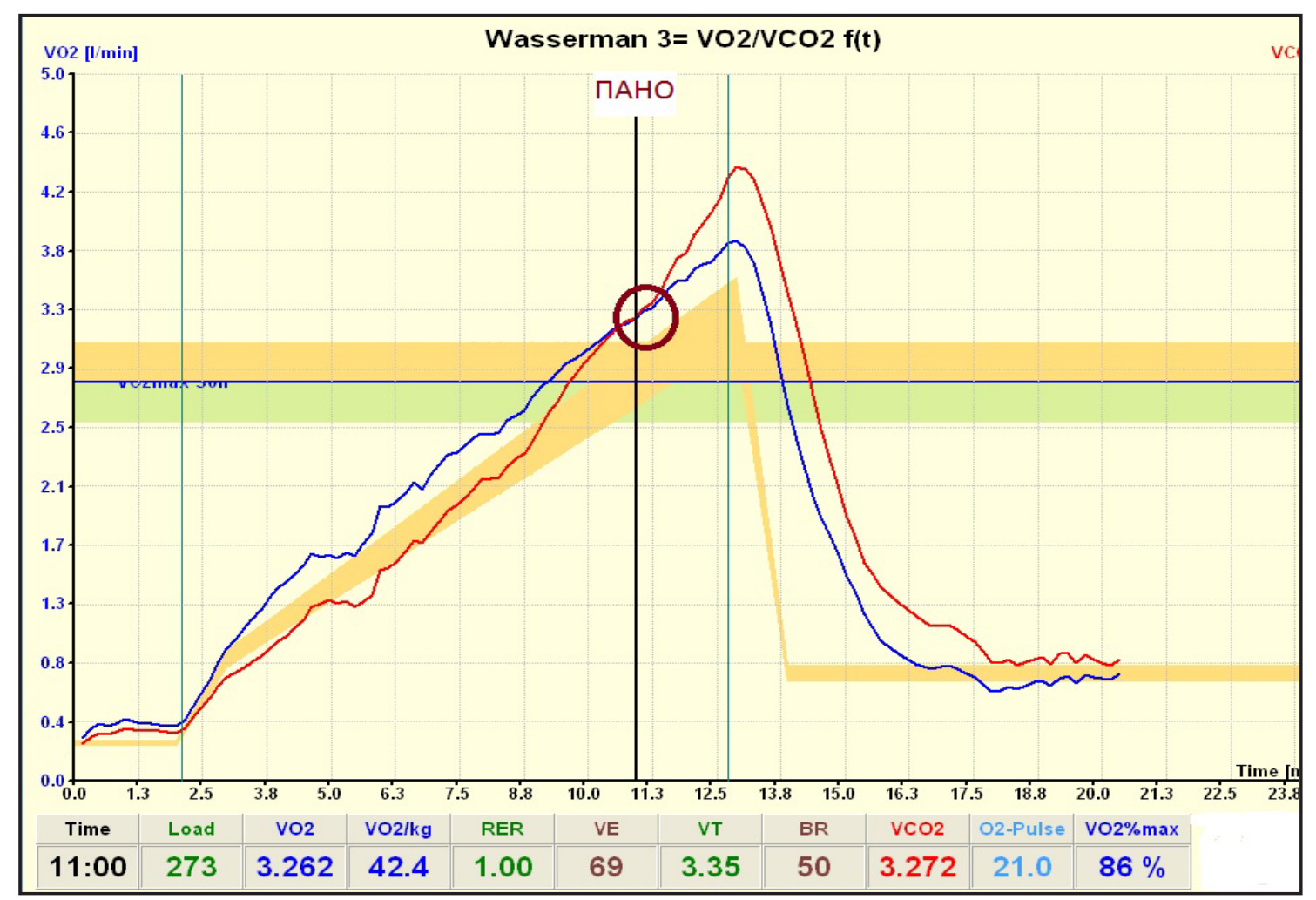

Рис. 1. Момент времени наступления порога анаэробного обмена (ПАНО) при пересечении кривых потребления О 2 и выделения $\mathrm{CO}_{2}$ во время нагрузочного тестирования (Wasserman K., 1973)

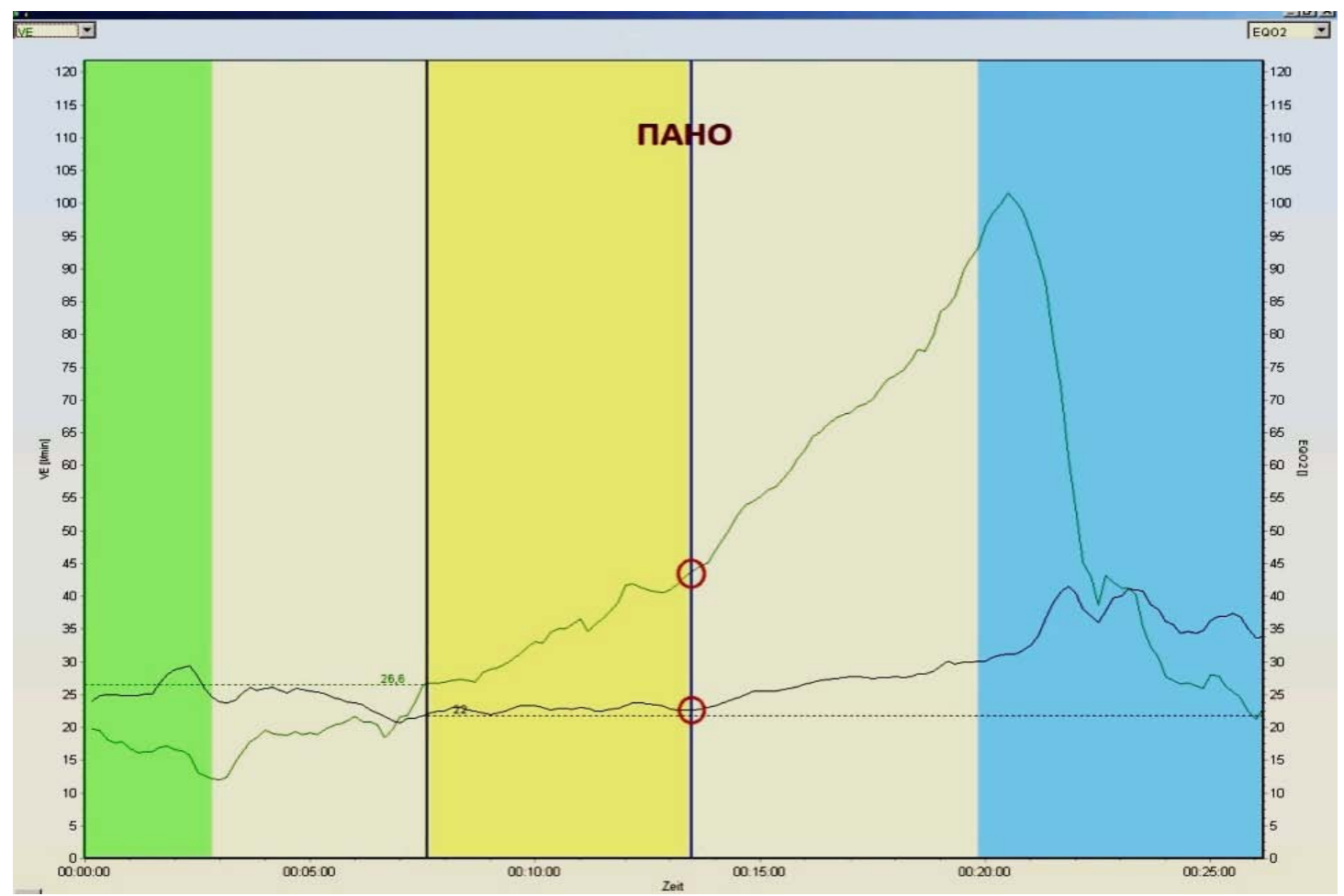

Рис. 2. Момент времени наступления порога анаэробного обмена (ПАНО) при наступлении системного увеличения дыхательного эквивалента для кислорода $\left(\mathrm{EQO}_{2}\right)$ и нелинейного увеличения легочной вентиляции (VE) на фоне нагрузочного тестирования (Wasserman K., 1973)

жается к максимальным значениям, что отражается в низком или нулевом резерве дыхания [1, 4].

8. Время нагрузки (t, мин) - максимально возможное для пациента на момент тестирования время выполнения нагрузки. Это наиболее информативный, прогностически значимый показатель функционального состояния тестируемого, который отражает уровень его фризической работоспособ- 
ности и адаптационных возможностей. Время нагрузки - интегральный показатель «успешности» выполнения любого функционального тестирования, не лимитированного временем [5].

9. Частота сердечных сокращений (ЧСС, уд/ мин) зависит от многих факторов, включая возраст, пол, положение тела, состояния перетренированности или недовосстановления. У спортсменов в покое ЧСС обычно ниже, чем у нетренированных [5].

10. Систолическое и диастолическое артериальное давление (АД). У здоровых людей АД при физической нагрузке увеличивается. Начальный период увеличения АД при ритмичной работе длится 1-2 мин, после чего оно устанавливается на стабильном уровне в зависимости от интенсивности работы. После прекращения работы АД резко падает и впервые 5-10 мин в восстановительном периоде может оказаться ниже исходного уровня с последующей его нормализацией [5].

Для оценки физической работоспособности спортсменов с помощью КПНТ используется протокол Bruce RA $[2,9]$. Данный протокол представляет собой ступенчатое увеличение нагрузки в ходе тестирования на тредмиле/велоэргометре и 5-минутный период восстановления.

При проведении КПНТ на аппарате Quark CPET фирмы COSMED (Италия) (рис. 3) у здоровых молодых мужчин для определения фризической работоспособности мы использовали модифицированный протокол Bruce. По данному протоколу начальная нагрузка соответствовала мощности 70 Вт. Затем каждые 2 мин увеличивали нагрузку на 50 Вт, которая к 12-й мин составляла 320 Вт (таблица). При достижении этой ступени мощность больше не по- вышали. По желанию обследуемого или решению врача вследствие усталости, одышки или других причин тестирование завершали при меньших значениях нагрузки с переходом в период восстановления

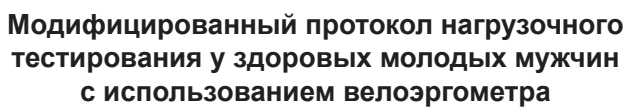

\begin{tabular}{|l|c|c|c|}
\hline \multicolumn{2}{|c|}{ Ступень } & Мощность, $\mathrm{Bm}$ & Продолжительность, мин \\
\hline Разминка & 1 & 20 & 20 сек \\
\hline & 2 & 70 & 2 \\
\cline { 2 - 4 } & 3 & 120 & 2 \\
\cline { 2 - 4 } & 4 & 170 & 2 \\
\cline { 2 - 4 } & 5 & 220 & 2 \\
\cline { 2 - 4 } & 6 & 270 & 2 \\
\cline { 2 - 4 } & 7 & 320 & $\geq 2$ \\
\hline \multirow{4}{*}{$\begin{array}{l}\text { Вогрузка } \\
\text { новлена- }\end{array}$} & 8 & 20 & 5 \\
\hline
\end{tabular}

Ниже представлены сводные протоколы КПНТ двух тестируемых мужчин. Исследуемый № 1 здоровый некурящий мужчина 23 лет, систематически занимающийся фризической культурой (рис. 4). Исследуемый № 2 - здоровый курящий мужчина 23 лет, эпизодически занимающийся фризической культурой (рис. 5). В ходе анализа протоколов КПНТ этих мужчин установили различия по многим параметрам.

В первом случае максимальное время выполнения нагрузки составило 11,42 мин, во втором случае - лишь 7,48 мин (в 1,5 раза ниже). Время наступления ПАНО у исследуемого № 1 было почти в 2 раза больше (8,24 мин), чем у 2-го тестируемого (4,55 мин). Максимальное потребление $\mathrm{O}_{2}$ у ис-

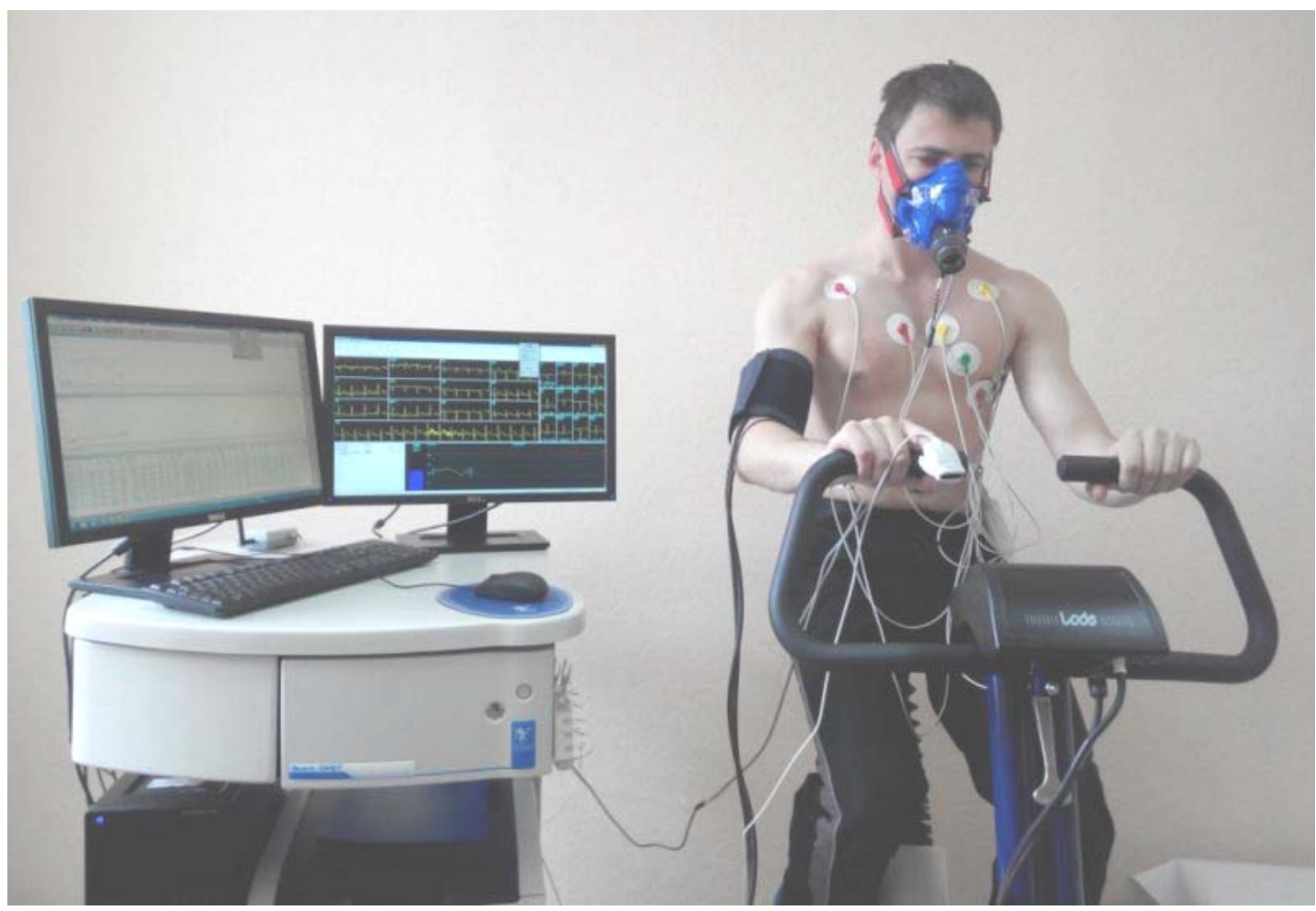

Рис. 3. Методика проведения КПНТ (собственный архив) 


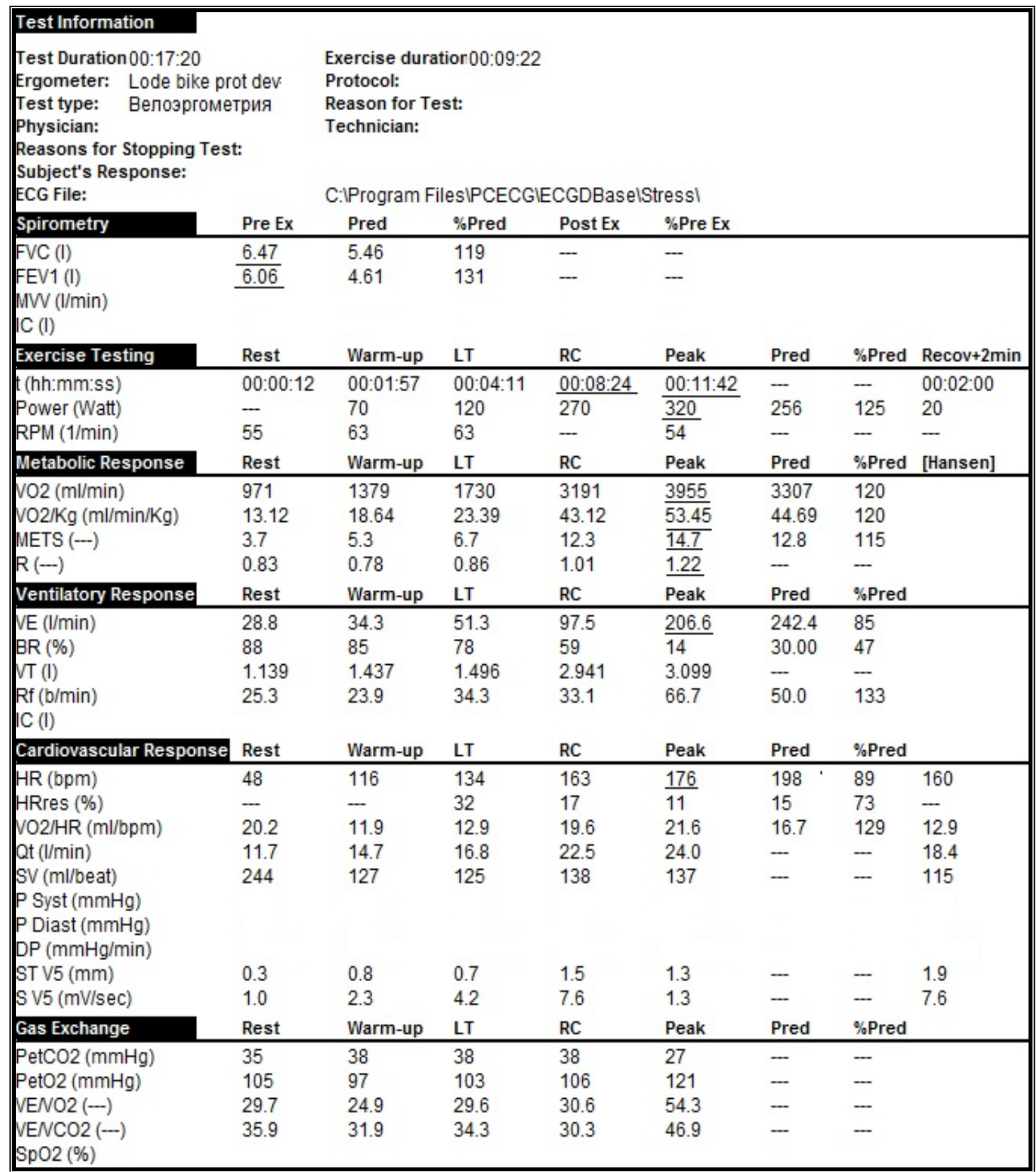

Рис. 4. Протокол КПНТ некурящего мужчины 23 лет (исследуемый № 1)

следуемого № 1 составило 53,45 мл/мин/кг против 35,50 мл/мин/кг у второго мужчины. Максимальная частота респираторного обмена (R Peak) в обоих случаях составила 1,2. Но максимальная аэробная

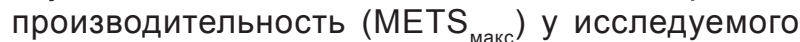
№ 1 достигала 14,7, а у исследуемого № $2-8,7$, максимальная мощность педалирования - 320 ВТ и 220 Вт соответственно. Максимальная минутная вентиляция (VE) в первом случае достигала 206,6 л/мин, у исследуемого № 2 была в 2,7 раза ниже (78 л/мин). Максимальное выделение $\mathrm{CO}_{2} \mathrm{y}$ некурящего спортсмена - 4642 мл/мин, во втором случае - 3554 мл/мин (показатель высчитывается по аппаратным данным).

Выводы. КПНТ является информативным методом оценки фризического здоровья человека. Предложенный модифицированный протокол Bruce для проведения КПНТ в максимальном нагрузочном тесте (с увеличением нагрузки на 50 Вт каждые 2 мин до отказа) может эффрективно использоваться для групповых обследований молодых здоровых мужчин. Планируется проведение такого исследования для оценки фризической работоспособности, оценки функционального состояния дыхательной и 


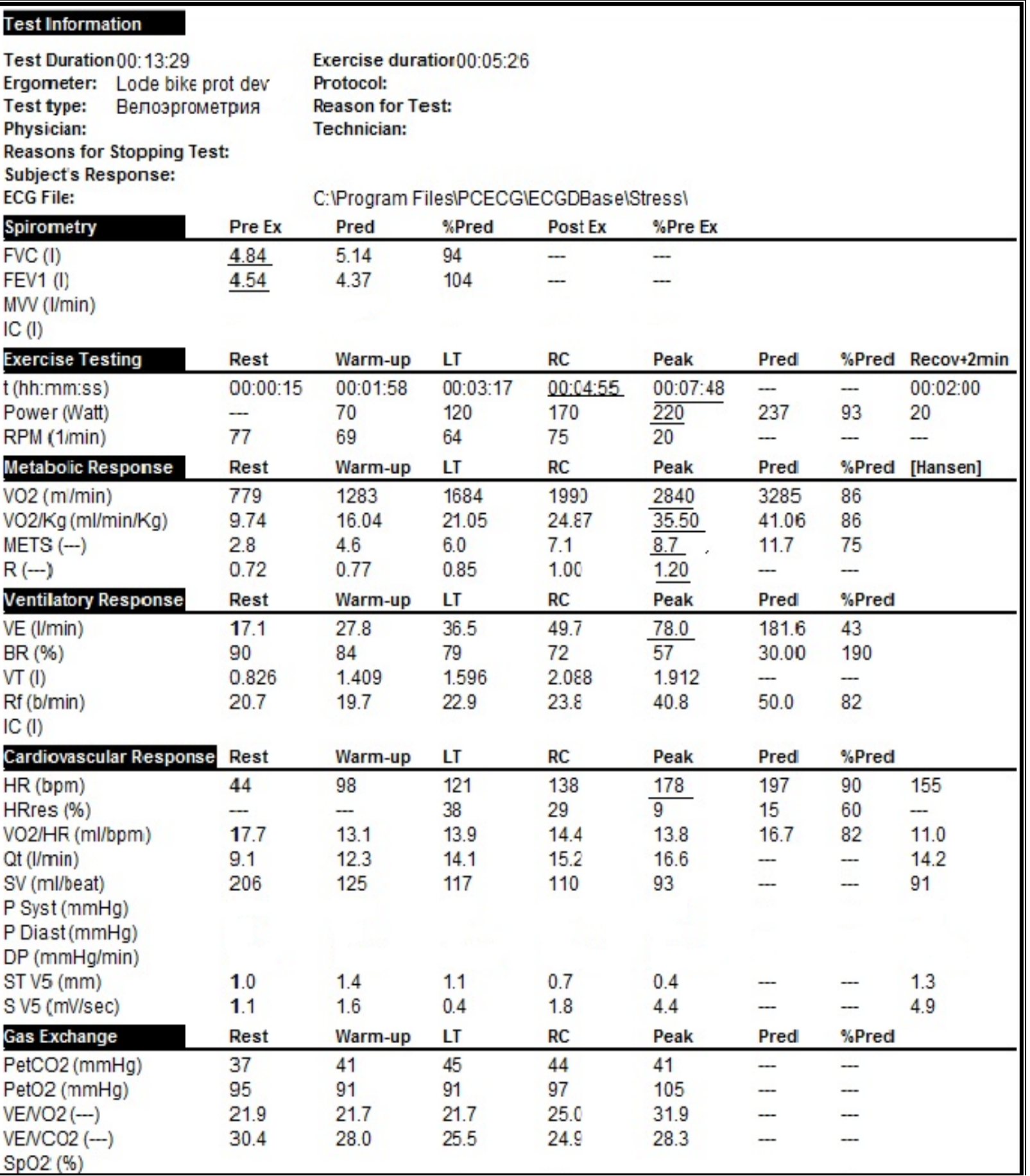

Рис. 5. Протокол КПНТ молодого курящего мужчины 23 лет (исследуемый № 2)

сердечно-сосудистой систем и выработки индивидуальных рекомендаций по проведению тренировок.

\section{ЛИТЕРАТУРА}

1. Кербиков, О.Б. Кардиопульмональное нагрузочное тестирование в клинической практике / О.Б. Кербиков, А.В. Аверьянов, Е.Н. Борская, Т.В. Крутова // Журнал клиническая практика. - 2012. - № 2. - С.58-70.

2. Balady, G.J. Clinician's Guide to Cardiopulmonary Exercise Testing in Adults: A Scientific Statement From the American Heart Association / G.J. Balady, R. Arena, K. Sietsema [et al.] // Circulation. - 2010. — Vol. 122. P.191-225.
3. Мустафина, М.X. Кардиореспираторный нагрузочный тест / М.X. Мустафина, А.В. Черняк // Атмосфрера. Пульмонология и аллергология. - 2013. - № 3. C.56-62.

4. Mezzania, A. Standards for the use of cardiopulmonary exercise testing for the functional evaluation of cardiac patients: a report from the Exercise Physiology Section of the European Association for Cardiovascular Prevention and Rehabilitation European tion / A. Mezzania, P. Agostonib, A. Cohen-Solald // Journal of Cardiovascular Prevention and Rehabilita. - 2009. — Vol. 16. - P.249-267.

5. Тавровская, Т.В. Велоэргометрия: практическое пособие для врачей / Т.В. Тавровская. - СПб., 2007. C.4-26, 68-71. 
6. Sherwood, L. The respiratory system / L. Sherwood // Fundamentals of Human Physiology. $-4^{\text {th }}$ ed. (Chapter 12). - 2011. - P.344-435.

7. Wasserman, K. Coupling of external to cellular respiration during exercise: the wisdom of the body revisited / K. Wasserman // Am. J. Physiol. — 1994. — Vol. 266(4/1). P.519-539.

8. American College of Sports Medicine. ACSM's Guidelines for Exercise Testing and Prescription. - $8^{\text {th }}$ ed. - Baltimore: Lippincott Williams \& Wilkins, 2010. - P.286-299.

9. Forman, $D$. Cardiopulmonary exercise testing: Relevant but underused / D. Forman, J. Myers, C.J. Lavie [et al.] // Postgrad. Med. - 2010. - Vol. 122(6). - P.68-86.

\section{REFERENCES}

1. Kerbikov, O.B. Kardiopul'monal'noe nagruzochnoe testirovanie $v$ klinicheskoi praktike [Cardiopulmonary exercise testing in clinical practice] / O.B. Kerbikov, A.V. Aver'yanov, E.N. Borskaya, T.V. Krutova // Zhurnal klinicheskaya praktika [Zhurnal clinical practice]. 2012. — № 2. - S.58-70.

2. Balady, G.J. Clinician's Guide to Cardiopulmonary Exercise Testing in Adults: A Scientific Statement From the American Heart Association / G.J. Balady, R. Arena, K. Sietsema [et al.] // Circulation. — 2010. — Vol. 122. — P.191-225.

3. Mustafina, M.H. Kardiorespiratornyi nagruzochnyi test [Cardiopulmonary exercise testing] / M.H. Mustafina,
A.V. Chernyak // Atmosfera. Pul'monologiya i allergologiya [Zhurnal Atmosphere. Pulmonology and allergology]. 2013. - № 3. - S.56-62.

4. Mezzania, A. Standards for the use of cardiopulmonary exercise testing for the functional evaluation of cardiac patients: a report from the Exercise Physiology Section of the European Association for Cardiovascular Prevention and Rehabilitation European tion / A. Mezzania, P. Agostonib, A. Cohen-Solald // Journal of Cardiovascular Prevention and Rehabilita. - 2009. - Vol. 16. - P.249-267.

5. Tavrovskaya, T.V. Veloergometriya: prakticheskoe posobie dlya vrachei [Veloergometry. A practical guide for physicians] / T.V. Tavrovskaya. — SPb., 2007. — S.4-26, 68-71.

6. Sherwood, L. The respiratory system / L. Sherwood // Fundamentals of Human Physiology. $-4^{\text {th }}$ ed. (Chapter 12). - 2011. - P.344-435.

7. Wasserman, K. Coupling of external to cellular respiration during exercise: the wisdom of the body revisited / K. Wasserman // Am. J. Physiol. — 1994. — Vol. 266(4/1). P. 519 - 539.

8. American College of Sports Medicine. ACSM's Guidelines for Exercise Testing and Prescription. $-8^{\text {th }}$ ed. - Baltimore: Lippincott Williams \& Wilkins, 2010. - P.286-299.

9. Forman, D. Cardiopulmonary exercise testing: Relevant but underused / D. Forman, J. Myers, C.J. Lavie [et al.] // Postgrad. Med. — 2010. — Vol. 122(6). — P.68-86.

Принята 11.08.2014

(ㄷ Г.Р. Рувинская, Ю.В. Фазылова, 2015

УДК 616.314.18-002-085

\section{ЭФФЕКТИВНОСТЬ ПРОТИВОМИКРОБНЫХ ПРЕПАРАТОВ В ЛЕЧЕНИИ ОБРАТИМЫХ ПУЛЬПИТОВ БИОЛОГИЧЕСКИМ МЕТОДОМ}

ГУЗЕЛЬ РЕНАДОВНА РУВИНСКАЯ, канд. мед. наук, доцент кафедры терапевтической детской стоматологии и ортодонтии ГБОУ ДПО «Казанская государственная медицинская академия» Минздрава России, Казань, Россия, тел. 8-917-278-98-34, e-mail: guzelruv@mail.ru

ЮЛИЯ ВИЛЬДАНОВНА ФАЗЫЛОВА, канд. мед. наук, доцент кафедры терапевтической стоматологии ГБОУ ВПО «Казанский государственный медицинский университет» Минздрава России, Казань, Россия, тел. 8-903-341-63-82, e-mail: fazylovayulia@mail.ru

Реферат. Цель исследования - провести клиническую оценку эффективности комбинированных препаратов, содержащих кортикостероид местного действия, при лечении обратимых фрорм пульпита биологическим методом. Материал и методы. Проведен анализ лечения 17 пациентов с острым очаговым серозным пульпитом, гиперемией пульпы по результатам электровозбудимости пульпы, рентгенологической картине периапикальных тканей, оценке болевого синдрома с помощью числовой ранговой шкалы. Результаты и их обсуждение. Установлено, что при применении комбинированного средства, содержащего антибиотик и кортикостероид местного действия, развивается выраженный обезболивающий эффект, возникающий в $22 \%$ случаев в первые часы после наложения препарата, в 66,7\% - в течение одних суток. Обосновано применение пасты, содержащей антибиотик и кортикостероид местного действия, для сохранения жизнеспособности пульпы, за счет выраженного противовоспалительного и антимикробного действия, наступающего на 2-3-и сут от начала лечения и сохраняющегося в течение всего реабилитационного периода у $77,8 \%$ пациентов.

Ключевые слова: пульпит обратимый, биологический метод лечения.

\section{EFFICIENCY OF ANTIMICROBIC TREATEMENT IN TREATMENT OF REVERSIBLE PULPITISES BY THE BIOLOGICAL METHOD}

GUZEL R. RUVINSKAYA, Ph.D., associate professor of Department of therapy pediatric and orthodontic dentistry of SBEl APE «Kazan State Medical Academy», Russia, Kazan, tel. 8-917-278-98-34 e-mail: guzelruv@mail.ru JULIA V. FAZYLOVA, Ph.D., associate professor of Department of therapy, pediatric and orthodontic dentistry of SBEI APE «Kazan State Medical University», Russia, Kazan, tel. 8-903-341-63-82, e-mail: fazylovayulia@mail.ru

Abstract. The purpose of the study was to conduct a clinical evaluation of the effectiveness of combination products containing topical corticosteroids for the treatment of reversible forms of pulpitis by biological method. Material and methods. We analyzed the treatment of 17 patients with acute focal serous pulpitis, hyperemia of the pulp by the results of the pulp electroexcitability, X-ray pattern of the periapical tissues, assessment of pain using a numeric rank scale. Results and discussion. We demonstrated that the application of combined srugs containing an antibiotic and topical 
corticosteroid, had a pronounced analgesic effect, which occurs in $22 \%$ of cases in the first hours after the application, and in 66,7\% - during the 1st day. Conclusion. The application of a paste with antibiotic and topical corticosteroid for vitality of the pulp was indicated due to the expressed anti-inflammatory and antimicrobial action, coming at $2-3$ days of starting treatment and continued throughout the rehabilitation period in $77,8 \%$ of patients.

Key words: reversible pulpitis, biological treatment.

$\mathrm{B}^{\mathrm{n}}$ ведение. Современная тактика лечения пульпита предусматривает полное удаление воспаленной пульпы с последующей обтурацией корневых каналов с использованием силеров и гуттаперчи. Выбор метода обусловлен рядом факторов, в первую очередь, сроками обращения пациентов за помощью, как правило, на этапе необратимых изменений, с поздней и недостаточной диагностикой воспалительных процессов в пульпе при лечении неосложненных форм кариеса, а также возможно ограниченными показаниями и строгим в исполнении перечнем этапов и манипуляций консервативного метода лечения, что ограничивает его применение в повседневной тактике врачастоматолога. Отдаленные результаты наблюдения за депульпированными зубами свидетельствуют о появлении таких «нежелательных» явлений, как хрупкость, потеря больших объемов твердых тканей, что требует обязательного ортопедического лечения с применением вкладки и коронки, и, наконец, о развитии осложнений в виде апикального периодонтита в результате некачественной обтурации корневых каналов после лечения пульпита [1-4].

В связи с этим представляется актуальным более широкое внедрение в ежедневную практику врача-стоматолога-терапевта консервативных методов лечения пульпита, направленных на полное или частичное сохранение жизнеспособной пульпы.

Консервативный метод лечения включает в себя две методики - полное сохранение жизнеспособности пульпы (биологический метод) и метод витальной ампутации, предусматривающий сохранение корневой пульпы, что особенно актуально в многокорневых зубах [1, 3, 4].

В основе биологического метода лечения пульпита лежит воздействие лекарственных веществ на микроорганизмы - причину воспалительного процесса, и на ткань пульпы с целью восстановления ее морфологического и функционального состояния.

Сохранение живой полноценной пульпы очень важно для зуба и организма в целом, что обусловлено ее основными функциями - защитной, трофической и пластической. В случае воспаления и гибели пульпы возникают проблемы хронической стоматогенной инфекции и сенсибилизации организма, а в последующем и развитие осложнений, нередко ведущих к потере зуба $[1,3,4,7]$.

Предпосылками для разработки биологического метода лечения пульпитов явились накопленные за последние три десятилетия данные по биологии и патологии пульпы, изменившие существовавший ранее взгляд на воспаленную пульпу как на, безусловно, обреченный орган.
Хорошим фундаментом для развития данного направления являются и фармакологические разработки современной стоматологической промышленности, выпускающей комбинированные препараты, воздействующие на основные звенья воспалительного процесса в пульпе зуба [2, 7].

Традиционно для биологического метода лечения пульпита применяют лечебные пасты для прямого и непрямого покрытия пульпы на основе гидроксида кальция. Применение препаратов этой группы обусловлено широким спектром их патогенетического воздействия на воспаленную пульпу - антимикробным, противовоспалительным и одонтотропным [4].

Широко применяются лечебные препараты, содержащие комбинации нескольких лекарственных средств, чаще всего антибиотики и глюкокортикостероиды. Наиболее популярны из них пасты, содержащие в своем составе ацетат дексаметазона и антибактериальные препараты, такие как сульфат фрамицетина и полимиксин В. Комплексное сочетание дексаметазона, обладающего активным противовоспалительным и противоотечным действием, и двух антибиотиков широкого спектра действия в малых дозах обеспечивает выраженный терапевтический эффект препарата и определяет спектр его применения, в том числе при лечении симптоматического пульпита [1-4, 6, 7]. При этом следует добавить, что кортикостероиды, водящие в состав комбинированных средств, применяемых для лечения симптоматических пульпитов, обладая пролонгированным действием, могут оказывать влияние на организм в целом, кумулируясь в организме, что может иметь неблагоприятные последствия, особенно у пациентов с отягощенной соматической патологией.

Появление на отечественном стоматологическом рынке препарата, содержащего кортикостероиды местного действия, определило широкие возможности для терапии осложнений кариеса, в том числе биологическим методом [2, 7]. Основу препарата составили антибиотик широкого спектра действия с бактериостатическим эфрфектом - демеклоциклин (Demeclocycline hydrochloride), эффрективный по отношению к микроорганизмам, характерным при воспалительных процессах в тканях пульпы и периодонта, и фрторированный глюкокортикостероид местного действия (ФКМД) - триамцинолон (Triamcinolone acetonide), обладающий выраженными противоаллергическими, деконгестивными и противовоспалительными эффектами.

В доступной отечественной литературе оказалось недостаточно сведений о результатах применения препаратов, содержащих ФКМД, для лечения и профилактики воспалительных изменений в пульпе 
зуба, в том числе результатов сравнительной оценки эффрективности данного препарата с аналогичными средствами. На основании чего была сфрормулирована цель нашего исследования - провести клиническую оценку эфффективности комбинированных препаратов, содержащих антибиотик и ФКМД, при лечении обратимых форм пульпита биологическим методом.

Материал и методы. В исследовании принимали участие 17 пациентов в возрасте от 18 до 35 лет с диагнозами «гиперемия пульпы», «острый очаговый серозный пульпит», т.е. основными формами обратимого пульпита. Выборка пациентов для проведения исследования проводилась с учетом основных показаний к биологическому методу лечения пульпита, а именно: отсутствие длительного болевого синдрома (более 2 мин) под действием термических и химических раздражителей на фоне клинической картины гиперемии пульпы или начального пульпита. Отсутствие реакции со стороны периапикальных тканей - безболезненность при накусывании на зуб, подтвержденное данными рентгенологического исследования. Возраст пациента не старше 35-40 лет. Обязательным условием для отбора клинического материала явилась хорошая гигиена полости рта и низкая интенсивность кариеса, а также отсутствие сопутствующей патологии слизистой оболочки ротовой полости и тканей пародонта и тяжелой органной патологии внутренних органов, таких как сахарный диабет, заболевания щитовидной железы, сердечнососудистая патология и т.д.

Всем пациентам в качестве обязательного метода обследования проводилось определение электровозбудимости пульпы (ЭОД). Показатели ЭОД до 20 мкА явились критерием отбора пациентов для исследования.

Одним из основных симптомов воспаления является боль. Боль при пульпите - важный дифференциально-диагностический признак, позволяющий оценивать эффеективность проводимой терапии на разных этапах, в том числе на этапе реабилитации. В нашем исследовании оценка болевого синдрома как критерия эффективности на разных этапах исследования - до лечения, после наложения препарата и на этапе реабилитации проводилась с использованием числовой ранговой шкалы (ЧРШ) [5].

Данный критерий оценки достаточно прост, так как шкала состоит из ряда чисел от 0 до 10. Болевые ощущения пациентам предлагают оценить цифрами в диапазоне от 0 (нет боли) до 10 (максимально возможная боль). Сравнивая оценки болевых ощущений по этой шкале на разных этапах лечения можно судить о его эффективности. В нашем исследовании ЧРШ применялась у всех пациентов на этапе диагностики, непосредственно после нанесения лечебной пасты и перед наложением постоянной пломбы.

Лечение с применением пасты, содержащей ФКМД, проводилось в два этапа. В первое посещение для сохранения жизнеспособности пульпы при начальных (обратимых) формах пульпита пасту накладывали на дно кариозной полости по- сле предварительной подготовки зуба со строгим соблюдением всех правил асептики и антисептики. Для этого сначала проводились ЭОД, температурная проба, оценка боли по ЧРШ, затем после обезболивания причинного зуба, инструментальной обработки и тщательной медикаментозной обработки кариозной полости слабым раствором антисептика (0,05\% раствор хлоргексидина биглюконата, подогретый до температуры тела) пасту накладывали непрямым способом тонким слоем на дентин, изолирующий полость зуба. Далее с помощью стерильного ватного тампона и временной пломбы изолировали лечебную прокладку от полости рта.

Всем пациентам были даны рекомендации, обеспечивающие достижение максимального успеха проводимого лечения, а также исследуемые предупреждались о возможности сохранения и даже усиления болевого синдрома и появления новых симптомов, говорящих о прогрессировании процесса. В этих случаях пациенту предлагалось срочно явиться на прием для проведения хирургического (экстирпационного) метода лечения пульпита.

При отсутствии боли и других признаков прогрессирования патологического процесса пациент приглашался на повторный прием через 7-10 дней.

Во второе посещение (через 7-10 дней) оценивали все контрольные критерии и при отсутствии отрицательной динамики проводили реставрацию коронки зуба с применением фотокомпозита с четким соблюдением принципов окклюзионного соотношения.

В процессе исследования с использованием препарата, содержащего ФКМД, всего было вылечено 11 зубов с острым очаговым пульпитом и гиперемией пульпы (обратимым пульпитом).

В процессе изучения эффективности пасты, содержащей антибиотик широкого спектра действия и ФКМД, для сохранения жизнеспособности пульпы при обратимых пульпитах нами была проведена сравнительная оценка этого препарата с аналогичными по свойствам средствами, содержащими в составе помимо антибиотика кортикостероид общего действия, используя при этом те же критерии оценки - показатели электроодонтодиагностики, ЧРШ и рентгенографии. С этой целью было вылечено 9 зубов с диагнозом «острый очаговый пульпит». Контрольные осмотры в процессе реабилитации с целью оценки результатов лечения и показателей жизнеспособности пульпы проводили через 1, 3, 6 и 12 мес наблюдения.

Результаты и их обсуждение. Применение пасты, содержащей ФКСМД, у пациентов с обратимым пульпитом показало, что данный комбинированный препарат обладает выраженным противовоспалительным и антимикробным действием, а также обеспечивает быстрый обезболивающий эффрект, в большинстве случаев наступающий сразу после нанесения пасты.

Так, при лечении обратимого пульпита с применением пасты, содержащей ФКМД, уменьшение болевого синдрома в 2,5 раза по ЧРШ [средний 
показатель составил $(3,4 \pm 0,21)$ балла, что соответствовало значению «слабая боль»] наблюдалось у $6(66,7 \%)$ пациентов на 1-е сут, на 3-и сут отсутствие боли отметили все пациенты. При этом 2 (22\%) пациента отметили значительное облегчение состояния практически сразу после наложения изучаемой пасты. Противовоспалительный эффеект отмечался во всех случаях на 2-е сут.

Результаты осмотра пациентов через месяц показали положительную динамику процесса в виде отсутствия жалоб, реакции со стороны периапикальных тканей, кратковременную реакцию (менее 1 мин) на термические раздражители, а также снижение числовых значений показателей ЭОД в среднем в 1,5 раза - до $(11,8 \pm 1,21)$ мкА. На отдаленных сроках наблюдения $(3,6,12$ мес) в данной группе пациентов сохранялась стабильно положительная динамика изучаемых показателей, и только у 2 (22,2\%) пациентов на сроке 12 мес отмечены признаки хронического воспаления - снижение электровозбудимости пульпы до 40-45 мкА, наличие приступов самопроизвольной боли в анамнезе.

Результаты сравнительной оценки эффрективности лечебной пасты, содержащей антибиотики и ФКМД, с аналогичной пастой, содержащей антибиотик и кортикостероид общего действия, при лечении обратимых форм пульпита методом полного сохранения жизнеспособности пульпы не выявили достоверных различий по основным параметрам, таким как показатели ЭОД, рентгенологическая картина периапикальных тканей в отдаленные сроки наблюдения, что доказывает эффективность пасты с ФКМД в группе комбинированных препаратов, применяемых для лечения и профилактики пульпита.

Достоверно более высокими по отношению к группе сравнения стали показатели, характеризующие антиангинальный эффект пасты, содержащей ФКМД. Так, при оценке сохранения болевого синдрома после наложения пасты с ФКМД боль исчезала полностью или оценивалась пациентами как «слабая или чувство дискомфорта» в 72\% случаев, тогда как в группе сравнения - только в $43 \%$ случаев.

Таким образом, паста, содержащая ФКМД, не только обеспечивает мощное противовоспалительное действие, непосредственно воздействуя на этиологическую причину воспаления (бактериальную флору) и на патологические ответные реакции организма (болевой синдром). Подобный положительный момент оказывает неоценимую помощь врачу также в тех случаях, когда неэффрективны другие обезболивающие средства, такие как местные анестетики.

В то же время отсутствие побочных эффректов в виде отрицательного влияния на организм в целом, стойкий положительный результат лечения на отдаленных сроках наблюдения, обусловленное содержанием в средстве фрторированного кортикостероида местного действия, несомненно, повышает интерес к нему со стороны практикующих врачейстоматологов всех специальностей.
Вывод. При лечении пульпитов постоянных зубов биологическим методом, для снятия острого болевого синдрома при обратимых пульпитах следует применять современные комбинированные препараты, содержащие антибиотики и фрторированые кортикостероиды местного действия, ввиду их высокой эфффективности и безопасности, что особенно актуально у пациентов с отягощенным соматическим статусом.

\section{ЛИТЕРАТУРА}

1. Боровский, Е.В. Ошибки эндодонтического лечения зубов / Е.В. Боровский // Клиническая эндодонтия. М., 2003. - C.32-35.

2. Масюкова, Э.А. Применение пасты «ЛЕДЕРМИКС» при лечении больных с осложненными формами кариеса / Э.А. Масюкова // Вестник КазНМУ. — 2013. — № 3(1). C.159-160.

3. Петрикас, А.Ж. Пульпэктомия / А.Ж. Петрикас. - М.: АльфаПресс, 2006. - 300 с.

4. Эндодонтология / под ред. Г. Бердженхольц; пер. с англ. под науч. ред. С.А. Кутяева. - М.: Таркомм, 2013. $-408 \mathrm{c}$.

5. Bonica, J.J. The management of pain // J.J. Bonica. 2nd ed. - Philadelphia, PA: Lea\&Febiger, 1990. P.28-94.

6. Briseno Marroquin, B. Die antibakterielle Wirkung von Ledermix als medikamentöse Wurzelkanaleinlage - eine InvitroVersuch sreihe / B. Briseno Marroquin, E. Viola, A.B. Christoffers, B. Willershausen // Dtsch. Zahnarztl. Z. - 2004. - Vol. 59. - P.650-654.

7. Lewis, B.B. Formaldehyde in dentestry: a rewiew of mutogenie and carinogenic potential / B.B. Lewis, S.B. Chestner / J. Am. Dent. Assoc. - 1981. Vol. 103. - P.429-434.

\section{REFERENCES}

1. Borovskii, E.V. Oshibki endodonticheskogo lecheniya zubov [Errors endodontic treatment of teeth] / E.V. Borovskii // Klinicheskaya endodontiya [Clinical Endodontics]. - M., 2003. - S.32-35.

2. Masyukova, E.A. Primenenie pasty «LEDERMIKS» pri lechenii bol'nyh s oslozhnennymi formami kariesa [Use of LEDERMIKS paste at treatment of patients with the complicated caries forms] / E.A. Masyukova // Vestnik KazNMU [The Messenger of KAZNMU]. - 2013. № 3(1). - S.159-160.

3. Petrikas, A.Zh. Pul'pektomiya [Pulpektomiya] / A.Zh. Petrikas. - M.: Al'faPress, 2006. - $300 \mathrm{~s}$.

4. Endodontologiya / pod red. G. Berdzhenhol'c [Endodontologiya. Under edition Gunnar Berdzhencholz]; per. $s$ angl. pod nauch. red. S.A. Kutyaeva. - M.: Tarkomm, 2013. - $408 \mathrm{~s}$.

5. Bonica, J.J. The management of pain // J.J. Bonica. 2nd ed. - Philadelphia, PA: Lea\&Febiger, 1990. P.28-94.

6. Briseno Marroquin, B. Die antibakterielle Wirkung von Ledermix als medikamentöse Wurzelkanaleinlage - eine InvitroVersuch sreihe / B. Briseno Marroquin, E. Viola, A.B. Christoffers, B. Willershausen // Dtsch. Zahnarztl. Z. - 2004. - Vol. 59. - P.650-654.

7. Lewis, B.B. Formaldehyde in dentestry: a rewiew of mutogenie and carinogenic potential / B.B. Lewis, S.B. Chestner / J. Am. Dent. Assoc. - 1981. Vol. 103. - P.429-434.

Принята 09.10.2014 


\title{
ДИАГНОСТИЧЕСКИЕ ВОЗМОЖНОСТИ ТЕСТА АКТИВАЦИИ БАЗОФИЛОВ В ВЫЯВЛЕНИИ СЕНСИБИЛИЗАЦИИ К ЯДАМ ПЕРЕПОНЧАТОКРЫЛЫХ НАСЕКОМЫХ
}

ЛЕЙСЕН ФАРИТОВНА САФИНА, врач-алЛерголог ФБУН «Казанский научно-исследовательский институт Эпидемиологии и микробиологии» Роспотребнадзора, Казань, Россия, тел. 8-843-236-67-21, e-mail: safina-doc@mail.ru РУСТЭМ САЛАХОВИЧ ФАССАХОВ, докт. мед. наук, профессор, главный внештатный аллерголог ПФО и МЗ РТ, директор ФБУН «Казанский научно-исследовательский институт эпидемиологии и микробиологии» Роспотребнадзора, Казань, Росия, тел. 8-843-236-67-21, e-mail: farrus@mail.ru

ЕЛЕНА ВАЛЕНТИНОВНА АГАФОНОВА, канд. мед. наук, ассистент кафедры пропедевтики детских болезней и факультетской педиатрии с курсом детских болезней ГБОУ ВПО «Казанский государственный медицинский университет» Минздрава России, зав. лабораторией ФБУН «Казанский научно-исследовательский институт эпидемиологии и микробиологии» Роспотребнадзора, Казань, Россия, тел. 8-843-236-67-21, e-mail: agafono@mail.ru

Реферат. Цель работы - оценить клинико-диагностическую значимость методов лабораторной диагностики в выявлении сенсибилизации к ядам перепончатокрылых насекомых. Материал и методы. Обследованы 102 пациента с системными аллергическими реакциями на ужаление перепончатокрылых насекомых, которые проходили стационарное лечение в аллергологическом отделении ГАУЗ ГКБ № 7 г. Казани. Сформированы две группы больных с системными аллергическими реакциями и анафилактическим шоком. В структуре групп выделены подгруппы с положительным анамнезом на ужаление пчелы, осы и группа с анамнезом на ужалением неизвестного насекомого. Контрольную группу составили 30 человек. Всем пациентам выполнено определение специфических IgE-AT (ИФА), уровень активации базофилов к аллергенам пчелы, осы, шершня. Заключение. Выявлена высокая чувствительность и специфичность теста активации базофилов по сравнению с ИФАдиагностикой в выявлении сенсибилизации к ядам перепончатокрылых насекомых.

Ключевые слова: системные аллергические реакции, ужаление перепончатокрылыми насекомыми, специфические IgE, тест активации базофилов.

\section{POSSIBILITIES OF BASOPHIL ACTIVATION TEST IN DIAGNOSTIC OF HYMENOPTERA SENSITIZATION}

\author{
LEYSEN F. SAFINA, allergologist of Kazan Scientific and Research institute of epidemiology and microbiology, \\ Kazan, Russia, tel. 8-843-236-67-21, e-mail: safina-doc@mail.ru \\ RUSTEM S. FASSAKHOV, M.D., Professor, Principal allergologist-immunologist at Ministry of Healthcare and Social \\ Development of Tatarstan Republic, Head of Kazan Scientific and Research institute of epidemiology and microbiology, \\ Kazan, Russia, tel. 8-843-236-67-21, e-mail: farrus@mail.ru \\ ELENA V. AGAFONOVA, Ph.D., assistant of Professor of Department of pediatry chair of SBEI HPE «Kazan State \\ Medical University", Head of the clinical laboratory of Kazan Scientific and Research institute of epidemiology \\ and vicrobiology, Kazan, Russia, tel. 8-843-236-67-21, e-mail: agafono@mail.ru
}

\begin{abstract}
Aim. To compare clinical and diagnostic significance of laboratory methods for Hymenoptera sensitization detection. Material and methods. 102 patients with systemic allergic reactions to Hymenoptera sting were involved. All of them were treated in allergy department of Kazan Clinical Hospital №7. There were 2 groups of patients formed, both of them with systemic allergic reactions and anaphylactic shock. The structure of groups shows 2 subgroups: first - with positive anamnesis to wasp and bee sting, second - with anamnesis to unknown insect sting. The controlled group was forms of 30 persons. Measurement of specific IgE levels (ELISA test) and Basophil activation test for bees, wasps and hornets' allergens were performed for these patients. Conclusion. Basophil activation test was more sensitive and specific compared to ELISA test in diagnostic of Hymenoptera sensitization.
\end{abstract}

Key word: systemic allergic reactions, hymenoptera sting, ELISA test, Basophil activation test.

$\mathrm{B}$ ведение. Аллергические реакции на ужаление перепончатокрылыми насекомыми по внезапности возникновения, остроте развития и тяжести состояния больного являются одной из актуальных проблем практической аллергологии. В Европе частота встречаемости тяжелых системных аллергических реакций (САР) на яд жалящих насекомых составляет 0,3-8,9\% в популяции, в США - 0,5-3,3\%, в России по различным регионам встречается у $0,1-0,4 \%$ населения [1-5].

Одной из важных задач современной диагностики инсектной аллергии является выявление виновного аллергена с последующим проведением специфической иммунотерапии. При САР на ужаление перепончатокрылых насекомых специфические IgE-AT (slgE-AT) обнаруживают в 70-80\% случаев, а при местных реакциях - в $52 \%$. При этом у $10-20 \%$ пациентов с клиникой САР на ужаление насекомыми slgE-AT к яду насекомых выявить не удается [6, 7]. Достаточно часто у пациентов выявляются slgE-AT одновременно к разным насекомым (перекрестные реакции или наличие двойной сенсибилизации при повторных ужалениях разных насекомых). Помимо этого, достаточно часто врачи не могут идентифицировать жалящее насекомое, в связи с чем возникает необходимость поиска новых 
подходов в диагностике инсектной аллергии. Одним из перспективных методов является тест активации базофилов (ТАБ). Сенсибилизированные к яду перепончатокрылых насекомых клетки активируют специфическим аллергеном, об активации судят по экспрессии $\mathrm{CD}_{63}$-антигенов на поверхности базофилов, определяемых методом проточной цитометрии. Определение экспрессии антигена активации $\mathrm{CD}_{63}$ на базофилах дает возможность выявить 1-й тип реакций гиперчувствительности к аллергену, даже если в периферической крови не присутствуют slgEAT [8]. В ряде работ исследователей тест показал высокую чувствительность и специфичность [9-12]. По мнению авторов, внедрение ТАБ в рутинную практику врача открывает новые возможности для первичной диагностики инсектной аллергии [13].

Целью работы является оценка клиникодиагностической значимости методов лабораторной диагностики в выявлении сенсибилизации к ядам перепончатокрылых насекомых.

Материал и методы. Обследованы 102 пациента, из них 43 женщины (42\%) и 59 мужчин (57\%) с CAP на ужаление перепончатокрылыми насекомыми; пациенты проходили стационарное лечение в аллергологическом отделении ГАУЗ ГКБ № 7 г. Казани. В соответствии с задачами исследования были сорормированы 2 группы больных с САР и анафилактическим шоком (АШ). В структуре групп как с САР, так и с АШ были сформированы группы с положительным анамнезом на ужаление пчелы, осы и группа с анамнезом на ужаление неизвестного насекомого. В качестве контроля обследована группа здоровых добровольцев $(n-30)$, сопоставимая по возрасту и полу.

Программа лабораторного обследования пациентов включала:

1) определение уровня slgE-AT к ядам пчелы, осы, шершня [диагностические набо- ры для ИФА «АлкорБио» (Санкт-Петербург), «Radim»(Италия)];

2) определение уровня активации базофилов с использованием аллергенов яда пчел, ос, шершня (BUEHLMANN, Flou-CAST-Allergens) c помощью диагностического набора BASOTEST тм (Glicotope Biotechnology, Germany). Оценку активации базофилов по повышению экспрессии $\mathrm{CD}_{63}$ проводили на проточном цитометре «FacsCalibur» (BD,USA).

Полученные данные были обработаны с использованием пакета программ SPSS v.13.0 и Statistica 7.0.

Результаты и их обсуждение. Из 102 пациентов, включенных в исследование, у 50 пациентов был диагностирован АШ (49\%), у 52 - САР, из них в 12 случаях - САР 1-й степени (11\%), в 23 случаях - САР 2-й степени (22\%), САР 3-й степени в 17 случаях (16\%).

В соответствии с дизайном исследования была проведена оценка значимости тестов в выявлении сенсибилизации к ядам перепончатокрылых насекомых. К важнейшим характеристикам лабораторных тестов относится их специфичность и чувствительность. Чувствительность мы определили как процент положительных результатов пациентов в соответствии с их анамнезом, специфичность - как процент отрицательных тестов в группе контроля [10].

Чувствительность определения slgE-AT к яду пчелы в группе пациентов с положительными данными аллергоанамнеза на ужаление пчелы составила $84,6 \%$, специфичность теста - 83,3\% ( $p<0,001)$ (табл. 1).

Чувствительность определения slgE-AT к яду осы в группе пациентов с положительным анамнезом на ужаление осы составила $62,8 \%$, специфичность $90,0 \%$ (р<0,001) (табл. 2).

Т аблица 1

Чувствительность и специфичность slgE-AT (аллерген яда пчелы)

\begin{tabular}{|c|c|c|c|c|c|c|}
\hline \multirow{2}{*}{\multicolumn{3}{|c|}{ Результат }} & \multirow{3}{*}{$\begin{array}{c}\text { Контроль } \\
25\end{array}$} & \multicolumn{3}{|c|}{ Насекомое } \\
\hline & & & & \multirow{2}{*}{$\frac{\text { Пчела }}{5}$} & \multirow{2}{*}{$\frac{\text { Oca }}{35}$} & \multirow{2}{*}{$\begin{array}{c}\text { Неизвестно } \\
13\end{array}$} \\
\hline \multirow{4}{*}{ пчела } & \multirow[t]{2}{*}{ Отрицательно } & Абс. число & & & & \\
\hline & & $\%$ & 83,3 & 15,4 & 76,0 & 68,4 \\
\hline & \multirow[t]{2}{*}{ Положительно } & Абс. число & 5 & 34 & 9 & 6 \\
\hline & & $\%$ & 16,7 & 84,6 & 21,0 & 31,6 \\
\hline \multicolumn{2}{|l|}{ Всего } & Абс. число & 30 & 39 & 44 & 19 \\
\hline
\end{tabular}

Таблица 2

Чувствительность и специфичность slgE-AT (аллерген яда осы)

\begin{tabular}{|c|c|c|c|c|c|c|}
\hline \multirow{2}{*}{\multicolumn{3}{|c|}{ Результат }} & \multirow{3}{*}{$\begin{array}{c}\text { Контроль } \\
27\end{array}$} & \multicolumn{3}{|c|}{ Насекомое } \\
\hline & & & & \multirow{2}{*}{$\begin{array}{c}\text { Пчела } \\
27\end{array}$} & \multirow{2}{*}{$\frac{\text { Oca }}{8}$} & \multirow{2}{*}{$\begin{array}{c}\text { Неизвестно } \\
9\end{array}$} \\
\hline slgE-AT, oca & Отрицательно & Абс. число & & & & \\
\hline & & $\%$ & 90,0 & 61,3 & 43,2 & 47,4 \\
\hline & \multirow[t]{2}{*}{ Положительно } & Абс. число & 3 & 12 & 36 & 10 \\
\hline & & $\%$ & 10,0 & 38,7 & 62,8 & 52,6 \\
\hline \multicolumn{2}{|l|}{ Всего } & Абс. число & 30 & 39 & 44 & 9 \\
\hline
\end{tabular}


При исследовании уровня slgE-AT к яду шершня наибольшее количество положительных результатов выявлено в подгруппе пациентов с анамнезом на ужаление неизвестного насекомого (34,8\%), что дает основание предположить, что в большинстве случаев в данной подгруппе аллергическая реакция развилась на ужаление шершня. Специфичность теста составила 93,3\% ( $p<0,001)$ (табл. 3).

Чувствительность BASOTEST (BAT) с аллергеном пчелы была сопоставима с определением slgE-AT в группе пациентов с положительным аллергоанамнезом на ужаление пчелы (91,3 и 84,6\% соответственно) (табл. 4).
ВАТ с аллергеном осы была выше по сравнению с результатами ИФА (73,7 и 62,8\% соответственно), но при этом она была ниже по сравнению с чувствительностью ВАТ к аллергену пчелы (73,7 и 91,3\%; $p=0,031)$ (табл. 5).

Наибольшее количество положительных результатов с аллергеном шершня было получено при исследовании активации базофилов в подгруппе пациентов на ужаление неизвестно насекомого $(42,1 \%)$, чуть меньше в подгруппе на ужаление осы $(27,3 \%)$ (табл. 6). Данные по специфичности определения ВАТ были сопоставимы к аллергену пчелы, осы и шершня: 96,7, 96,6, 96,7\% соответственно.

Таблица 3

Чувствительность и специфичность slgE-AT (аллерген яда шершня)

\begin{tabular}{|c|c|c|c|c|c|c|}
\hline \multirow{2}{*}{\multicolumn{3}{|c|}{ Результат }} & \multirow{3}{*}{$\begin{array}{c}\text { Контроль } \\
28\end{array}$} & \multicolumn{3}{|c|}{ Насекомое } \\
\hline & & & & \multirow{2}{*}{$\begin{array}{c}\text { Пчела } \\
30\end{array}$} & \multirow{2}{*}{$\begin{array}{c}\text { Oca } \\
34\end{array}$} & \multirow{2}{*}{$\begin{array}{c}\text { Неизвестно } \\
13\end{array}$} \\
\hline slgE-AT, & Отрицательно & Абс. число & & & & \\
\hline & & $\%$ & 93,3 & 92,3 & 68,2 & 63,2 \\
\hline & \multirow[t]{2}{*}{ Положительно } & Абс. число & 2 & 6 & 10 & 6 \\
\hline & & $\%$ & 6,7 & 9,3 & 25,8 & 34,8 \\
\hline \multicolumn{2}{|l|}{ Всего } & Абс. число & 30 & 39 & 44 & 19 \\
\hline
\end{tabular}

Таблица 4

Чувствительность и специфичность ВАТ (аллерген пчела)

\begin{tabular}{|l|l|c|c|c|c|c|}
\hline \multicolumn{2}{|c|}{ Результат } & \multirow{2}{*}{ Контроль } & \multicolumn{3}{c|}{ Насекомое } \\
\cline { 4 - 7 } & & & Пчела & Оса & Неизвестно \\
\hline \multirow{3}{*}{ BASOTEST, пчела } & \multirow{2}{*}{ Отрицательно } & Абс. число & 29 & 6 & 35 & 15 \\
\cline { 3 - 7 } & & $\%$ & 96,7 & 7,7 & 83,1 & 78,9 \\
\cline { 3 - 7 } & Положительно & Абс. число & 1 & 33 & 9 & 4 \\
\cline { 3 - 7 } & & $\%$ & 3,3 & 91,3 & 14,9 & 21,1 \\
\hline Всего & Абс. число & 30 & 39 & 44 & 19 \\
\hline
\end{tabular}

Таблица 5

Чувствительность и специфичность ВАТ (аллерген оса)

\begin{tabular}{|l|l|c|c|c|c|c|}
\hline \multicolumn{2}{|c|}{ Результат } & \multirow{2}{*}{ Контроль } & \multicolumn{3}{c|}{ Насекомое } \\
\cline { 4 - 7 } & & & Пчела & \multicolumn{2}{|c|}{ Оса } & Неизвестно \\
\hline \multirow{3}{*}{ ВASOTEST, оса } & Отрицательно & Абс. число & 28 & 24 & 10 & 11 \\
\cline { 3 - 7 } & & $\%$ & 96,6 & 53,8 & 24,3 & 57,9 \\
\cline { 3 - 7 } & Положительно & Абс. число & 2 & 15 & 34 & 8 \\
\cline { 3 - 7 } & & $\%$ & 3,4 & 42,2 & 73,7 & 42,1 \\
\hline Всего & Абс. число & 30 & 39 & 44 & 19 \\
\hline
\end{tabular}

Таблица 6

Чувствительность и специфичность ВАТ (аллерген шершень)

\begin{tabular}{|l|l|c|c|c|c|c|}
\hline \multicolumn{2}{|c|}{ Результаты } & \multirow{2}{*}{ Контроль } & \multicolumn{3}{c|}{ Насекомое } \\
\cline { 4 - 7 } & & & Пчела & \multicolumn{2}{|c|}{ Оса } & Неизвестно \\
\hline \multirow{2}{*}{$\begin{array}{l}\text { BASOTEST, шер- } \\
\text { шень }\end{array}$} & Отрицательно & Абс. число & 29 & 37 & 32 & 11 \\
\cline { 3 - 7 } & & $\%$ & 96,7 & 94,9 & 72,7 & 57,9 \\
\cline { 2 - 7 } & Положительно & Абс. число & 1 & 2 & 12 & 8 \\
\cline { 3 - 7 } & & $\%$ & 3,3 & 5,1 & 27,3 & 42,1 \\
\hline Всего & Абс. число & 30 & 39 & 44 & 19 \\
\hline
\end{tabular}


В сыворотке крови пациентов контрольной группы в 5 (16\%) случаях регистрировался повышенный уровень slgЕ-АТ к яду пчелы, в 3 (10\%) случаях - к яду осы и в $2(6 \%)$ - к яду шершня. Положительные данные ВАТ с аллергеном пчелы выявлены у 1 (3\%) пациента, с аллергенами осы - у 2 (6\%) и шершня - у 1(3\%) здорового добровольца.

Заключение. Анализ полученных результатов исследования показал, что BASOTEST по чувствительности и специфичности превосходит диагностические возможности ИФА, основанной на выявлении slgE-AT к ядам перепончатокрылых насекомых. BASOTEST может быть рекомендован для использования в алгоритме диагностики как для первичной идентифрикации причинно-значимого насекомого, так и при наличии сочетанной сенсибилизации как минимум к двум аллергенам по данным определения slgE-AT.

\section{ЛИТЕРАТУРА}

1. Гущин, И.С. Аллергия к насекомым. Клиника, диагностика и лечение / И.С. Гущин, В.Г. Читаева. - М., ФармарусПринт, 2003. - 328 с.

2. Bilò, B.M. EAACI Interest Groupon Insect Venom Hypersensitivity. Diagnosis of Hymenoptera venom allergy / B.M. Bilò, F. Rueff, H. Mosbech [et al.] // Allergy. 2005. - Vol. 60. - P.1339-1349.

3. Bilò, B.M. Epidemiology of insect-venom anaphylaxis / B.M. Bilò, F. Bonifazi // Curr. Opin. Allergy. Clin. Immunol. - 2008. — Vol. 8. - P.330-337.

4. Hausmann, O. Insektengiftallergie - wichtiger Ausloser sind Wespen- und Bienengiftstiche / O. Hausmann, P. Jandus, G. Haeberli [et al.] // Schweiz. Med. Forum. 2010. - Vol. 10. - P.698-704.

5. Johnson, T. Management of stinging insect hypersensitivity: a 5-year retrospective medical record review / T. Johnson, J. Dietrich, L. Hagan // Ann. Allergy. Asthma. Immunol. - 2006. — Vol. 97(2). - P.223-225.

6. Zidarn, M. Anaphylaxis after Hymenoptera sting without detectable specific IgE / M. Zidarn, M. Kosnik, I. Drinovec // Acta Dermatovenerol. Alp. Panonica. Adriat. - 2007. Vol. 16. - P.31-33.

7. Sainte-Laudy, J. Diagnosis of venom allergy by flow cytometry. Correlation with clinical history, skin tests, specific IgE, histamine and leukotriene C4 release / J. Sainte-Laudy, A. Sabbah, M. Drouet [et al.] // Clin. Exp. Allergy. - 2000. - Vol. 30. - P.11661171.

8. Ebo, D.G. Basophil activation test by flow cytometer: present and futureapplications in allergology. Cytometery B / D.G. Ebo, C.H. Bridts, M.M. Hagendorens [et al.] // Clin. Cytom. - 2008. - Vol. 74. - P.201-210.

9. Peternelj, A. Basophil activation test (BAT) in «in vitro» diagnosis of hymenoptera venom hypersensitivity / A. Peternelj, M. Šilar, R. Eržen [et al.] // Zdravn. Vest. 2008. - Vol. 77. - P.183-187.

10. Sturm, G.J. The CD63 basophil activation test in Hymenoptera venom allergy: a prospective study / G.J. Sturm, E. Bohm, M. Trummer [et al.] // Allergy. 2004. - Vol. 59. - P.1110-1117.

11. Peternelj, A. Diagnostic value of the basophil activation test in evaluating Hymenoptera venom sensitization / A. Peternelj, M. Silar, N. Bajrovic [et al.] // Wien. Klin. Wochenschr. - 2009. — Vol. 121(9-10). P.344.
12. Erdmann, S.M. The basophil activation test in wasp venom allergy: sensitivity, specifi city and monitoring specifi c immunotherapy / S.M. Erdmann, B. Sachs, R. Kwiecien [et al.] // Allergy. - 2004. - Vol. 59. P.1102-1109.

13. Gober, L.M. Expression of activation markers on basophils in a controlled model of anaphylaxis / L.M. Gober, J.A. Eckman, P.M. Sterba [et al.] // J. Allergy. Clin. Immunol. — 2007. — Vol. 119(5). - P.1181-1188.

\section{REFERENCES}

1. Guschin, I.S. Allergiya k nasekomym. Klinika, diagnostika i lechenie [Allergy to insects. Clinical features, diagnosis and treatment ] / I.S. Guschin, V.G. CHitaeva. - M., FarmarusPrint, 2003. - $328 \mathrm{~s}$.

2. Bilò, B.M. EAACI Interest Groupon Insect Venom Hypersensitivity. Diagnosis of Hymenoptera venom allergy / B.M. Bilò, F. Rueff, H. Mosbech [et al.] // Allergy. 2005. - Vol. 60. - P.1339-1349.

3. Bilò, B.M. Epidemiology of insect-venom anaphylaxis / B.M. Bilò, F. Bonifazi // Curr. Opin. Allergy. Clin. Immunol. — 2008. - Vol. 8. - P.330-337.

4. Hausmann, O. Insektengiftallergie - wichtiger Ausloser sind Wespen- und Bienengiftstiche / O. Hausmann, P. Jandus, G. Haeberli [et al.] // Schweiz. Med. Forum. 2010. - Vol. 10. - P.698-704.

5. Johnson, T. Management of stinging insect hypersensitivity: a 5-year retrospective medical record review / T. Johnson, J. Dietrich, L. Hagan // Ann. Allergy. Asthma. Immunol. - 2006. - Vol. 97(2). - P.223-225.

6. Zidarn, M. Anaphylaxis after Hymenoptera sting without detectable specific IgE / M. Zidarn, M. Kosnik, I. Drinovec // Acta Dermatovenerol. Alp. Panonica. Adriat. - 2007. Vol. 16. - P.31-33.

7. Sainte-Laudy, J. Diagnosis of venom allergy by flow cytometry. Correlation with clinical history, skin tests, specific IgE, histamine and leukotriene C4 release / J. Sainte-Laudy, A. Sabbah, M. Drouet [et al.] // Clin. Exp. Allergy. - 2000. - Vol. 30. - P.11661171.

8. Ebo, D.G. Basophil activation test by flow cytometer: present and futureapplications in allergology. Cytometery B / D.G. Ebo, C.H. Bridts, M.M. Hagendorens [et al.] // Clin. Cytom. - 2008. - Vol. 74. - P.201210.

9. Peternelj, A. Basophil activation test (BAT) in «in vitro» diagnosis of hymenoptera venom hypersensitivity / A. Peternelj, M. Šilar, R. Eržen [et al.] // Zdravn. Vest. 2008. - Vol. 77. - P.183-187.

10. Sturm, G.J. The CD63 basophil activation test in Hymenoptera venom allergy: a prospective study / G.J. Sturm, E. Bohm, M. Trummer [et al.] // Allergy. 2004. - Vol. 59. - P.1110-1117.

11. Peternelj, A. Diagnostic value of the basophil activation test in evaluating Hymenoptera venom sensitization / A. Peternelj, M. Silar, N. Bajrovic [et al.] // Wien. Klin. Wochenschr. - 2009. - Vol. 121(9-10). - P.344

12. Erdmann, S.M. The basophil activation test in wasp venom allergy: sensitivity, specifi city and monitoring specifi c immunotherapy / S.M. Erdmann, B. Sachs, R. Kwiecien [et al.] // Allergy. - 2004. - Vol. 59. P.1102-1109.

13. Gober, L.M. Expression of activation markers on basophils in a controlled model of anaphylaxis / L.M. Gober, J.A. Eckman, P.M. Sterba [et al.] // J. Allergy. Clin. Immunol. - 2007. - Vol. 119(5). - P.1181-1188.

Принята 27.10.2014 


\title{
ВНЕЛЕГОЧНЫЙ ТУБЕРКУЛЕЗ У ДЕТЕЙ ЗА 20-ЛЕТНИЙ ПЕРИОД НАБЛЮДЕНИЯ
}

АННА АНАТОЛЬЕВНА ТУРИЦА, канд. мед. наук, доцент кафедры пропедевтики детских болезней и поликлинической педиатрии ГБОУ ВПО «Омская государственная медицинская академия» Минздрава России, Омск, Россия, тел. 8-913-961-69-25, e-mail: turi8282@mail.ru

НАДЕЖДА ИГОРЕВНА ПОРКУЛЕВИЧ, ординатор кафедры фтизиатрии и фтизиохирургии ГБОУ ВПО «Омская государственная медицинская академия» Минздрава России, Омск, Россия, тел. 8-908-107-30-73, e-mail: www.nkul@mail.ru

ЕЛЕНА АНАТОЛЬЕВНА ЦЫГАНКОВА, канд. меД. наук, зав. отделением КУЗОО «Специализированная детская туберкулезная клиническая больница», Омск, Россия, тел. 8-913-634-14-13, e-mail: 6341413@mail.ru

\begin{abstract}
Реферат. Цель исследования - оценка внелегочных проявлений туберкулеза у детей за 20-летний период на материале Омской области. Материал и методы. Проведено ретроспективное исследование среди 1637 детей, больных туберкулезом, за период с 1994 по 2013 г. Сформированы две группы сравнения: I (с 1994 по 2003 г.) 774 ребенка; II (с 2004 по 2013 г.) - 863 ребенка. Результаты и их обсуждение. Отмечено увеличение среди заболевших туберкулезом в период с 2004 по 2013 г. детей раннего возраста $\left(X^{2}=14,537 ; p=0,000\right)$, снижение доли изолированных внелегочных форм с 11,0 до 4,5\% случаев $\left(X^{2}=23,429 ; p=0,000\right)$, рост изолированного поражения мочевыделительной системы с 57,6 до $71,8 \%\left(X^{2}=7,996 ; p=0,005\right)$, увеличение генерализаций процесса в 2,3 раза $\left(X^{2}=10,395 ; p=0,001\right)$, бактериовыделения при генерализованных формах в 4 раза $\left(X^{2}=4,206 ; p=0,040\right)$. Наиболее частым вариантом сочетаний было сочетание туберкулеза почек и внутригрудных лимфатических узлов. Заключение. В последнее десятилетие (2004-2013 гг.) в Омской области у детей от 0 до 14 лет установлен отрицательный патоморфоз туберкулеза, что позволяет охарактеризовать эпидемиологическую ситуацию по туберкулезу как сохраняющую напряженность.
\end{abstract}

Ключевые слова: внелегочный туберкулез, клинические формы, дети.

\section{EXTRAPULMONARY TUBERCULOSIS IN CHILDREN: THE 20-YEAR OBSERVATION}

\begin{abstract}
ANNA A. TURITSA, Ph.D., associate professor of Department of outpatient pediatrics of SBEI HPE «Omsk State Medical Academy» of Russian Ministry of Health, Omsk, Russia, tel. 8-913-961-69-25, e-mail: turi8282@mail.ru NADEZHDA I. PORKULEVICH, resident of Department of tuberculosis and surgery of SBEI HPE «Omsk State Medical Academy» of Russian Ministry of Health, Omsk, Russia, tel. 8-908-107-30-73, e-mail: www.nkul@mail.ru ELENA A. TSYGANKOVA, Ph.D., Head of Department of «Specialized Children's Tuberculosis Hospital», Omsk, Russia, tel. 8-913-634-14-13, e-mail: 6341413@mail.ru
\end{abstract}

\begin{abstract}
Aim. To evaluate the extrapulmonary manifestations of tuberculosis in children over a 20 year period in the Omsk region. Material and methods. A retrospective study of 1637 children with TB, for the period from 1994 to 2013 was performed. We formed two comparison groups: I (1994 to 2003) - 774 children and II (2004 to 2013) 863 children. Results. Demonstrated that in the period from 2004 to 2013 infants had an increase of tuberculosis $\left(X^{2}=14,537 ; p<0,05\right)$, decrease in the percentage of isolated extrapulmonary forms from 11,0 to $4,5 \%$ of cases $\left(X^{2}=23,429 ; p<0,05\right)$, the growth of isolated lesions of the urinary system from 57,6 to $71,8 \%\left(X^{2}=7,996 ; p=0,005\right)$, an increase of generalizations process 2,3 times $\left(X^{2}=10,395 ; p=0,001\right)$, bacterial isolation in generalized forms 4 times $\left(X^{2}=4,206 ; p=0,04\right)$. The most frequent combination was the combination of renal tuberculosis and hilar lymph nodes tuberculosis. Conclusion. The last decade (2004-2013) in the Omsk region in children from 0 to 14 years was characterized by negative pathomorphosis of tuberculosis, which allows us to conclude the epidemiological situation of tuberculosis as in particular strain.
\end{abstract}

Key words: extra-pulmonary tuberculosis, clinical forms, children.

$\mathrm{T}$ уберкулез, несмотря на все усилия со стороны отечественной и зарубежной медицинской общественности, органов власти и международных организаций, остается весьма актуальной проблемой $[3,6]$. Почти половина впервые выявленных пациентов с деструктивным и запущенным туберкулезом умирает от прогрессирования туберкулеза легких, а внелегочный туберкулез остается недиагностированным на фоне манифестных симптомов поражения бронхолегочной системы $[4,10]$. Несмотря на снижение заболеваемости и смертности от туберкулеза, в ряде федеральных округов эпидемическая ситуация сохраняет напряженность [3]. При этом практически не изменяются величины показателей заболеваемости внелегочным туберкулезом, эти пациенты составляют около 3-4\% от всех впервые выявленных больных туберкулезом $[4,10,11]$. Отсутствие скрининговых методов выявления внелегочного туберкулеза делают проблему нерешенной, невыявление заболевания на ранних стадиях доставляет страдания пациентам [5, 11].

В настоящее время практически на прежнем уровне, без выраженной тенденции к снижению сохраняются показатели детской и подростковой заболеваемости $[1,7,9]$. Многие авторы это связывают с совершенствованием диагностики, внедрением Диаскинтеста и предполагают улучшение структуры клинических форм у больных туберкулезом детей [1, 8, 9]. Вместе с тем есть работы, показывающие серьезность ситуации, наличие тяжелых генерализованных форм туберкулеза у детей, случаев врожденного туберкулеза [2, 7]. При этом недостаточно внимания 
уделяется анализу заболеваемости внелегочным туберкулезом у детей, особенно в условиях разнонаправленных и в последние годы положительных тенденций в развитии эпидемиологической ситуации в течение длительного периода наблюдения.

Цель исследования - оценка доли внелегочных проявлений туберкулеза в структуре детской заболеваемости туберкулезом в сравнительном аспекте для совершенствования оценки эпидемиологической ситуации.

Материал и методы. Проведено ретроспективное исследование среди 1637 детей в возрасте от 0 до 14 лет, больных туберкулезом и проходивших стационарный курс лечения в период с 1993 по 2013 г. в Казенном учреждении здравоохранения Омской области «Специализированная детская туберкулезная клиническая больница». Критерии включения в исследование: активный туберкулезный процесс любых локализаций (IA группа диспансерного учета), возраст 0-14 лет. Была проанализирована структура клинических форм туберкулеза и сформированы две группы сравнения в соответствии с десятилетними временными периодами (I период с 1994 по 2003 г. - 774 ребенка; II период с 2004 по 2013 г. - 863 ребенка).

Полученные в ходе исследования данные статистически обработаны с помощью пакета прикладных программ «Microsoft Office 2007», Biostat 2009. Различия между группами определялись с использованием критерия $\mathrm{X}^{2}$, результаты считались достоверными при $p<0,05$.

Результаты и их обсуждение. Дети в группах распределились по возрасту следующим образом: в первом десятилетии детей в возрасте 0-3 года было $11,6 \%$, а во втором - 18,5\% ( $x^{2}=14,537$; $p<0,05)$, в возрасте 4-6 лет - 27,9 и 27,3\% $\left(X^{2}=0,039 ; p=0,843\right)$, в возрасте 7-11 лет - 38,5 и $30,4 \%$ ( $\left.x^{2}=11,660 ; p=0,000\right), 7-14$ лет - 22 и 23,8\% $\left(X^{2}=0,643 ; p=0,423\right)$ соответственно.

У детей в группах сравнения преобладал туберкулез органов дыхания, на долю изолированных внелегочных фрорм приходилось $11,0 \%$ в I группе (85 человек) и 4,5\% случаев (39 детей) во II группе $\left(\mathrm{X}^{2}=23,429 ; p<0,05\right)$ (табл. 1). У детей с внелегочным туберкулезом бактериовыделение в первом десятилетии установлено у каждого пятого ребенка, а во втором десятилетии - у каждого четвертого $\left(x^{2}=2,647 ; p=0,104\right)$.

Среди локализаций внелегочного процесса на первом месте в обеих группах было поражение мочевыделительной системы $(57,6$ и 71,8\% в группах соответственно) $\left(X^{2}=7,996 ; p=0,005\right)$. Поражение периферических лимфоузлов во втором десятилетнем периоде развивалось реже в 5 раз $\left(X^{2}=15,300\right.$; $p<0,05)$. Туберкулез костей и суставов в последнее десятилетие встречался чаще в 2,5 раза $\left(X^{2}=0,039\right.$; $p=0,844)$. Абдоминальный туберкулез в 4 раза чаще встречался в первом десятилетии $\left(X^{2}=5,743 ; p=0,017\right)$. Самой редкой локализацией (по одному случаю в обеих группах сравнения) было туберкулезное поражение кожи и подкожной клетчатки.

При анализе структуры клинических форм туберкулеза у детей разного возраста установлено (табл. 2), что изолированный внелегочный туберкулез чаще встречался в группе пациентов в возрасте 7-11 лет и 12-14 лет первого анализируемого десятилетнего периода $\left(X^{2}=14,364 ; p=0,000\right.$ и $X^{2}=4,051$; $p=0,044$ соответственно). Бактериовыделение среди изолированных внелегочных форм отмечалось чаще во II группе детей (2004-2013 гг.): в 66,7\% случаев

Та блица 1

Структура локализаций изолированного внелегочного туберкулеза в сравниваемые временные периоды

\begin{tabular}{|l|r|r|r|r|}
\hline \multicolumn{1}{|c|}{ Структура } & $\begin{array}{c}\text { I группа (1994-2003 гг.) } \\
\text { абс.ч. (\%) }\end{array}$ & $\begin{array}{c}\text { II группа (2004-2013 гг.) } \\
\text { абс.4. (\%) }\end{array}$ & $X^{2}$ & $p$ \\
\hline Изолированный внелегочный туберкулез, из них & $85(100)$ & $39(100)$ & 23,429 & $<0,05$ \\
\hline МБТ (+) & $18(21,2)$ & $10(25,6)$ & 2,647 & 0,104 \\
\hline Мочевой системы & $49(57,6)$ & $28(71,8)$ & 7,996 & 0,005 \\
\hline Периферических лимфоузлов & $20(23,5)$ & $2(5,1)$ & 15,300 & $<0,05$ \\
\hline Костей и суставов & $6(7,1)$ & $7(17,9)$ & 0,039 & 0,844 \\
\hline Абдоминальный & $9(10,6)$ & $1(2,6)$ & 5,743 & 0,017 \\
\hline Кожи и подкожной клетчатки & $1(1,2)$ & $1(2,6)$ & 0,399 & 0,528 \\
\hline
\end{tabular}

Таблица 2

Возрастная структура клинических форм изолированного внелегочного туберкулеза в сравниваемые временные периоды

\begin{tabular}{|c|c|c|c|c|c|c|c|}
\hline \multirow[b]{2}{*}{ Возраст, лет } & \multirow[b]{2}{*}{ Года, группа } & \multicolumn{6}{|c|}{ Локализация туберкулеза } \\
\hline & & $\begin{array}{c}\text { Мочевая } \\
\text { система, \% }\end{array}$ & $\begin{array}{c}\text { Периферические } \\
\text { лимфоозлы, \% }\end{array}$ & $\begin{array}{c}\text { Кости } \\
\text { и суставы, \% }\end{array}$ & $\begin{array}{c}\text { Органы брюшной } \\
\text { полости, \% }\end{array}$ & Кожа, \% & МБТ+, \% \\
\hline \multirow[t]{2}{*}{ От 0 до 3} & $1994-2003(n=2)$ & 0 & 50,0 & 0 & 0 & 50,0 & 0 \\
\hline & $2004-2013(n=5)$ & 0 & 20 & 80 & 0 & 0 & 0 \\
\hline \multirow[t]{2}{*}{ От 4 до 6} & $1994-2003(n=12)$ & 50,0 & 8,3 & 8,3 & 33,3 & 0 & 25,0 \\
\hline & $2004-2013(n=3)$ & 0 & 33,3 & 33,3 & 0 & 33,3 & 66,7 \\
\hline \multirow[t]{2}{*}{ От 7 до 10} & $1994-2003(n=45)$ & 60,0 & 2,2 & 8,9 & 8,9 & 0 & 17,8 \\
\hline & $2004-2013(n=13)$ & 84,6 & 0 & 15,4 & 0 & 0 & 38,5 \\
\hline \multirow[t]{2}{*}{ От 11 до 14} & 1994-2003 $(n=26)$ & 61,5 & 30,8 & 3,8 & 3,8 & 0 & 26,9 \\
\hline & $2004-2013(n=18)$ & 94,5 & 0 & 0 & 5,5 & 0 & 16,7 \\
\hline
\end{tabular}


среди детей 4-6 лет ( $\left.X^{2}=0,010 ; p=0,921\right)$, в 38,5\% случаев среди детей $7-10$ лет $\left(X^{2}=0,107 ; p=0,743\right)$ и в 16,7\% случаев среди детей 11-14 лет ( $x^{2}=1,603$; $p=0,205)$. В структуре изолированного внелегочного туберкулеза в разных возрастных группах на долю туберкулеза мочевой системы приходилось от 50 до $94,5 \%$, эта локализация специфического процесса чаще наблюдалась у пациентов 11-14 лет и младших школьников, чем у пациентов дошкольного возраста $\left(X^{2}=4,692 ; p=0,030\right)$. У детей раннего возраста II группы сравнения (2004-2013 гг.) недостоверно чаще других из изолированных внелегочных локализаций специфического процесса диагностировали туберкулез костей и суставов $\left(X^{2}=0,974 ; p=0,324\right)$.

Нами оценивалось наличие внелегочного туберкулеза в структуре генерализаций туберкулезного процесса. Количество детей с генерализованным туберкулезом среди всех заболевших туберкулезом детей в последнее десятилетие увеличилось в 2,3 раза, с $28(3,6 \%)$ до $64(7,4 \%)$ случаев $\left(X^{2}=10,395\right.$; $p=0,001)$. Бактериовыделение при генерализованных фрормах увеличилось в 4 раза, с 3,6 до 14,0\% $\left(X^{2}=4,206 \% ; p=0,040\right)$. При этом количество детей с менингоэнцефалитами в качестве единственного зарегистрированного проявления инфекции уменьшилось с 6 случаев в период с 1994 по 2003 г. до 2 случаев в период с 2004 по 2013 г. $\left(x^{2}=8,219\right.$; $p=0,003)$. Но в последний десятилетний период зарегистрирован один случай врожденного туберкулеза с поражением органов дыхания и центральной нервной системы. На сочетание туберкулеза органов дыхания и внеторакальных локализаций приходилось в оба периода 64,3\% (18 детей) и 92,1\% случаев (59 детей) $\left(X^{2}=11,112 ; p<0,05\right)$. Структура сочетаний туберкулеза органов дыхания, представленная туберкулезом внутригрудных лимфатических узлов и первичным туберкулезным комплексом с различными вариантами внелегочного туберкулеза представлена на рисунке. Наиболее частым вариантом сочетаний во втором временном периоде было сочетание туберкулеза почек и внутригрудных лимфатических узлов, на которое пришлось 54,2\% всех вариантов полиорганного туберкулеза.

Значительное преобладание в структуре внелегочных фрорм и полиорганного туберкулеза у детей на протяжении 20 лет в Омской области является особенностью региона. Хотя, по мнению профессора Е.В. Кульчавени (2013), до 2012 г. включительно на территории Сибирского фредерального округа в структуре внелегочных фрорм отмечалось незначительное преобладание мочеполового туберкулеза, который в структуре всех локализаций туберкулеза занимал второе место после туберкулеза легких [4]. По мнению Е.В. Кульчавени, этот фракт можно объяснить климатическими особенностями округа, делающими мочеполовую систему более уязвимой к различным инфекциям, в том числе и специфическим.

Заключение. В последнее десятилетие (20042013 гг.) по сравнению с первым изучаемым периодом (1994-2004 гг.) в Омской области у детей от 0 до 14 лет установлен отрицательный патоморфоз туберкулеза, который характеризуется увеличением среди заболевших детей раннего возраста, ростом доли генерализованных форм, регистрацией случая

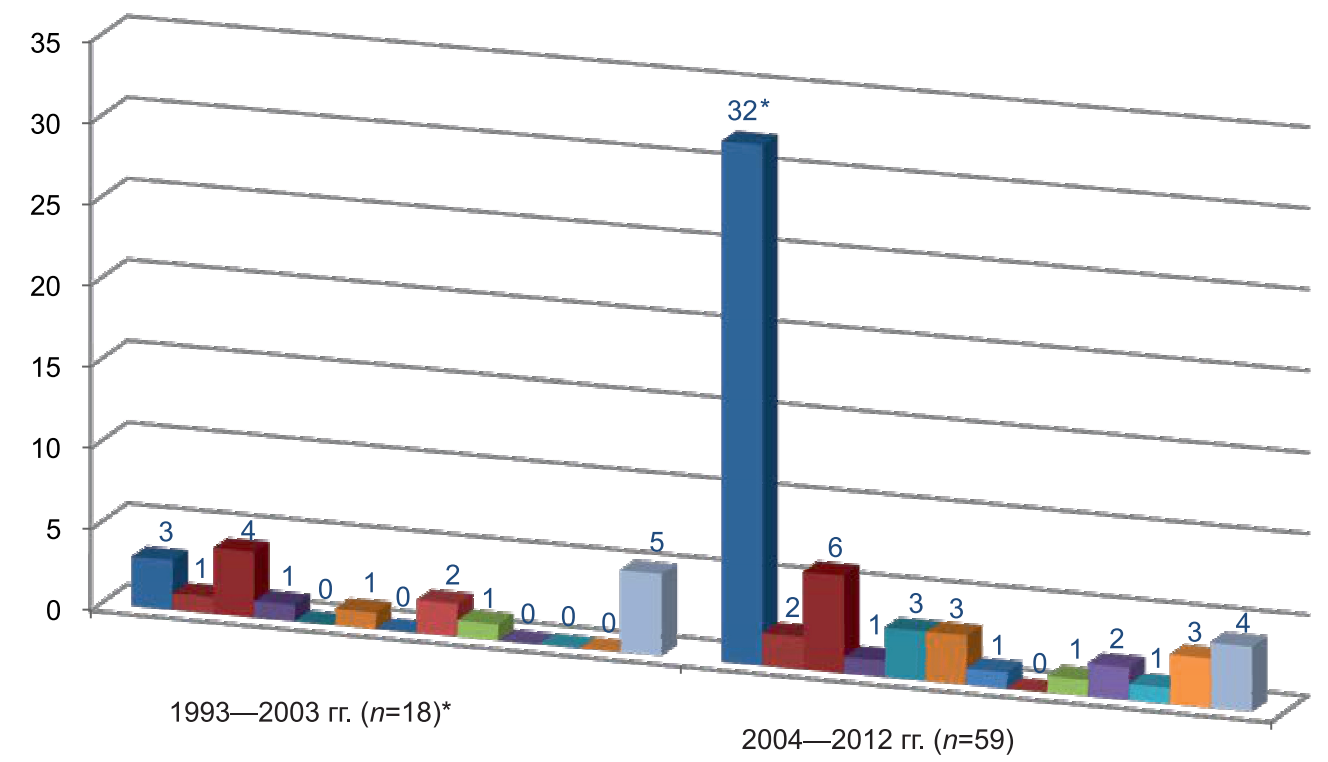

- ТВЛУ $+\mathrm{MBC}$

- ТВЛУ+менингит

- ПТК+кожа

- ИТЛ+МВС

口более 2 локализаций
- ТВЛУ+абдоминальный

-ТВЛУ+кости

- ПТК+периферические лимфоузлы

пИТЛ+периферические лимфоузлы
- ТВЛУ+перифрерические лимфоузлы $\square \mathrm{ITK}+\mathrm{MBC}$

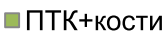

口диссемин.+менингоэнцефалит

Структура сочетания туберкулеза органов дыхания и внелегочного туберкулеза в сравниваемые временные периоды (ТВЛУ - туберкулез внутригрудных лимфратических узлов; MBC - туберкулез мочевыделительной системы; ПТК — первичный туберкулезный комплекс) 
врожденного туберкулеза, увеличением частоты бактериовыделения среди пациентов с внелегочными фрормами туберкулеза. Об отрицательном характере изменений также свидетельствует уменьшение числа случаев изолированного внелегочного туберкулеза при большем количестве его сочетаний с туберкулезом органов дыхания. Региональной особенностью является значительное преобладание над остальными локализациями туберкулеза мочевыделительной системы у детей. Таким образом, выявленные особенности позволяют охарактеризовать эпидемиологическую ситуацию по туберкулезу как сохраняющую напряженность с отсутствием за 10-летний период положительных тенденций к фрормированию благоприятной структуры заболеваемости детей.

\section{ЛИТЕРАТУРА}

1. Аксенова, В.А. Туберкулез у детей в России и задачи фтизиатрической общей педиатрической службы по профилактике и раннему выявлению заболевания / В.А. Аксенова, Л.А. Барышникова, Т.А. Севастьянова, Н.И. Клевно // Туберкулез и болезни легких. - 2014. T. 91, № 3. - С.40-46.

2. Клиническое наблюдение врожденного туберкулеза у новорожденного ребенка / А.В. Лысов [и др.] // Туберкулез и болезни легких. - 2010. - Т. 87, № 4. C.54-57.

3. Краснов, В.А. Факторы, препятствующие улучшению ситуации по туберкулезу в субъектах Сибирского федерального округа / В.А. Краснов, В.М. Чернышев, О.В. Стрельченко [и др. ] // Туберкулез и болезни легких. - 2012. - Т. 89, № 10. - С.8-14.

4. Кульчавеня, Е.В. Современные тенденции эпидемической ситуации по внеторакальному туберкулезу / Е.В. Кульчавеня, В.А. Краснов, С.Н. Скорняков [и др.] // Туберкулез и болезни легких. - 2013. - Т. 90, № 12. - С.34-39.

5. Кульчавеня, Е.В. Дифференциальная диагностика туберкулеза мочеполовой системы / Е.В. Кульчавеня, Д.П. Холтобин // Туберкулез и болезни легких. 2013. - Т. 90, № 7. - С.3-8.

6. Мордык, А.В. Современные международные и национальные концепции борьбы с туберкулезом / А.В. Мордык, Л.В. Пузырева, Л.П. Аксютина // Дальневосточный журнал инфекционной патологии. 2013. — № 22(22). - С.92-97.

7. Мордык, А.В. Характеристика случаев заболевания туберкулезом детей на территории Омской области за период с 2007 по 2012 г. / А.В. Мордык, Л.В. Пузырева, А.А. Турица // Биозащита и биобезопасность. 2013. - T. 5, № 4(17). - С.18-20.

8. Мордык, А.В. Туберкулез у детей Российской Федерации на современном этапе / А.В. Мордык, Е.А. Цыганкова, Л.В. Пузырева, А.А. Турица // Педиатрическая фармакология. - 2014. - Т. 11, № 3. - С.27-30

9. Нечаева, О.Б. Эпидемическая ситуация по туберкулезу среди детей России / О.Б. Нечаева // Туберкулез и болезни легких. - 2013. - Т. 90, № 6. - С.62-63.

10. Нечаева, О.Б. Эпидемическая ситуация по внелегочному туберкулезу в Российской Федерации / О.Б. Нечаева, В.В. Скачков // Туберкулез и болезни легких. 2013. - Т. 90, № 8. - С.3-9.

11. Пузырева, Л.В. Эпидемическая ситуация по внелегочному туберкулезу в Омской области за десятилетний период наблюдения (2003-2012 гг.) / Л.В. Пузырева, А.В. Мордык // Медицина и образование Сибири. 2013 - № 5 - C.9.

\section{REFERENCES}

1. Aksenova, V.A. Tuberkulez u detei $v$ Rossii i zadachi ftiziatricheskoi obschei pediatricheskoi sluzhby po profilaktike i rannemu vyyavleniyu zabolevaniya [Tuberculosis in children in Russia and the problem of TB general pediatric services for prevention and early detection of the disease] / V.A. Aksenova, L.A. Baryshnikova, T.A. Sevast'yanova, N.I. Klevno // Tuberkulez i bolezni legkih [Tuberculosis and Lung Disease]. — 2014. - T. 91, № 3. — S.40-46.

2. Klinicheskoe nablyudenie vrozhdennogo tuberkuleza u novorozhdennogo rebenka [Clinical observation of congenital tuberculosis in a newborn baby] / A.V. Lysov [i dr.] // Tuberkulez i bolezni legkih [Tuberculosis and Lung Disease]. — 2010. — T. 87, № 4. - S.54-57.

3. Krasnov, V.A. Faktory, prepyatstvuyuschie uluchsheniyu situacii po tuberkulezu v sub'ektah Sibirskogo federal'nogo okruga [Obstacles to improved TB situation in the subjects of the Siberian Federal District] / V.A. Krasnov, V.M. CHernyshev, O.V. Strel'chenko [i dr. ] // Tuberkulez i bolezni legkih [Tuberculosis and Lung Disease]. 2012. - T. 89, № 10. - S.8-14.

4. Kul'chavenya, E.V. Sovremennye tendencii epidemicheskoi situacii po vnetorakal'nomu tuberkulezu [Modern trends in the epidemiological situation of tuberculosis extrathoracic] / E.V. Kul'chavenya, V.A. Krasnov, S.N. Skornyakov [i dr.] // Tuberkulez i bolezni legkih [Tuberculosis and Lung Disease]. - 2013. - T. 90, № 12. - S.34-39.

5. Kul'chavenya, E.V. Differencial'naya diagnostika tuberkuleza mochepolovoi sistemy [Differential diagnosis of urogenital tuberculosis] / E.V. Kul'chavenya, D.P. Holtobin // Tuberkulez i bolezni legkih [Tuberculosis and Lung Disease]. - 2013. - T. 90, № 7. - S.3-8.

6. Mordyk, A.V. Sovremennye mezhdunarodnye i nacional'nye koncepcii bor'by $s$ tuberkulezom [The modern concept of international and national TB control] / A.V. Mordyk, L.V. Puzyreva, L.P. Aksyutina // Dal'nevostochnyi zhurnal infekcionnoi patologii [Far East Journal of Infectious Pathology]. — 2013. — № 22(22). - S.92-97.

7. Mordyk, A.V. Harakteristika sluchaev zabolevaniya tuberkulezom detei na territorii Omskoi oblasti za period s 2007 po $2012 \mathrm{~g}$. [Characteristics of cases of tuberculosis of children in the Omsk region in the period from 2007 to 2012] / A.V. Mordyk, L.V. Puzyreva, A.A. Turica // Biozaschita i biobezopasnost' [Biosecurity and Biosafety]. - 2013. T. 5, № 4(17). - S.18-20.

8. Mordyk, A.V. Tuberkulez u detei Rossiiskoi Federacii na sovremennom etape [Tuberculosis in children of the Russian Federation at the present stage] / A.V. Mordyk, E.A. Cygankova, L.V. Puzyreva, A.A. Turica // Pediatricheskaya farmakologiya [Pediatric pharmacology]. — 2014. - T. 11, № 3. - S.27-30.

9. Nechaeva, O.B. Epidemicheskaya situaciya po tuberkulezu sredi detei Rossii Epidemiological situation of tuberculosis among children in Russia] / O.B. Nechaeva // Tuberkulez i bolezni legkih [Tuberculosis and Lung Disease]. 2013. - T. 90, № 6. - S.62-63.

10. Nechaeva, O.B. Epidemicheskaya situaciya po vnelegochnomu tuberkulezu v Rossiiskoi Federacii [The epidemiological situation of extrapulmonary tuberculosis in the Russian Federation] / O.B. Nechaeva, V.V. Skachkov // Tuberkulez i bolezni legkih [Tuberculosis and Lung Disease]. - 2013. - T. 90, № 8. - S.3-9.

11. Puzyreva, L.V. Epidemicheskaya situaciya po vnelegochnomu tuberkulezu v Omskoi oblasti za desyatiletnii period nablyudeniya (2003-2012 gg.) [The epidemiological situation of extrapulmonary tuberculosis in the Omsk region of the ten-year period of observation (2003-2012 year)] / L.V. Puzyreva, A.V. Mordyk // Medicina i obrazovanie Sibiri [Medicine and education in Siberia]. 2013. - № 5. - S.9.

Принята 27.08.2014 


\title{
ОПЫТ ЛЕЧЕНИЯ ЭРОЗИВНЫХ ТОЛСТОКИШЕЧНЫХ КРОВОТЕЧЕНИЙ
}

ильсУР МАНСУРОвич ФАТХУтдинов, канд. мед. наук, доцент кафедры хирургических болезней № 1 ГБОУ ВПО «Казанский государственный медицинский университет» Минздрава России, Казань, Россия, тел. 8-917-287-69-99, e-mail: ilsur1801@ mail.ru

\begin{abstract}
Реферат. Цель исследования — определить оптимальную схему диагностики и комплексного лечения эрозивных толстокишечных кровотечений, оценить эффективность проводимого лечения. Материал и методы. За период с 2010 по 2014 г. в клинике хирургии № 1 на базе ГАУЗ «Центральная городская клиническая больница № 18» г. Казани наблюдалось 18 пациентов с эрозивными толстокишечными кровотечениями: 14 (77,8\%) женщин и 4 $(22,2 \%)$ мужчины в возрасте от 17 до 60 лет. Результаты. Во всех наблюдениях отмечен быстрый гемостатический эффект и улучшение качества жизни больных от проводимого комплексного лечения. На сроках после 8 нед во всех наблюдениях эрозии эпителизировались. Выводы. Таким образом, комплексная гемостатическая терапия эрозивных толстокишечных кровотечений с применением препаратов «Салофальк», «Мукофральк» и «Закофальк» позволяет добиться остановки кровотечения и нормализации стула в короткие сроки и тем самым улучшить качество жизни пациентов.
\end{abstract}

Ключевые слова: диагностика, комплексное лечение, эрозивное толстокишечное кровотечение.

\section{EXPERIENCE OF EROSIVE COLONIC BLEEDING TREATMENT}

ILSUR M. FATKHUTDINOV, Ph.D., associate professor of Department of surgical diseases № 1 of SBEl HPE «Kazan State Medical University» of the Ministry of Health of the Russian Federation, Kazan, Russia, tel. 8-917-287-69-99, e-mail: ilsur1801@mail.ru

Abstract. The aim of study: to determine the optimal scheme of diagnosis and complex treatment of erosive colonic bleeding, evaluate the effectiveness of the treatment. Material and methods: 18 patients (14 (77,8\%) women and $4(22,2 \%)$ of men aged 17 to 60 years) with erosive colonic bleeding were observed from 2010 to 2014 . Results. A haemostatic effect and improving the quality of life of patients from the ongoing complex treatment were observed in all cases. Epithelialization of erosions noted at all the patients after 8 weeks. Conclusion. Complex haemostatic therapy (salofalk, mucofalk and zakofalk) of an erosive colonic bleeding allows stopping bleeding and normalization of the clinical picture in the short term.

Key words: diagnosis, comprehensive treatment, erosive colonic bleeding.

$\mathrm{B}^{\mathrm{B}}$ ведение. Острые толстокишечные кровотечения продолжают оставаться одной из серьезных проблем неотложной хирургии. [1]. Хотя частота профузных кровотечений из толстой кишки меньше, чем из верхних отделов ЖКТ, летальность при данном осложнении достигает 15-20\% [2, 3, 4].

Как правило, начало болезни пациенты связывают с перенесенным стрессом. Вначале возникает учащенный жидковатый стул, в дальнейшем появляется примесь крови на/в кале [1, 3]. При этом пациенты не сразу обращаются к врачу, в надежде, что кровь остановится самостоятельно. Поэтому болезнь постепенно прогрессирует [1].

Такие пациенты госпитализируются в отделения неотложной хирургии, где, как правило, проводится традиционная гемостатическая терапия, схожая с лечением кровотечений из верхних этажей желудочно-кишечного тракта, которая бывает не эффрективна при эрозивных толстокишечных кровотечениях [1, 2]. Данная проблема требует выработки схемы лечения с учетом особенностей заболеваний толстой кишки.

Материал и методы. За период с 2010 по 2014 г. в клинике хирургии № 1 на базе Центральной городской клинической больницы № 18 г. Казани наблюдалось 18 пациентов с эрозивными толстокишечными кровотечениями, из них $14(77,8 \%)$ женщин и 4 $(22,2 \%)$ мужчины в возрасте от 17 до 60 лет.

Длительность заболевания варьировала от нескольких часов до трех суток. Все пациенты свя- зывали начало болезни с перенесенным стрессом (проблемы в семье, личной жизни, на работе, смена места жительства).

Всем больным в приемном отделении проводилась клинико-лабораторная диагностика, пальцевое исследование прямой кишки, ЭКГ, осмотр терапевта, после короткой подготовки - колоноскопия. При обнаружении крови на перчатке и эрозий толстой кишки больные госпитализировались в отделение хирургии, где начинали проводить внедренную нами в неотложную хирургию схему комплексного лечения. Терапия включала помимо традиционной гемостатической терапии назначение гранул салофалька в дозе 3 г утром, салофралька в суппозиториях по 500 мг 2 раза в день, мукофалька в стандартной дозировке, диетический стол № 4В. На фоне проводимого лечения наблюдалось прекращение выделения крови с калом, урежение и нормализация количества актов дефекации в сроки от 1 до 3 дней. На 3-5-й день больные отмечали значительное улучшение своего состояния. После контрольных анализов крови и мочи пациенты выписывались домой с рекомендациями продолжения лечения препаратом «Салофальк» до 8 нед, препаратом «Мукофальк» до 4 нед с последующей заменой его препаратом «Закофальк» курсом 4 нед. По истечении 8 нед рекомендована контрольная колоноскопия с последующей консультацией врача-колопроктолога для решения вопроса дальнейшего лечения и наблюдения. В сроки после 8 нед в клинику обратилось 
8 пациентов с данными контрольной эндоскопии, на которой слизистая толстой кишки полностью восстановилась. Этим больным рекомендована контрольная колоноскопия через 1 год.

Результаты и их обсуждение. Во всех случаях отмечен быстрый гемостатический эффрект и улучшение качества жизни больных от проводимого комплексного лечения. На сроках после 8 нед во всех наблюдениях эрозии эпителизировались. На сроках от 1 года до 3 лет наблюдалось 6 пациентов - признаков болезни не обнаружено.

Таким образом, комплексное лечение больных с эрозивными толстокишечными кровотечениями, включающее в себя салофальк в гранулах и свечах, мукофальк, закофальк позволяет добиться быстрого гемостаза, нормализации стула.

В заключение следует сказать, что внедрение указанного комплексного лечения эрозивных толстокишечных кровотечений позволяет в короткие сроки остановить кровотечение, нормализовать стул и тем самым улучшить результаты лечения.

\section{ЛИТЕРАТУРА}

1. Минасян, А.М. Пути улучшения результатов лечения больных с толстокишечным кровотечением / А.М. Минасян, А.М. Симонян // Вопросы теоретической и клинической медицины. - 2012. - № 7. - С.218-222.

2. Штопель, А.Э. Массивные кровотечения при патологии толстой кишки / А.Э. Штопель, А.А. Захарченко // Акту- альные проблемы проктологии. - 2005. - С.234-237 (Волгоград).

3. Barnert, J. Management of lower gastrointestinal tract bleeding / J. Barnert, H. Messmann // Best. Pract. Res. Clin. Gastroenterol. - 2008. — № 22. - P.295-312.

4. Longstreth, G.F. Epidemiology and outcome of patients hospitalized with acute lower gastrointestinal hemorrhage: a population-based study / G.F. Longstreth // Am. J. Gastroenterol. — 2004. — № 92. — P.419—424.

\section{REFERENCES}

1. Minasyan, A.M. Puti uluchsheniya rezul'tatov lecheniya bol'nyh s tolstokishechnym krovotecheniem [Ways of improving the treatment results of patients with colonic bleeding] / A.M. Minasyan, A.M. Simonyan // Voprosy teoreticheskoi i klinicheskoi mediciny [Questions of theoretical and clinical medicine]. — 2012. — № 7. S.218-222.

2. Shtopel', A.E. Massivnye krovotecheniya pri patologii tolstoi kishki [Massive bleeding in the pathology of the colon] / A.E. Shtopel', A.A. Zaharchenko // Aktual'nye problemy proktologii [Actual problems of proctology]. 2005. - S.234-237 (Volgograd).

3. Barnert, J. Management of lower gastrointestinal tract bleeding / J. Barnert, H. Messmann // Best. Pract. Res. Clin. Gastroenterol. — 2008. — № 22. - P.295-312.

4. Longstreth, G.F. Epidemiology and outcome of patients hospitalized with acute lower gastrointestinal hemorrhage: a population-based study / G.F. Longstreth // Am. J. Gastroenterol. — 2004. — № 92. - P.419-424.

Принята 02.10.2014 


\title{
ОЦЕНКА ЭФФЕКТИВНОСТИ ГЕМОСТАТИЧЕСКОГО ДЕЙСТВИЯ ПРЕПАРАТА «ГЕМОБЛОК» ПРИ ПОЛОСТНЫХ И ЛАПАРОСКОПИЧЕСКИХ ВМЕШАТЕЛЬСТВАХ. МУЛЬТИЦЕНТРОВЫЕ КЛИНИЧЕСКИЕ ИССЛЕДОВАНИЯ
}

\author{
АЛЕКСАНДР ВЯЧЕСЛАВОВИЧ ПЛОТКИН, докт. меД. наук, профессор, директор Московского областного \\ научно-исследовательского института крови, Москва, Россия \\ ЕВГЕНИЙ ЖАНОВИЧ ПОКРОВСКИЙ, докт. мед. наук, доцент, зав. кафедрой госпитальной хирургии \\ ГБОУ ВПО ИвГМА Минздрава РосСИи, Иваново, Россия \\ ГАЛИНА ВЯЧЕСЛАВОВНА ВОРОНОВА, Зам. ГЛавНоГО врача По ЛечебНоЙ работе ОБУЗ «КинешемСКая ЦРБ», \\ врач-ЭндОсКопист, КИнешма, Россия \\ КСЕНИЯ АЛЕКСАНДРОВНА МЕНГЛЕТ, ВеДУЩИЙ НаУЧНЫЙ СотрУДнИк МосКОВСКОГО областНоГО \\ научно-исследовательского института крови, Москва, Россия
}

Реферат. Цель - обобщены результаты мультицентрового клинического исследования, которое было проведено в 4 медицинских центрах различных регионов Российской Федерации. Оно касалось оценки эффективности гемостатических свойств препарата «Гемоблок» при различных хирургических вмешательствах. Материал и методы. Всего было прооперировано 89 пациентов, при этом в 31 случае препарат апплицировался на кровоточащую поверхность в ходе видеолапароскопической операции посредством обильно смоченной в гемоблоке марлевой салфетки, вводимой через 5 мм тубус, в 35 случаях препарат наносился на раневую поверхность посредством смоченной марлевой салфетки при полостной хирургической операции, а в 23 случаях препарат вводился лапароскопически путем прицельной ирригации через катетер, вводимый через эзофагогастродуоденоскоп. Результаты. Показано, что при различных патологиях у пациентов фиксировался надежный гемостаз при всех типах операционного вмешательства. Таким образом, препарат «Гемоблок» показал себя высокоэффективным местным гемостатиком.

Ключевые слова: гемоблок, капиллярное кровотечение, паренхиматозное кровотечение, гемостатический препарат.

\section{THE EVALUATION OF THE EFFECTIVITY OF HEMOSTATIC ACTIVITY OF HAEMOBLOCK FOR LOCAL TOPICAL USE HAEMOBLOCK IN DIFFERENT SURGICAL SITUATIONS. MULTICENTER CLINICAL TRIALS}

\author{
ALEXSANDER V. PLOTKIN, M.D., Professor, Head of Moscow region scientific research institute, Moscow, Russia \\ EVGENIY ZH. POKROVSKIJ, M.D., assistant professor, Head of hospital surgery chair GBOU VPO IvGMA, Ivanovo, Russia \\ GALINA V. VORONOVA, deputy of head doctor of Hospital of Kineshma, Russia
}

KSENIA A. MENGLET, Moscow region scientific research institute, research officer, Moscow, Russia

\begin{abstract}
Aim. The trial refers to the evaluation of the effectivity of Haemoblock as a hemostatic aid solution for local topical use in different surgical situations. Material and methods. The trial included 89 patients. 31 patients were operated on with videolaparoscopic method with Haemoblock being delivered through $5 \mathrm{~mm}$ tubus on a soaked gauze wad on the wound surface. 35 patients were operated on using different methods of abdominal surgery while Haemoblock was delivered by a soaked gauze wad on the surface of the wound. 23 patients were operated on with the laparoscopic method of aimed irrigation of the hemostatic aid solution through ezophagogastroduodenoskope. Results. Haemoblock demonstrated reliable hemostasis in all groups of patients and proved to be highly efficient.
\end{abstract}

Key words: haemoblock, capillary hemorrhage, parenchymal hemorrhage, hemostatic.

роблема эфффективной интраоперационной

остановки кровотечения и снижения риска инфекционных осложнений в послеоперационном периоде является весьма актуальной, и в этой связи новый местный гемостатик гемоблок с бактерицидной функцией представляет значительный интерес.

Медицинское средство «Гемоблок» является местным гемостатиком и зарегистрировано в РФ как медицинское изделие. В его состав входит неполная серебряная соль полиакриловой кислоты, содержащая наночастицы серебра, это обусловливает выраженное бактерицидное и бактериостатическое действие гемоблока. Применяют препарат наружно при паренхиматозных и капиллярных кровотечениях. При этом смачивают стерильные ватные или марлевые тампоны и прикладывают к кроваточащей, предварительно осушенной поверхности раны. При больших раневых поверхностях используют препарат в виде спрея. Гемостатический эффеект достигается в течение 12 мин. 
Гемостатический эфффект достигается за счет образования гемоблоком сгустка с белками плазмы крови (главным образом, альбумином). Последние исследования, проведенные в лаборатории Московского областного НИИ крови, показали, что механизм действия гемоблока не зависит от концентрации белковых кровесвертывающих фракторов в плазме крови, но зависит, главным образом, от содержания альбумина.

На первом этапе действия препарата складывается полиакриловая матричная структура, содержащая молекулы альбумина в ячейках полиакриловой матрицы. Такая структура является первичной и во время ее существования невелико, поскольку полиакрилат-анион не устанавливает сильные связи с молекулами белка и удерживается лишь за счет слабых взаимодействий. Однако эта структура является первичным организатором устойчивой пленки.

На следующем этапе ионы серебра восстанавливаются молекулами альбумина, образуя устойчивый комплекс: полиакрилат-анионы образуют прочную связь с положительно заряженными молекулами белка. Такая структура упаковывается в несколько микрослоев, создавая прочную полиметакрилатную пленку на поверхности раны. При этом восстановленное металлическое серебро в комплексе с белками является мощным бактерицидным фрактором, что и обеспечивает отсутствие нагноений при использовании гемоблока. В дальнейшем поверхностная структура гемоблок - белок замещается фиибрином. А полиакрилатная матрица плазмолизуется в течение суток.

Цель настоящего исследования - оценка эффективности гемостатического действия препарата «Гемоблок» при полостных и лапароскопических вмешательствах.

Материал и методы. Для оценки эффективности местного гемостаза при использовании препарата «Гемоблок» было проведено мультицентровое исследование. В исследование были включены 89 пациентов, проходивших лечение в четырех лечебных учреждениях РФ

1. Клиника госпитальной хирургии ОБУЗ «Городская клиническая больница № 4» г. Иваново.

2. Хирургический центр НУЗ ЦКБ № 1 ОАО «РЖД», г. Москва.

3. Отделение эндоскопии ГБУЗ ОКБ № 3, г. Челябинск.

4. Отделение эндоскопии Центральной районной больницы, г. Кинешма, Ивановская область.

Пациенты были разбиты на 3 группы. Каждая группа характеризовалась методом доставки гемостатического средства «Гемоблок» на раневую поверхность.

1. 31 пациент получили оперативное лечение по поводу острого деструктивного холецистита. Операции выполнялась видеолапароскопически. Гемоблок наносился на кровоточащую поверхность обильно смоченной марлевой салфеткой, доставляемой к раневой поверхности через 5 мм тубус.

2. 35 пациентов с острой хирургической патологией органов брюшной полости, магистральных сосудов и костей скелета были прооперированы различными методами абдоминальной хирургии при полостных операциях. Гемоблок наносился на раневую поверхность обильно смоченной марлевой салфеткой на открытую раневую поверхность.

3. 23 пациента с различными хирургическими и онкологическими патологиями были прооперированы лапароскопическим методом. Гемоблок доставлялся к кровоточащей поверхности прицельной ирригацией через катетер, вводимый через эзофагогастродуоденоскоп.

\section{Ход исследования}

1. Клиника госпитальной хирургии ОБУз "Городская клиническая больница № 4» 2. Иваново, группа под руководством Е.Ж. Покровского, докт. мед. наук, доцента, зав. кафедрой госпитальной хирургчей ГБОУ ВПО ИвГМА МЗ России (Иваново).

Было проведено динамическое проспективное исследование 39 больных. Препарат был использован при дифффузных (капиллярных) кровотечениях из ткани печени у больных в ходе оперативного лечения острой хирургической патологии.

Среди непосредственных причин основную группу составили такие заболевания, как острый калькулезный деструктивный холецистит (79,5\%) и очаговые поражения печени (внутрипеченочные абсцессы - 7,7\%; метастатические поражения $12,8 \%)$

Оперативное лечение по поводу острого деструктивного холецистита выполняли в срочном порядке, во всех случаях использовали видеолапароскопическую холецистэктомию. В ходе оперативного пособия у этой группы больных частым явлением являлось диффузное кровотечение из ложа желчного пузыря. Кроме того, немаловажным аспектом применения гемоблока являлся и его антибактериальный эфффект, существенный при деструктивном холецистите. Как известно, дополнительная и чрезмерная коагуляция ложа желчного пузыря в ходе операции зачастую должного гемостатического эфффекта не дает. Создается дополнительная зона коагуляционного некроза, которая сама по себе в послеоперационном периоде может служить источником гипертермии и субстратом для гнойных процессов.

Объемные образования печени, диагностированные в ходе обследования или интраоперационно, в некоторых случаях требуют атипичных резекций печени, также сопровождающихся дифффузным кровотечением. В наших случаях при обширных гнойных процессах операцию выполняли с помощью аппаратa LigaShure, а биопсийный материал забирали традиционно. Необходимо отметить, что в проведенных наблюдениях даже применение LigaShure не всегда обеспечивает стабильный гемостаз на поверхности печени. Связано это, прежде всего, с особенностью самого аппарата, а именно: сближением браншзажима и исключением фррагментов поверхности с мелкими сосудами из зоны действия аппарата. Более подробно характер основного заболевания представлен в табл. 1.

У большинства обследованных больных диагностирована сопутствующая сердечно-сосудистая 
Характер основного заболевания исследуемых больных

\begin{tabular}{|c|c|c|}
\hline \multirow{2}{*}{ Основное заболевание } & \multicolumn{2}{|c|}{ Количество больных } \\
\hline & Абс. & $\%$ \\
\hline ЖКБ. Острый калькулезный флегмонозный холецистит & 11 & 28,2 \\
\hline ЖКБ. Острый калькулезный фрлегмонозный холецистит. Эмпиема желчного пузыря & 12 & 30,7 \\
\hline ЖКБ. Острый калькулезный гангренозный холецистит & 6 & 15,6 \\
\hline Острый флегмонозный бескаменный холецистит & 1 & 2,5 \\
\hline Острый гангренозный бескаменный холецистит & 1 & 2,5 \\
\hline Абсцесс печени & 3 & 7,7 \\
\hline Рак желчного пузыря с метастазами в печень & 1 & 2,5 \\
\hline Метастатическое поражение печени (рак слепой кишки, рак яичников) & 4 & 10,3 \\
\hline Bcero & 39 & 100 \\
\hline
\end{tabular}

патология: гипертоническая болезнь $(80,5 \%)$ и ишемическая болезнь $(75,4 \%)$ сердца. Среди лиц женского пола велика встречаемость хронической гинекологической патологии воспалительного генеза и миоматозного поражения матки (84,8\%), а у мужчин - доброкачественной гиперплазии предстательной железы (46,9\%). В целом структура сопутствующей патологии отражает уровень и характер заболеваемости населения обслуживаемой территории, где велик процент сахарного диабета, хронических заболеваний вен нижних конечностей (варикозного расширения вен, хронической веноз- ной недостаточности) и хронических заболеваний дыхательных путей (хронической обструктивной болезни легких, хронического бронхита, бронхиальной астмы).

Женщин было в 1,7 раза больше. Основную массу составили пациенты трудоспособного возраста. Большая часть наблюдений приходится на больных пожилого и старческого возраста - 33,6\%.

Методика применения препарата была следующей. При открытой операции средняя салфетка смачивалась в 25-50 мл раствора «Гемоблок», перед наложением этой салфетки на рану кратковременно

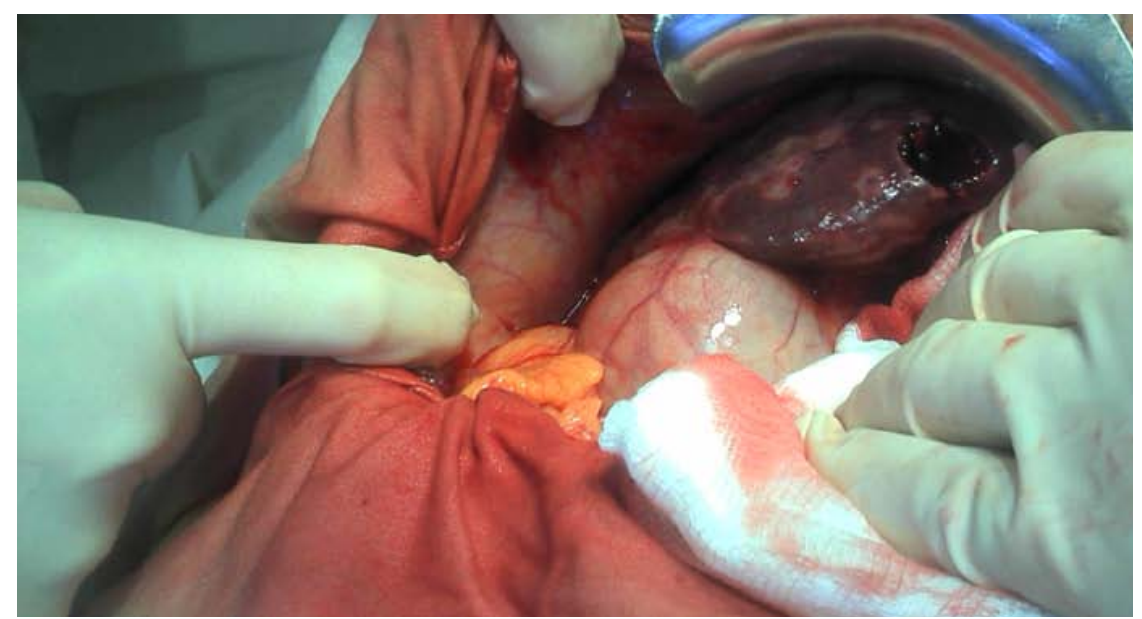

Рис. 1. Диффрузное кровотечение при биопсии печени

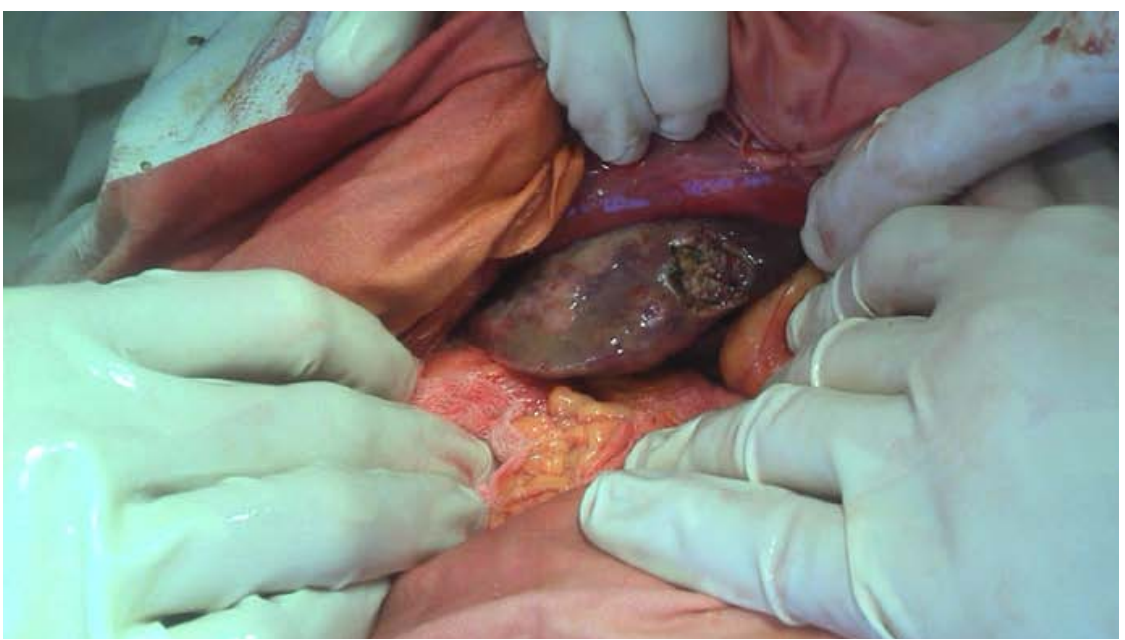

Рис. 2. Кровотечение остановлено препаратом «Гемоблок» 
накладывали сухую салфетку, после удаления которой сразу накладывали салфетку с препаратом. Экспозиция составляла 2-3 мин. Во всех случаях был достигнут стабильный гемостаз (рис. 1, 2).

\section{Клинические примеры}

Протокол (выписка) операции больной Б.

Операция 17.01.14. Резекция VI сегмента печени. Тампонирование подпеченочного пространства.

Ход операции. Разрезом Федорова в правом подреберье послойно вскрыта брюшная полость. Выпота нет. В шестом сегмента печени определяется деструктивный процесс в виде детрита (возможно опухолевого характера), других отсевов в печени нет. Учитывая локализацию и характер поражения, выполнена резекция шестого сегмента с применением аппарата LigaShure. Тампон с гемоблоком. Послойное ушивание лапаротомной раны, йод, повязка.

Препарат: фррагмент ткани печени с детритом на гистологию.

Диагноз после операции: абсцесс (опухолевый распад?) VI сегмента печени.

Протокол (выписка) операции больной M.

Операция 31.03.14. Энуклеация гигантской кисты левой доли печени. Дренирование и тампонирование брюшной полости.

Ход операции. Разрезом в правом подреберье с иссечением старого послеоперационного рубца и переходом на левое подреберье рассечена кожа и подкожная клетчатка. Гемостаз. Вскрытие брюшной полости. Ревизия. Спаечный процесс в подпеченочном пространстве и в месте операционного доступа, препятствующий полноценной ревизии. Грубой патологии не выявлено. Выделена правая и левая доля печени, желчный пузырь и внепеченочные желчные ходы. Тупым путем удалось отойти от холедоха и гепатикуса, правого и левого печеночного протока. Киста печени располагается в левой доле на границе с правой долей и фрагментом нормальной печеночной ткани по диафрагмальной поверхности слева. Размеры кисты около 12-14 см. Учитывая ранее выполненную операцию по вскрытию кисты, большие ее размеры, показано удаление кисты вместе с капсулой. С помощью LigaShure выполнена энуклеация образования, при этом не удалось избежать самопроизвольного вскрытия его с поступлением гноя со сладковатым запахом. Киста удалена в пределах здоровых тканей. Редкие узловые швы на ложе с привлечением большого сальника и тампоном с гемоблоком. Тампон над печенью, дренаж в подпеченочное пространство. Санация. Контроль гемостаза. Послойное ушивание раны до тампонов и дренажей, йод, повязка.

Препарат: киста левой доли печени размером около 12-14 см в диаметре, стенка ее около 2-3 мм. Полость содержит несколько дополнительных полостей, на гистологию.

Диагноз после операции: инфицированная многокамерная киста левой доли печени.

В ходе видеолапароскопической операции методика была несколько иной. Проводили орошение ложа желчного пузыря 5\% раствором хлоргексидина, жидкость собирали отсосом, затем в предварительно вложенный 5 мм тубус салфетку, пропитанную гемоблоком (20-25 мл), подводили к ложу желчного пузыря зажимом и удерживали там около 2-3 мин. Во всех случаях удавалось добиться стабильного гемостаза.

В результате применения препарата «Гемоблок» можно отметить, что рецидивов кровотечения отмечено не было. При этом можно подчеркнуть, что достигнуто некоторое снижение таких осложнений, как инфильтрат в области желчного пузыря, подпеченочный абсцесс и коагуляционная гипертермия.

2. Хирургический центр НУЗ ЦКБ № 1 ОАО РЖД, г. Москва, группа под руководством М.В. Лысенко, докт. мед. наук, профессора, заслуженного врача РФ.

Гемоблок использовали у 27 больных в возрасте от 30 до 76 лет. Из них 16 человек страдали онкологической патологией (распространенным раком), 11 - острой хирургической патологией со стороны органов брюшной полости, магистральных сосудов и костей скелета.

При клинических испытаниях в 23 случаях получили стойкий гемостатический эффрект, в 2 - peцидив кровотечения, потребовавший у 1 больного повторного хирургического вмешательства, и еще у 1 - повторного введения препарата с экспозицией 5 мин. В 2 случаях гемоблок оказался неэффективным: у 1 больного в септическом шоке на фроне хронического холангита, при низком и неустойчивом АД продолжалось кровотечение из спаек брюшной полости, остановлено пластинками «Тахокомб» и марлевыми тампонами. У 1 больного кровотечение из мочеточника продолжалось, несмотря на введение в мочеточник 10 мл гемоблока с экспозицией 5 мин, так как мочеточник сообщался с аневризмой аорты, что потребовало операции нефрэктомии, пластики аорты трансплантатом [1].

3. Отделение эндоскопии ГБУЗ ОКБ № 3, г. Челябинск, О.Ю. Ситникова, Е.А. Трясеногова, В.Ю. Подиивалов.

В современной эндоскопической практике достаточно широко представлены методики эндоскопической остановки и профилактики желудочно-кишечных кровотечений. К ним относятся электро- и аргоноплазменная коагуляция, инъекционная терапия, лигирование и клипирование. Все они показаны при наличии локального, конкретного источника кровотечения (эрозия, язва, артериовенозная фистула и т.д.).

К числу недостатков данных методик можно отнести высокую стоимость оборудования, затруднения при труднодоступной локализации источника кровотечения.

В повседневной эндоскопической практике все чаще встречаются случаи, при которых имеется достаточно большая площадь поражения в виде капиллярного, диффузного кровотечения - 1В тип кровотечения по Forrest, вследствие чего вышеуказанные методики эндоскопического гемостаза не показаны (геморрагическая гастропатия, химический ожог пищевода, желудка и т.д.) или когда источник кровотечения прикрыт сгустком крови - 11В тип кровотечения по Forrest.

Наиболее простым и доступным эндоскопическим методом воздействия на такие зоны кровоте- 
чений является орошение гемостатическими препаратами, при взаимодействии которых с кровью образуется кровяной сгусток, плотно фиксируемый к стенке органа. Этот метод эфффективен при продолжающемся капиллярном и остановившемся кровотечении.

В настоящее время в клинической практике появилось новое гемостатическое средство местного применения препарат «Гемоблок», имеющее неспецифический механизм воздействия - при взаимодействии с белками крови (главным образом, с альбуминами) образуется полимерный комплекс, останавливающий кровотечение.

Были оценены возможности применения данного препарата в эндоскопии при кровотечениях 1B и 11В типа по классификации Forrest.

С этой целью была выполнена ирригация данного препарата через катетер во время гастродуоденоскопии на зону кровотечения у 11 больных. Кровоточащую зону или кровяные сгустки орошали гемоблоком в количестве 20 мл.

Среди пациентов все были мужчины в возрасте от 46 до 77 лет. Характеристика источников и типов кровотечений, результатов применения гемоблока представлены в табл. 2.

При 11В типе кровотечений мы применяли препарат только при наличии свежих, рыхлых кровяных сгустков. При их орошении наблюдалось изменение окраски и уменьшение размеров сгустков за счет из сжатия.

Как видно из данных табл. 2, во всех случаях применения гемоблока рецидива кровотечения не было.

\section{Выводы:}

1. Методика эндоскопического использования препарата «Гемоблок» проста в выполнении, не требует специального оборудования.
2. Наличие кровотечения 1В или 11В типа является одним из показаний для ирригационной эндоскопической терапии препаратом «Гемоблок» [2].

4. Отделение эндоскопии Центральной районной больницы, 2. Кинешма, Ивановская область, группа под руководством Г.В. Вороновой, зам. главного врача по лечебной работе ОБУЗ «Кинешемская ЦРБ», врач-эндоскопист.

Была проведена оценка действия препарата «Гемоблок» в эндоскопии и сравнение его с гемостатическим препаратом «Капрофер». Проводилась прицельная ирригация препарата через катетер, который вводят через эзофагогастродуоденоскоп. Кровоточащее место орошали гемоблоком в количестве 30 мл. Эндоскопический гемостаз применялся у 24 больных при дифффузных, капиллярных кровотечениях и при наличии сгустка крови на источнике кровотечения.

В исследование включались пациенты мужского пола в возрасте от 44 до 77 лет. Характеристика источников и типов кровотечений, результаты применения гемоблока представлены в табл. 3.

При орошении препаратом «Гемоблок» наблюдалось уменьшение размеров сгустков и изменение окраски, а при применении препарата «Капрофер» увеличение размера сгустков. Как видно из данных табл. 3, во всех случаях применения гемоблока рецидива кровотечения не было.

Показано, что у всех пациентов 1-й группы (31 чел.) гемостаз наступил за 1-3 мин. Вторичных кровотечений и нагноений не зафиксировано.

У 31 пациента 2-й группы гемостаз наступил за 1-3 мин. Вторичных кровотечений не зафиксировано. У 2 пациентов 2-й группы рецидив кровотечения потребовал повторной экспозиции препарата, у 2 пациентов 2-й группы препарат оказался неэффективен.

Та блица 2

Результаты эндоскопического гемостаза

\begin{tabular}{|l|l|c|c|}
\hline Тип кровотечения & \multicolumn{1}{|c|}{ Диагноз } & Количество больных & Наличие рецидива кровотечения \\
\hline \multirow{4}{*}{ 1В } & Острая язва 12-перстной кишки & 2 & - \\
\cline { 2 - 4 } & Химический ожог пищевода & 1 & - \\
\hline \multirow{4}{*}{$11 \mathrm{~B}$} & Острая язва желудка & 1 & - \\
\cline { 2 - 4 } & Эрозивный эзофагит & - & - \\
\cline { 2 - 4 } & Химический ожог пищевода & 2 & - \\
\cline { 2 - 4 } & Синдром Маллори一Вейса & 1 & - \\
\cline { 2 - 4 } & Хроническая язва жлудка & 1 & - \\
\cline { 2 - 4 } & Острая язва 12-перстной кишки & 1 & - \\
\hline \multirow{2}{*}{ Итого } & 11 & - \\
\hline
\end{tabular}

Таблица 3

Результаты эндоскопического гемостаза

\begin{tabular}{|l|c|c|c|c|}
\hline \multicolumn{1}{|c|}{ Диагноз } & Капрофер & Наличие рецидива & Гемоблок & Наличие рецидива \\
\hline Острая язва 12-перстной кишки & 2 & - & 2 & - \\
\hline Острая язва желудка & 2 & - & 2 & - \\
\hline Химический ожог пищевода & 1 & - & 1 & - \\
\hline Эрозивный эзофагит & 2 & - & 2 & - \\
\hline Синдром Маллори-Вейса & 3 & 1 & 3 & - \\
\hline Рак желудка & 2 & 1 & 2 & - \\
\hline Итого & 12 & 2 & 12 & - \\
\hline
\end{tabular}


В 3-й группе надежный гемостаз с экспозицией до 2 мин наблюдался у всех 23 пациентов. Во всех случаях использования нагноения не возникали.

Выводы. Гемостатическое средство «Гемоблок» является эффрективным местным гемостатиком. Независимо от способа доставки на раневую поверхность и анамнеза пациента. При полостной операции препарат оказал действие в 95\% случаев, при лапароскопическом вмешательстве оказал действие в $100 \%$ случаев.

\section{ЛИТЕРАТУРА}

1. Пфрафр, В.Ф. Опыт клинического применения нового гемостатического средства «Гемоблок» в хирургической практике / В.Ф. Пфраф; под ред. В.Ф. Пфафр. - М., 2014. - $56 \mathrm{c}$.

2. Ситникова, О.Ю. Первый опыт использования препарата гемоблок в эндоскопии желудочно-кишечных кровотечений / О.Ю. Ситникова, Е.А. Трясеногова, В.Ю. Подшивалов // Актуальные вопросы эндоскопии: IV Всерос. науч.-практ. конф. с международным участием: тез. докл., Санкт-Петербург, Россия, 27-28 марта 2014. - СПб., 2014

\section{REFERENCES}

1. Pfaf, V.F. Opyt klinicheskogo primeneniya novogo gemostaticheskogo sredstva «Gemoblok» v hirurgicheskoi praktike / V.F. Pfaf; pod red. V.F. Pfaf. - M., 2014. $56 \mathrm{~s}$.

2. Sitnikova, O.Yu. Pervyi opyt ispol'zovaniya preparata gemoblok $v$ endoskopii zheludochno-kishechnyh krovotechenii / O.Yu. Sitnikova, E.A. Tryasenogova, V.Yu. Podshivalov // Aktual'nye voprosy endoskopii: IV Vseros. nauch.-prakt. konf. s mezhdunarodnym uchastiem: tez. dokl., Sankt-Peterburg, Rossiya, 2728 marta 2014. — SPb., 2014.

Принята 10.12.2014 


\title{
ХРОНИЧЕСКАЯ ОБСТРУКТИВНАЯ БОЛЕЗНЬ ЛЕГКИХ (ХОБЛ). ПЕРЕМЕНЫ КАК ПОВОД ДЛЯ ОБСУЖДЕНИЯ
}

АЛЕКСАНДР АНДРЕЕВИЧ ВИЗЕЛЬ, ДокТ. МеД. Наук, професСор, зав. кафеДрой фтиЗИопуЛьмонологИИ ГБОУ ВПО «Казанский государственный медицинский университет» Минздрава России, главный внештатный специалист-пульмонолог Минздрава Татарстана, Казань, Россия, e-mail: lordara@inbox.ru

ИРИНА ЮРЬЕВНА ВИЗЕЛЬ, канд. меД. наук, ассистент кафедры фтизиопульмонологии ГБОУ ВПО

«Казанский государственный медицинский университет» Минздрава России, Казань, Россия, e-mail: tatpulmo@mail.ru НАИЛЬ БАГАУВИЧ АМИРОВ, докт. мед. наук, профессор кафедры общей врачебной практики ГБОУ ВПО «Казанский государственный медицинский университет» Минздрава России, академик РАЕ, Казань, Россия, e-mail: namirov@mail.ru

Реферат. Цель исследования - анализ последних публикаций по проблеме хронической обструктивной болезни легких. Материал и методы. Проведен обзор публикаций последних лет, посвященных стандартизации методов диагностики, дифференциальной диагностики, разработке стандартов лечения хронической обструктивной болезни легких. Проанализирована распространенность хронической обструктивной болезни легких в различных странах мира с различными уровнями доходов населения. Осуществлен анализ существующих рекомендаций Европейского респираторного общества и точки соприкосновения или различия с российскими национальными рекомендациями. Проведен анализ предложенных новых вариантов классификации хронической обструктивной болезни легких. Приведены результаты собственных исследований. Уделено большое внимание подбору лекарственной терапии в зависимости от вариантов течения хронической обструктивной болезни легких в соответствии с GOLD-2014. Рассмотрены возможности фрармакотерапии как препаратами отдельных групп, так и в комбинации. Выводы. В настоящее время представление о ХОБЛ претерпевает постоянные изменения, состоящие в улучшении понимания болезни, совершенствовании классификации и лечения, основанном на оптимизации имеющихся средств и внедрения новых молекул и устройств доставки. Ключевые слова: хроническая обструктивная болезнь легких, классификация, диагностика, лечение.

\section{CHRONIC OBSTRUCTIVE PULMONARY DISEASE (COPD). CHANGES AS A CAUSE FOR DISCUSSION}

\author{
ALEXANDER A. VIZEL, M.D., Professor, Head of Department of phthisiopulmonology of SBEl HPE «Kazan State \\ Medical University» of Ministry of Health of Russia, chief freelance specialist pulmonologist Ministry of Health of Tatarstan, \\ Kazan, Russia, e-mail: lordara@inbox.ru \\ IRINA YU. VIZEL, Ph.D., assistant of professor of Department of phthisiopulmonology of SBEI HPE «Kazan State \\ Medical University» of Ministry of Health of Russia, Kazan, Russia, e-mail: tatpulmo@mail.ru \\ NAIL B. AMIROV, M.D., Professor of Department of general practice of SBEI HPE «Kazan State Medical University» \\ of Ministry of Health of Russian, academician of the RAE, Kazan, Russia, e-mail: namirov@mail.ru
}

\begin{abstract}
Aim. To analyze the recent publications on the problem of chronic obstructive pulmonary disease (COPD). Material and methods. A review of recent publications on the standardization of methods of diagnosis, differential diagnosis, and the development of standards of treatment of chronic obstructive pulmonary disease were performed. We analyzed the prevalence of chronic obstructive pulmonary disease in different countries with different levels of income; analyzed the current recommendations of the European Respiratory Society and the points of interests or differences with the Russian national guidelines. We reviewed the proposed new warrants classification of chronic obstructive pulmonary disease. The results of their own research are included in current article. Paid more attention to the selection of drug therapy, depending on the forms of COPD in accordance with GOLD-2014. We surveyed the possibilities of pharmacotherapy drugs as separate groups, and combinations. Conclusions. Currently, the doctrine of COPD undergoing continuous changes, including as better understanding of the disease, improving the classification and treatment, based on the optimization of existing facilities and the introduction of new molecules and delivery devices.

Key words: chronic obstructive pulmonary disease, classification, diagnosis and treatment.
\end{abstract}

X роническая обструктивная болезнь легких (ХОБЛ) - обычно предотвратимое и курабельное заболевание, характеризующееся постоянным ограничением воздушного потока, которое обычно прогрессирует и связано с хронически повышенной воспалительной реакцией дыхательных путей и легких в ответ на контакт с вредными частицами и газами. Обострения и сопутствующие заболевания способствуют более тяжелому течению болезни [1, 2].

В мировой клинической медицине постоянно происходят два процесса. С одной стороны, разрабатываются стандарты, протоколы, рекомендации, направленные на унификацию ведения заболевания, 
что обусловлено необходимостью упрощения подходов, ориентированных на врача общей практики, занимающегося сотнями разных болезней. Унификация обусловлена и необходимостью разработки критериев качества оказания медицинской помощи, решения спорных вопросов на отраслевом и правовом уровне. С другой стороны, уже третье столетие цитируется высказывание Я. Мудрова (1809) о том, что лечить следует больного, а не болезнь. В англоязычной литературе мы встречаем мнение сэра Вильяма Ослера (1880), который полагал, что хороший врач лечит болезнь, а превосходный - больного. Современное общество обозначило это направление как «персонифицированная медицина». Хроническая обструктивная болезнь легких (ХОБЛ) является наглядным примером этих процессов в медицине. Изначально прошла «кристаллизация» понятия ХОБЛ, идущего от хронической пневмонии через хронический астматический бронхит, хронический обструктивный бронхит, термин «хронические обструктивные болезни легких» - это термин, обобщающий группу болезней.

Трудно переоценить значимость создания глобальной инициативы GOLD, которая в течение последних 16 лет обобщает и систематизирует итоги изучения этого заболевания. Однако как GOLD, так и Кокрейновские метаанализы не являются юридическими документами, но создают основу для создания документов в каждой из стран мира - национальных клинических рекомендаций, или гайдлайнов. После четкого определения ХОБЛ как нозологии были определены ее первые два френотипа - эмфризематозный и бронхитический, что указывало на клиническую неоднородность заболевания. В настоящее время доказано существование таких фенотипов ХОБЛ, как «с частыми обострениями и эмфиземой», «с частыми обострениями и хроническим бронхитом», без обострений и фенотип сочетанного течения ХОБЛ и бронхиальной астмы (ACOS) [2].

Смертность от ХОБЛ неуклонно растет и, по данным ВОЗ на 2012 г., при анализе данных всех стран мира она делит 3-е и 4-е места с инфекциями нижних дыхательных путей после ишемической болезни сердца и инсульта. Среди стран с высоким достатком, к которым Всемирный банк и Международный банк реконструкции и развития относят Россию, ХОБЛ делит 5-е и 6-е места с инфекциями нижних дыхательных путей, а на 3-е и 4-е выходят рак трахеи, бронхов, легких и болезнь Альцгеймера. В странах с достатком выше среднего ХОБЛ как причина смерти занимает 3-е место, в странах с достатком ниже среднего - 4-е, а в странах с низким достатком ХОБЛ не входит в первую десятку причин смерти, поскольку там на первом месте стоят инфекции нижних дыхательных путей, за которым и следуют ВИЧ-инфекция, диарея, инсульт, ишемическая болезнь сердца, малярия и др. (данные сайта BO3 http://www.who.int/mediacentre/factsheets/fs310/ en/index.htm).

Отечественные клинические рекомендации по диагностике и лечению больных ХОБЛ основаны, прежде всего, на глобальной инициативе GOLD.
Рассматривая как основу этот документ, отечественные эксперты отличаются более сбалансированной позицией по ряду вопросов [3]. В свое время, когда комитет GOLD предложил стадию ХОБЛ 0, описывающую больных, имеющих высокий риск развития ХОБЛ, но не имеющих доказанной обструкции, в России положение принято не было. Вскоре и в глобальной инициативе нулевая стадия перестала существовать.

B 2011 г. научный комитет GOLD озвучил переход от I-IV стадий на буквенную аббревиатуру ABCD, представленную на рисунке в редакции 2014 г. [1, 2]. В новой системе левая ось $Y_{1}$ представляет собой оставшуюся неизменной спирографическую градацию состояния больных (термин «стадия» заменен на «степень тяжести»). При этом объединены степени I-II и III-IV, образуя два диапазона функциональных нарушений. Ось Х в этой системе оценок также имеет два диапазона, основанных на ответах валидизированных вопросников САТ и $\mathrm{mMRC}$ (рекомендовано одномоментное использование одного вопросника), образуя подгруппы больных с большим количеством жалоб и симптомов либо с малым их количеством.

С клинической точки зрения существование чисто функциональной классификации нозологической формы было далеко от совершенства. Так, пациенты с тяжелыми нарушениями внешнего дыхания иногда живут дольше, чем пациенты с меньшей степенью обструкции. Было доказано, что важным фактором риска смерти является частота обострений [4], а больные ХОБЛ с частыми обострениями образуют один из устойчивых фенотипов этого заболевания [5]. Понятие «много обострений» было определено как два и более обострений в течение года, либо наличие хотя бы одного обострения в году, потребовавшего госпитализации. Два диапазона обострений в системе $\mathrm{ABCD}$ образуют не ось третьего измерения $(Z)$, что логично с точки зрения математики, а вторую ось $Y_{2}$. Когда в 2011 г. была представлена эта четырехпольная таблица, сразу возник вопрос: как можно определить точку на плоскости, если она имеет одну координату $X$ и две координаты $Y_{1}$ и $Y_{2}$ ? Либо это две точки, либо такой точки не может быть. Но эксперты сразу дали ответ: из значений $Y_{1}$ и $Y_{2}$ выбираем худшую и этим определяем состояние пациента. Так родилась новая классификация, которая, однако, не была скопирована в Национальные клинические рекомендации по ХОБЛ. В отечественном документе прописаны все ключевые положения GOLD-2014 (степень обструкции, баллы вопросников, частота обострений, фенотип, коморбидность и т.д.), но включать в диагноз латинские буквы новой классификации пока не стали [3].

Для практического врача обновленный подход безусловно прогрессивен. В понимании пациента, наряду с факторами загрязнения вдыхаемого воздуха и следующими за ними обструктивными нарушениями функции внешнего дыхания, сделаны акценты на выраженности клинических проявлений болезни и значимости частоты и тяжести обострений. Однако системная реализация, интеграция этих фракторов требует дальнейшего совершенствования. 
Описана в Федеральных клинических рекомендациях

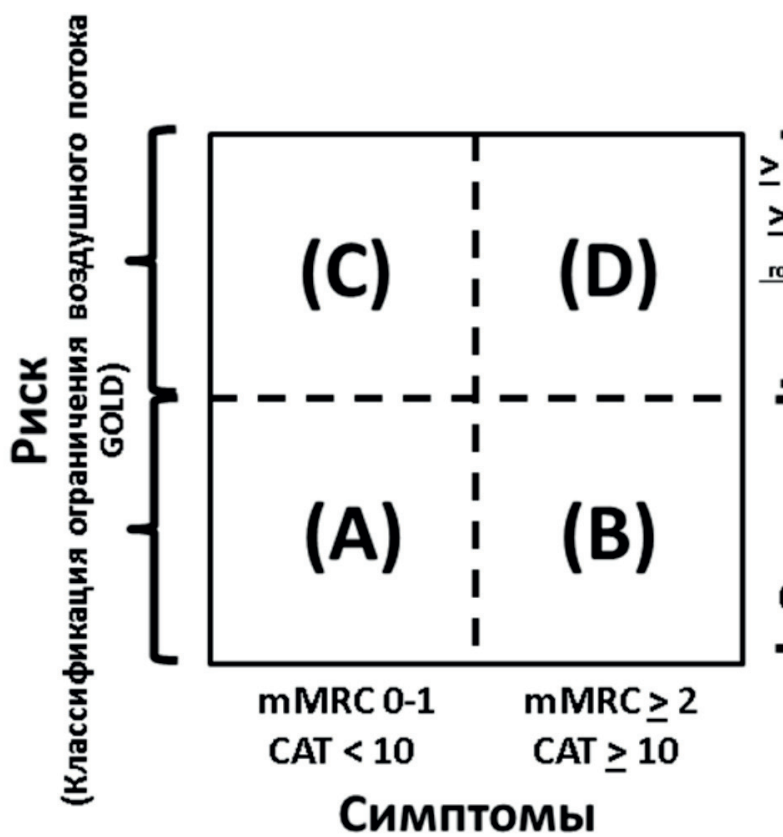

(опросник mMRC или шкала САT)
Пациент отнесен к одной из 4 категорий:

А. Симптомов меньше, низкий риск

В. Симптомов больше, низкий риск

С. Симптомов меньше,
высокий риск

D. Симптомов больше, высокий риск

Деление пациентов ХОБЛ на типы ABCD согласно пересмотру GOLD-2014

Прошло 3 года, и неумолимая математика с двумя осями Ү дала о себе знать. Группа европейских экспертов ретроспективно проанализировала больных ХОБЛ из клинических исследований ECLIPSE, COPDgene и COCOMICS и установила, что в этой отобранной для анализа когорте более всего было пациентов типа D, за которыми следовали A, B и C. В подгруппах с наиболее выраженными симптомами (B и D) оказалось более всего сопутствующих заболеваний. При длительном наблюдении пациенты из подгрупп A и D оставались в своих квадрантах, тогда как B и C чаще всего меняли свой квадрант со временем. Смертность спустя 3 года была самой низкой среди больных типа А и самой высокой - больных типа $D$, однако между подгруппами В и С различий не было [6].

Спустя год была опубликована работа из Великобритании, в которой были изучены больные ХОБЛ из реальной популяции общей врачебной практики (6283 пациента), и в соответствии с типами ABCD среди них более всего было больных типа А, за которыми следовали D, C и B (при минимальной разнице между двумя последними [7]. То есть между популяциями из реальной практики Великобритании и из трех клинических исследований [6] распределение больных ХОБЛ согласно критериям ABCD было прямо противоположным. Авторы сопоставили распределение больных ХОБЛ в выборке из общей практики по тяжести согласно градациям I-IV и ABCD и установили отсутствие параллелизма в данных. Более всего было больных, соответствующих
GOLD-II, а менее всего - GOLD-IV. Среди больныX с частыми обострениями ОФВ был менее $50 \%$ от должных значений только у $40 \%$ больных, тогда как среди больных с ОФВ $<50 \%$ от должных частые обострения встречались у $30 \%$ [7]. Работала система с двумя осями $\mathrm{Y}$, и в данной популяции худшие показатели давала частота обострений, а не данные спирометрии. Отсюда следует, что квартиль D неоднороден.

Анализируя сложившуюся ситуацию соавторы классификации GOLD ABCD C.Vogelmeier и J. Vestbo в редакционной статье Европейского респираторного журнала (ERJ) констатировали [8], что риск обострений и риск госпитализаций не имеют тесной корреляции; что частота госпитализаций в группе В в 2 раза больше, чем в A, а в группах B и D более высока частота цереброваскулярных болезней, депрессии, рака и диабета. Авторы задали вопрос: должны ли мы включать сопутствующие заболевания при оценке ХОБЛ? Коморбидность очень значима, но неизвестно, какие тесты необходимы для этого и какими должны быть изменения в терапии, связанные с коморбидностью в соответствии с новыми квартилями заболевания.

Однако и по оси X этой системы тоже существуют вопросы. За последние годы из всех вопросников только CAT и mMRC рекомендованы экспертами GOLD. Однако если для определения подгрупп c меньшей симптоматикой (А и С) пороговые значения $\mathrm{mMRC} \geq 1$ и $\mathrm{CAT} \geq 10$ примерно эквивалентны, то для 
определения подгрупп с выраженной симптоматикой результаты оказались различными. В одной и той же выборке больных порог $\geq 2$ по шкале вопросника $\mathrm{mMRC}$ преодолело меньшее число пациентов, чем порог $\geq 10$ вопросника САТ. Этот фракт установили английские исследователи, проанализировавшие 1817 случаев ХОБЛ [9].

Следующим объектом обсуждения становится определение обострения, данного экспертами GOLD, которое звучит как: «Это острое состояние, характеризующееся таким ухудшением респираторных симптомов у пациента, которое выходит за рамки ежедневных обычных колебаний и приводит к изменению применяемой терапии» (прим. - выделено авторами) [2]. На площадке Европейского респираторного конгресса (Барселона, 2013) в докладе John Hurst от имени группы по созданию ERS-ATS руководства по обострениям ХОБЛ было отмечено, что ухудшение респираторных симптомов и изменение применяемой терапии у больного ХОБЛ способны вызвать присоединившаяся пневмония, или пневмоторакс, или развитие опухоли легкого. Добавим, что и острые формы туберкулеза также усиливают одышку и требуют назначения лечения. В связи с этим комитет вынес на обсуждение новое определение: «Обострение ХОБЛ - это клинический диагноз исключения, устанавливаемый, когда больной ХОБЛ испытывает острое усиление респираторных симптомов (обычно одышку, кашель, увеличение количества и гнойности мокроты), у которого нет альтернативных конкретных причин для этого ухудшения, которое было обнаружено при клиническом обследовании и/или подтверждено тестированием. Ухудшение респираторных симптомов может или не может потребовать изменения в базовой терапии, а симптомы обычно разрешаются в течение от нескольких дней до нескольких недель».

Следующим позитивным моментом классификации ABCD стало расширение применения разных групп препаратов при разных типах ХОБЛ. Бронхолитики длительного действия теперь рекомендованы при всех стадиях ХОБЛ (таблица).

Таблица существенно облегчает работу практического врача, однако расстановка препаратов основана на предшествующих метаанализах и консенсусах экспертов, которые отметили, что на данный момент нет опубликованных исследований, в которых проведена оценка лечения, предложенная в этой таблице, и выразили надежду на то, что такие работы скоро появятся [8].

Перечень препаратов, применяемых при ХОБЛ, расширяется, и необходим опыт в реальной клинической практике для того, чтобы оценить их эфрфективность и безопасность. За последние 40 лет лечение бронхообструктивной патологии прошло путь от системной терапии адреналином, атропином, эуфриллином, преднизолоном до высокодисперсных селективных ингаляционных препаратов. В настоящее время системным стероидам отведено место только для терапии обострений ХОБЛ; и последняя редакция GOLD рекомендует применять внутрь 40 мг преднизолона не более 5 дней [2], в работах из США - 40-60 мг преднизона per os до 14 дней [10], в отечественных клинических рекомендациях 30-40 мг/сут преднизолона в течение 5-14 дней [3]. Теофиллин сохраняет свое значение как препарат третьей линии, т.е. когда иные виды лечения недостаточно эффрективны.

Более 30 лет в отечественной практической медицине сохраняет прочную позицию фиксированная комбинация двух бронхолитиков короткого действия - фенотерола и ипратропия бромида, существующих как в виде дозирующего баллончика, так и виде капель для небулайзера. Значимость этой комбинации не смогли снизить даже появившиеся недавно сходные по составу генерические препараты, эфффективность которых оказалась не ниже оригинала.

В течение последних 20 лет комбинации ИГКС и ДДБА, такие как будесонид/формотерол и флутиказон/сальметерол занимали прочное положение в лечении больных тяжелого и крайне тяжелого течения с частыми обострениями, спектр таких комбинаций расширялся как по способам доставки, так и по новым молекулам. С одной стороны, совершенствовалась доставка известных молекул - применение мелкодисперсного дозируемого аэрозоля беклометазона/фрормотерола, а с другой - появление комбинации того же формотерола с высоко-

Лечение ХОБЛ в соответствии с GOLD-2014

\begin{tabular}{|c|c|c|c|}
\hline \multirow{2}{*}{ Группа } & \multicolumn{3}{|c|}{ Препараты выбора } \\
\hline & Рекомендуемый первый выбор & Альтернативный выбор & Другое возможное лечение \\
\hline A & КДАХП или КДБА & $\begin{array}{l}\text { ДДАХП или ДДБА, } \\
\text { или КДБА+КДАХП }\end{array}$ & Теофиллин \\
\hline B & ДДАХП или ДДБА & ДДАХП +ДДБА & $\begin{array}{l}\text { КДБА и/или КДАХП; } \\
\text { теофиллин }\end{array}$ \\
\hline C & $\begin{array}{l}\text { ИГКС +ДДБА } \\
\text { или ДДАХП }\end{array}$ & $\begin{array}{l}\text { ДДАХП +ДДБА } \\
\text { или ДДАХП +ИФДЭ-4, } \\
\text { или ДДБА+ИФДЭ-4 }\end{array}$ & $\begin{array}{l}\text { КДБА и/или КДАХП; } \\
\text { теофиллин }\end{array}$ \\
\hline $\mathrm{D}$ & $\begin{array}{l}\text { ИГКС +ДДБА } \\
\text { и/или ДДАХП }\end{array}$ & $\begin{array}{l}\text { ИГКС+ДДБА+ДДАХП; } \\
\text { ИГКС+ДДБА+ИФДЭ-4; } \\
\text { ДДАХП+ДДБА; } \\
\text { ДДАХП+ИФДЭ-4 }\end{array}$ & $\begin{array}{l}\text { Карбоцистеин; } \\
\text { КДБА и/или КДАХП; } \\
\text { теофиллин }\end{array}$ \\
\hline
\end{tabular}

Примечание: КДАХП — короткодействующие холинолитики; КДБА - короткодействующие бета-2-агонисты; ДДАХП длительно действующие холинолитики; ДДБА - длительно действующие бета-2-агонисты; ИГКС - ингаляционные кортикостероиды; ИФДЭ-4 — ингибиторы фоссродиэстеразы 4 
аффринным ИГКС мометазоном, эфффект которого связан в внегеномными механизмами. Лидерство фрормотерола было связано с быстротой наступления эффректа и 12-часовой длительностью. Однако оптимизм от применения ИГКС при ХОБЛ несколько омрачается увеличением частоты развития пневмонии, на что указано как в GOLD пересмотра 2014 г., так и в отдельных публикациях, указывающих, что риск пневмонии удваивается, если больные получают фллутиказон [11]. В этом ключе также имеет место полемика. Так, риск развития пневмонии при лечении ХОБЛ ИГКС был зависимым от дозы, и в большинстве исследований будесонида в средней дозировке существенного роста случаев пневмонии отмечено не было [12].

Появление тиотропия бромида - первого 24часового избирательного холиноблокатора открыло новую эру в бронхолитической терапии, названную впоследствии «фармакологическим стентированием». Препарат быстро занял свою нишу, а с приходом ABCD-классификации ХОБЛ его применение стало приемлемым для всех типов заболевания. Логичным был и следующий шаг - тройная комбинация. Одновременное применение будесонида, формотерола и тиотропия оказалось значительно эффрективнее монотерапии и двойной терапии, особенно в отношении частоты обострений — ключевого показателя выживания [13]. Создана также комбинация фрормотерол/гликопирроний/будесонид. Однако пока в России препаратов с тремя составляющими зарегистрировано не было.

Следующим шагом в развитии бронхолитиков стало появление ДДБА с 24-часовым эффректом, первым из которых в нашей стране стал индакатерол. Его отличие от тиотропия состоит не только в другом фрармакологическом классе, но и в быстроте наступления эффректа. Памятуя широкое применение формотерола в разных формах доставки и комбинациях логично было предположить, что новые 12- и 24-часовые бронхолитики будут обладать именно этим свойством. Так и случилось. Очередной $\mathrm{M}_{3}$-холиноблокатор гликопирроний с 24-часовым эффректом имел скорость наступления эффректа, сходную с сальбутамолом. Наличие двух молекул - индакатерола и гликопиррония - c разными точками приложения, но с очень близкой фрармакодинамикой, фрармакокинетикой и уровнем безопасности, привело к созданию нового класса фриксированных комбинаций двух бронходилататоров с 24-часовой длительностью действия [14]. Таковыми стали индакатерол/гликопирроний и вилантерол/умеклидиний. В то же время появились 24-часовой тиотропий/олодатерол и 12-часовой аклидиний/фрормотерол [15].

Пересмотр позиций препаратов разных классов в лечении ХОБЛ стал вполне очевидным при появлении таких комбинаций (и памятуя о долгожительстве первых фриксированных комбинаций), что и произошло с приходом классификации ABCD. B таблице (имеющей место как в документах GOLD последних лет, так в национальных клинических рекомендациях) бронхолитики длительного действия занимают 7 ячеек, комбинация бронхолитиков длительного действия - 3 ячейки, а привычная ранее комбинация ИГКС+ДДБА - только 2 ячейки (в остальных случаях они комбинированы с третьим препаратом) [1, 2, 3].

Текущий момент лечения ХОБЛ характеризуется конкурентными работами по лечению ХОБЛ как ИГКС+ДДБА, так и ДДАХП+ДДБА. Показательна работа Н. Magnussen и соавт. [16], в которой ответ на этот вопрос дан через призму известных и применяемых препаратов: у больных ХОБЛ тяжелого течения, получавших совместно тиотропий и сальметерол, риск среднетяжелых и тяжелых обострений не зависел от того, получали пациенты ИГКС или нет. Недавно опубликованный Кокрейновский метаанализ показал, что преимущества применения ИГКС при ХОБЛ очевидны только у больных с ОФВ 1 менее $50 \%$ от должных, а их преимущества в виде монотерапии и комбинации с ДДБА по сравнению с ДДАХП и ДДБА были очевидными только первые 6 мес терапии, а через 12 мес становились незначимыми [17]. Работа, проведенная ранее в нашей клинике, показала, что отношение шансов (OR) улучшения ОФВ в течение первого года включения ИГКС в терапию ХОБЛ составило 3,75, а при последующем годичном наблюдении отношение шансов становилось меньше единицы - 0,81. При

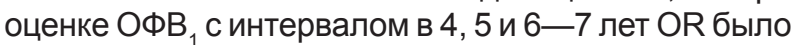
0,78, 0,88 и 1,10, т.е. увеличение ОФВ было маловероятно [18]. Это созвучно метаанализу 7 РККИ продолжительностью не менее 12 мес у больных со среднетяжелой и тяжелой ХОБЛ: было установлено, что в течение первых 6 мес после рандомизации применение ИГКС сопровождалось достоверным приростом ОФВ 1 по сравнению с плацебо; в период с 6-го по 36-й мес наблюдения различий в снижении ОФВ с плацебо не было [19]. В этом направлении можно ожидать много сравнительных работ, которые прольют свет на истину. Это связано еще и с тем, что появляются новые комбинации ИГКС+ДДБА, такие как индакатерол/мометазон и вилантерол/ фрлутиказонафуроат, которые смогут показать новые аспекты эфффективности и безопасности.

Особое место для системных и ингаляционных кортикостероидов отведено терапии больных ХОБЛ c фенотипом ACOS (сочетания ХОБЛ и бронхиальной астмы). Эффективность гормональной терапии в этом случае значительно выше, чем при ХОБЛ в «чистом виде», и особенно при сравнении ХОБЛ с бронхоэктазами и инфекционными обострениями, где показания к стероидной терапии ограничены [2].

В области альтернативных противовоспалительных препаратов в отечественную клиническую практику вошла лишь одна молекула для орального применения - ингибитор фосфодиэстразы-4 рофлумиласт, место которой нашлось в двух ячейках таблицы и только в сочетании с бронхолитиками длительного действия [3]. Перспективность изучения негормональной противовоспалительной терапии ХОБЛ подтверждает появление новых молекул, активных в отношении конкретных цитокинов, например бенрализумаба [20].

Антибактериальная терапия обострений ХОБЛ существенных изменений не претерпела - это не 
антисинегнойные бета-лактамы (чаще аминопенициллины), новые макролиды и фрторхинолоны с антипневмококковой активностью. В случаях тяжелых обострений с риском синегнойной инфекции рекомендованы ципро- и левофлоксацин, либо антисинегнойные бета-лактамы $[2,3]$.

В последние годы можно встретить работы, которые свидетельствуют о возможности применения антибиотиков в альтернативных режимах. В двойном слепом рандомизированном исследовании, проведенном в Нидерландах, применение азитромицина по 500 мг 3 раза в нед в течение 12 мес у больных ХОБЛ с частыми обострениями достоверно снижало частоту обострений в 2 раза [21]. Эфффективность макролидов и респираторных фрторхинолонов при обострениях ХОБЛ связывают также с их способностью разрушать бактериальные биопленки, образуемые Haemophilus influenzae и другими патогенами [22]. В то же время частое и длительное применение этих антибиотиков будет способствовать быстрому росту резистентности к ним.

Какие еще «подводные камни» мы встречаем при ближайшем рассмотрении современной классификации ХОБЛ? Как спирометрическая классифрикация ХОБЛ, так и ось $Y_{1}$ в классификации ABCD имеют фактор, вносящий неточность в этот параметр (ОФВ ${ }_{1} \%$ от должных значений), и затрудняют сравнение состояния пациента в динамике. Это расчет должных величин ОФВ 1 . Знаменатель дроби ОФВ фрактический/ОФВ должный может повлиять на определение типа ХОБЛ (степени тяжести). Ни международные, ни отечественные рекомендации не указывают, какую формулу расчета следует использовать, а результаты расчетов по разным формулам имеют весьма значимые различия [23]. Следовательно, если пациент обследован в двух разных центрах, где спирометры сконструированы на разные фрормулы расчета, то оценка параметров в динамике может быть необъективной.

В последние годы все чаще можно встретить сопоставление результатов контролируемых рандомизированных клинических исследований, имеющих строгие критерии включения и исключения больных ХОБЛ, и результаты ретроспективных или наблюдательных исследований в реальной клинической практике. Недавно было опубликовано валидизирующее международное исследование UNLOCK, в котором были сопоставлены больные ХОБЛ, вошедшие в шесть наиболее значимых рандомизированных клинических исследований, спонсированных фармацевтическими компаниями (ISOLDE, TRISTAN, TORCH, UPLIFT, ECLIPSE, POET-COPD), на которых основаны нынешние современные рекомендации, с популяцией больных первичной врачебной практики. Авторы отметили, что доля общеврачебной популяции больных ХОБЛ, соответствующих включению в эти исследования, варьировала от 17\% для РКИ TRISTAN до 42\% в РКИ ECLIPSE и UPLIFT [24].

В заключение хотелось бы сделать еще одну ремарку, которая позволяет объективно оценивать публикации, посвященные влиянию новых методов терапии на больных ХОБЛ. В 2008 г. М. Cazolla и соавт. разработали и валидизировали критерии, позволяющие говорить о клинической значимости изменений, вызванных лечением ХОБЛ. Очень важно понимать, что статистическая значимость не тождественна клинической. Так, прирост объема на 5 мл в 99 случаев из 100 дает высокодостоверный результат, но это никак не влияет ни на ощущения пациента, ни на прогноз заболевания. Приводим наиболее значимые критерии, предложенные этими авторами: снижение не менее чем на 4 балла общей шкалы вопросника госпиталя Святого Георгия (улучшение качества жизни); прирост ОФВ ${ }_{1}$ не менее чем на 100 мл, снижение частоты обострений ХОБЛ не менее чем на 1 обострение в течение года (и не менее чем на 22\%) [25].

Таким образом, в настоящее время содержание нормативных документов и рекомендаций претерпевает постоянные изменения, состоящие как в улучшении понимания ХОБЛ, совершенствовании классификации и лечения, оптимизации имеющихся средств и внедрения новых молекул и устройств доставки. Эти изменения отражают как пересмотры GOLD, так и обновленные версии клинических рекомендаций на сайте www.pulmonology.ru.

\section{ЛИТЕРАТУРА}

1. Глобальная стратегия диагностики, лечения и профилактики хронической обструктивной болезни легких (пересмотр 2011 г.): пер. с англ. / под ред. А.С. Белевского. - М.: Российское респираторное общество, 2012. - 80 с.: ил.

2. Global strategy for the diagnosis, management, and prevention of chronic obstructive pulmonary disease (GOLD). - Updated, 2014. - 80 p.

3. Чучалин, А.Г. Российское респираторное общество. Федеральные клинические рекомендации по диагностике и лечению хронической обструктивной болезни легких / А.Г. Чучалин, С.Н. Авдеев, З.Р. Айсанов [и др.] // Пульмонология. - 2014. - № 3. - С.15-54.

4. Soler-Cataluca, J.J. Impact of exacerbations on the clinical course of chronic obstructive pulmonary disease / J.J. Soler-Cataluca, M.A. Martinez-Garcia, P. Catalan Serra, P. Roman Sanchez // Rev. Clin. Esp. - 2011. Vol. 211, suppl. 2. - P.3-12.

5. Qureshi, H. Chronic obstructive pulmonary disease exacerbations: latest evidence and clinical implications / H. Qureshi, A. Sharafkhaneh, N.A. Hanania // Ther. Adv. Chronic. Dis. - 2014. - Vol. 5(5). - P.212-227.

6. Agusti, A. FAQs about the GOLD 2011 assessment proposal of COPD: a comparative analysis of four different cohorts / A. Agusti, S. Hurd, P. Jones [et al.] // Eur. Respir. J. - 2013. - Vol. 42(5). - P.1391-1401.

7. Haughney, J. The distribution of COPD in UK general practice using the new GOLD classification / J. Haughney, K. Gruffydd-Jones, J. Roberts [et al.] // Eur. Respir. J. 2014. - Vol. 43(4). - P.993-1002.

8. Vogelmeier, C. COPD assessment: I, II, III, IV and/or A, B, C, D / C. Vogelmeier, J. Vestbo // Eur. Respir. J. - 2014. Vol. 43(4). - P.949-950.

9. Jones, P.W. Comparisons of health status scores with MRC grades in COPD: implications for the GOLD 2011 classification / P.W. Jones, L. Adamek, G. Nadeau, N. Banik // Eur. Respir. J. - 2013. - Vol. 42(3). —P.647-654.

10. Sonstein, L. Improving adherence for management of acute exacerbation of chronic obstructive pulmonary disease / L. Sonstein, C. Clark, S. Seidensticker [et al.] // Am. J. Med. — 2014. — Vol. 127(11). — P.1097-1104 
11. Aaron, S.D. Management and prevention of exacerbations of COPD / S.D. Aaron // BMJ. - 2014. - Vol. 22, № 349. - P.5237.

12. Suissa, S. Inhaled corticosteroids in COPD and the risk of serious pneumonia / S. Suissa, V. Patenaude, F. Lapi, P. Ernst // Thorax. - 2013. - Vol. 68(11). P.1029-1036.

13. Welte, T. Efficacy and tolerability of budesonide/formoterol added to tiotropium in patients with chronic obstructive pulmonary disease / T. Welte, M. Miravitlles, P. Hernandez [et al.] // Am. J. Respir. Crit. Care Med. - 2009. Vol. 180(8). - P.741-750.

14. Frampton, J.E. QVA149 (indacaterol/glycopyrronium fixeddose combination): a review of its use in patients with chronic obstructive pulmonary disease / J.E. Frampton // Drugs. - 2014. - Vol. 74(4). - P.465-488.

15. Malerba, M. Differential pharmacology and clinical utility of emerging combination treatments in the management of COPD - role of umeclidinium/vilanterol / M. Malerba, J.B. Morjaria, A. Radaeli // Int. J. Chron. Obstruct. Pulmon. Dis. - 2014. - Vol. 9. - P.687-695.

16. Magnussen, $H$. WISDOM Investigators. Withdrawal of inhaled glucocorticoids and exacerbations of COPD / H. Magnussen, B. Disse, R. Rodriguez-Roisin [et al.] // N. Engl. J. Med. — 2014. - Vol. 371(14). - P.12851294.

17. Kew, K.M. Long-acting inhaled therapy (beta-agonists, anticholinergics and steroids) for COPD: a network metaanalysis / K.M. Kew, S. Dias, C.J. Cates // Cochrane Database Syst. Rev. - 2014. - Vol. 26, № 3. CD010844.

18. Stepanova, I.Yu. The results of long-term respiratory function monitoring of the patients with COPD / I.Yu. Stepanova, A.A. Vizel, E.A. Vizel // Europ. Resp. J. — 2003. — Vol. 22, suppl. 45. - Ref. № 2724. - P.425S.

19. Soriano, J.B. A pooled analysis of FEV1 decline in COPD patients randomized to inhaled corticosteroids or placebo / J.B. Soriano, D.D. Sin, X. Zhang [et al.] // Chest. 2007. - Vol. 131, № 3. - P.682-689.

20. Brightling, C.E. Benralizumab for chronic obstructive pulmonary disease and sputum eosinophilia: a randomised, double-blind, placebo-controlled, phase 2a study / C.E. Brightling, E.R. Bleecker, R.A. Panettieri [et al.] // Lancet Respir. Med. - 2014. - Sep. 5 (Epub ahead of print).

21. Uzun, S. Azithromycin maintenance treatment in patients with frequent exacerbations of chronic obstructive pulmonary disease (COLUMBUS): a randomised, doubleblind, placebo-controlled trial / S. Uzun, R.S. Djamin, J.A. Kluytmans [et al.] // Lancet Respir. Med. — 2014. Vol. 2(5). - P.361-368.

22. Uemura, Y. Comparison study of single and concurrent administrations of carbapenem, new quinolone, and macrolide against in vitro nontypeable Haemophilus influenzae mature biofilms / Y. Uemura, L. Qin, K. Gotoh [et al.] // J. Infect. Chemother. - 2013. — Vol. 19(5). P.902-908.

23. Pereira, C.A. Comparison between reference values for FVC, FEV1, and FEV1/FVC ratio in White adults in Brazil and those suggested by the Global Lung Function Initiative 2012 / C.A. Pereira, A.A. Duarte, A. Gimenez, M.R. Soares // J. Bras. Pneumol. — 2014. — Vol. 40(4). P.397-402.

24. Kruis, A.L. Primary care COPD patients compared with large pharmaceutically-sponsored COPD studies: an UNLOCK validation study / A.L. Kruis, B. Stellberg, R.C. Jones [et al.] // PLoS One. - 2014. — Vol. 9(3). P.e90145.

25. Cazzola, M. Outcomes for COPD pharmacological trials: from lung function to biomarkers; American Thoracic
Society; European Respiratory Society Task Force on outcomes of COPD / M. Cazzola, W. MacNee, F.J. Martinez [et al.] // Eur. Respir. J. — 2008. — Vol. 31(2). — P.416469.

\section{REFERENCES}

1. Global'naya strategiya diagnostiki, lecheniya i profilaktiki hronicheskoi obstruktivnoi bolezni legkih (peresmotr 2011 g.): per. s angl. / pod red. A.S. Belevskogo. - M.: Rossiiskoe respiratornoe obschestvo, 2012. - 80 s.: il.

2. Global strategy for the diagnosis, management, and prevention of chronic obstructive pulmonary disease (GOLD). - Updated, 2014. - 80 p.

3. Chuchalin, A.G. Rossiiskoe respiratornoe obschestvo. Federal'nye klinicheskie rekomendacii po diagnostike i lecheniyu hronicheskoi obstruktivnoi bolezni legkih / A.G. Chuchalin, S.N. Avdeev, Z.R. Aisanov [i dr.] // Pul'monologiya. - 2014. - № 3. - S.15-54.

4. Soler-Cataluca, J.J. Impact of exacerbations on the clinical course of chronic obstructive pulmonary disease / J.J. Soler-Cataluca, M.A. Martinez-Garcia, P. Catalan Serra, P. Roman Sanchez // Rev. Clin. Esp. - 2011. Vol. 211, suppl. 2. - P.3-12.

5. Qureshi, H. Chronic obstructive pulmonary disease exacerbations: latest evidence and clinical implications / H. Qureshi, A. Sharafkhaneh, N.A. Hanania // Ther. Adv. Chronic. Dis. - 2014. - Vol. 5(5). - P.212-227.

6. Agusti, A. FAQs about the GOLD 2011 assessment proposal of COPD: a comparative analysis of four different cohorts / A. Agusti, S. Hurd, P. Jones [et al.] // Eur. Respir. J. - 2013. - Vol. 42(5). - P.1391-1401.

7. Haughney, J. The distribution of COPD in UK general practice using the new GOLD classification / J. Haughney, K. Gruffydd-Jones, J. Roberts [et al.] // Eur. Respir. J. 2014. - Vol. 43(4). - P.993-1002.

8. Vogelmeier, C. COPD assessment: I, II, III, IV and/or A, B, C, D / C. Vogelmeier, J. Vestbo // Eur. Respir. J. — 2014. Vol. 43(4). - P.949-950.

9. Jones, P.W. Comparisons of health status scores with MRC grades in COPD: implications for the GOLD 2011 classification / P.W. Jones, L. Adamek, G. Nadeau, N. Banik // Eur. Respir. J. — 2013. - Vol. 42(3). -P.647-654.

10. Sonstein, $L$. Improving adherence for management of acute exacerbation of chronic obstructive pulmonary disease / L. Sonstein, C. Clark, S. Seidensticker [et al.] // Am. J. Med. - 2014. - Vol. 127(11). - P.1097-1104.

11. Aaron, S.D. Management and prevention of exacerbations of COPD / S.D. Aaron // BMJ. - 2014. - Vol. 22, № 349. - P.5237.

12. Suissa, S. Inhaled corticosteroids in COPD and the risk of serious pneumonia / S. Suissa, V. Patenaude, F. Lapi, P. Ernst // Thorax. - 2013. - Vol. 68(11). P.1029-1036.

13. Welte, T. Efficacy and tolerability of budesonide/formoterol added to tiotropium in patients with chronic obstructive pulmonary disease / T. Welte, M. Miravitlles, P. Hernandez [et al.] // Am. J. Respir. Crit. Care Med. - 2009. Vol. 180(8). - P.741-750.

14. Frampton, J.E. QVA149 (indacaterol/glycopyrronium fixeddose combination): a review of its use in patients with chronic obstructive pulmonary disease / J.E. Frampton // Drugs. - 2014. - Vol. 74(4). - P.465-488.

15. Malerba, M. Differential pharmacology and clinical utility of emerging combination treatments in the management of COPD - role of umeclidinium/vilanterol / M. Malerba, J.B. Morjaria, A. Radaeli // Int. J. Chron. Obstruct. Pulmon. Dis. - 2014. - Vol. 9. - P.687-695.

16. Magnussen, $H$. WISDOM Investigators. Withdrawal of inhaled glucocorticoids and exacerbations of COPD / 
H. Magnussen, B. Disse, R. Rodriguez-Roisin [et al.] // N. Engl. J. Med. - 2014. - Vol. 371(14). - P.12851294.

17. Kew, K.M. Long-acting inhaled therapy (beta-agonists, anticholinergics and steroids) for COPD: a network metaanalysis / K.M. Kew, S. Dias, C.J. Cates // Cochrane Database Syst. Rev. - 2014. - Vol. 26, № 3. CD010844

18. Stepanova, I.Yu. The results of long-term respiratory function monitoring of the patients with COPD / I.Yu. Stepanova, A.A. Vizel, E.A. Vizel // Europ. Resp. J. - 2003. - Vol. 22, suppl. 45. - Ref. № 2724. - P.425S.

19. Soriano, J.B. A pooled analysis of FEV1 decline in COPD patients randomized to inhaled corticosteroids or placebo / J.B. Soriano, D.D. Sin, X. Zhang [et al.] // Chest. 2007. - Vol. 131., № 3. - P.682-689.

20. Brightling, C.E. Benralizumab for chronic obstructive pulmonary disease and sputum eosinophilia: a randomised, double-blind, placebo-controlled, phase 2a study / C.E. Brightling, E.R. Bleecker, R.A. Panettieri [et al.] // Lancet Respir. Med. - 2014. - Sep. 5 (Epub ahead of print).

21. Uzun, S. Azithromycin maintenance treatment in patients with frequent exacerbations of chronic obstructive pulmonary disease (COLUMBUS): a randomised, doubleblind, placebo-controlled trial / S. Uzun, R.S. Djamin,
J.A. Kluytmans [et al.] // Lancet Respir. Med. — 2014. Vol. 2(5). - P.361-368.

22. Uemura, Y. Comparison study of single and concurrent administrations of carbapenem, new quinolone, and macrolide against in vitro nontypeable Haemophilus influenzae mature biofilms / Y. Uemura, L. Qin, K. Gotoh [et al.] // J. Infect. Chemother. - 2013. — Vol. 19(5). P.902-908.

23. Pereira, C.A. Comparison between reference values for FVC, FEV1, and FEV1/FVC ratio in White adults in Brazil and those suggested by the Global Lung Function Initiative 2012 / C.A. Pereira, A.A. Duarte, A. Gimenez, M.R. Soares // J. Bras. Pneumol. — 2014. — Vol. 40(4). P.397-402.

24. Kruis, A.L. Primary care COPD patients compared with large pharmaceutically-sponsored COPD studies: an UNLOCK validation study / A.L. Kruis, B. Stellberg, R.C. Jones [et al.] // PLoS One. - 2014. — Vol. 9(3). P.e90145.

25. Cazzola, M. Outcomes for COPD pharmacological trials: from lung function to biomarkers; American Thoracic Society; European Respiratory Society Task Force on outcomes of COPD / M. Cazzola, W. MacNee, F.J. Martinez [et al.] // Eur. Respir. J. - 2008. — Vol. 31(2). - P.416-469.

Принята 29.11.2014

๑ Г.С. Галяутдинов, М.А. Лонкин, 2015

УДК 616.89-008.454:616.12-008.46(048.8)

\section{КОГНИТИВНЫЕ НАРУШЕНИЯ ПРИ ХРОНИЧЕСКОЙ СЕРДЕЧНОЙ НЕДОСТАТОЧНОСТИ}

ГЕНШАТ САЛЯХУТДИНОВИЧ ГАЛЯУТДИНОВ, докт. мед. наук, профессор кафедры факультетской терапии и кардиологии ГБОУ ВПО «Казанский государственный медицинский университет» Минздрава России, Казань, Россия, тел. 8-960-048-37-63, e-mail: galgen077@mail.ru

МАРАТ АЛЕКСАНДРОВИЧ ЛОНКИН, аспирант кафедры факультетской терапии и кардиологии ГБОУ ВПО «Казанский государственный медицинский университет» Минздрава России, Казань, Россия, тел. 8-904-664-10-02, e-mail: pallaid@inbox.ru

Реферат. Цель исследования - изучение развития когнитивных нарушений при хронической сердечной недостаточности и возможных механизмов их развития. Материал и методы. Реферативный, аналитический и ретроспективный методы исследования зарубежной и российской литературы. Результаты и их обсуждение. В ходе анализа литературы выявлена достоверная взаимосвязь между течением хронической сердечной недостаточности и появлением когнитивных нарушений, что подтверждается многими патофизиологическими и биохимическими изменениями, индуцируемыми при развитии хронической сердечной недостаточности. Заключение и выводы. В настоящее время, учитывая выявленные факты, существенно должен измениться подход к тактике ведения пациентов с хронической сердечной недостаточностью и нужно решать проблему не только медицинскую, но и социальную, в результате чего целью лечения должно стать не только достижение необходимых и уже привычных показателей, но и улучшение качества жизни пациентов с хронической сердечной недостаточностью.

Ключевые слова: хроническая сердечная недостаточность, когнитивные нарушения.

\section{COGNITIVE IMPAIRMENT IN CHRONIC HEART FAILURE}

GENSHAT S. GALJAUTDINOV, M.D., Professor of Department of faculty therapy and cardiology of SBEI HPE «Kazan State Medical University» of Russian Ministry of Health, Kazan, Russia, tel. 8-960-048-37-63, e-mail: galgen077@mail.ru MARAT A. LONKIN, graduate student of Department of faculty therapy and cardiology of SBEI HPE «Kazan State Medical University» of Russian Ministry of Health, Kazan, Russia, tel. 8-904-664-10-02, e-mail: pallaid@inbox.ru

Abstract. Aim. To study cognitive impairment development in patients with chronic heart failure and possible mechanisms of its development. Material and methods. Current article is an analytical and retrospective review of foreign and Russian literature. Results and discussion. During the analysis of the literature we revealed significant correlation between the course of chronic heart failure and the development of cognitive impairment. That was confirmed by many pathophysiological and biochemical changes induced in the development of chronic heart failure. Summary and conclusions. At present time, given the fact-finding should significantly change the approach to tactics of patients with chronic heart failure, implying a problem not only medical but also social, resulting that the goal of treatment should be not only achieve required essential and the already routine levels, but also improving the quality of life of patients with chronic heart failure.

Key words: chronic heart failure, cognitive impairment. 
$\mathrm{H}^{2}$ а сегодняшний день одной из основных проблем среди сердечно-сосудистых заболеваний (СС3) является хроническая сердечная недостаточность $(\mathrm{XCH})$ - неизбежное следствие прогрессирования всех СС3 [1]. В то же время все большее значение придается роли психосоциальных фракторов в развитии, поддержании или даже прогрессировании многих болезней. В совокупности оба этих постулата требуют проведения глубокого анализа и выявления достоверного подтверждения влияния когнитивных нарушений $(\mathrm{KH})$ на течение хронической сердечной недостаточности.

В настоящее время многими авторами активно ведутся попытки верифицировать роль когнитивных нарушений при таких заболеваниях, как гипертоническая болезнь (ГБ) [2, 3], ишемическая болезнь сердца (ИБС) [4], мерцательная аритмия [5, 6], однако работ по хронической сердечной недостаточности сравнительно немного [4], что говорит о том, что взаимоотношения $\mathrm{XCH}$ и КН до сих пор до конца еще не изучены, в связи с чем мы в нашей работе и попытаемся это выяснить.

Когнитивные функции мозга - это способность понимать, познавать, изучать, осознавать, воспринимать и перерабатывать (запоминать, передавать, использовать) внешнюю информацию. Это функция центральной нервной системы - высшая нервная деятельность, без которой теряется личность человека.

К когнитивным (познавательным) функциям относят:

1. Внимание - способность поддерживать необходимый для познания уровень психической активности.

2. Восприятие - способность строить на основе информации, поступающей от органов чувств, целостные образы и представления.

3. Гнозис - способность опознавать формируемые образы и относить их к категориям разума.

4. Память - способность запечатлевать, сохранять и воспроизводить полученную информацию.

5. Интеллект - способность производить действия с усвоенной информацией (анализировать, сопоставлять, оценивать, обобщать, использовать для решения задач).

6. Речь - способность общаться с использованием символической знаковой системы (языка).

7. Праксис - способность фрормировать и включать в деятельность двигательные навыки, а также строить, заучивать и автоматизировать последовательность движений.

Bce перечисленные выше способности связаны с деятельностью головного мозга, а также зависят от общего состояния организма. Поэтому при нарушениях развития мозга, при его повреждениях, вызываемых воздействием заболевания или сильных эмоциональных состояний, качество когнитивных функций снижается по сравнению с исходными личными показателями человека и/или по сравнению со средними возрастными показателями для представителей его группы. Заметное снижение качества называют когнитивными расстройствами.
В зависимости от степени проявления КН выделяются разные уровни их тяжести.

Классификация когнитивных нарушений по тяжести [7]

1. Легкая степень. Снижение когнитивных нарушений по сравнению с более высоким преморбидным уровнем индивидуума формально остается в пределах среднестатистической возрастной нормы и отклоняется от нее незначительно. Обычно отражается в жалобах больного, но не обращает на себя внимания окружающих. Не вызывает затруднений в жизни.

2. Умеренная степень. Снижение когнитивных способностей, явно выходящее за пределы возрастной нормы. Отражается в жалобах индивидуума и обращает на себя внимание окружающих. Не приводит к существенным затруднениям в повседневной жизни, хотя может препятствовать наиболее сложным видам интеллектуальной активности.

3. Тяжелая степень. Снижение когнитивных способностей, которое приводит к существенным затруднениям в повседневной жизни, частичной или полной утрате независимости и самостоятельности.

Хроническая сердечная недостаточность - одно из наиболее частых осложнений СС3, во многом определяющее их течение и прогноз [8]. Особенно часто у пациентов с ХCH выявляют расстройства депрессивного характера [9, 10]. Именно они будучи проявлениями нарушений когнитивных функций наиболее часто встречаются в практике врача. За медицинской помощью обращается лишь около $20 \%$ пациентов с депрессией $[11,12]$, из них 60-90\% не к психиатрам, а к терапевтам, кардиологам, неврологам и врачам других специальностей [13, 14]. Это обусловлено как стигмой психических расстройств, так и частым проявлением депрессии с соматовегетативной симптоматикой. У кардиологических больных депрессия ассоциируется со снижением порога желудочковых аритмий, повышением риска внезапной остановки сердца и летальности [15-19]. Поэтому мы рассмотрим влияние нарушений когнитивных функций при ХСН с точки зрения влияния на $\mathrm{XCH}$ депрессии как одной из разновидностей когнитивных нарушений.

В настоящее время отмечается широкое распространение депрессивных расстройств и считается, что депрессия - это дополнительный фрактор снижения физической, психической и социальной активности больных ХCH [9]. Распространенность депрессии среди всех лиц, обращающихся в учреждения первичной медицинской помощи, составляет $5-10 \%$ [20]. Для сравнения в начале 60-х гг. она составляла 0,4-0,8\% [21]. Указанные тенденции отражают непрерывное увеличение количества депрессивных расстройств во всем мире. К 2020 г. по прогнозам Всемирной организации здравоохранения они предположительно займут 2-е место после сердечно-сосудистых заболеваний среди причин инвалидности и нетрудоспособности [22]. Депрессивное изменение настроения, наряду с искажением когнитивных процессов, сопровождается моторным торможением, снижением побуждений к 
деятельности, соматовегетативными дисфункциями. Депрессивная симптоматика негативно влияет на социальную адаптацию и качество жизни. Риск депрессий наиболее высок у пациентов с сердечнососудистыми заболеваниями, прежде всего с ИБС, инфарктом миокарда и сердечной недостаточностью. Распространенность депрессии среди больных с тяжелыми соматическими заболеваниями достигает 20—60\% [23, 24]. У пациентов с СС3 депрессия диагностируется более чем в половине наблюдений, причем самый высокий показатель отмечен при хронической сердечной недостаточности в $61 \%$ случаев [25]. Таким образом, пациенты с депрессивными нарушениями находятся в группе значительно повышенного риска развития сердечно-сосудистых заболеваний (ИБС, ГБ, ХСН и др.), и наоборот, у больных с сердечно-сосудистой патологией более высок риск развития расстройств афффективного спектра [26, 27, 28]. Сосуществование симптомов депрессии и сердечно-сосудистой патологии вызывает значительные затруднения в постановке диагноза. При этом врачи первичного звена, как правило, диагностируют и лечат только заболевания сердца [7]. Течение СС3 часто сопровождается физическими страданиями, когда пациенты вынуждены изменять привычный образ жизни, характеризующийся снижением качества жизни. Соматическое заболевание может повлечь за собой тяжелые фринансовые потери, угрозу утраты работы, инвалидизации или угрозу смерти. При этом пациенты испытывают утрату ощущения защищенности, необходимого для нормальной жизни, ощущения контроля над собственной жизнью, что приводит к чувству беспомощности [29]. По данным Фремингемского исследования, установлено, что частота распространения $\mathrm{XCH}$ увеличивается с возрастом, т.е. ХCH - частый «спутник» людей пожилого и старческого возрастов. ХСН ежегодно развивается у $1-3 \%$ лиц старше 60 лет и у примерно 10\% лиц старше 75 лет [30]. Увеличение доли лиц пожилого возраста считают одной из главных причин высокой распространенности ХСН в экономически развитых странах [31]. Увеличение среди населения людей пожилого и старческого возрастов привело к росту количества пациентов, страдающих депрессивными расстройствами (ДР) [32]. По результатам исследования КОМПАС, распространенность депрессий увеличивается с возрастом: вероятность наличия депрессии возрастает на 20\% каждые 10 лет; таким образом, ДР у пациентов 61-70 лет выявлены в 54\% случаев, причем у трети они носили выраженный характер. У пациентов старше 70 лет расстройства депрессивного спектра наблюдались в $61,7 \%$ случаев [33].

Современная модель патогенеза депрессии основана на особенностях нарушений фрункции гипоталамо-гипофизарно-надпочечниковой (ГГНС) [34], гипоталамо-гипофизарно-тиреоидной [35] и иммунной [36, 37] систем организма. К.сожалению, ни одна из представленных моделей не может претендовать на роль единственной гипотезы, полностью объясняющей природу депрессии. Вместе с тем доминирующей является детально обсуждаемая в литературе связь между депрессией и гиперактивностью ГГНС, симпатико-адреналовой и иммунной систем, а также подавлением активности серотонинергической системы [38]. При этом практически все исследователи едины в том, что нейроэндокринная составляющая депрессии регулируется именно этими системами.

Стресс, непосредственно связанный с развитием депрессии, сопровождается выбросом кортикотропин-релизинг-фактора (КРФ) из гипоталамуса [39]. КРФ воздействует на одноименные рецепторы передней доли гипофиза. Последняя отвечает выбросом адренокортикотропного гормона, который в свою очередь стимулирует высвобождение глюкокортикоидов (кортизола) из коры и катехоламинов (норадреналина) из мозгового слоя надпочечников. В норме эти процессы вскоре прекращаются, поскольку ГГНС регулируется по механизму отрицательной обратной связи. Известно, что в передней доле гипофиза локализуются глюкокортикоидные рецепторы, которые играют ключевую роль в торможении ГГНС и избыточной секреции глюкокортикоидов в условиях стресса [34]. Однако при депрессии этот механизм обратной связи, повидимому, нарушается [40]. Избыточная активация ГГНС приводит к уменьшению активности мозгового нейротрофического фактора и синтеза гормона роста с последующим развитием дислипидемии. Стресс приводит к ряду патологических изменений в гиппокампе, которые влекут за собой развитие депрессивных нарушений. В экспериментальном исследовании доказаны нейропротективные свойства тианептина, а также его способность восстанавливать объем гиппокампа за счет снижения выработки КРФ в гипоталамусе [41].

В последнее время депрессивные состояния связываются также с иммунными нарушениями и, следовательно, с повышенной предрасположенностью к инфекционным и неопластическим заболеваниям. Сравнительно недавно были получены клинические и экспериментальные данные, свидетельствующие о роли иммунитета, в первую очередь гиперсекреции провоспалительных цитокинов [фрактор некроза опухоли- $\alpha$ (ФНО- $)$, интерлейкин 6 (ИЛ-6) и др.] в манифестации и течении депрессии [42]. Также у больных с депрессией и ХСН отмечается снижение концентрации противовоспалительного ИЛ-10 и повышение концентрации растворимого медиатора апоптоза [37].

Интересным в этом плане представляется исследование Y. Young-Хu и соавт., продемонстрировавшее снижение риска развития депрессии и тревожного расстройства у больных ИБС на фоне применения статинов, обладающих противовоспалительным эфрфектом [43]. Одним из малоизученных механизмов взаимного влияния депрессии и ХCH является активация провоспалительных цитокинов. Негативные эфрфекты иммунного звена в патогенезе ХCH доказаны достаточно давно [44], но относительно недавно было показано, что при депрессии, как и при ХCH, значимо повышается уровень острофазных белков и провоспалительных цитокинов, что сопровождается повышением чувствительности 
миокарда к кардиотоксическому действию ФНО[45]. До сих пор не ясно, имеют ли антидепрессанты иммунорегуляторное действие, однако данное звено патогенеза представляет широкое поле для дальнейших исследований. ХCH сопровождается изменением привычного образа жизни, снижением ее качества, нередко потерей социального статуса. В процессе обычной повседневной деятельности пациент сталкивается со снижением способности функционирования, а в случае госпитализации - с необходимостью приспособиться к новым условиям, что нередко порождает чувство страха. ХCH может повлечь за собой тяжелые финансовые потери, угрозу утраты работы, инвалидизации или угрозу смерти. При этом пациенты испытывают утрату ощущения защищенности, необходимого для нормальной жизни, ощущения контроля над собственной жизнью, что приводит к чувству беспомощности [46]. Однако психологические особенности и психопатологические нарушения у больных $\mathrm{XCH}$ сравнительно недавно стали объектом пристального изучения. Повидимому, психосоциальные факторы, влияющие на течение и прогноз ИБС, таким же образом действуют при ХCH. Стресс и эмоциональное неблагополучие могут приводить к декомпенсации ХCH. Известно, что более чем в 50\% случаев госпитализации по поводу XCH предшествует эмоциональное напряжение [47]. Возможным механизмом этой связи является увеличение частоты сердечных сокращений и артериального давления и/или провоцирование ишемии у пациентов с XCH ишемического генеза с последующим снижением сократимости миокарда левого желудочка (ЛЖ). Предполагается, что фрункция лЖ может ухудшаться во время психологического стресса, и даже описана стресс-индуцированная сердечная недостаточность [48].

При исследовании пациентов с идиопатической кардиомиопатией обнаружено [49], что психологическая нагрузка может индуцировать нарушения диастолической функции ЛЖ. Кроме того, хорошо известно влияние психоэмоционального стресса на свертывающую систему крови [50, 51]. В частности, недавно было продемострировано неблагоприятное воздействие острого психологического стресса на показатели коагуляционного гемостаза [52]. В этих исследованиях были выявлены нарушения функции тромбоцитов (активация и повышенная их агрегация). Также было показано, что острый стресс приводит к гемоконцентрации за счет уменьшения объема плазмы [53]. Этот эфффект проясняет связь между вязкостью крови и сердечно-сосудистыми нарушениями при депрессии [54]. Таким образом, прямое патофизиологическое воздействие депрессии на сердечно-сосудистую систему приводит к развитию опасных для жизни клинических проявлений ХCH. Активация указанных выше нейроэндокринных систем приводит к гиперкортизолемии, дислипидемии, гиперкоагуляции, аритмиям и нарушению функции эндотелия сосудов.

Представленные выше патогенетические механизмы депрессии свидетельствуют о явной близости некоторых патофизиологических процессов ее формирования и развития таких ССЗ, как ИБС, ГБ и ХCH. Более того, недавно были обнаружены об- щие генетические механизмы, предопределяющие развитие депрессии и основных ССЗ. Так, стало известно, что в основе развития депрессии, ГБ и ИБС наряду с неблагоприятным воздействием факторов внешней среды лежат и общие генетические предпосылки. В частности, было установлено, что в развитии каждой их этих нозологических форм принимают участие одни и те же гены, отвечающие одновременно за развитие депрессии, ГБ и ИБС. Иными словами, развитие депрессии и основных CC3, приводящих к развитию $\mathrm{XCH}$, в значительной мере детерминировано общими наследственными фракторами [55]. В свете вышеизложенного становится понятным, почему полиморфизм гена ангиотензинпревращающего фермента (АПФ), являющегося одним из важных звеньев формирования $\mathrm{XCH}$, ассоциируется не только с активностью АПФ, но и с гиперкотизолемией, являющейся важным звеном в нейроэндокринной составляющей депрессии и, как следствие, развитием собственно аффективного расстройства [56]. При этом главный эффеектор в ренин-ангиотензин-альдостероновом механизме, лежащем в основе развития ХCH и ГБ, обладает прямым стимулирующим действием на секрецию КРФ, являющегося, в свою очередь, ведущим пусковым звеном гипоталамо-гипофизарно-надпочечниковой оси, доминирующей в формировании депрессии [57]. И наконец, избыточная продукция корой надпочечников альдостерона, играющего важную патофизиологическую роль в становлении ГБ, ИБС и ХСН, является не менее характерной особенностью депрессии, своего рода ее визитной карточкой, поскольку у пациентов с депрессией даже без сердечно-сосудистой патологии значительно повышен уровень этого минералокортикоида. Это позволило Н. Murck и соавт. назвать гиперальдостеронизм маркером депрессии [58].

Таким образом, можно заключить, что в основе развития $\mathrm{XCH}$ и депрессии лежат близкие по механизмам патофизиологические процессы, что позволяет предполагать наличие возможной взаимосвязи между этими состояниями и их взаимном потенцирующем воздействии. Более того, в последних исследованиях показано, что иАПФ, являющиеся ключевым классом медикаментов в лечении $\mathrm{XCH}$, могут обладать антидепрессивным и противотревожным действием [59], что косвенно подтверждает общность патогенетических механизмов, лежащих в основе $\mathrm{XCH}$ и депрессии.

У больных ХСН при наличии выраженных депрессивных нарушений значительно повышается риск повторных госпитализаций и смертельных исходов. В проспективном исследовании J. Junger и соавт. [60] было обнаружено, что депрессия является фактором риска (ФР) смерти независимо от функционального класса ХCH, фракции выброса ЛЖ и пикового потребления кислорода. Риск смерти у больных с высоким баллом по шкале HADS-D (выше медианы) к концу 30-го мес составил 8,2 [доверительный интервал (ДИ) 2,62-25,84]. Подобные результаты были получены и в другом проспективном исследовании [61]. Относительный риск (ОР) комбинированной конечной точки (смерть или трансплантация сердца) у 
больных с депрессией после коррекции по демографическим и клиническим параметрам составил 2,41 (ДИ 1,24-4,68). Кроме того, пациенты с депрессией чаще посещали кардиолога и их чаще госпитализировали. В исследованиях G.L. Clary и соавт. [62] не только подтверждено существование достоверной связи между депрессией и высокой смертностью от декомпенсации, но показано также, что у больных ХCH с сопутствующей депрессией при неэффективной терапии антидепрессантами показатели смертности были значимо выше, чем у этой же категории больных при эфрфективном лечении психотропными средствами. В другом исследовании показано, что наличие депрессии в анамнезе повышает риск комбинированной точки (смерть и сердечно-легочная реанимация) в 3,3 раза после коррекции по другим ФР при госпитализации в блок интенсивной терапии по поводу декомпенсации ХCH [63].

Значительное влияние большого депрессивного расстройства на смертность и частоту повторных госпитализаций у больных XCH показано также и в других исследованиях. Так, смертность у этой категории больных достигает 7,9\% в течение 3 мес и 16,2\% за 1 год. Пациенты с депрессией госпитализируются или умирают в 2 раза чаще, чем пациенты без таковой. Причем негативное влияние депрессии на выживаемость и частоту госпитализаций сохраняется даже при учете таких традиционных ФР, как возраст, функциональный класс XCH и фракция выброса левого желудочка [64]. Таким образом, большое депрессивное расстройство является независимым фрактором риска, повышающим смертность и частоту госпитализаций при ХCH [19].

Депрессия негативно сказывается не только на прогнозе $\mathrm{XCH}$, но и на ее клиническом течении [65]. При наличии аффективного расстройства усиливается усталость, снижается качество жизни, включая фризическую и эмоциональную составляющие, нарушается социальная поддержка и в целом поведение, направленное на преодоление болезни (coping behavior) [66, 67]. Кроме того, показано, что пациентам с депрессией реже назначаются $\beta$-адреноблокаторы, которые доказано увеличивают выживаемость больных ХCH [68]. Рядом авторов продемонстрировано не только влияние депрессии на смертность, но и ухудшение функционального статуса и качества жизни, пропорциональное количеству и выраженности депрессивных симптомов [69, 70]. В уникальном по длительности 6-летнем наблюдении у 119 стабильных амбулаторных больных с клинически выраженной ХCH выявлено повышение смертности в 1,05 раза при увеличении показателей на 1 балл по шкале самооценки депрессии Цунга [71]. У больных с выраженной депрессией по данным опросника риск смерти в течение 6 лет был в 2,5 раза выше, чем у больных без депрессии, даже после коррекции по таким факторам, как пол, возраст и уровень предсердного натрийуретического пептида. Кроме того, необходимо отметить, что наличие $\mathrm{XCH}$ у пожилых пациентов повышает риск суицида по сравнению со здоровыми пациентами того же возраста (ОР 1,73; 95\% ДИ 1,33-2,24). Особенно этот риск увеличивается при сочетании ХCH с депрессией (OР 6,44; 95\% ДИ 5,45-7,61) [72].

В настоящее время клиницистам предоставлены большие возможности выбора методов терапии депрессивных расстройств, а также их сочетаний - психофармакотерапия антидепрессантами с разными механизмами действия и различные формы психотерапии, таким образом есть много возможностей повлиять на развитие $\mathrm{XCH}$, уделяя внимание лечению когнитивных нарушений, однако на сегодняшний день достоверно мало данных о влиянии препаратов, направленных на лечение $\mathrm{XCH}$, на когнитивные функции, что еще предстоит исследовать.

Обобщая весь вышеизложенный материал, можно достоверно подтвердить существование патофизиологических и биохимических основ развития КН при ХСН. Учитывая это, практикующим врачам, работающим в медицинских организациях всех форм собственности, при столкновении с пациентом, страдающим ХCH, следует помнить о психоэмоциональной составляющей этой патологии.

\section{ЛИТЕРАТУРА}

1. Беленков, Ю.Н. Сердечно-сосудистый континуум / Ю.Н. Беленков, В.Ю. Мареев // Сердечная недостаточность. - 2002. - № 11. - С.7-11.

2. Остроумова, О.Д. Артериальная гипертония и когнитивные функции / О.Д. Остроумова // Эффеективная фармакотерапия. — 2013. — № 16. - С.16-22.

3. Крюков, Н.Н. Возможности коррекции когнитивных нарушений при гипертонической болезни и пароксизмальной фрибрилляции предсердий / Н.Н. Крюков, Е.В. Портнова // Российский медико-биологический вестник им. академика И.П. Павлова. - 2013. № 1. - C.88-93.

4. Лазарева, Е.Ю. Некоторые психологические характеристики пациентов с кардиальной патологией / Е.Ю. Лазарева, Е.Л. Николаев // Прикладные информационные аспекты медицины. - 2014. - Т. 17, № 1. - C.87-93.

5. Деревина, Е.С. Когнитивные нарушения при фрибрилляции предсердий на фоне сердечно-сосудистых нарушений / Е.С. Деревина, Н.С. Акимова, Т.В. Мартынович [и др.] // Анналы аритмологии. - 2013. - Т. 10, № 2. - C.87-94.

6. Ануфриева, Т.В. Особенности когнитивного статуса больных с пароксизмальной формой фрибрилляции предсердий / Т.В. Ануфриева, С.Л. Постникова, В.А. Ануфриева [и др.] // Лечебное дело. - 2014. № 1. - C.55-62.

7. Яхно, Н.Н. Когнитивные расстройства в неврологической клинике / Н.Н. Яхно // Неврологический журнал. 2006. — № 11, прил. 1. - С.4-12.

8. Смулевич, А.Б. Депрессии при соматических и психических заболеваниях / А.Б. Смулевич. - М., 2003. $423 \mathrm{c}$.

9. Погосова, Г.В. Депрессия: новый фактор риска ИБС и предиктор коронарной смерти / Г.В. Погосова // Кардиология. - 2002. — № 4. - С.86-90.

10. Ресина, И.А. Выявление состояний депрессии и тревоги, качество жизни у больных хронической сердечной недостаточностью / И.А. Ресина // Актуальные вопросы военной и практической медицины: сб. тр. II науч.практ. конф. врачей Приволжско-Уральского военного округа. - Оренбург, 2001. - С.220-223. 
11. Cross-National Collaborative Group. The changing rate of major depression. Cross-national comparisons (review) // JAMA. — 1992. — № 268. - P.3098-3105.

12. Мосолов, С.Н. Актуальные вопросы фрармакотерапии депрессий. Новые достижения в терапии психических заболеваний / С.Н. Мосолов, Е.Г. Костюкова. - М.: Изд-во БИНОМ, 2002. - С.211-232.

13. Costa-e-Silva, J.A. Facing depression. Editorial / J.A. Costae-Silva // WPA Teaching Bulletin on Depression. 1993. — № 1. - P.11.

14. Lecrubier, Y. Depression in medical practice/Y. Lecrubier // WPA Teaching Bulletin on Depression. - 1993. T. 1. - P.1-2.

15. Dunham, N.C. Functional status, symptoms of depression, and the outcomes of hospitalization in community-dwelling elderly patients / N.C. Dunham, M.A. Sager // Archives of Family Medicine. — 1994. - № 3. - P.676-681.

16. Jaffe, A. Minor depression and functional impairment / A. Jaffe, J. Froom, N. Galambos // Archives of Family Medicine. - 1994. — № 3. - P.1081-1086.

17. Empana, J.P. Clinical depression and risk of out-of-hospital cardiac arrest / J.P. Empana, X. Jouven, R.N. Lemaitre [et al.] // Archives of Internal Medicine. - 2006. № 166. - P.195-200.

18. Kessler, R.C. Lifetime and 12-month prevalence of DSMIII-R psychiatric disorders in the United States: results from the National Comorbidity Survey / R.C. Kessler, K.A. McGonagle, S. Zhao [et al.] // Archives of General Psychiatry. - 1994. — № 51. - P.8-19.

19. Jiang, $W$. Relationship of depression to increased risk of mortality and rehospitalization in patients with congestive heart failure / W. Jiang, J. Alexander, E. Christopher [et al.] // Archives of Internal Medicine. - 2001. — № 161. P.1849-1856.

20. Ватутин, Н.Т. Кардиология / Н.Т. Ватутин. - Донецк: Изд-во Каштан, 2008. - 446 с.

21. Katon, W. Epidemiology of depression in primary care / W. Katon, H. Schulberg // General Hospital Psychiatry. 1992. — № 14. - P.237-247.

22. Ustan, T.B. New classification for mental disorders with management guidelines for use in primary care $/$ T.B. Ustan, D. Goldberg, J. Cooper [et al.] // British Journal of General Practice. — 1995. — № 45. - P.211-215.

23. Carney, R.M. Depression and coronary heart disease: a review for cardiologists / R.M. Carney, K.E. Freeland, Y.I. Sheline // Clinical Cardioljgy. — 1997. — № 20. — P.196-200.

24. Cunningham, L.A. Depression in the medically ill: Choosing an antidepressant / L.A. Cunningham // Journal of Clinical Psychiatry. — 1994. — № 55. - P.90-100.

25. Чазов, Е.И. Клинико-эпидемиологическая программа изучения депрессии в кардиологической практике; у больных артериальной гипертонией и ишемической болезнью сердца (координата) / Е.И. Чазов, Р.Г. Оганов, Г.В. Погосова [и др.] // Кардиология. — 2005. № 11. - C.4-11.

26. Оганов, Р.Г. Распространенность депрессии в общей практике: масштабы проблемы / Р.Г. Оганов // Депрессия в кардиологии: больше, чем фактор риска: материалы симп. III Рос. нац. конгр. кардиологов. - М., 2003. - C.1-4

27. Diagnostic and statistical manual of mental disorders. $4^{\text {th }}$ ed. - DSMIV. - Washington, D.C.: American Psychiatric Association. — 1994. - P.511-518.

28. Larson, S.L. Depressive disorder, Dysthymia, and Risk of Stroke / S.L. Larson, P.L. Owens, D. Ford. // Stroke. 2001. — № 32. - P.19-79.

29. Barsky, A.J. Palpitations, cardiac awareness, and panic disorder / A.J. Barsky // American Journal of Medicine. 1992. — № 92. - P.315-345.
30. Crum, R.M. Depressive symptoms among general medical patients: prevalence and one-year outcome / R.M. Crum, L. Cooper-Patrick, D.E. Ford // Psychosomatic Medicine. - 1994. — № 56. - P.109-117.

31. Васюк, Ю.А. Депрессии при хронической сердечной недостаточности ишемического генеза / Ю.А. Васюк, Т.В. Довженко, Е.Л. Школьник // Сердечная недостаточность. - 2004. - № 5(3). - С.140-146.

32. Вейн, А.М. Депрессия в неврологической практике / А.М. Вейн, Т.Г. Вознесенская, В.Л. Голубев [и др.]. - М.: МИА, 2002. - $155 \mathrm{c}$.

33. Дамулин, И.В. Болезнь Альцгеймера и сосудистая деменция / И.В. Дамулин; под ред. Н.Н. Яхно. - М., 2002. $-85 \mathrm{c}$

34. Оганов, Р.Г. Депрессивные расстройства в общемедицинской практике по данным исследования КОМПАС: взгляд кардиолога / Р.Г. Оганов // Кардиология. 2005. — № 8. - C.37-43.

35. Plotsky, P.M. Psychoneuroendocrinology of depression. Hypothalamic-pituitary-adrenal axis / P.M. Plotsky, M.J. Owens, C.B. Nemeroff // Psychiatric Clinics of North America. - 1998. — № 21(2). - P.293-307.

36. Jackson, I.M. The thyroid axis and depression / I.M. Jackson // Thyroid. — 1998. — № 8. - P.951-956.

37. Maes, $M$. The immunoregulatory effects of antidepressants / M. Maes // Human Psychopharmacology. - 2001. № 16(1). - P.95-103.

38. Veith, R.C. Sympathetic nervous system activity in major depression. Basal and desipramine-induced alterations in plasma nor epinephrine kinetics / R.C. Veith // Archives of General Psychiatry. — 1994. — № 51(5). — P.411— 422.

39. Сыркин, А.Л. Пациенты со стенокардией, резистентной к монотерапии антиангинальными препаратами / А.Л. Сыркин // Consilium medicum. Экстравыпуск. 2003. - C.5-7.

40. Jacobson, L. The role of the hippocampus in feedback regulation of the hypothalamic-pituitary-adrenocortical axis / L. Jacobson, R. Sapolsky // Endocrine Reviews. 1991. — № 12(2). - P.118-134.

41. Wyatt, R.J. Resting plasma catecholamine concentrations in patients with depression and anxiety / R.J. Wyatt // Archives of General Psychiatry. — 1971. — № 24(1). P.65-70.

42. Roy, A. Norepinephrine and its metabolites in cerebrospinal fluid, plasma and urine: relationship to hypo thalamic-pituitary-adrenal axis function in depression / A. Roy, D. Pickar, J. De Jong, [et al.] // Archives of General Psychiatry. — 1988. — № 45. - P.849857.

43. Parissis, J.T. Comparison of circulating proinflammatory cytokines and soluble apoptosis mediators in patients with chronic heart failure with versus without symptoms of depression / J.T. Parissis, S. Adamopoulos, A. Rigas [et al.] // American Journal of Cardiology. - 2004. № 94(10). - P.1326-1328.

44. Young- $X u, Y$. Longterm statin use and psychological wellbeing / Y. Young-Xu, Ch.K. Arnold, K.L. James [et al.] // Journal of the American College of Cardiology. — 2003. № 42(4). - P.690-697.

45. Paulus, W.J. Cytokines and heart failure / W.J. Paulus // Heart failure monitor. — 2000. - № 1(2). - P.50-56.

46. Pasic, J. Cytokines in depression and heart failure / J. Pasic, W.C. Levy, M.D. Sullivan // Psychosomatic Medicine. - 2003. — № 65(2). - P.181-193.

47. Cassell, E.J. Reaction to physical illness and hospitalisation. Psychiatry in General Practice / E.J. Cassell. — New York: Mc Graw-Hill Book Company, 1979. - 126 p.

48. Perlman, L.V. Precipitation of congestive heart failure: social and emotional factors / L.V. Perlman, S. Ferguson, 
K. Bergum [et al.] // Annals of Internal Medicine. — 1971. — № 75(1). - P.1-7.

49. Feenstra, J. Prevention of relapse in patients with congestive heart failure: the role of precipitating factors / J. Feenstra, D.E. Grobbee, F.A. Jonkman [et al.] // Heart. 1998. — № 80 (5). — P.432—436.

50. Giannuzzi, P. Effects of mental exercise in patients with dilated cardiomyopathy and congestive heart failure: An echocardiographic Doppler study / P. Giannuzzi, R. Shabetai, A. Imparato [et al.] // Circulation. - 1991. № 83. - P.155-165.

51. Chapuy, $P$. Depression in elderly patients. Value of tianeptine in 140 patients treated for 1 year / P. Chapuy, G. Cuny, Y. Delomier [et al.] // La Presse Médicale. 1991. — № 20(37). — P.1844-1852.

52. Lasnier, C. Cardiovascular tolerance to tianeptine / C. Lasnier, C. Marey, G. Lapeyre [et al.] // La Presse Médicale. — 1991. — № 20(37). - P.1858-1863.

53. Grignani, G. Platelet activation by emotional stress in patients with coronary artery disease / G. Grignani, F. Soffiantino, M. Zucchella [et al.] // Circulation. 1991. — № 83. - P.128-136.

54. Allen, M.T. Hemoconcentration and stress: a review of physiological mechanisms and relevance for cardiovascular disease / M.T. Allen, S.M. Patterson // Biological Psychology. - 1995. — № 41(1). - P.1-27.

55. Lowe, G.D. Blood viscosity and risk of cardiovascular events: the Edinburgh Artery Study / G.D. Lowe, A.J. Lee, A. Rumley // British Journal of Haematology. — 1997. № 96(1). - P.168-173.

56. Scherrer, J.F. A twin study of depression symptoms, hypertension, and heart disease in middle-aged men / J.F. Scherrer, H. Xian, K.K. Bucholz // Psychosomatic Medicine. - 2003. — № 65(4). - P.548-557.

57. Baghai, T.C. Polymorphisms in the angiotensinconvertingenzyme gene are associated with unipolar depression, ACE activity and hypercortisolism / T.C. Baghai, E.B. Binder, C. Schule // Molecular Psychiatry. - 2006. № 11. - P.1003-1015.

58. Jezova, $D$. Brain angiotensin II modulates sympathoadrenal and hypothalamic pituitary adrenocortical activation during stress / D. Jezova, T. Ochedalski, A. Kiss [et al.] // Neuroendocrinology. - 1998. — № 10(1). - P.67-72.

59. Murck, $H$. The renin-angiotensin-aldosterone system in patients with depression compared to controls - a sleep endocrine study / H. Murck, K. Held, M. Ziegenbein // BMC Psychiatry. - 2003. - № 3. - P.15.

60. Murberg, T.A. Depressive symptoms and mortality in patients with congestive heart failure: a sixyear followup study / T.A. Murberg, G. Furze // Medical Science Monitor. — 2004. — № 10(12). - P.643-648.

61. Jünger, J. Depression increasingly predicts mortality in the course of congestive heart failure / J. Jünger, D. Schellberg, T. Müller-Tasch // European Journal of Heart Failure. - 2005. - № 7(2). - P.261-267.

62. Sullivan, M.D. Usefulness of depression to predict time to combined end point of transplant or death for outpatients with advanced heart failure / M.D. Sullivan, W.C. Levy, B.A. Crane // American Journal of Cardiology. — 2004. № 94(12). - P.1577-1580.

63. Clary, G.L. Effects of antidepressant medication on mortality in patients with congestive heart failure (abstract) / G.L. Clary, C. Davenport, D. Biracree // Journal of the American College of Cardiology. - 2002. — № 39. P.168.

64. Massie, B.M. Evolving trends in the epidemiologic factors of heart failure: rationale for preventive strategies and comprehensive disease management / B.M. Massie, N.B. Shah // American Heart Journal. - 1997. № 133. - P.703-712.
65. Himelhoch, S. Chronic medical illness, depression, and use of acute medical services among Medicare beneficiaries / S. Himelhoch, W.E. Weller, A.W. Wu [et al.] // Medical Care. — 2004. — № 42(6). - P.512-521.

66. Rumsfeld, J.S. Depressive symptoms are the strongest predictors of short term declines in health status in patients with heart failure / J.S. Rumsfeld, E. Havranek, F.A. Masoudi [et al.] // Journal of the American College of Cardiology. — 2003. — № 42(10). - P.1811-1817.

67. Care/s, R.A. The association between disease severity, functional status, depression and daily quality of life in congestive heart failure patients / R.A. Carels // Quality of Life Research. — 2004. — № 13(1). - P.63-72.

68. Sullivan, M.D. Depression and health status in elderly patients with heart failure: a 6month prospective study in primary care / M.D. Sullivan, K. Newton, J. Hecht [et al.] // The American Journal of Geriatric Cardiology. — 2004. № $13(5)$. - P.252-260.

69. Gottdiener, J.S. Induction of silent myocardial ischemia with mental stress testing: relation to the triggers of ischemia during daily life activities and to ischemic functional severity / J.S. Gottdiener, D.S. Krantz, R.H. Howell [et al.] // Journal of the American College of Cardiology. — 1994. № 24(7). - P.1645-1651.

70. Murberg, T.A. Functional status and depression among men and women with congestive heart failure / T.A. Murberg, E. Bru, T. Aarsland [et al.] // International Journal of Psychiatry in Medicine. - 1998. — № 28(3). - P.273291.

71. Gard, P.R. Angiotensin as a target for the treatment of Alzheimer's disease, anxiety and depression / P.R. Gard // Expert Opinion on Therapeutic Targets. - 2004. № 8(1). - P.7-14.

72. Vaccarino, V. Depressive symptoms and risk of functional decline and death in patients with heart failure / V. Vaccarino, S.V. Kasl, J. Abramson [et al.] // Journal of the American College of Cardiology. — 2000. — № 38(1). P.199-205.

\section{REFERENCES}

1. Belenkov, Yu.N. Cerdechno-sosudistyi kontinuum [Cardiovascular continuum] / Yu.N. Belenkov, V.Yu. Mareev // Serdechnaya nedostatochnost'. — 2002. — № 11. S.7-11.

2. Ostroumova, O.D. Arterial'naya gipertoniya i kognitivnye funkcii [Arterial hypertension and cognitive function] / O.D. Ostroumova // Effektivnaya farmakoterapiya. 2013. - № 16. - S.16-22.

3. Kryukov, N.N. Vozmozhnosti korrekcii kognitivnyh narushenii pri gipertonicheskoi bolezni i paroksizmal'noi fibrillyacii predserdii [Correction capabilities of cognitive impairment in hypertensive disease and paroxysmal atrial fibrillation] / N.N. Kryukov, E.V. Portnova // Rossiiskii mediko-biologicheskii vestnik im. akademika I.P. Pavlova. - 2013. - № 1. - S.88-93.

4. Lazareva, E. Yu. Nekotorye psihologicheskie harakteristiki pacientov s kardial'noi patologiej [Some of the psychological characteristics of patients with cardiac pathology] / E.Yu. Lazareva, E.L. Nikolaev // Prikladnye informacionnye aspekty mediciny. - 2014. - T. 17, № 1. - S.87-93.

5. Derevina, E.S. Kognitivnye narusheniya pri fibrillyacii predserdii na fone serdechno-sosudistyh narushenij [Cognitive impairment in atrial fibrillation on a background of cardiovascular disorders] / E.S. Derevina, N.S. Akimova, T.V. Martynovich [i dr.] // Annaly aritmologii. — 2013. T. 10, № 2. - S.87-94.

6. Anufrieva, T.V. Osobennosti kognitivnogo statusa bol'nyh $s$ paroksizmal'noi formoi fibrillyacii predserdij [Features the cognitive status of patients with paroxysmal atrial 
fibrillation] / T.V. Anufrieva, S.L. Postnikova, V.A. Anufrieva [I dr.] // Lechebnoe delo. — 2014. — № 1. — S.55—62.

7. Yahno, N.N. Kognitivnye rasstroistva $v$ nevrologicheskoi klinike [Cognitive impairment in neurological clinic] / N.N. Yahno // Nevrologicheskii zhurnal. — 2006. — № 11, pril. 1. - S.4-12.

8. Smulevich, A.B. Depressii pri somaticheskih i psihicheskih zabolevaniyah [Depression by somatic and mental diseases] / A.B. Smulevich. - M., 2003. - 423 s.

9. Pogosova, G.V. Depressiya: novyi faktor riska IBS prediktor koronarnoi smerti [Depression: two new fatora risk of coronary heart disease and a predictor of coronary death] / G.V. Pogosova // Kardiologiya. — 2002. — № 4. S.86-90.

10. Resina, I.A. Vyyavlenie sostoyanii depressii i trevogi, kachestvo zhizni u bol'nyh hronicheskoi serdechnoi nedostatochnost'yu [Identifying depression and anxiety, quality of life in patients with chronic heart failure] / I.A. Resina // Aktual'nye voprosy voennoi i prakticheskoi mediciny: sb. tr. II nauch.-prakt. konf. vrachei PrivolzhskoUral'skogo voennogo okruga. - Orenburg, 2001. S.220-223.

11. Cross-National Collaborative Group. The changing rate of major depression. Cross-national comparisons (review) // JAMA. — 1992. — № 268. — P.3098-3105.

12. Mosolov, S.N. Aktual'nye voprosy farmakoterapii depressii. Novye dostizheniya v terapii psihicheskih zabolevanii [Actual issues of pharmacotherapy of depression. New advances in the treatment of mental illness] / S.N. Mosolov, E.G. Kostyukova. M.: Izd-vo BINOM, 2002. - S.211-232.

13. Costa-e-Silva, J.A. Facing depression. Editorial / J.A. Costae-Silva // WPA Teaching Bulletin on Depression. 1993. — № 1. - P.11.

14. Lecrubier, Y. Depression in medical practice / Y. Lecrubier // WPA Teaching Bulletin on Depression. - 1993. T. 1. - P.1-2.

15. Dunham, N.C. Functional status, symptoms of depression, and the outcomes of hospitalization in community-dwelling elderly patients / N.C. Dunham, M.A. Sager // Archives of Family Medicine. — 1994. — № 3. - P.676-681.

16. Jaffe, A. Minor depression and functional impairment / A. Jaffe, J. Froom, N. Galambos // Archives of Family Medicine. - 1994. - № 3. - P.1081-1086.

17. Empana, J.P. Clinical depression and risk of out-of-hospital cardiac arrest / J.P. Empana, X. Jouven, R.N. Lemaitre [et al.] // Archives of Internal Medicine. - 2006. № 166. - P.195-200.

18. Kessler, R.C. Lifetime and 12-month prevalence of DSMIII-R psychiatric disorders in the United States: results from the National Comorbidity Survey / R.C. Kessler, K.A. McGonagle, S. Zhao [et al.] // Archives of General Psychiatry. - 1994. - № 51. - P.8-19.

19. Jiang, $W$. Relationship of depression to increased risk of mortality and rehospitalization in patients with congestive heart failure / W. Jiang, J. Alexander, E. Christopher [et al.] // Archives of Internal Medicine. — 2001. — № 161. P.1849-1856.

20. Vatutin, N.T. Kardiologiya [Cardiology] / N.T. Vatutin. Doneck: Izd-vo Kashtan, 2008. - 446 s.

21. Katon, W. Epidemiology of depression in primary care / W. Katon, H. Schulberg // General Hospital Psychiatry. 1992. — № 14. — P.237-247.

22. Ustan, T.B. New classification for mental disorders with management guidelines for use in primary care / T.B. Ustan, D. Goldberg, J. Cooper [et al.] // British Journal of General Practice. - 1995. — № 45. - P.211-215.

23. Carney, R.M. Depression and coronary heart disease: a review for cardiologists / R.M. Carney, K.E. Freeland, Y.I. Sheline // Clinical Cardioljgy. — 1997. — № 20. P.196-200.
24. Cunningham, L.A. Depression in the medically ill: Choosing an antidepressant / L.A. Cunningham // Journal of Clinical Psychiatry. - 1994. — № 55. - P.90-100.

25. Chazov, E.I. Kliniko-epidemiologicheskaya programma izucheniya depressii v kardiologicheskoi praktike; u bol'nyh arterial'noi gipertoniei i ishemicheskoi bolezn'yu serdca (koordinata) [Clinico-epidemiological study of depression program in cardiology practice in patients with arterial hypertension and ischemic heart disease] / E.I. Chazov, R.G. Oganov, G.V. Pogosova [l dr.] // Kardiologiya. 2005. - № 11. - S.4-11.

26. Oganov, R.G. Rasprostranennost' depressii v obschei praktike: masshtaby problem [Prevalence of depression in general practice: the scale of the problem] / R.G. Oganov // Depressiya v kardiologii: bol'she, chem faktor riska: materialy simp. III Ros. nac. kongr. kardiologov. - M., 2003. - S.1-4.

27. Diagnostic and statistical manual of mental disorders. $4^{\text {th }}$ ed. - DSMIV. - Washington, D.C.: American Psychiatric Association. - 1994. - P.511-518.

28. Larson, S.L. Depressive disorder, Dysthymia, and Risk of Stroke / S.L. Larson, P.L. Owens, D. Ford. // Stroke. - 2001. — № 32. - P.19-79.

29. Barsky, A.J. Palpitations, cardiac awareness, and panic disorder / A.J. Barsky // American Journal of Medicine. - 1992. — № 92. - P.315-345.

30. Crum, R.M. Depressive symptoms among general medical patients: prevalence and one-year outcome / R.M. Crum, L. Cooper-Patrick, D.E. Ford // Psychosomatic Medicine. - 1994. — № 56. — P.109-117.

31. Vasyuk, Yu.A. Depressii pri hronicheskoi serdechnoi nedostatochnosti ishemicheskogo geneza [Depression in chronic heart failure of ischemic origin] / Yu.A. Vasyuk, T.V. Dovzhenko, E.L. Shkol'nik // Serdechnaya nedostatochnost'. - 2004. - № 5(3). - S.140-146.

32. Vein, A.M. Depressiya v nevrologicheskoi praktike [Depression in neurological practice] / A.M. Vein, T.G. Voznesenskaya, V.L. Golubev [i dr.]. - M.: MIA, 2002. $-155 \mathrm{~s}$.

33. Damulin, I.V. Bolezn' Al'cgeimera i sosudistaya demenciya [Alzheimer's disease and vascular dementia] / I.V. Damulin; pod red. N.N. Yahno. - M., 2002. - 85 s.

34. Oganov, R.G. Depressivnye rasstroistva v obschemedicinskoi praktike po dannym issledovaniya KOMPAS: vzglyad kardiologa [Depressive disorders in general practice according to the study COMPASS: a view of the cardiologist] / R.G. Oganov // Kardiologiya. — 2005. № 8. - S.37-43.

35. Plotsky, P.M. Psychoneuroendocrinology of depression. Hypothalamic-pituitary-adrenal axis / P.M. Plotsky, M.J. Owens, C.B. Nemeroff // Psychiatric Clinics of North America. — 1998. — № 21(2). - P.293-307.

36. Jackson, I.M. The thyroid axis and depression / I.M. Jackson // Thyroid. - 1998. — № 8. - P.951-956.

37. Maes, $M$. The immunoregulatory effects of antidepressants / M. Maes // Human Psychopharmacology. 2001. — № 16(1). - P.95-103.

38. Veith, R.C. Sympathetic nervous system activity in major depression. Basal and desipramine-induced alterations in plasma nor epinephrine kinetics / R.C. Veith // Archives of General Psychiatry. - 1994. — № 51(5). - P.411-422.

39. Syrkin, A.L. Pacienty so stenokardiei, rezistentnoi k monoterapii antianginal'nymi preparatami [Patients with angina resistant to monotherapy antianginal drugs] / A.L. Syrkin // Consilium medicum. Ekstravypusk. 2003. - S.5-7.

40. Jacobson, $L$. The role of the hippocampus in feedback regulation of the hypothalamic-pituitary-adrenocortical axis / L. Jacobson, R. Sapolsky // Endocrine Reviews. 1991. — № 12(2). — P.118-134. 
41. Wyatt, R.J. Resting plasma catecholamine concentrations in patients with depression and anxiety / R.J. Wyatt // Archives of General Psychiatry. — 1971. — № 24(1). P.65-70.

42. Roy, A. Norepinephrine and its metabolites in cerebrospinal fluid, plasma and urine: relationship to hypothalamicpituitary-adrenal axis function in depression / A. Roy, D. Pickar, J. De Jong, [et al.] // Archives of General Psychiatry. — 1988. — № 45. - P.849-857.

43. Parissis, J.T. Comparison of circulating proinflammatory cytokines and soluble apoptosis mediators in patients with chronic heart failure with versus without symptoms of depression / J.T. Parissis, S. Adamopoulos, A. Rigas [et al.] // American Journal of Cardiology. 2004. — № 94(10). — P.1326-1328.

44. Young- $X u, Y$. Longterm statin use and psychological wellbeing / Y. Young-Xu, Ch.K. Arnold, K.L. James [et al.] // Journal of the American College of Cardiology. - 2003. № 42(4). - P.690-697.

45. Paulus, W.J. Cytokines and heart failure / W.J. Paulus // Heart failure monitor. - 2000. — № 1(2). - P.50-56.

46. Pasic, J. Cytokines in depression and heart failure / J. Pasic, W.C. Levy, M.D. Sullivan // Psychosomatic Medicine. - 2003. - № 65(2). - P.181-193.

47. Cassell, E.J. Reaction to physical illness and hospitalisation. Psychiatry in General Practice / E.J. Cassell. New York: Mc Graw-Hill Book Company, 1979. - 126 p.

48. Perlman, L.V. Precipitation of congestive heart failure: social and emotional factors / L.V. Perlman, S. Ferguson, K. Bergum [et al.] // Annals of Internal Medicine. - 1971. — № 75(1). — P.1-7.

49. Feenstra, J. Prevention of relapse in patients with congestive heart failure: the role of precipitating factors / J. Feenstra, D.E. Grobbee, F.A. Jonkman [et al.] // Heart. 1998. — № 80 (5). — P.432-436.

50. Giannuzzi, P. Effects of mental exercise in patients with dilated cardiomyopathy and congestive heart failure: An echocardiographic Doppler study / P. Giannuzzi, R. Shabetai, A. Imparato [et al.] // Circulation. - 1991. № 83. - P.155-165.

51. Chapuy, $P$. Depression in elderly patients. Value of tianeptine in 140 patients treated for 1 year / P. Chapuy, G. Cuny, Y. Delomier [et al.] // La Presse Médicale. 1991. — № 20(37). - P.1844-1852.

52. Lasnier, C. Cardiovascular tolerance to tianeptine / C. Lasnier, C. Marey, G. Lapeyre [et al.] // La Presse Médicale. - 1991. — № 20(37). - P.1858-1863.

53. Grignani, G. Platelet activation by emotional stress in patients with coronary artery disease / G. Grignani, F. Soffiantino, M. Zucchella [et al.] // Circulation. 1991. — № 83. - P.128-136.

54. Allen, M.T. Hemoconcentration and stress: a review of physiological mechanisms and relevance for cardiovascular disease / M.T. Allen, S.M. Patterson // Biological Psychology. - 1995. — № 41(1). - P.1-27.

55. Lowe, G.D. Blood viscosity and risk of cardiovascular events: the Edinburgh Artery Study / G.D. Lowe, A.J. Lee, A. Rumley // British Journal of Haematology. - 1997. № 96(1). - P.168-173.

56. Scherrer, J.F. A twin study of depression symptoms, hypertension, and heart disease in middle-aged men / J.F. Scherrer, H. Xian, K.K. Bucholz // Psychosomatic Medicine. - 2003. - № 65(4). - P.548-557.

57. Baghai, T.C. Polymorphisms in the angiotensinconvertingenzyme gene are associated with unipolar depression, ACE activity and hypercortisolism / T.C. Baghai, E.B. Binder, C. Schule // Molecular Psychiatry. - 2006. № 11. - P.1003-1015.

58. Jezova, $D$. Brain angiotensin II modulates sympathoadrenal and hypothalamic pituitary adrenocortical activation during stress / D. Jezova, T. Ochedalski, A. Kiss [et al.] // Neuroendocrinology. — 1998. — № 10(1). — P.67-72.

59. Murck, $H$. The renin-angiotensin-aldosterone system in patients with depression compared to controls - a sleep endocrine study / H. Murck, K. Held, M. Ziegenbein // BMC Psychiatry. - 2003. - № 3. - P.15.

60. Murberg, T.A. Depressive symptoms and mortality in patients with congestive heart failure: a sixyear followup study / T.A. Murberg, G. Furze // Medical Science Monitor. - 2004. — № 10(12). - P.643-648.

61. Jünger, J. Depression increasingly predicts mortality in the course of congestive heart failure / J. Jünger, D. Schellberg, T. Müller-Tasch // European Journal of Heart Failure. - 2005. — № 7(2). - P.261-267.

62. Sullivan, M.D. Usefulness of depression to predict time to combined end point of transplant or death for outpatients with advanced heart failure / M.D. Sullivan, W.C. Levy, B.A. Crane // American Journal of Cardiology. 2004. — № 94(12). - P.1577-1580.

63. Clary, G.L. Effects of antidepressant medication on mortality in patients with congestive heart failure (abstract) / G.L. Clary, C. Davenport, D. Biracree // Journal of the American College of Cardiology. - 2002. - № 39. P.168.

64. Massie, B.M. Evolving trends in the epidemiologic factors of heart failure: rationale for preventive strategies and comprehensive disease management / B.M. Massie, N.B. Shah // American Heart Journal. - 1997. № 133. - P.703-712.

65. Himelhoch, S. Chronic medical illness, depression, and use of acute medical services among Medicare beneficiaries / S. Himelhoch, W.E. Weller, A.W. Wu [et al.] // Medical Care. — 2004. — № 42(6). — P.512521.

66. Rumsfeld, J.S. Depressive symptoms are the strongest predictors of short term declines in health status in patients with heart failure / J.S. Rumsfeld, E. Havranek, F.A. Masoudi [et al.] // Journal of the American College of Cardiology. - 2003. — № 42(10). - P.1811-1817.

67. Care/s, R.A. The association between disease severity, functional status, depression and daily quality of life in congestive heart failure patients / R.A. Carels // Quality of Life Research. - 2004. - № 13(1). P.63-72.

68. Sullivan, M.D. Depression and health status in elderly patients with heart failure: a 6month prospective study in primary care / M.D. Sullivan, K. Newton, J. Hecht [et al.] // The American Journal of Geriatric Cardiology. 2004. — № 13(5). — P.252-260.

69. Gottdiener, J.S. Induction of silent myocardial ischemia with mental stress testing: relation to the triggers of ischemia during daily life activities and to ischemic functional severity / J.S. Gottdiener, D.S. Krantz, R.H. Howell [et al.] // Journal of the American College of Cardiology. - 1994. № 24(7). - P.1645-1651.

70. Murberg, T.A. Functional status and depression among men and women with congestive heart failure / T.A. Murberg, E. Bru, T. Aarsland [et al.] // International Journal of Psychiatry in Medicine. — 1998. — № 28(3). P.273-291.

71. Gard, P.R. Angiotensin as a target for the treatment of Alzheimer's disease, anxiety and depression / P.R. Gard // Expert Opinion on Therapeutic Targets. - 2004. № 8(1). - P.7-14.

72. Vaccarino, $V$. Depressive symptoms and risk of functional decline and death in patients with heart failure / V. Vaccarino, S.V. KasI, J. Abramson [et al.] // Journal of the American College of Cardiology. — 2000. - № 38(1). P.199-205.

Принята 11.11.2014 


\title{
ИСПОЛЬЗОВАНИЕ ТЕХНОЛОГИИ РИСК-МЕНЕДЖМЕНТА ДЛЯ ПОВЫШЕНИЯ ЭФФЕКТИВНОСТИ ПЕРВИЧНОЙ ПРОФИЛАКТИКИ ИНФАРКТА МИОКАРДА
}

АЛЕКСАНДР МИХАЙЛОВИЧ НАЗАРОВ, канд. мед. наук, зав. отделением реанимации и интенсивной терапии ГБУЗ «Оренбургская областная клиническая больница», Оренбург, Россия, тел. 8-903-367-96-51,

e-mail: a.m.nazarow@yandex.ru

Реферат. Цель исследования - выделить группы больных с наибольшей вероятностью развития инфаркта миокарда (ИМ) и имевших наибольшие затраты на лечение для эффективного и экономного проведения первичной профилактики ИМ. Материал и методы. По базе данных медицинской страховой компании (МСК) электронным способом обработано 5186056 обращений, в том числе 615519 пациентов, обратившихся в учреждения здравоохранения области [поликлиника, скорая медицинская помощь (СМП), стационар] по поводу стенокардии, артериальной гипертонии (АГ), ИМ в течение 2012-2013 гг. Прослежена связь между стенокардией и ИМ, АГ и ИМ, прочими заболеваниями и ИМ. Результаты и их обсуждение. Выявлено, что вероятность развития ИМ у больных, обращавшихся за медицинской помощью со стенокардией, в 13 раз больше, чем у больных АГ, и в 39 раз больше по сравнению с теми, кто за медицинской помощью в учреждения здравоохранения области обращался с другими заболеваниями. Наибольшая вероятность развития ИМ среди больных со стенокардией наблюдалась в возрастных группах до 45 лет и от 45 до 59 лет. У мужчин вероятность развития ИМ была в 1,9 раза больше, чем у женщин. С увеличением числа обращений больных стенокардией в стационар и СМП возрастали вероятность ИМ и стоимость лечения. Заключение. С целью получения максимального клинического и экономического эффректа от первичной профилактики ИМ ее следует проводить и соответственно тратить средства в первую очередь на больных стенокардией в возрастной группе до 45 лет и от 45 до 59 лет, предпочтительно на мужчин, а также на больных, наиболее часто обращающихся за медицинской помощью по поводу стенокардии в СМП и стационар.

Ключевые слова: профилактика инфаркта миокарда, стенокардия, вероятность.

\section{APPLYING RISK-MANAGEMENT TECHNOLOGY FOR EFFECTIVIZATION THE PRIMARY PREVENTION OF MYOCARDIAL INFARCTION}

ALEKCANDER M. NAZAROV, Ph.D., Chief of Department intensive therapy, Orenburg Regional Clinical Hospital, Orenburg, Russia, tel. 8-903-367-96-51, e-mail: a.m.nazarow@yanex.ru

\begin{abstract}
Aim. The purpose of this study is to separate groups of patients with the high risk of myocardial infarction development and high treatment cost for effective and economy primary prevention of myocardial infarction. Matherial and method. A database of health insurance company was used. We have processed 5186056 medical records of 615519 patients who had sought medical advice in medical organizations (an outpatient, an inpatient department or an Emergency Call Service) for different cases including angina, arterial hypertension, myocardial infarction in 2012-2013 years. The correlations were found between angina and myocardial infarction, arterial hypertension and myocardial infarction, the other diseases and myocardial infarction. Results. It was found that the risk of myocardial infarction development in patients with angina was 13 times more than in patients with arterial hypertension and 39 times more than patients with the other diseases. The highest risk of myocardial infarction development was observed in age groups up to 45 years and from 45 up to 59 years. The risk of myocardial infarction development in men was 1,9 times more than in women. With more hospital admissions and ambulance call-outs of patients with angina risk of myocardial infarction development and its treatment cost increase. Conclusion. In order to receive maximum clinical and economic benefits from primary prevention of myocardial infarction it should be performed for patients with angina, in age up to 45 years and from 45 up to 59 years old, mostly for men, and for patients with most frequent hospital admissions and ambulance call-outs with angina.
\end{abstract}

Key words: prevention of myocardial infarction, angina, probability.

$\mathrm{B}$ течение ряда последних десятилетий сердечно-сосудистые заболевания (СС3), в частности инфраркт миокарда (ИМ), занимают 1-е место в общей структуре причин смертности и инвалидизации населения во всем мире $[5,7]$. Это диктует исключительную важность организационных мероприятий по профилактике, раннему выявлению и адекватному лечению ССЗ; созданию алгоритмов диффреренцированного подхода к оказанию помощи на амбулаторно-поликлиническом и стационарном этапах [6]. Результаты крупных международных исследований свидетельствуют, что осуществление профилактики больных ССЗ в соответствии с принципами, изложенными в общепринятых стандартах, позволяет добиться значительного снижения частоты сердечно-сосудистых 
осложнений, а также инвалидности и смертности [9]. Однако разрыв между медицинской наукой и практической медициной продолжает сохраняться. Ряд отечественных исследований, посвященных данной проблеме в кардиологии, выявил несоответствие реальной врачебной практики международным стандартам, в частности в области профилактики и лечения ИБС [10]. В настоящее время диспансеризация как профилактическая технология имеет низкую эфффективность [8], так как многие ее составляющие до конца не разработаны в организационном и методологическом плане [11].

Решение этих задач возможно с использованием методов риск-менеджмента на основе электронных баз данных медицинских страховых компаний (МСК) и фонда обязательного медицинского страхования (ОМС), которые содержат инфрормацию о результатах работы всех учреждений здравоохранения, работающих по программе ОМС. Данная информация ежемесячно пополняется в форме подаваемых на оплату лечебно-профилактическими учреждениями персонифицированных счетов-реестров. Внедрение системы управления рисками (риск-менеджмент) в здравоохранение, включающих в себя выявление, идентификацию, оценку, прогноз, профилактику рисков, мониторинг рисковых событий, направлено на повышение эффеективности и качества оказания медицинской помощи [1]. Современный подход к управлению рисками базируется на парадигме стоимости риска [4]

Цель исследования - эффрективное проведение первичной профилактики ИМ среди больных, обращающихся в учреждения здравоохранения за медицинской помощью, выделение группы больных с наибольшей вероятностью развития ИМ и имеющих наибольшие затраты на лечение.

Материал и методы. Обработано 5186056 обращений в лечебные учреждения области (поликлиника, скорая помощь, стационар) с различными заболеваниями, в том числе со стенокардией, артериальной гипертонией (АГ) и ИМ, сделанных в 2012 и 2013 гг. 615519 пациентами старше 20 лет из числа 670000 застрахованных, имеющих полис обязательного медицинского страхования МСК «Согаз-мед», филиал в г. Оренбурге. При обработке исходных данных использовались методы линейной статистики (нахождение среднего арифметического, дисперсии, стандартного отклонения, вероятностные характеристики, такие как условная вероятность события, формула Байеса, а также параметрические и непараметрические методы сравнения (t-критерий, U-критерий Вилкоксона, критерий $\chi^{2}$ Пирсона, ранговый коэффициент Спирмена) [3]. Обработка проводилась с помощью пакета программ Statistica 10 (Stat Soft, Ink., США) [2]. Оценивали следующие фракторы: возрастная группа, пол (переменная), наличие стенокардии, наличие АГ.

Результаты и их обсуждение. Анализ полученных данных показал, что вероятность развития ИМ у лиц, обращавшихся за медицинской помощью со стенокардией, существенно больше по сравнению с теми, кто за медицинской помощью с диагнозом «стенокардия» в учреждения здравоохранения области не обращались (табл. 1). Соответственно риск развития ИМ, исходя из данных вероятности ИМ, у первых был в 39 раз больше, чем у вторых 0,054262 : 0,001392=38,99.

При анализе развития ИМ в возрастных группах до 45 лет, от 45 до 59 лет и от 60 лет и старше вероятность ИМ в каждой возрастной группе была значительно больше у больных со стенокардией, чем у лиц, не обращавшихся за медицинской помощью с этим диагнозом (табл. 2). Причем вероятность развития ИМ у больных со стенокардией в группах до 45 лет и от 45 до 59 лет была максимальной.

Исходя из полученных данных, вероятность развития ИМ у больных со стенокардией и без нее (см. табл. 2): в возрастной группе до 45 лет риск

Та блица 1

Вероятность появления инфаркта миокарда при анализе пар заболеваний стенокардии и инфаркта миокарда у 615519 пациентов

\begin{tabular}{|l|c|c|c|}
\hline \multicolumn{1}{|c|}{ Признак } & У пациента не было ИМ & У пациента был ИМ & $\begin{array}{c}\text { Сумма вероятностей } \\
\text { по строке }\end{array}$ \\
\hline $\begin{array}{l}\text { У пациентов не было обращений } \\
\text { со стенокардией }\end{array}$ & 0,998608 & 0,001392 \\
\hline $\begin{array}{l}\text { У пациента было хотя бы одно обра- } \\
\begin{array}{l}\text { щение в медицинскую организацию } \\
\text { по поводу стенокардии }\end{array}\end{array}$ & & 1,000000 \\
\hline
\end{tabular}

Вероятность появления инфаркта миокарда при анализе 3 пар признаков: возрастная группа $\rightarrow$ стенокардия $\rightarrow$ инфаркт миокарда у 615519 пациентов

\begin{tabular}{|l|l|c|c|c|}
\hline \multicolumn{1}{|c|}{ Признак 1 } & \multicolumn{1}{|c|}{ Признак 2 } & Нет инфаркта миокарда & Есть инфаркт миокарда & Всего по строке \\
\hline До 45 лет & Нет стенокардии & 0,99986 & 0,00014 & 1,00000 \\
\hline До 45 лет & Есть стенокардия & 0,93038 & 0,06962 & 1,00000 \\
\hline 45-59 лет & Нет стенокардии & 0,99813 & 0,00187 & 1,00000 \\
\hline 45-59 лет & Есть стенокардия & 0,92922 & 0,07078 & 1,00000 \\
\hline 60 лет и старше & Нет стенокардии & 0,99452 & 0,05026 & 1,00000 \\
\hline 60 лет и старше & Есть стенокардия & 0,94974 & 1,00000 \\
\hline
\end{tabular}


ИМ у больных со стенокардией превышал риск ИМ у больных без стенокардии в 502 раза $(0,6962$ : 0,00014=502,2), в группе 45-59 лет - в 38 раз $(0,07078: 0,00187=37,8)$; в группе 60 лет и старше — в 9 раз $(0,05026: 0,00548=9,2)$.

Проведенные расчеты вероятности развития ИМ с учетом пола пациента, наличия или отсутствия обращений за медицинской помощью по поводу стенокардии показали, что как у мужчин, так и у женщин вероятность развития ИМ достоверно выше при наличии обращений по поводу стенокардии (табл. 3). При этом, исходя из данных табл. 3, вероятность развития ИМ в случае обращений со стенокардией у мужчин была в 1,9 раза больше, чем у женщин $(0,07499: 0,03989=1,9)$.

Расчеты вероятности развития ИМ у пациентов, обращавшихся за медицинской помощью как со стенокардией, так и с АГ, только со стенокардией и только с АГ, а также при отсутствии стенокардии и АГ, выявили максимальную вероятность развития ИМ в группе больных со стенокардией и артериальной гипертонией - 5,5\%, несколько меньшую в группе больных только со стенокардией $-5,4 \%$, существен- но меньшую в группах больных только с АГ- $-42 \%$ и при отсутствии стенокардии и АГ - 0,12\% (табл. 4). Соответственно риск развития ИМ в группе больных со стенокардией и АГ по сравнению с теми, кто со стенокардией и АГ не обращались за медицинской помощью, был в 47,4 раза больше - 0,05494 : $0,00116=47,4$. Исходя из данных вероятности развития ИМ у больных стенокардией и у больных АГ (см. табл. 4), риск развития ИМ у первых в 13 раз больше, чем у вторых $(0,05386: 0,00415=12,98)$.

Расчет рангового коэффициента Спирмена $\left(r_{s}=0,257\right)$ показал, что между количеством больных, обратившихся в стационар и(или) в СМП по поводу стенокардии, и теми же больными, имеющими ИМ, существует слабая, но статистически достоверная $(p<0,05)$ корреляционная связь. Данный фракт означает, что с ростом числа обращений больного в стационар и СМП увеличивается риск развития ИМ. Вероятно, это связано с тем, что данные больные более тяжелые и соответственно требуют большего внимания в поликлинике при первичной профилактике ИМ. По табл. 5 были выбраны больные с числом обращений в СМП и стационар 5 и более раз.

Та блиц а 3

Вероятность появления инфаркта миокарда при анализе 3 пар признаков: пол пациента $\rightarrow$ стенокардия $\rightarrow$ инфаркт миокарда у 615519 пациентов

\begin{tabular}{|l|l|c|c|c|}
\hline \multicolumn{1}{|c|}{ Признак 1 } & \multicolumn{1}{|c|}{ Признак 2 } & Нет инфаркта миокарда & Есть инфаркт миокарда & Всего по строке \\
\hline Мужской & Нет стенокардии & 0,99817 & 0,00183 & 1,00000 \\
\hline Мужской & Есть стенокардия & 0,92501 & 0,07499 & 1,00000 \\
\hline Женский & Нет стенокардии & 0,99893 & 0,00107 & 1,00000 \\
\hline Женский & Есть стенокардия & 0,96011 & 0,03989 & 1,00000 \\
\hline
\end{tabular}

Вероятность появления инфаркта миокарда при анализе 3 пар признаков: гипертония $\rightarrow$ стенокардия $\rightarrow$ инфаркт миокарда у 615519 пациентов

\begin{tabular}{|l|l|c|c|c|}
\hline \multicolumn{1}{|c|}{ Признак 1 } & \multicolumn{1}{|c|}{ Признак 2 } & Нет инфаркта миокарда & Есть инфаркт миокарда & Всего по строке \\
\hline Нет АГ & Нет стенокардии & 0,99884 & 0,00116 & 1,00000 \\
\hline Нет АГ & Есть стенокардия & 0,94614 & 0,05386 & 1,00000 \\
\hline АГ есть & Нет стенокардии & 0,99585 & 0,00415 & 1,00000 \\
\hline АГ есть & Есть стенокардия & 0,94506 & 0,05494 & 1,00000 \\
\hline
\end{tabular}

Финансовые затраты в группах больных стенокардией в зависимости от количества вызовов скорой медицинской помощи и числа госпитализаций в стационар

\begin{tabular}{|c|c|c|c|c|c|}
\hline $\begin{array}{l}\text { Номер } \\
\text { группы }\end{array}$ & $\begin{array}{c}\text { Количество } \\
\text { больных }\end{array}$ & $\begin{array}{c}\text { Число обращений } \\
\text { на } 1 \text { больного }\end{array}$ & $\begin{array}{l}\text { Число обращений } \\
\text { на всех больных }\end{array}$ & $\begin{array}{c}\text { Сумма затрат средств ОМС } \\
\text { на всех больных в руб. }\end{array}$ & $\begin{array}{c}\text { Средние затраты } \\
\text { на } 1 \text { больного в группе в руб. }\end{array}$ \\
\hline 1 & 15713 & 1 & 15713 & 48898912,70 & 3112,00 \\
\hline 2 & 6961 & 2 & 13922 & 44427908,99 & 6382,40 \\
\hline 3 & 3774 & 3 & 11322 & 32129938,72 & 8513,50 \\
\hline 4 & 2459 & 4 & 9836 & 23949451,44 & 9739,51 \\
\hline 5 & 1656 & 5 & 8280 & 19213672,99 & 11602,46 \\
\hline 6 & 1211 & 6 & 7266 & 15611547,53 & 12891,45 \\
\hline 7 & 881 & 7 & 6167 & 13183588,40 & 14964,35 \\
\hline 8 & 668 & 8 & 5344 & 10309024,01 & 15432,67 \\
\hline 9 & 492 & 9 & 4428 & 8199419,89 & 16665,49 \\
\hline 10 & 421 & 10 & 4210 & 6346842,85 & 15075,64 \\
\hline 11 & 1364 & $11-20$ & 18587 & 30066724,53 & 22043,05 \\
\hline 12 & 201 & $21-30$ & 4664 & 6651168,92 & 33090,39 \\
\hline 13 & 25 & $31-40$ & 833 & 1101659,47 & 44066,38 \\
\hline 14 & 9 & $41-50$ & 396 & 534157,10 & 59350,79 \\
\hline 15 & 3 & $51-60$ & 153 & 3828,87 & 1276,29 \\
\hline 16 & 3 & $61-70$ & 180 & 386088,34 & 128696,11 \\
\hline 17 & 3 & более 70 & 484 & 777399,36 & 259133,12 \\
\hline
\end{tabular}


Таких больных оказалось 6 934, что составило 19\% от общего числа больных стенокардией. Но на этих больных было потрачено 57\% (149 406209 руб.) всех фринансовых средств, которые заплатило МСК за два года за своих застрахованных граждан, пролеченных в СМП и стационарах области по поводу стенокардии. Таким образом, можно выделить наиболее финансово затратные группы больных стенокардией и концентрировать на них усилия по профилактике ИМ. С увеличением числа обращений больных в стационар и СМП существенно росли затраты на лечение как на одного, так и на всех больных группы.

\section{Выводы:}

1. Вероятность развития ИМ у больных, обращающихся в лечебно-диагностические учреждения по поводу стенокардии, достаточно высока - 5,4\%, она возрастает до 5,5\% при обращении больных как со стенокардией, так и с АГ, и значительно меньше у пациентов, обращавшихся только с АГ- $0,42 \%$, и особенно низка у больных, не обращающихся за медицинской помощью ни со стенокардией, ни с АГ - 0,12\%.

2. Риск развития ИМ у больных стенокардий, а также со стенокардией и артериальной гипертонией в десятки раз, а в возрасте до 45 лет в сотни раз больше по сравнению с теми пациентами, которые не обращаются в лечебно-диагностические учреждения с этими диагнозами.

3. У мужчин, обращающихся за медицинской помощью с диагнозом «стенокардия», вероятность развития ИМ в 1,9 раза больше, чем у женщин, обращающихся в лечебные учреждения с тем же диагнозом.

4. С целью получения максимального клинического и экономического эффректа от первичной профрилактики ИМ ее следует проводить в первую очередь больным стенокардией, среди них в возрастной группе до 45 лет и от 45 до 59 лет, предпочтительно мужчинам, а также больным наиболее часто обращающимся за медицинской помощью по поводу стенокардии в СМП и стационар.

\section{ЛИТЕРАТУРА}

1. Бурыкин, И.М. Управление рисками в системе здравоохранения как основа безопасности оказания медицинской помощи / И.М. Бурыкин, Г.Н. Алеева, P.X. Хафризьянова // Современные проблемы науки и образования. - 2013. - № 1. - URL: www.scienceeducation.ru/107-8463 (дата обращения: 23.07.2014).

2. Боровиков, В.П. Statistica. Искусство анализа данных на компьютере: для профессионалов / В.П. Боровиков. - 2-е изд. - СПб.: Питер, 2003. - 688 с.

3. Закс, Л. Статистическое оценивание / Л. Закс. - М. Статистика, 1976. - 598 с.

4. Иванов, А.А. Риск-менеджмент: учеб.-метод. комплекс / А.А. Иванов, С.Я. Олейников, С.А. Бочаров. - М.: Издат. центр ЕАОИ, 2008. - 193 с.

5. Оганов, Р.Г. Сердечно-сосудистые заболевания в Российской Федерации во второй половине XX столетия: тенденции, возможные причины, перспективы / Р.Г. Оганов, Г.Я. Масленникова // Кардиология. 2000. - № 6. - С.4-8.

6. Самородская, И.В. Сердечно-сосудистая заболеваемость и факторы риска сердечно-сосудистых событий в РФ: ч.ІІ / И.В. Самородская // Кардиоваскуляр- ная терапия и профрилактика. - 2005. - № 3. C.94-100.

7. Чазов, Е.И. Инфаркт миокарда: прошлое, настоящее и некоторые проблемы будущего / Е.И. Чазов // Сердце. -2002 . - № 1. - С.6-8.

8. Чазова, И.Е. Современные подходы к лечению артериальной гипертонии / И.Е. Чазова // Consilium Medicum. Приложение. - 2001. - № 5. - C.11-19.

9. Явелов, И.С. Применение бета-адреноблокаторов при сердечно-сосудистых заболеваниях: современные рекомендации / И.С. Явелов // Consilium Medicum. 2005. — № 11. — C.945-956.

10. Independent risk factors for atrial fibrillation in a populationbased cohort. The Framingham Heart Study / E. Benjamin, D. Levy, S. Vaziri [et al.] // JAMA. — 1994. — Vol. 271. P.840-844.

11. Dubus, I. Origin and mechanisms of heart failure in hypertensive patients: left ventricular remodelling in hypertensive heart disease / I. Dubus, J.L. Samuel, W.B. Swynghedau // Eur. Heart J. — 1993. — № 14. P.76-81.

\section{REFERENCES}

1. Burykin, I.M. Upravlenie riskami v sisteme zdravoohraneniya kak osnova bezopasnosti okazaniya medicinskoi pomoschi [Risk management in the healthcare system is a basis for the safety of delivery of health care] / I.M. Burykin, G.N. Aleeva, R.H. Hafiz'yanova // Sovremennye problemy nauki i obrazovaniya [Modern problems of science and education]. - 2013. - № 1. - URL: www.scienceeducation.ru/107-8463 (data obrascheniya: 23.07.2014).

2. Borovikov, V.P. Statistica. Iskusstvo analiza dannyh na komp'yutere: dlya professionalov [Statistica. The art of data analysis on a computer: for the experts] / V.P. Borovikov. 2-e izd. - SPb.: Piter, 2003. - $688 \mathrm{~s}$

3. Zaks, L. Statisticheskoe ocenivanie [Statistical estimation] / L. Zaks. - M.: Statistika, 1976. - 598 s.

4. Ivanov, A.A. Risk-menedzhment: ucheb.-metod. kompleks [Risk management. Teaching materials] / A.A. Ivanov, S.YA. Oleinikov, S.A. Bocharov. - M.: Izd. centr EAOI, 2008. - $193 \mathrm{~s}$.

5. Oganov, R.G. Serdechno-sosudistye zabolevaniya v Rossiiskoi Federacii vo vtoroi polovine XX stoletiya: tendencii, vozmozhnye prichiny, perspektivy [Cardiovascular diseases in Russian Federation in the latter half of the 20th century: tendencies, potential causes, perspectives] / R.G. Oganov, G.Ya. Maslennikova // Kardiologiya [Cardiology]. - 2000. — № 6. - S.4-8.

6. Samorodskaya, I.V. Serdechno-sosudistaya zabolevaemost' i faktory riska serdechno-sosudistyh sobytii v RF: ch. II [Cardiovascular morbidity and risk factors for cardiovascular events in Russian Federation] / I.V. Samorodskaya // Kardiovaskulyarnaya terapiya i profilaktika [Cardiovascular Therapy and Prevention]. 2005. - № 3. - S.94-100.

7. Chazov, E.I. Infarkt miokarda proshloe, nastoyaschee i nekotorye problemy buduschego [Myocardial infarction the past, the present and some future challenges] / E.I. Chazov // Serdce [Heart]. - 2002. - № 1. S.6-8.

8. Chazova, I.E. Sovremennye podhody k lecheniyu arterial'noi gipertonii [The modern approaches to the treatment of arterial hypertension] / I.E. Chazova // Consilium Medicum. Prilozhenie [Consilium Medicum. Appendix]. — 2001. — № 5. - S.11-19.

9. Yavelov, I.S. Primenenie beta-adrenoblokatorov pri serdechno-sosudistyh zabolevaniyah: sovremennye rekomendacii [The beta-adrenergic blocking agents in cardiovascular diseases: the up-to-day guidance] / 
I.S. Yavelov // Consilium Medicum [Consilium Medicum]. 2005. — № 11. — S.945-956.

10. Independent risk factors for atrial fibrillation in a populationbased cohort. The Framingham Heart Study / E. Benjamin, D. Levy, S. Vaziri [et al.] // JAMA. — 1994. — Vol. 271. P.840-844.
11. Dubus, I. Origin and mechanisms of heart failure in hypertensive patients: left ventricular remodelling in hypertensive heart disease / I. Dubus, J.L. Samuel, W.B. Swynghedau // Eur. Heart J. — 1993. — № 14. P.76-81.

Принята 16.12.2014

(ㄱ С.А. Осипов, И.Ю. Малышева, З.М. Берхеева, 2015

УДК 614.2(470.41):616-057-082

\title{
ПРОШЛОЕ И НАСТОЯЩЕЕ ПРОФПАТОЛОГИЧЕСКОЙ СЛУЖБЫ В РЕСПУБЛИКЕ ТАТАРСТАН
}

СЕРГЕЙ АЛЬБЕРТОВИЧ ОСИПОВ, канд. меД. наук, зам. министра здравоохранения Республики Татарстан, Казань, Россия

ИРИНА ЮРЬЕВНА МАЛЫШЕВА, начальник Управления лечебной и профилактической помощи Минздрава Республики Татарстан, Казань, Россия

ЗУХРА МИНДИЯРОВНА БЕРХЕЕВА, канд. мед. наук, доцент кафедры гигиены, медицины труда ГБОУ ВПО «Казанский государственный медицинский университет» Минздрава России, Казань, Россия, тел. 8-905-310-74-46, e-mail: kgmu_profpat@mail.ru

Реферат. Цель исследования - изучить организацию профратологической службы в Республике Татарстан. Материал и методы. Проведен анализ нормативных документов, касающихся организации профпатологической помощи. Результаты и их обсуждение. Основы организации профратологической помощи работающим в Республике Татарстан были заложены в 1958 г., когда начали осуществляться первые консультации больных профессиональными заболеваниями. Первые 10 коек были выделены для больных профзаболеваниями на базе терапевтического отделения Городской больницы № 12 г. Казани в 1959 г., впоследствии преобразованные в самостоятельное отделение на 40 коек. В 1989 г. МЗ РТ было принято решение о создании Республиканского центра профессиональной патологии. Сегодня Центр профпатологии представлен круглосуточным стационарным отделением на 45 коек, 15-коечным дневным стационаром, амбулаторным приемом диспансерных больных. В республике создана современная профрпатологическая служба, предусматривающая оказание первичной медико-санитарной помощи работающим с вредными производственными фракторами и на вредных работах, и специализированной помощи в условиях Центра профратологии. Доказана оптимальность сотрудничества Центра профрпатологии и профильной кафедры медицинского университета, позволившая обеспечить преемственность оказания профпатологической помощи, внедрить автоматизированную информационную систему учета с формированием регистра больных, организовать дополнительное профессиональное образование по профпатологии.

Ключевые слова: профпатологическая служба, периодические медицинские осмотры, Центр профпатологии.

\section{OCCUPATIONAL PATHOLOGY SERVICES IN TATARSTAN: PAST AND PRESENT}

\author{
SERGEY A. OSIPOV, Ph.D., Deputy of Minister of Health of the Republic of Tatarstan, Kazan, Russia \\ IRINA YU. MALYSHEVA, Head of the treatment and prevention of the Ministry of Health of the Republic of Tatarstan,
} Kazan, Russia

ZUKHRA M. BERKHEEVA, M.D., associate professor of Department of hygiene and occupational health SBEI HPE «Kazan State Medical University» of Russian Ministry of Health, Kazan, Russia, tel. 8-905-310-74-46, e-mail: kgmu_profpat@mail.ru

\begin{abstract}
The aim of the research is to study the organization of occupational pathology services in the Republic of Tatarstan. Material and methods. The analysis of normative documents concerning the organization of occupational pathology services. Results and discussion. Fundamentals of occupational pathology workers in the Republic of Tatarstan were laid in 1958, when the first medical advices for occupational diseases performed. The first ten beds were in therapeutic department of city hospital number 12. In $1989 \mathrm{MOH}$ had decided to establish a National Center of occupational pathology. Today the center has 60 beds. Nowadays occupational pathology services provides primary health care to patients working in harmful production factors and conditions, and specialized health care in a center of pathology. Cooperation between the Centre and chair of occupational medicine of the Medical University, enabling continuity of treatment, assistance to implement a computerized accounting information system with the formation of the register of patients, organize additional professional education about occupational diseases.
\end{abstract}

Key words: occupational pathology service, periodic medical examinations, occupational pathology Centre.

еспублика Татарстан (РТ) является одним из крупнейших промышленных регионов Российской Федерации.

Основы организации профпатологической помощи работающим в РТ были заложены в 1958 г., когда начали осуществляться первые консультации больных профессиональными заболеваниями (ПЗ). В 1959 г. были выделены первые 10 коек для больных ПЗ на базе терапевтического отделения Городской больницы № 12 г. Казани, впоследствии преобразованные в самостоятельное отделение на 40 коек [1].

Первой заведующей отделением профпатологии стала Н.И. Фатеева, проработавшая в этой должности с 1961 по 1979 г. В штате отделения были предусмотрены ставка врача-терапевта, невропа- 
толога, заведующего (0,5 ставки) и врача-методиста (0,5 ставки). Помимо плановой госпитализации на протяжении ряда лет проводилась экстренная госпитализация как при профессиональных, так и бытовых отравлениях. Осуществлялись регулярные амбулаторные консультации больных, врачей медико-санитарных частей по вопросам профпатологии.

С целью координации оказания профпатологической помощи работающему населению в 1989 г. Министерством здравоохранения (МЗ) РТ было принято решение о создании Республиканского центра профессиональной патологии (РЦПП), базой которого стало существующее отделение профпатологии. Сегодня Центр профпатологии представлен круглосуточным стационарным отделением на 45 коек, 15-коечным дневным стационаром, амбулаторным приемом диспансерных больных.

С первых дней выделения профпатологических коек и до настоящего времени РЦПП МЗ РТ является клинической базой курса профессиональных болезней Казанского медицинского университета. Оптимальность такого сотрудничества доказана конкретными результатами работы.

Сотрудники отделения профпатологии совместно с преподавателями курса профессиональных заболеваний на должном уровне организовали лечебно-диагностический процесс. Многие годы функционировала школа профпатолога в медикосанитарных частях (МСЧ) предприятий: на заводе СК им. С.М. Кирова, заводе органического синтеза, химзаводе им. В.В. Куйбышева и др. Большая консультативная работа проводилась в МС4 Камского автомобильного завода, Чистопольского часового завода. Совместно с Республиканским комитетом профсоюзов РТ проверялась работа санаториев-профиллакториев предприятий, давались рекомендации по внедрению различных лечебнопрофрилактических комплексов.

На всем протяжении существования профпатологической службы в РТ практиковались проверки выполнения приказов М3 СССР № 400, 555, 700 , МЗ и МП РФ № 90, регламентирующих медицинское обслуживание работников, подвергающихся воздействию вредных и опасных производственных факторов.

В конце 90-х гг. в нашей стране система оказания медицинской помощи работающим гражданам претерпела существенные изменения, которые были связаны с реорганизацией и закрытием медико-санитарных частей. С одной стороны, это устраняло дублирование в оказании медицинской помощи и усиливало роль и ответственность единого лечащего врача за здоровье конкретного человека. С другой стороны, территориальные амбулаторнополиклинические учреждения оказались не готовы к полному спектру этой работы, в частности, к оценке влияния производственных факторов на состояние здоровья работающих.

Ситуация потребовала принятия ряда кардинальных решений: не просто переориентации работы врачей, а организации системы эффрективной и качественной профилактической работы, прежде всего с контингентом, работающим в контакте с неблагоприятными производственными факторами.

Приказом МЗ РТ был создан экспертный совет по профзаболеваниям, в компетенцию которого входит решение вопросов первичного установления связи заболевания с профессией, направления на медикосоциальную экспертизу (МСЭ), разбор конфликтных случаев, установление показаний направления больных за пределы республики.

Нами была разработана нормативная база, регламентирующая деятельность профпатологической службы в РТ и включающая приказ МЗ РТ от 01.03.1999 № 114 «О развитии профпатологической службы Республики Татарстан»; приказ МЗ РТ и ФГУ «Центр Госсанэпиднадзора в РТ» от 14.09.2001 № 142/849 «О приказе Минздрава РФ от 28.05.2001 № 176 «О совершенствовании системы расследования и учета профессиональных заболеваний в РФ»; приказ МЗ РТ от 14.02.2012 № 134 «Об организации и порядке проведения предварительных и периодических медицинских осмотров лиц, контактирующих с вредными и (или) опасными производственными факторами», приказ МЗ РТ от 02.12.2013 № 1682 «О порядке оказания медицинской помощи больным с острыми и хроническими профессиональными заболеваниями».

Проведение аккредитации и лицензирования медицинских учреждений по видам деятельности «Предварительные и периодические медицинские осмотры», «Экспертиза профпригодности» позволило не только оценивать качество оказания первичной медико-санитарной помощи работающим, но и способствовало изменению отношения руководителей медицинских учреждений к организации предварительных и периодических медицинских осмотров (ПМО) в части оснащения необходимым оборудованием и обучения врачей по вопросам профрпатологии. В настоящее время лицензии на проведение профилактических медосмотров и экспертизу профрпигодности имеют более 200 медицинских организаций РТ.

По инициативе кафедры был создан Республиканский регистр больных ПЗ, для которого были разработаны «Форма учета профрессионального больного, обследованного в Центре профпатологии» и программное обеспечение ввода, контроля информации и формирования информационной базы, позволяющей анализировать заболеваемость по годам, нозологическим формам, по территориям РТ, видам экономической деятельности, предприятиям, профессиям, полу, возрасту, стажу, результатам МСЭ и медицинской реабилитации [2]. Республиканский регистр содержит данные на 6500 человек, в том числе мужчин 70\%. В возрастном составе преобладают лица пенсионного возраста — как среди мужчин (55\%), так и женщин (53\%).

Важным аспектом совместной деятельности РЦПП МЗ РТ и курса профзаболеваний по профилактике ПЗ и несчастных случаев на производстве является организационно-методическая, консультативная и контрольная работа в сфрере медицинских осмотров. 


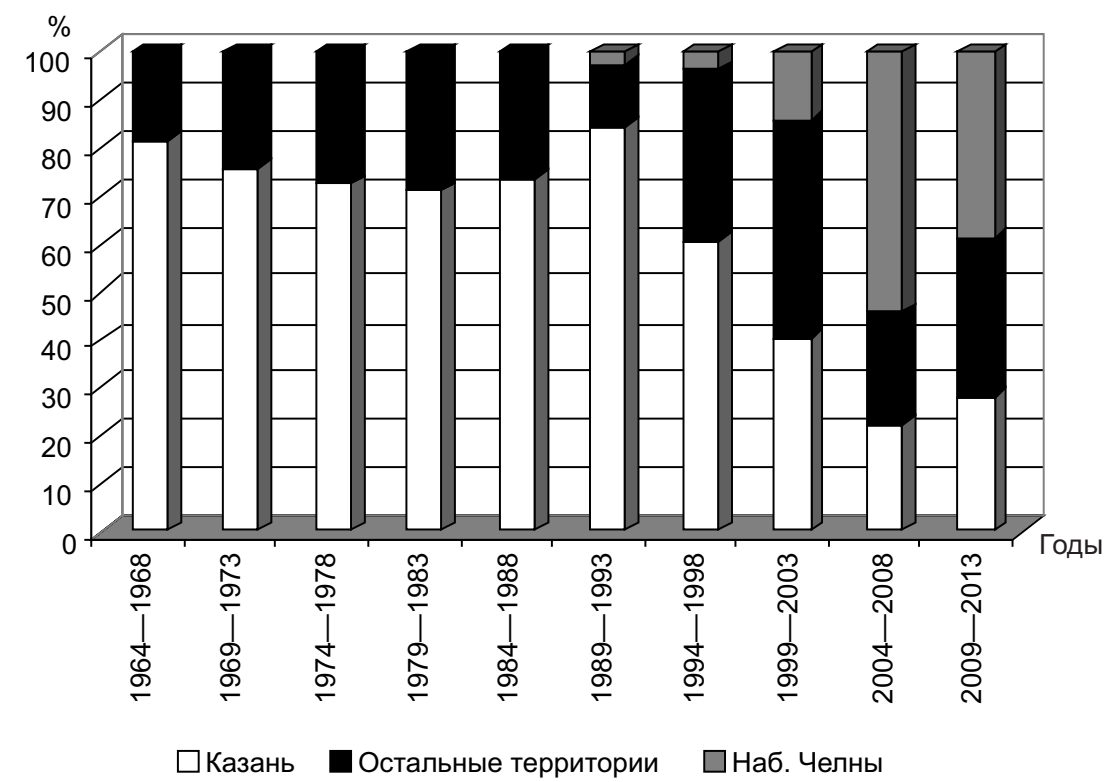

Территориальные закономерности распределения больных профессиональными заболеваниями

Нами проанализированы территориальные закономерности распределения больных профзаболеваниями. До 1999 г. среди пациентов отделения профпатологии преобладали жители г. Казани, составлявшие до $60 \%$ больных, в период с 2003 по 2013 г. наблюдается уменьшение удельного веса больных ПЗ до 22-27\% (рисунок).

Проверки качества проведения периодических медицинских осмотров в центральных районных больницах и г. Набережные Челны с обсуждением результатов на коллегиях и аппаратных совещаниях M3 РТ с участием Управления Роспотребнадзора по РТ привели к выявлению профессиональной патологии в сельских районах республики. Кардинально изменилась ситуация с направлением в Центр профпатологии работников заводов ОАО «КАМАЗ». В 1989-1998 гг. было 67 работников Камского автозавода из 2039 больных П3, что составило 3,3\%. В 2004-2008 гг. наблюдается максимальный удельный вес больных из г. Набережные Челны $(54,1 \%)$.

Одним из направлений в предупреждении профессиональной заболеваемости является медицинская профилактика, в основе которой лежит организация и проведение предварительных и ПМО работников, занятых на работах в контакте с вредными и опасными производственными факторами. Ежегодно ПМО в РТ проходят около 23 тыс. работников (2009 г. - 226 410, 2010 г. - 230 136, 2011 г. 230 136, 2012 г. - 224 670, 2013 г. - 286 210). В среднем охват ПМО составляет 93-96\%. Увеличение числа работников в 2013 г. связано с финансированием ПМО работников образовательных учреждений и учреждений социального обслуживания за счет бюджетных средств согласно Постановлению Кабинета министров РТ от 14 мая 2013 г.

По данным годовых статистических отчетов медицинских организаций, представленных в РЦПП МЗ РТ в 2013 г., периодическим медицинским осмотрам для определения профессиональной пригодности к работе в условиях воздействия вредных и неблагоприятных фракторов производственной среды, тяжелых работах подлежало 295428 работников. Осмотрено 96,8\% от подлежащих. В 2013 г. не прошли медицинский осмотр 9218 работников, в том числе 4256 женщин.

Сравнительный анализ отчетных данных за 2012-2013 гг. (табл. 1) показал, что 96\% работников

Та блица 1

Результаты периодических медицинских осмотров работников в 2012-2013 гг. (в абс.числах и \%)

\begin{tabular}{|c|c|c|c|c|}
\hline \multirow{2}{*}{ Показатель } & \multicolumn{2}{|c|}{2012 г. } & \multicolumn{2}{|c|}{2013 г. } \\
\hline & Абс. число & $\%$ & Абс. число & $\%$ \\
\hline Число осмотренных работников, \% охвата ПМО & 224670 & 96,5 & 282610 & 96,8 \\
\hline Не имели противопоказаний к выполняемой работе & 277573 & 96,7 & 278118 & 96,0 \\
\hline Имели временные противопоказания к работе & 1015 & 0,5 & 1258 & 0,43 \\
\hline Имели постоянные противопоказания к работе & 6082 & 2,8 & 3234 & 1,1 \\
\hline Нуждались в обследовании в Центре профпатологии & 2156 & 1,0 & 2381 & 0,8 \\
\hline Выявлено впервые хронических соматических заболеваний & 16043 & 7,5 & 23654 & 8,3 \\
\hline Нуждались в амбулаторном обследовании и лечении & 30716 & 14,2 & 40770 & 14,3 \\
\hline Нуждались в стационарном обследовании и лечении & 1817 & 0,8 & 2337 & 0,8 \\
\hline Нуждались в санаторно-курортном лечении & 21705 & 10,0 & 23360 & 8,2 \\
\hline Необходимо диспансерное наблюдение специалистов & 20633 & 9,5 & 32840 & 11,5 \\
\hline
\end{tabular}


были признаны годными для продолжения работы (2012 г. - 96,7\%).

Временный перевод на работы, не связанные с воздействием вредных и опасных производственных факторов и работ, рекомендован $0,43 \%$ работникам (2012 г. - 0,5\%). Постоянный перевод определен 3234 работникам (1,13\%), в 2012 г. - 6082 чел. $(2,8 \%)$.

Ключевым моментом медицинской реабилитации работников является оценка состояния их здоровья, связанного с условиями труда при проведении ПМО, с выделением групп риска развития ПЗ и ранжированием по степени необходимых профилактических и реабилитационных мероприятий

По результатам ПМО в 2013 г. было рекомендовано амбулаторное обследование и лечение 14,3\% осмотренных работников (2012 г. - 14,2\%), стационарное обследование и лечение - 0,8\% (2012 г. - 0,8\%), санаторно-курортное лечение 8,2\% (2012 г. - 10\%). Диспансерное наблюдение у специалистов необходимо 11,5\% осмотренных работников (2012 г. - 9,5\%). Впервые установлены хронические соматические заболевания у $8,2 \%$ (2012 г. - 7,5\%).

Подозрение на профессиональное заболевание установлено у 237 осмотренных работников (0,08\%). Количество диспансерных больных с установленными профессиональными заболеваниями составило 2144 человека, в течение 2013 г. осмотрено 1819 из них, что составило $84 \%$.

В 2013 г. в ходе ПМО не выявлено ни одного подозрения на профзаболевание в 16 районах (2012 г. 22, 2011 г. - 21, 2010 г. - 18, 2009 г. - 19). При этом в 13 из перечисленных районов номинально имеются подготовленные врачи-профпатологи.

Сравнительный анализ показателей профессиональной заболеваемости свидетельствует об уменьшении числа профзаболеваний, установленных в ходе ПМО (табл. 2) с 80,2\% в 2009 г. до $72,5 \%$ в 2013 г. Выявление подозрения на П3 при обращении за медицинской помощью зачастую приводит к диагностике профпатологии на поздних стадиях с утратой профессиональной трудоспособности. В 2009-2012 гг. данный показатель составляет 15-21,6\%, с резким уменьшением в 2013 г. до 7,5\%.

В то же время можно констатировать значительное уменьшение удельного веса больных ПЗ со стойкой утратой трудоспособности; в 2009 г. удельный вес инвалидов составил 4,5\%, в 2013 г. -
0,8\%. Почти в 2 раза в 2013 г. по сравнению с 2009 г. увеличилось количество больных, которым одновременно установлены 2 и более профзаболевания.

В связи с дальнейшим развитием профппатологической службы, реформированием первичного звена медицинского обеспечения работников возникла необходимость в увеличении числа профпатологов. Можно констатировать наличие двух категорий врачей, занимающихся профпатологией: врачи различных специальностей врачебных комиссий медицинских организаций, проводящих предварительные и периодические медицинские осмотры работников, и врачи-профпатологи медицинских организаций и центров профпатологии.

Обеспечение высокого качества первичной медико-санитарной помощи работающим с вредными производственными факторами возможно при наличии надлежащего уровня знаний по профпатологии у врачей всех специальностей, ведущих амбулаторный прием данного контингента [3].

В Казанском медицинском университете в 2005 г. была организована профессиональная переподготовка специалистов по профпатологии. Кроме того, проводится подготовка профпатологов в двухгодичной ординатуре. За анализируемый период прошли обучение 145 врачей РТ. Большинство из них совмещают работу врача-терапевта (врача общей практики), выполняя функции профпатолога на 0,25-0,5 ставки.

Подготовка и повышение квалификации врачейпрофпатологов осуществляется по специальным профессионально-образовательным программам первичной специализации в клинической ординатуре, профессиональной переподготовки специалистов, а также на циклах повышения квалификации. Вошло в практику проведение циклов не только в Казани, но и с выездом преподавателей непосредственно в муниципальные образования республики.

В 2009-2013 гг. проведен 41 цикл тематического усовершенствования. Обучение прошли 952 врача, участвующих в организации и проведении предварительных и периодических медицинских осмотров работающих

Конечно, сегодня нельзя говорить о том, что все проблемы решены. Однако можно констатировать, что созданная в республике система оказания профпатологической помощи дает определенные результаты. Вопросы охраны здоровья работающих

Таблица 2

Показатели профессиональной заболеваемости по Республике Татарстан в 2009-2013 гг.

\begin{tabular}{|c|c|c|c|c|c|}
\hline \multirow{2}{*}{ Наименование показателя } & \multicolumn{5}{|c|}{ Годы } \\
\hline & 2009 & 2010 & 2011 & 2012 & 2013 \\
\hline Удельный вес профзаболеваний, выявленных по результатам ПМО, \% & 80,2 & 71,7 & 79,6 & 69,3 & 72,5 \\
\hline Удельный вес лиц с утратой профессиональной трудоспособности, \% & 15 & 27 & 21,6 & 20,6 & 7,5 \\
\hline $\begin{array}{l}\text { Удельный вес лиц, которым установлено одновременно } 2 \text { и более } \\
\text { профзаболеваний, \% }\end{array}$ & 12,8 & 15,3 & 19,2 & 19,3 & 24,5 \\
\hline Удельный вес инвалидов вследствие проффзаболевания, \% & 4,5 & 7,4 & 4 & 1,16 & 0,8 \\
\hline
\end{tabular}


как одни из приоритетных находятся в зоне постоянного внимания руководителей органов здравоохранения республики, являются предметом обсуждения на коллегиях Минздрава с участием заинтересованных ведомств.

Заключение. Существующая региональная профпатологическая служба имеет многоуровневый характер и предусматривает оказание первичной медико-санитарной помощи работающим с вредными производственными факторами и на вредных работах и предоставляет специализированную помощь в условиях Центра профпатологии. Сотрудничество Центра профпатологии и профильной кафедры медуниверситета позволило внедрить автоматизированную информационную систему учета с формированием регистра больных П3, организовать дополнительное профессиональное образование по профпатологии.

Открытие кабинетов врача-профпатолога в медицинских организациях, имеющих лицензию на оказание медицинской помощи, включая работы и услуги по специальностям «экспертиза профпригодности» и «медицинские осмотры (предварительные, периодические)», безусловно, приблизило профпатологическую помощь работающим с вредными и опасными производственными фракторами.

Повышение профессионального уровня предварительных и периодических медицинских осмотров и обследований, диспансеризация позволяют не только выявлять фракторы риска и ранние признаки заболеваний, но и проводить активное предупреждение их развития.

\section{ЛИТЕРАТУРА}

1. Берхеев, И.М. Этапы развития профрпатологической службы в Республике Татарстан / И.М. Берхеев, А.Р. Вагизова, О.А. Пугачева, К.Р. Сафина // Материалы науч.практ. конф., посвящ. 45-летию организации профпатологической службы в Республике Татарстан. Казань, 2004. - С.17-23.

2. Берхеева, 3.М. Оценка региональной системы организации профпатологической помощи / З.М. Берхеева, Н.Х. Амиров, И.Ю. Малышева [и др.] // Медицина труда и промышленная экология. — 2011. - № 9. C.5-9.

3. Измеров, Н.Ф. Организация образовательной деятельности в сфере медицины труда: задачи, проблемы и пути преодоления / Н.Ф. Измеров, Л.В. Походзей, Т.В. Морозова // Профессия и здоровье: материалы Х Всерос. конгр., Москва, 6-8 декабря 2011 г. — М., 2012. - C.209-211.

\section{REFERENCES}

1. Berheev, I.M. Etapy razvitiya profpatologicheskoi sluzhby v Respublike Tatarstan / I.M. Berheev, A.R. Vagizova, O.A. Pugacheva, K.R. Safina // Materialy nauch.-prakt. konf., posvyasch. 45-letiyu organizacii profpatologicheskoi sluzhby $\vee$ Respublike Tatarstan. - Kazan', 2004. S.17-23.

2. Berheeva, Z.M. Ocenka regional'noi sistemy organizacii profpatologicheskoi pomoschi / Z.M. Berheeva, N.H. Amirov, I.Yu. Malysheva [i dr.] // Medicina truda i promyshlennaya ekologiya. - 2011. — № 9. - S.5-9.

3. Izmerov, N.F. Organizaciya obrazovatel'noi deyatel'nosti v sfere mediciny truda: zadachi, problemy i puti preodoleniya / N.F. Izmerov, L.V. Pohodzei, T.V. Morozova // Professiya i zdorov'e: materialy X Vseros. kongr., Moskva, 6-8 dekabrya 2011 g. - M., 2012. - S.209-211.

Принята 29.08.2014

\title{
ЭКОНОМИЧЕСКАЯ ЭФФЕКТИВНОСТЬ ПРИМЕНЕНИЯ ЛАЗЕРНЫХ ТЕХНОЛОГИЙ В УСЛОВИЯХ ХИРУРГИЧЕСКОГО СТАЦИОНАРА С КРАТКОСРОЧНЫМ ПРЕБЫВАНИЕМ ПАЦИЕНТОВ
}

СЕРГЕЙ ВЛАДИМИРОВИЧ ШАХРАЙ, канд. МеД. наук, доцент кафедры неотложной Хирургии

ГУО «Белорусская медицинская академия последипломного образования», руководитель Минского городского центра амбулаторной и малоинвазивной хирургии УЗ «11-я городская клиническая больница», Белоруссия, Минск, тел. +3-751-72-25-88-10, e-mail: s.shakhrai@mail.ru

ЮРИЙ МИХАЙЛОВИЧ ГАИН, докт. мед. наук, профессор кафедры неотложной хирургии, проректор по научной работе ГУО «Белорусская медицинская академия последипломного образования», Белоруссия, Минск, тел.+3-751-72-92-25-52, e-mail: nayka@belmapo.by ЮРИЙ ЮРЬЕВИЧ ПОЛУМИСКОВ, дИреКТор ЗАО «ФОТЭК», теЛ. +3-751-73-85-19-22

МИХАИЛ ЮРЬЕВИЧ ГАИН, ассистент кафедры неотложной хирургии ГУО «Белорусская медицинская академия последипломного образования», Белоруссия, Минск, тел. +3-751-72-25-88-10

ВЛАДИМИР ВЛАДИМИРОВИЧ ГРУША, канд. мед. наук, зам. главного врача по хирургии УЗ «11-я городская клиническая больница», Белоруссия, Минск, тел. +3-751-73-98-22-44

\begin{abstract}
Реферат. Цель — произвести оценку экономических эффектов использования разработанных авторами методов лечения отдельных видов хирургической патологии с применением лазерных технологий в условиях стационарного отделения с краткосрочным пребыванием пациентов. Материал и методы. Экономическую эффективность применения лазерных технологий оценивали при лечении пациентов с хроническим геморроем, хроническим парапроктитом, хронической анальной трещиной, варикозной болезнью нижних конечностей. Алгоритм расчета экономических эффектов состоял из суммарной оценки эффектов удельной экономии затрат на стационарное лечение, выплат пособий по временной нетрудоспособности, предотвращенных потерь валового внутреннего продукта как результата сокращения средней длительности нахождения пациентов на стационарном лечении. Результаты. Итоговый показатель экономии представлен коэффициентом полезности затрат. Общий показатель по результатам работы за 3 года составил 381 028,8 долл. США. Объем затрат на закупку лазерного
\end{abstract}


оборудования и расходные материалы составил сумму в эквиваленте 43200 долл. США, расходы на научнометодическое сопровождение работы - 17100 долл. США. Исходя из этого, чистый экономический эффект внедренных оперативных методов лечения в условиях стационара с краткосрочным пребыванием пациентов составил 320 728,8 долл. США. Коэффициент полезности затрат на приобретенное оборудование и научнометодическую работу составил 6,4.

Ключевые слова: хирургический лазер, хирургия краткосрочного пребывания, экономическая эффективность, малоинвазивные вмешательства.

\title{
ECONOMIC EFFICIENCY OF LASER TECHNOLOGIES USING IN SURGICAL HOSPITAL OF SHORT-TERM STAY
}

\author{
SERGEY V. SHAKHRAY, Ph.D., associate professor of Department of urgent surgery of BelMAPO, \\ Head of the Minsk city center of out-patient and minimally-invasive surgery of the 11th CCH, Belorusia, Minsk, \\ tel. +3-751-72-25-88-10, e-mail: s.shakhrai@mail.ru \\ YURIJ M. GAIN, M.D., Professor of Department of urgent surgery of BeIMAPO, vice rector of scientific work \\ of BeIMAPO, Belorusia, Minsk, tel. +3-751-72-92-25-52, e-mail: nayka@belmapo.by \\ YURIJ YU. POLUMISKOV, director of JSC «Fotec», Belorusia, Minsk, tel. +3-751-73-85-19-22 \\ MIKHAIL YU. GAIN, assistant of Department of urgent surgery of BelMAPO, Belorusia, Minsk, tel. +3-751-72-25-88-10 \\ VLADIMIR V. GRUSHA, Ph.D., the deputy chief physician on surgery of the 11th CCH, Belorusia, Minsk, \\ tel. +3-751-73-98-22-44
}

\begin{abstract}
Aim. The assessment of economic effects of use of the developed methods of treatment of several surgical diseases using laser technologies in the hospital of short-term stay conditions is made. Material and methods. Economic efficiency of laser technologies using was estimated by treatment of patients with chronic hemorrhoids, chronic paraproctitis, chronic anal fissure, a varicose disease of the feet. The algorithm of economic effects calculation consisted of a total score of effects of specific economy of costs of hospitalization, payments of temporary disability benefits, the prevented losses of Gross Domestic Product (GDP), as result of reduction of average duration of hospitalization. The total of economy is presented by coefficient of usefulness of expenses. Result. The general benefit by the results three years work was 381028,8 US dollars. The volume of costs of purchase of the laser equipment and expendables was the sum in an equivalent of 43200 US dollars, expenses on scientific and methodical work - 17100 US dollars. Pure economic effect of was 320728,8 US dollars. The coefficient of usefulness of costs of the acquired equipment and scientific and methodical work was 6,4.

Key words: surgical laser, surgery of short-term stay, economic efficiency, minimally-invasive surgery.
\end{abstract}

B ведение. Оптимизация лечебного процесса с акцентом внимания на уменьшение финансовых затрат и при этом качественное улучшение результатов лечения, ускорение послеоперационной реабилитации, минимизация осложнений и рецидивов у пациентов являются актуальной задачей хирургической службы любой организационной модели здравоохранения, в том числе и с бюджетным финансированием. Последние несколько десятков лет этому вопросу в отечественной и мировой литературе уделяется достаточно большое внимание. Смысл большинства публикаций сводится к разработке и внедрению в хирургическую практику минимально инвазивных методик при лечении широкого ряда патологий. При этом перед исследователями ставятся вполне конкретные задачи, а именно: высокая эфффективность этиопатогенетического воздействия; минимальная степень инвазии; оптимизация анестезиологического пособия; кратковременность стационарного этапа как самого дорогого в процессе лечения; быстрая послеоперационная реабилитация $[2,4,9,10,11$, $15,17,18,19,20]$. Все эти эфрфекты, несомненно, оказывают значимое влияние на экономическую и социальную составляющую лечебного процесса. Поэтому разработка и внедрение в практическое здравоохранение новых малоинвазивных методик лечения хирургической патологии, которые направлены на соблюдение основных принципов так называемой «хирургии одного дня», или «хирургии краткосрочного пребывания», являются актуальной и важной задачей современного здравоохранения $[1,6,8,9,10,14,17,20]$.

Прогрессивное развитие в мировой практике последние сто лет получили методики лечения, направленные на оптимальное сокращение сроков стационарного пребывания пациентов, что собственно и является одним из главных преимуществ применения структурно-организационной модели хирургического отделения, работающего по принципу «хирургия одного дня», при соблюдении условия равнозначного или более качественного результата лечения. При этом главным преимуществом является экономия материальных ресурсов. Организация подобного вида хирургической помощи особенно актуальна в местах концентрированного проживания населения. С точки зрения бюджетного здравоохранения данный вид помощи целесообразнее оказывать в хирургических центрах, которые интегрированы в стационарное хирургическое отделение. Лечебно-диагностические подразделения такого центра должны иметь возможность оказывать хирургическую помощь как в амбулаторном режиме, так и на условиях краткосрочного пребывания на хирургической койке [2, 3, 10, 11, 14, 15, 19].

На базе учреждения здравоохранения «11-я клиническая больница» г. Минска с 2009 г. функционирует Городской центр амбулаторной и малоинвазивной хирургии. В структурно-ффункциональную модель центра заложены принципы активного использования эффрективных малоинвазивных лечебных технологий у пациентов с различной 
общехирургической патологией, в том числе и при доброкачественных заболеваниях аноректальной области и варикозной болезни нижних конечностей. На 15 койках центра ежегодно проходят лечение около 2000 человек, из которых порядка 200 - это пациенты с заболеваниями аноректальной области и около 300 человек с варикозным расширением вен нижних конечностей.

Оценивая опыт применения малоинвазивных технологий в условиях центра, мы можем отметить, что экономический эффрект от внедрения конкретных хирургических технологий и методик складывается из нескольких позиций, а именно:

1. Кратковременность пребывания пациента в стационаре.

2. Отсутствие необходимости оснащения региональных амбулаторных учреждений здравоохранения дорогостоящей техникой за счет рационального интенсивного использования оборудования в рамках центра с концентрацией в них больных обслуживаемого региона.

3. Сокращение общей продолжительности периода временной нетрудоспособности.

4. Возможность амбулаторного лечения пациентов за счет разработки и внедрения эффрективных малоинвазивных технологий.

В стационарах Республики Беларусь государственного подчинения ежегодно оперируется порядка 4000 пациентов с хроническим геморроем, хронической анальной трещиной и свищами прямой кишки, около 15000 оперируются по поводу варикозной болезни нижних конечностей. В подавляющем большинстве случаев при лечении геморроя используется закрытая геморроидэктомия, при лечении анальной трещины - иссечение самой трещины и парафиссуральных тканей с дозированной сфинктеротомией, у пациентов с хроническим парапроктитом - иссечение свища в просвет кишки, при варикозной болезни применяется комбинированная фрлебэктомия. При этом в 98\% случаев сроки госпитализации варьируют от 6 до 21 койко-дня. Послеоперационная реабилитация в амбулаторных условиях в среднем по республике у данной категории пациентов составляет 22 дня (по данным за 2009-2012 гг.). Использование высокотехнологичного оборудования, позволяющего минимизировать сроки пребывания пациента в стационаре или перевести лечебный процесс в условия амбулаторного режима, составляет при этом не более 2-3\%. В соответствии с современными литературными данными, объем малоинвазивных вмешательств при аноректальной патологии в США и странах Западной Европы без госпитализации пациента составляет около 47-71\%, при варикозной болезни - 70-80\%, при этом имеется очевидная тенденция к ежегодному увеличению подобного объема амбулаторных вмешательств за счет разработки и внедрения эффрективных методик лечения с использованием высокотехнологичного оборудования. Малоинвазивные вмешательства у данной категории пациентов позволяют снизить агрессивность операции и способствуют сокращению сроков временной нетрудоспособности, улучшают качество жизни пациентов в послеоперационном периоде, позволяют сократить число послеоперационных осложнений $[5,7,12,13,16]$.

Все приведенные выше данные свидетельствуют о социальной и экономической значимости рассматриваемого вопроса для системы здравоохранения разных стран и диктуют необходимость разработки и внедрения современных малоинвазивных технологий лечения пациентов, которые направлены на уменьшение финансовых затрат государства и на улучшение конечных результатов лечения. В этой связи интерес могут представлять разработанные нами методики лечения отдельных видов хирургической патологии с использованием хирургического лазера.

Цель работы - оценка экономической эфффективности применения лазерного хирургического оборудования и технологии краткосрочного пребывания пациентов при лечении отдельных видов доброкачественной аноректальной патологии и варикозной болезни нижних конечностей.

Материал и методы. С 2009 г. на базе Минского городского центра амбулаторной и малоинвазивной хирургии при лечении хронического геморроя, хронической анальной трещины, хронического парапроктита (свищей прямой кишки) и варикозного расширения вен нижних конечностей начато использование хирургического лазерного аппарата «Медиола-компакт» (ЗАО ФОТЭК, Республика Беларусь). Конструктивные особенности аппарата позволяют одновременно манипулировать двумя длинами волн в инфракрасном диапазоне - 1560 и 970 нм и использовать различные типы вспомогательного инструментария. Для внутритканевой субмукозной лазерной деструкции при лечении геморроя применяется авторский вариант инструмента, позволяющий при погружении световода в узел получить эффект его объемной коагуляции (патент на полезную модель Республики Беларусь № 8755, патент на изобретение Республики Беларусь № 17224). Изолированная методика лазерной деструкции применяется у пациентов с 1-й и 2-й стадией хронического геморроя. При наличии анального пролапса слизистой (3-я и 4-я стадии заболевания) лазерная деструкция дополняется мукопексией.

При лечении хронической анальной трещины используется лазерная вапоризация парафиссуральных тканей с локальной фрармакологической соринктерорелаксацией или без нее (патент на изобретение Республики Беларусь № 17379). При лечении хронического парапроктита применяется методика изолированной интрафистулярной лазерной деструкции тканей, либо выполняется лазерная деконтаминация свищевого хода с последующей трансплантацией в его просвет и парафистулярно культуры аутологичных мезенхимальных стволовых клеток жировой ткани (рационализаторское предложение № 1601).

При лечении варикозной болезни нижних конечностей используется методика эндовенозной лазерной коагуляции, дополненной минифлебэктомией с применением авторского варианта инструментария для лазерного аппарата (патент на полезную модель 
Республики Беларусь № 9986). При использовании предложенных малоинвазивных методик во всех случаях получен клинический эфффект инволюции и исчезновения заболевания со значительным уменьшением интенсивности послеоперационной болевой и воспалительной реакций, что позволяет использовать эти методики в амбулаторных условиях или в условиях кратковременной госпитализации. Одной из характерных клинических особенностей применения лазерных технологий является достоверное ускорение периода послеоперационной реабилитации. Сравнительная оценка проведена с результатами лечения пациентов по традиционно широкоприменяемым методикам в лечебных учреждениях: комбинированная фрлебэктомия, закрытая геморроидэктомия, иссечение анальной трещины, иссечение ректального свища.

Расчет экономической эффективности применяемых лазерных методик произведен на основе анализа ряда интегрированных показателей с точки зрения удельной экономии затрат от предотвращенных потерь на стационарное лечение, экономией, связанной с уменьшением выплат пособий по временной нетрудоспособности, а также объема предотвращенных потерь валового внутреннего продукта в результате сокращения средней длительности лечения пациентов в условиях стационара. Экономическая эффективность также оценена с учетом рассчитанного коэффиццента полезности затрат. Расчеты произведены в рамках объема внедрения по научно-исследовательской работе в пересчете на численность оперированных пациентов за период с 2009 по 2012 г. в Минском городском центре амбулаторной и малоинвазивной хирургии на базе учреждения здравоохранения «11-я Городская клиническая больница».

Экономическая эффрективность результатов лечения рассчитана на основе оценки сравнительных показателей средней длительности лечения пациентов в пяти учреждениях здравоохранения г. Минска и Минской области.

Алгоритм расчета экономических эффектов и эффрективности включал следующие этапы:

1. На основе справочных данных производили вычисление показателей для проведения основных расчетов.

2. На основе сравнительной характеристики средней длительности пребывания пациентов в стационаре производили расчет предотвращенных потерь койко-дней и дней временной нетрудоспособности.

3. Определялся размер удельной экономии затрат по каждой исследуемой нозологии.

4. На ее основе определяли экономические эффекты от предотвращенных потерь затрат на лечение, выплату пособий по временной нетрудоспособности и предотвращенных потерь внутреннего валового продукта.

5. Определяли общий экономический эффрект.

6. Рассчитывали коэффрициент экономической эфффективности затрат.

Затраты учреждения здравоохранения «11-я Городская клиническая больница» на выполнение операций по поводу аноректальной патологии составили 43200 долл. США. В эту стоимость входило приобретение лазерного хирургического аппарата «Медиола-компакт» и расходного инструментария к нему. Объем внедрения в рамках научно-исследовательской работы за 3 года включал выполнение 697 операций. При этом 492 пациента были пролечены в режиме краткосрочной госпитализации и 205 - в амбулаторном режиме (без госпитализации). Выполненные в центре хирургические вмешательства по стадии и степени тяжести патологического процесса (как и другие характеристики пациентов - средний возраст, гендерная принадлежность, фон сопутствующей патологии) статистически не различались с группой сравнения $(p>0,05)$.

Расчет показателей экономической эффрективности и экономического эффекта для оценки лечебной деятельности Минского городского центра амбулаторной и малоинвазивной хирургии производили исходя из среднегодовых ценовых показателей за период с 2009 по 2012 г.:

1. Средняя стоимость одного койко-дня в профильном стационаре составил сумму в эквиваленте 57 долл. США.

2. Средний размер пособий по временной нетрудоспособности за календарный день в анализируемый период составил 9,5 долл. США.

3. Средний размер внутреннего валового продукта (ВВП) на одного занятого в экономике за календарный день составил 23,5 долл. США.

Фактические и расчетные данные по оценке экономических эффректов и экономической эффективности лечебной деятельности Минского городского центра амбулаторной и малоинвазивной хирургии по разделу общей проктологии приведены в табл. 1-5, показатели деятельности статистически обработаны, показатели стоимости представлены в эквиваленте к долларам США в соответствии с правилами округления цифр.

Результаты и их обсуждение. Сравнительная оценка усредненных показателей длительности пребывания пациентов на хирургическом стационарном лечении в сравниваемых для анализа учреждениях здравоохранения по разделу плановой хирургической помощи за период 2009-2012 гг. показала, что данная статистическая величина в Минском городском центре амбулаторной и малоинвазивной хирургии в разы оказалась меньше, чем в других учреждениях (рис. 1).

Полученный результат уменьшения средней продолжительности пребывания пациентов на хирургической койке в условиях Минского городского центра амбулаторной и малоинвазивной хирургии, несомненно, повлек за собой определенный экономический эффрект, который в разрезе сэкономленных средств на стационарное лечение складывался из предотвращенных потерь дней временной нетрудоспособности и затрат на стационарное лечение (рис. 2). В объеме выполненных операций и малоинвазивных вмешательств экономический эффект примененных схем организации лечебного процесса и непосредственно внедренных лазерных хирурги- 
Сравнительная характеристика средней длительности пребывания пациентов в стационаре

\begin{tabular}{|c|c|c|c|c|}
\hline \multirow{2}{*}{$\begin{array}{l}\text { Наименование } \\
\text { заболевания }\end{array}$} & \multicolumn{2}{|c|}{$\begin{array}{c}\text { Минский городской центр амбулаторной } \\
\text { и малоинвазивной хирургии }\end{array}$} & \multicolumn{2}{|c|}{$\begin{array}{c}\text { Учреждения здравоохранения } \\
\text { Республики Беларусь }\end{array}$} \\
\hline & $\begin{array}{c}\text { Кол-во } \\
\text { пациентов }\end{array}$ & 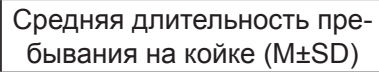 & $\begin{array}{c}\text { Кол-во } \\
\text { пациентов }\end{array}$ & 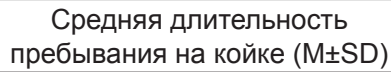 \\
\hline Варикозное расширение вен & 261 & $2,0 \pm 0,3$ & 7341 & $8,2 \pm 0,7$ \\
\hline Хронический геморрой & 251 & $1,4 \pm 0,2$ & 4321 & $8,6 \pm 0,5$ \\
\hline Хроническая анальная трещина & 132 & $1,2 \pm 0,1$ & 1631 & $7,9 \pm 0,3$ \\
\hline Хронический парапроктит & 53 & $2,3 \pm 0,2$ & 217 & $8,1 \pm 0,4$ \\
\hline
\end{tabular}

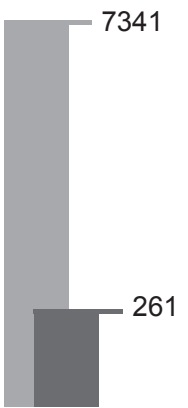

Варикозное расширение вен

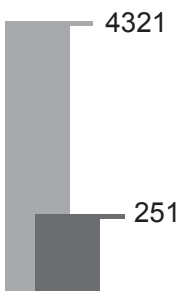

Хронический гемморой

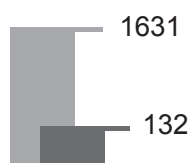

Хроническая анальная трещина

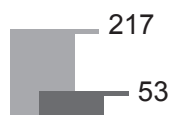

Хронический парапроктит

Количество пациентов Минского городского центра амбулаторной и малоинвазивной хирургии

Количество пациентов учреждений здравоохранения РБ

Рис. 1. Сравнительная характеристика количества пациентов с проктологической патологией

Таблица 2

Предотвращенные потери дней временной нетрудоспособности за счет сокращения средней длительности лечения в условиях стационара

\begin{tabular}{|l|c|c|c|}
\hline \multicolumn{1}{|c|}{ Наименование заболевания } & $\begin{array}{c}\text { Предотвращенные потери } \\
\text { койко-дней на 1 случай ста- } \\
\text { ционарного лечения, дней }\end{array}$ & $\begin{array}{c}\text { Удельный вес лиц } \\
\text { трудоспособного } \\
\text { возраста, \% }\end{array}$ & $\begin{array}{c}\text { Предотвращенные потери } \\
\text { дней временной нетрудо- } \\
\text { способности, дней }\end{array}$ \\
\hline Варикозное расширение вен & 6,2 & 72 & 1618,2 \\
\hline Хронический геморрой & 7,2 & 79 & 1427,8 \\
\hline Хроническая анальная трещина & 6,7 & 86 & 760,5 \\
\hline Хронический парапроктит & 5,8 & 73 & 225,6 \\
\hline
\end{tabular}

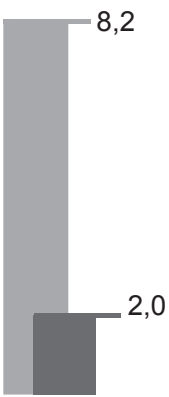

Варикозное расширение вен

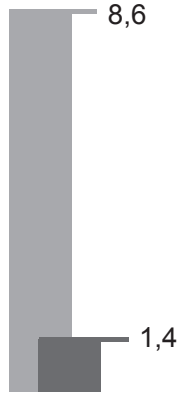

Хронический гемморой

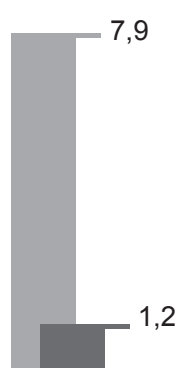

Хроническая анальная трещина

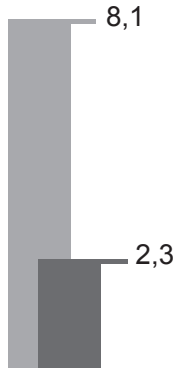

Хронический парапроктит

Средняя длительность пребывания на койке (M+SD)

в Минском городском центре амбулаторной и малоинвазивной хирургии

Средняя длительность пребывания на койке $(\mathrm{M} \pm \mathrm{SD})$

в учреждениях здравоохранения РБ

Рис. 2. Сравнительная характеристика средней длительности пребывания пациентов в стационаре с проктологической патологией, в днях 
Экономический эффект от предотвращенных потерь затрат на лечение за счет сокращения средней длительности лечения в условиях стационара

\begin{tabular}{|l|c|c|}
\hline \multicolumn{1}{|c|}{ Наименование заболевания } & $\begin{array}{c}\text { Удельная экономия затрат } \\
\text { от предотвращенных потерь } \\
\text { на стационарное лечение, долл. }\end{array}$ & $\begin{array}{c}\text { Экономическая эффективность } \\
\text { от предотвращенных потерь } \\
\text { на стационарное лечение, долл. }\end{array}$ \\
\hline Варикозное расширение вен & 353 & 92133 \\
\hline Хронический геморрой & 410 & 102910 \\
\hline Хроническая анальная трещина & 382 & 50424 \\
\hline Хронический парапроктит & 331 & 17543 \\
\hline Итого & 1476 & 263010 \\
\hline
\end{tabular}

Т а блица 4

Экономический эффект от предотвращенных потерь на выплаты пособий по временной нетрудоспособности за счет сокращения средней продолжительности лечения в условиях стационара

\begin{tabular}{|l|c|c|}
\hline \multicolumn{1}{|c|}{ Наименование заболевания } & $\begin{array}{c}\text { Предотвращенные потери дней } \\
\text { временной нетрудоспособно- } \\
\text { сти, календ. дней }\end{array}$ & $\begin{array}{c}\text { Экономический эффрект от предотвращен- } \\
\text { ных поть на выплаты пособий по времен- } \\
\text { нойрудоспособности, долл. }\end{array}$ \\
\hline Варикозное расширение вен & 1165,1 & 11068,5 \\
\hline Хронический геморрой & 1427,8 & 13564,1 \\
\hline Хроническая анальная трещина & 760,5 & 7224,8 \\
\hline Хронический парапроктит & 225,6 & 2143,2 \\
\hline Итого & 3579,0 & 34000,6 \\
\hline
\end{tabular}

Таблица 5

Экономический эффект от предотвращенных потерь внутреннего валового продукта за счет сокращения средней длительности лечения в условиях стационара краткосрочного пребывания пациентов

\begin{tabular}{|l|c|c|}
\hline \multicolumn{1}{|c|}{ Наименование заболевания } & $\begin{array}{c}\text { Удельная экономия затрат } \\
\text { от предотвращенных потерь ВВП, долл. на } \\
1 \text { пациента }\end{array}$ & $\begin{array}{c}\text { Экономический эфрект } \\
\text { от педотвращенных потерь ВВП, долл. }\end{array}$ \\
\hline Варикозное расширение вен & 145,7 & 27245,9 \\
\hline Хронический геморрой & 169,2 & 33501,6 \\
\hline Хроническая анальная трещина & 157,5 & 17955 \\
\hline Хронический парапроктит & 136,3 & 5315,7 \\
\hline Итого & 608,7 & 84018,2 \\
\hline
\end{tabular}

ческих методик у пациентов общепроктологического профиля составил 297 010,6 долл. США. Эта сумма чистой экономии системы здравоохранения на оказание помощи пациентам на стационарном этапе лечения.

Однако экономическая эффективность организационной модели оказания хирургической помощи и применения конкретных лечебных методик рассматривалась нами не только с позиции экономии средств за счет сокращения расходов на пребывание в стационаре, но и экономии по выплатам за дни временной нетрудоспособности стационарного этапа лечения. Она также оценена с учетом участия в лечебном процессе категории лиц, занятых в реальном секторе экономики. При этом был рассчитан экономический эффрект от предотвращенных потерь внутреннего валового продукта. Для этого был оценен объем предотвращенных потерь валового внутреннего продукта за счет сокращения средней продолжительности лечения в условиях стационара краткосрочного пребывания трудоспособной категории лиц. При анализе работы центра данный показатель экономии средств составил 84 018,2 долл. США.
Таким образом, общий экономический эффект от сокращения длительности лечения пациентов с применяемыми лазерными технологиями в указанных нозологических группах в условиях стационара краткосрочного пребывания Минского городского центра амбулаторной и малоинвазивной хирургии складывается из трех показателей, а именно: экономического эффректа от предотвращенных потерь затрат на стационарное лечение, экономического эфрфекта от предотвращенных потерь на выплаты пособий по временной нетрудоспособности и экономического эфректа от предотвращенных потерь внутреннего валового продукта. Указанный итоговый показатель по результатам работы за 3 года составил 381 028,8 долл. США. Объем затрат на закупку лазерного оборудования и расходных материалов составил 43200 долл. США, расходы на научно-методическое сопровождение работы - 17100 долларов США. Исходя из этого, чистый экономический эффект внедренных оперативных методов лечения в условиях стационара с краткосрочным пребыванием пациентов составил 320 728,8 долл. США. При этом коэффициент полезности затрат на приобретенное оборудование и научно-методическую работу составляет 6,4 (рис. 3). 


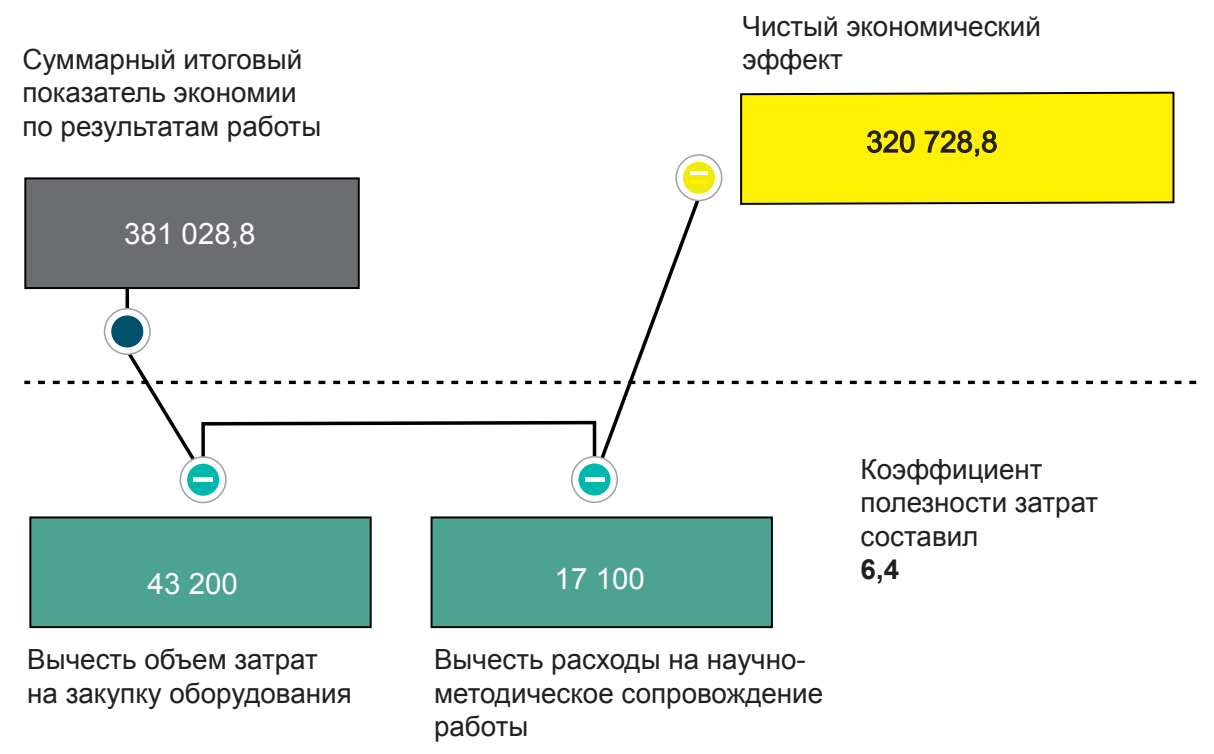

Рис. 3. Суммарный итоговый показатель экономии по результатам работы за 3 года, долл. США

\section{Заключение}

1. Применение лазерных методик в лечении отдельных видов хирургической патологии в структуре функциональной модели организации хирургической помощи по принципу «хирургия одного дня» позволяет минимизировать сроки стационарного пребывания пациента и связанные с этим фринансовые расходы.

2. Использование научно-методического сопровождения после приобретения лечебным учреждением хирургического оборудования с целью разработки и клинического внедрения нового инструментария и методик лечения позволяет дать хорошую экономическую отдачу с коэффрициентом полезности затрат 6,4 в объеме представленных оперативных вмешательств.

3. Полученные результаты указывают на то, что инвестирование средств в развитие стационарозамещающих хирургических технологий, в том числе с применением лазерного оборудования, базирующихся на научной методологической основе, позволяет получить высокие показатели рентабельности с быстрой окупаемостью финансовых затрат.

\section{ЛИТЕРАТУРА}

1. Богачев, В.Ю. Эндовазальная лазерная облитерация большой подкожной вены при варикозной болезни / В.Ю. Богачев, А.И. Кириенко, И.А. Золотухин [и др.] // Ангиология и сосудистая хирургия. — 2004. — № 1. — C.93-100.

2. Бредихин, С.В. Организация и пятилетний опыт работы поликлинического центра амбулаторной хирургии / С.В. Бредихин, Ю.А. Пархисенко // Амбулаторная хирургия. - 2009. - № 2. - С.6-9.

3. Воробьев, В.В. Возможности амбулаторной хирургии / В.В. Воробьев [и др.] // Хирургия. — 2010. — № 3. C.49-53.

4. Возможности амбулаторной хирургии стационарозамещающих технологий в лечении больных с паховыми грыжами / А.Д. Тимошин [и др.] // Амбулаторная хирургия. - 2011. - № 1. - С.3-8.

5. Воробьев, Г.И. Основы колопроктологии / Г.И. Воробьев. - Ростов-н/Д.: Феникс, 2001. - 416 с.
6. Гавриленко, А.В. Эндовазальная лазерная коагуляция в лечении варикозной болезни / А.В. Гавриленко, П.Е. Вахратьян, Я.Ю. Муравьева // Хирургия. 2008. - № 7. - С.60-63.

7. Гейнии, А.В. Лазеры в хирургическом лечении геморроя / А.В. Гейниц, Т.Г. Елисова // Лазерная медицина. 2009. - № 1. - С.31-35.

8. Гужков, О.Н. Оценка эфффективности сочетанного применения эндовазальной лазерной коагуляции и эхосклеротерапии в комплексном лечении осложненных форм варикозной болезни / О.Н. Гужков // Ангиология и сосудистая хирургия. — 2007. - № 3. - С.95-99.

9. Ждановский, В.В. Амбулаторная герниология: возможные объемы помощи в структуре муниципального здравоохранения / В.В. Ждановский // Амбулаторная хирургия. - 2011. - № 2. - С.25-27.

10. Калининская, А.А. Стационарозамещающие фрормы медицинской помощи: организация и эффективность деятельности / А.А. Калининская, А.Ф. Стукалов, Т.Т. Аликова // Здравоохранение Российской Федерации. - 2008. - № 6. - С.5.

11. Корецкая, Л.Р. Частичная госпитализация в стационаре как гигантский экономический резерв / Л.Р. Корецкая, М.А. Шаповалова // Современные исследования социальных проблем. - 2011. - № 3. C. $48-53$.

12. Кузьминов, А.М. Геморроидэктомия с применением высоких энергий / А.М. Кузьминов, И.Ф. Борисов // Колопроктология. — 2009. - № 3. - С.46-52.

13. Мухин, А.Г. Лечение геморроя в амбулаторных условиях / А.Г. Мухин, А.В. Волков, М.Ю. Комарова // Колопроктология. - 2010. - № 1. - С.18-21.

14. Организация работы центра амбулаторной хирургии на базе многопрофильного лечебно-профилактического учреждения / В.И. Ельсиновский [и др.] // Амбулаторная хирургия. - 2009. - № 2. - С.12-13.

15. Попов, А.П. Некоторые аспекты амбулаторно-поликлинической работы в современных условиях / А.П. Попов, Ю.П. Лановенко, И.В. Павлова // Военномедицинский журнал. - 2011. — № 11. - С.14-19.

16. Ривкин, В.Л. Руководство по колопроктологии / В.Л. Ривкин, А.С. Бронштейн, С.Н. Файн. - М.: Медпрактика, 2001. - 300 c.

17. A23-hour care centre model for th management of surgical patients / R. Ryan [et al.] // Australian New Zealand Journal of Surgery. — 2004. — Vol. 74. — P.754-759. 
18. Cheng, H.H. Overnight-stay patients in a day surgery unit to overco shortage of inpatient beds / H.H. Cheng, L. Newman // British Journal of Oral and Maxillofacial Surgery. - 2005. - Vol. 43. - P.169-172.

19. Day surgery: operational guide. - London: Department of Health, 2002. - $40 \mathrm{p}$.

20. Kok, K. The 23-hour ward: an efficient alternative to day case surgery / K. Kok, C. Hayhurst, P. Wilson // British Journal of Health Care Management. - 2006. Vol. 12. - P.15-17.

\section{REFERENCES}

1. Bogachev, V.Yu. Endovazal'naya lazernaya obliteraciya bol'shoi podkozhnoi veny pri varikoznoi bolezni / V.Yu. Bogachev, A.I. Kirienko, I.A. Zolotuhin [i dr.] // Angiologiya i sosudistaya hirurgiya [Angiology \& Vasc. surgery]. — 2004. — № 1. - S.93-100.

2. Bredihin, S.V. Organizaciya i pyatiletnii opyt raboty poliklinicheskogo centra ambulatornoi hirurgii / S.V. Bredihin, Yu.A. Parhisenko // Ambulatornaya hirurgiya. 2009. — № 2. - S.6-9.

3. Vorob'ev, V.V. Vozmozhnosti ambulatornoi hirurgii / V.V. Vorob'ev [i dr.] // Hirurgiya [Surgery]. — 2010. № 3. - S.49-53.

4. Vozmozhnosti ambulatornoi hirurgii stacionarozameschayuschih tehnologii $v$ lechenii bol'nyh s pahovymi gryzhami / A.D. Timoshin [i dr.] // Ambulatornaya hirurgiya. - 2011. - № 1. - S.3-8.

5. Vorob'ev, G.I. Osnovy koloproktologii / G.I. Vorob'ev. Rostov-n/D.: Feniks, 2001. - $416 \mathrm{~s}$.

6. Gavrilenko, A.V. Endovazal'naya lazernaya koagulyaciya v lechenii varikoznoi bolezni / A.V. Gavrilenko, P. E. Vahrat'yan, YA. Yu. Murav'eva // Hirurgiya [Surgery]. 2008. — № 7. - S.60-63.

7. Geinic, A.V. Lazery v hirurgicheskom lechenii gemorroya / A.V. Geinic, T.G. Elisova // Lazernaya medicina [Laser medicine]. -2009 . — № 1. - S.31-35.

8. Guzhkov, O.N. Ocenka effektivnosti sochetannogo primeneniya endovazal'noi lazernoi koagulyacii i ehoskleroterapii v kompleksnom lechenii oslozhnennyh form varikoznoi bolezni / O.N. Guzhkov // Angiologiya i sosudistaya hirurgiya [Angiology \& Vasc. surgery]. 2007. — № 3. — S.95-99.
9. Zhdanovskii, V.V. Ambulatornaya gerniologiya: vozmozhnye ob'emy pomoschi $v$ strukture municipal'nogo zdravoohraneniya/ V.V. Zhdanovskii // Ambulatornaya hirurgiya. - 2011. — № 2. - S.25-27.

10. Kalininskaya, A.A. Stacionarozameschayuschie formy medicinskoi pomoschi: organizaciya i effektivnost' deyatel'nosti / A.A. Kalininskaya, A.F. Stukalov, T.T. Alikova // Zdravoohranenie Rossiiskoi Federacii. - 2008. № $6 .-\mathrm{S} .5$.

11. Koreckaya, L.R. CHastichnaya gospitalizaciya v stacionare kak gigantskii ekonomicheskii rezerv / L.R. Koreckaya, M.A. Shapovalova // Sovremennye issledovaniya social'nyh problem. - 2011. — № 3. - S.48-53.

12. Kuz'minov, A.M. Gemorroidektomiya s primeneniem vysokih energii / A.M. Kuz'minov, I.F. Borisov // Koloproktologiya [Coloproctology]. - 2009. - № 3. - S.46-52.

13. Muhin, A.G. Lechenie gemorroya $\vee$ ambulatornyh usloviyah / A.G. Muhin, A.V. Volkov, M.Yu. Komarova // Koloproktologiya [Coloproctology]. — 2010. — № 1. S.18-21.

14. Organizaciya raboty centra ambulatornoi hirurgii na baze mnogoprofil'nogo lechebno-profilakticheskogo uchrezhdeniya / V.I. El'sinovskii [i dr.] // Ambulatornaya hirurgiya. - 2009. - № 2. - S.12-13.

15. Popov, A.P. Nekotorye aspekty ambulatorno-poliklinicheskoi raboty $v$ sovremennyh usloviyah / A.P. Popov, Yu.P. Lanovenko, I.V. Pavlova // Voenno-medicinskii zhurnal. - 2011. - № 11. - S.14-19.

16. Rivkin, V.L. Rukovodstvo po koloproktologii / V.L. Rivkin, A.S. Bronshtein, S.N. Fain. - M.: Medpraktika, 2001. $300 \mathrm{~s}$.

17. A23-hour care centre model for th management of surgical patients / R. Ryan [et al.] // Australian New Zealand Journal of Surgery. — 2004. - Vol. 74. — P.754-759.

18. Cheng, H.H. Overnight-stay patients in a day surgery unit to overco shortage of inpatient beds / H.H. Cheng, L. Newman // British Journal of Oral and Maxillofacial Surgery. - 2005. - Vol. 43. - P.169-172.

19. Day surgery: operational guide. — London: Department of Health, 2002. - $40 \mathrm{p}$.

20. Kok, $K$. The 23-hour ward: an efficient alternative to day case surgery / K. Kok, C. Hayhurst, P. Wilson // British Journal of Health Care Management. — 2006. Vol. 12. - P.15-17.

Принята 20.12.2014 


\section{ПРАВИЛА ОФОРМЛЕНИЯ СТАТЕЙ И ТЕЗИСОВ ДЛЯ АВТОРОВ В ЖУРНАЛ И ПРИЛОЖЕНИЯ «ВЕСТНИК СОВРЕМЕННОЙ КЛИНИЧЕСКОЙ МЕДИЦИНЫ" ISSN 2071-0240 (PRINT), ISSN 2079-553X (ONLINE)}

1. Статья должна быть набрана в текстовом редакторе Word 2003-2013, шрифтт Times New Roman, 12, межстрочный интервал 1,5, форматирование по ширине, без переносов, должна быть напечатана на одной стороне листа форматом А4. Поля: сверху 25 мм, снизу 20 мм, слева 30 мм, справа 15 мм. Стиль статей должен быть ясным и лаконичным.

2. В начале первой страницы статьи указывают (через пробел между ними):

1) () инициалы и фамилии всех авторов через запятую, год (например: () Н.Б. Амиров, А.А. Визель, Е.В. Хазова, 2015);

2) код по УДК;

3) название статьи (ЗАГЛАВНЫМИ БУКВАМИ) должно отражать основное содержание работы и обязательно должно быть представлено на русском и английском языках.

4) имя, отчество и фамилию(и) автора(ов) полностью, после каждой фамилии указать ученую степень, ученое звание, занимаемую должность, полное название кафедры (подразделения), учреждения, города, страны, где работает(ют) автор(ы), на русском языке и их перевод на английский язык, контактный телефон и е-mail;

5) реферат, структурированный и отражающий основное содержание статьи, на русском языке (не менее 100 и не более 250 слов) и перевод структурированного реферата на английский язык (не менее 100 и не более 250 слов).

Редакция оставляет за собой право исправлять присланные авторами на английском языке без согласования с авторами название статьи, реферат и ключевые слова при противоречии их правилам английского языка или неправильного употребления терминологии. Например: внебольничная пневмония. Неправильный перевод: out-of hospital pneumonia. Правильный перевод: community acquired pneumonia;

6) ключевые слова, отражающие смысловую часть статьи (не более 6), на русском языке и их перевод на английский язык.

3. Принимаются к опубликованию статьи на английском языке, при этом должны быть выполнены все требования как для русскоязычных статей, но с обратным переводом соответственно.

4. Статья должна сопровождаться официальным направлением от учреждения, в котором выполнена работа, иметь визу научного руководителя, направление должно быть скреплено печатью учреждения, направляющего работу в редакцию журнала. Если работа представляется от нескольких учреждений, необходимо сопроводительное письмо, подтверждающее направление статьи для публикации в журнале, от каждого из них (необязательно, если нет конфликта интересов между учреждениями). В направлении можно указать, является ли статья диссертационной.

5. Все статьи направляются на рецензирование. Редакция оставляет за собой право сокращать и редактировать присланные статьи. Не допускается направление в редакцию работ, напечатанных в других изданиях или направленных для печати в другие издания.
6. В конце статьи должны быть подписи всех авторов с указанием ученой степени и звания, полностью указаны фамилия, имя, отчество, место работы и должности всех авторов, контактный адрес, номер телефона и адрес электронной почты одного из авторов.

7. Высылать статью в печатном и электронном виде на удобном для авторов носителе данных (CD-R, CD$\mathrm{RW}$ или фрлеш-накопитель) одновременно с квитанцией об оплате по адресу: 420043, Казань, ул. Вишневского, 57-83 для Н.Б. Амирова или 420012, Казань, ул. Бутлерова, 49, КГМУ, в редколлегию журнала ВСКМ для Н.Б. Амирова и по е-mail: vskmjournal@gmail.com. Файл называется по фамилии первого автора. Если у первого автора несколько статей, то им присваиваются номера после фрамилии, например: Амиров Н.Б.-1, Амиров Н.Б.-2 и т.д. Приветствуется направление фото первого автора в формате jpeg.

8. Рубрикация журнала: Передовая статья. Оригинальные исследования (клинико-теоретические публикации). Обзоры. Клинические лекции. Краткие сообщения. Организация здравоохранения. Дискуссии. Съезды, конференции, симпозиумы. Из практического опыта. История медицины (юбилейные и исторические даты). Экспериментальные исследования - клинической медицине. Клинический случай и др.

9. Объем статей в рубрику «Оригинальные исследования» не должен превышать 15 страниц, число рисунков - не более 5-6; таблицы должны быть построены наглядно, иметь название над таблицей, их заголовки должны точно соответствовать содержанию граф (междустрочный интервал в таблицах - 1); таблицы не должны представлять собой отсканированное изображение; рисунки должны иметь номер и название под рисунком. Отсканированные фотографии должны иметь разрешение не ниже 300 dpi. Текст: все части статьи (текст, таблицы, рисунки и т.п.) должны быть приведены полностью в соответствующем месте статьи. Все цифры, итоги, проценты в таблицах должны быть тщательно выверены автором и должны соответствовать цифрам в тексте. В тексте необходимо указать ссылки на таблицы и рисунки и их порядковые номера. Статья должна быть тщательно отредактирована и выверена автором. Статьи объемом до 6 страниц могут быть размещены в рубрике «Краткие сообщения». В рубрику «Из практического опыта» принимаются статьи, освещающие оригинальный опыт авторов в медицинской практике. Объем статьи должен составлять не более 10 страниц машинописного текста.

Объем обзорно-теоретических статей и статей в рубрику «Клинические лекции» заранее согласовываются с редакцией журнала.

Рисунки, таблицы, реферат и список литературы входят в общий объем статьи.

В структуру статей входят разделы: Введение (с указанием в конце целей исследования). Материал и методы. Результаты и их обсуждение. Выводы. Перечень цитируемой литературы.

10. Библиографические ссылки в тексте статьи надо давать в квадратных скобках с указанием номера 
согласно списку литературы: Например: ...согласно данным [11]...

В конце статьи приводится список литературы в соответствии с ГОСТ 7.1-2003 «Библиографическая запись. Библиографическое описание. Общие требования и правила составления» (для обзоров - не более 50, для оригинальных статей - не более 20 источников), в котором цитируемые авторы перечисляются в алфравитном порядке (сначала на русском, затем на иностранных языках). После фрамилии автора(ов) указываются названия работ, место издания, издательство, год издания, номер тома и выпуска, страницы (от - до) и ГОСТ Р7.0.5-2008 «Система стандартов по информации, библиотечному и издательскому делу. Библиографическая ссылка. Общие требования и правила составления».

Для вхождения в базу данных Scopus необходимо подавать список цитируемой русскоязычной литературы в романской транскрипции и перевод на английский язык в квадратных скобках. Для этого можно воспользоваться сайтом: http://translit.ru. Во избежание ошибок, а также для облегчения работы не стоит делать транслитерацию вручную. Представление в References только транслитерированного (без перевода) описания недопустимо, так как делает такое описание совершенно нечитаемым (поэтому, после транслитерированного названия необходимо поместить перевод названия статьи на английском языке в квадратных скобках). N.B.! Если в списке есть иностранные публикации, то они полностью повторяются в русскоязычном списке литературы. Зарубежные базы данных огромное внимание уделяют правильной индексации ссылок. Таким образом, после списка литературы на русском, необходимо поместить References по указанному примеру:

Borisov, A.G. Spaechnaya bolezn' bryushnoi polosti [Adhesive abdominal disease] / A.G. Borisov, A.A. Volodin, I.R. Mihaylov [i dr.] // Endoskopicheskaya hirurgiya [Endoscopic surgery]. - 2011. - T. 4, № 3. S.51-63.

Примечание. Допускается порядок списка литературы по мере цитирования.

\section{ОБРАЗЕЦ ОФОРМЛЕНИЯ СТАТЬИ \\ И СПИСКА ЛИТЕРАТУРЫ}

() Н.Н. Крывкина, Э.Н. Ахмадеева, А.Я.Валиуллина, 2015

Пробел

УДК 616-053.3:616.329-089

Пробел

СРАВНИТЕЛЬНАЯ ХАРАКТЕРИСТИКА ЗДОРОВЬЯ ДЕТЕЙ МЛАДЕНЧЕСКОГО ВОЗРАСТА, РОДИВШИХСЯ НЕДОНОШЕННЫМИ, В ЗАВИСИМОСТИ ОТ МАССЫ ТЕЛА ПРИ РОЖДЕНИИ

Пробел

Наталья Николаевна Крывкина, аспирант кафедры госпитальной педиатрии ГБОУ ВПО «Башкирский государственный медицинский университет» Минздрава России, Уфа, Россия, тел. 8-917-34-555-28, e-mail: sunnatali@msn.com

Эльза Набиахметовна Ахмадеева, докт. мед. наук, профессор, зав. кафедрой госпитальной педиатрии ГБОУ ВПО «Башкирский государственный медицинский университет» Минздрава России, Уфа, Россия, тел. 8-903-312-37-57, e-mail: pediatr@ufanet.ru
Альфия Ягуфраровна Валиуллина, канд. мед. наук, ассистент кафедры госпитальной педиатрии ГБОУ ВПО «Башкирский государственный медицинский университет» Минздрава России, Уфа, Россия, тел. 8-937-322-60-78, e-mail: doctoralfiya@gmail.com

\section{Пробел}

Реферат. Цель исследования - охарактеризовать здоровье детей младенческого возраста, родившихся недоношенными. Материал и методы. Под наблюдением находилось 519 недоношенных детей, которых разделили на 3 группы: 1-я группа - дети с экстремально низкой массой тела при рождении (44 ребенка), 2-я группа - дети с очень низкой массой тела при рождении (142 младенца) и 3-я группа - дети с низкой массой тела при рождении (333 младенца). Результаты и их обсуждение. Выявлено, что исходы перенесенных заболеваний у недоношенных детей исследуемых групп к концу первого года жизни были разнообразными - от практически здоровых до детей с ограниченными возможностями. Заключение. Факторами риска, влияющими на тяжесть исходов, являются отягощенный акушерско-гинекологический анамнез матери в $100 \%$ случаев, сам фракт недоношенности и весовая категория преждевременно родившихся младенцев.

\section{Пробел}

Ключевые слова: новорожденные, дети с низкой и экстремально низкой массой тела, раннее развитие недоношенных.

Пробел

THE COMPARATIVE CHARACTERISTICS OF HEALTH PREMATURE INFANTS DEPENDING ON THEIRS BIRTH WEIGHT

\section{Пробел}

Natalia N. Kryvkina, graduate student of Department of hospital pediatrics of SBEI HPE «Bashkir State Medical University» Russian Ministry of Health, Ufa, Russia, tel. 8-917-345-55-28, e-mail: sunnatali@msn.com

Elsa N. Akhmadeeva, M.D., Professor, Head of Department of hospital pediatrics of SBEI HPE «Bashkir State Medical University» Russian Ministry of Health, Ufa, Russia, tel. 8-903-312-37-57, e-mail: pediatr@ufanet.ru

Alfia Ya. Valiullina, Ph.D., assistant of Professor of Department of hospital pediatrics of SBEI HPE «Bashkir State Medical University» Russian Ministry of Health, Ufa, Russia, tel. 8-937-322-60-78, e-mail: doctoralfiya@ gmail.com

\section{Пробел}

Abstract. Aim. The purpose of our study was to characterize health of premature infants. Matherial and method. Under our observation were 519 children. We divided them into 3 groups. In the first group were 44 preterm birth with extremely low birth weight. In the second -142 premature with very low birth weight. And in the last one -333 children with low birth weight. Results. It was revealed that outcomes of perinatal pathologies during first year of life were variables. It occur such healthy children as invalid infants. Conclusion. Factors, which may cause severe pathology, were not only the fact of preterm born, but also the compromised obstetric-gynecologic history of mothers in $100 \%$ of cases.

Пробел

Key words: premature infants, extremely low birth weight, obstetric-gynecologic history.

\section{Пробел}

Текст структурированной статьи 


\section{Пробел}

\section{Литература}

1. Аржанова, О.Н. Этиопатогенез невынашивания беременности / О.Н. Аржанова, Н.Г. Кошелева // Журнал акушерства и женских болезней. - 2004. - T. LIII, № 1. - С.37-41.

2. Виноградова, И.В. Катамнестическое наблюдение за детьми с экстремально низкой массой тела при рождении / И.В. Виноградова, М.В. Краснов, Л.Г. Ногтева // Практическая медицина. - 2008. - № 31. C.67-69.

3. Antenatal Corticosteroids Prior to 24 WEEKS "Gestation and Neonatal Outcome of Extremely Low Birth Weight Infants» / S. Abbasi, C. Oxford, J. Gerdes [et al.] // Am. J. Perinatol. - 2009. - Vol. 32. - P.19-23.

4. Gagliardi, L. Bronchopulmanary dysplasia and brain white matter damage in preterm infants: a complex relationship / L. Gagliardi, R. Bellu, R. Zanini // Pediatr. Perinat. Epidemiol. - 2009. - Vol. 23, № 6. - P.90582.

\section{Пробел}

\section{References}

1. Arzhanova, O.N. Etiopatogenez nevynashivaniya beremennosti [Aetiopathogenesis of recurrent pregnancy loss] / O.N. Arzhanova, N.G. Kosheleva // Zhurnal akusherstva i zhenskih boleznei [Obstetrics and gynecopathy journal]. — 2004. - T. LIII, № 1. - S.37-41.

2. Vinogradova, I.V. Katamnesticheskoe nablyudenie za det'mi s ekstremal'no nizkoi massoi tela pri rozhdenii [Follow-up of children with extremally low birth weight] / I.V. Vinogradova, M.V. Krasnov, L.G. Nogteva // Prakticheskaya medicina [Practical medicine]. - 2008. № 31. - S.67-69.

3. Antenatal Corticosteroids Prior to 24 WEEKS «Gestation and Neonatal Outcome of Extremely Low Birth Weight Infants» / S. Abbasi, C. Oxford, J. Gerdes [et al.] // Am. J. Perinatol. - 2009. - Vol. 32. - P.19-23.

4. Gagliardi, L. Bronchopulmanary dysplasia and brain white matter damage in preterm infants: a complex relationship / L. Gagliardi, R. Bellu, R. Zanini // Pediatr. Perinat. Epidemiol. — 2009. — Vol. 23, № 6. — P.90—582.

11. Краткие сообщения и тезисы предоставляются объемом не более 1-4 страниц машинописного текста без иллюстраций, таблиц и списка литературы, структурированные как тезисы: название ЗАГЛАВНЫМИ БУКВАМИ. С новой строки - Ф.И.О. автора(ов) полностью. С новой строки учреждение, город, страна. С новой строки через интервал - цель исследования, материал и методы, результаты и их обсуждение, выводы (заключение). При оформлении кратких сообщений в сокращенном виде редакция оставляет за собой право опубликовать их в приложении к журналу. Перевод кратких сообщений и тезисов на английский язык увеличивает вероятность цитирования англоязычными авторами.

12. Сокращения слов, имен, названий (кроме общепринятых сокращений фризических мер, химических и математических величин и терминов) не допускаются. Единицы измерений должны быть приведены в системе СИ.

13. При формировании материалов конференций и съездов в приложение к журналу принимаются тезисы. Правила оформления тезисов такие же, как для коротких сообщений.

14. Уважаемые коллеги! В связи с тем, что статьи и сведения в статьях, публикуемых в научно-практическом журнале «Вестник современной клинической медицины», будут помещаться в ведущих российских и мировых библиографических и рефреративных изданиях, в электронных информационных системах, включая размещение их электронных копий в базе данных Научной электронной библиотеки (НЭБ), представленной в виде научного информационного ресурса сети Интернет www.elibrary.ru, а также включаться в одну из трех систем цитирования Web of Science: Science Citation Index Expanded (база по естественным наукам), Social Sciences Citation Index (база по социальным наукам), Arts and Humanites Citation Index (база по искусству и гуманитарным наукам), Scopus, Web of Knowledge, Astrophysics, PubMed, Mathematics, Chemical Abstracts, Springer, Agris, GeoRef, авторы оригинальных статей должны предоставлять на безвозмездной основе редакции журнала права на использование электронных версий статей, соблюдать международные правила построения публикаций и резюме к ним. Направление статей в журнал по умолчанию считается согласием авторов на безвозмездное использование электронных версий статей.

15. Статьи, оформленные не в соответствии с указанными правилами, не рассматриваются редколлегией и не возвращаются.

16. В связи с тем, что журнал издается на средства авторов и подписчиков, стоимость публикации одной страницы формата A4 составляет 600 (шестьсот) рублей. Квитанция об оплате присылается вместе со статьей.

Реквизиты для перевода:

ООО «ММЦ «Современная клиническая медицина» ОГРН 1131690016677:

ИНН/КПП 1655265546 / 165501001

Р/счет 40702810500000002685

в ОАО АИКБ «Татфондбанк» г. Казань

БИК 049205815

Кор./счет 30101810100000000815 в ГРКЦ НБ РТ

17. С очных аспирантов (единственный автор) за публикацию рукописей плата не взимается.

18. Правила оформления статей могут совершенствоваться в соответствие с требованиями ВАК и Scopus. Следите за изменениями на сайтах журнала, а также в последнем вышедшем номере журнала.

По возникающим вопросам обращаться в редколлегию журнала: Амиров Наиль Багаувич (главный редактор), e-mail: namirov@mail.ru; Визель Александр Андреевич (зам. главного редактора), e-mail: lordara@ mail.ru; Хазова Елена Владимировна ученый секретарь редколлегии), e-mail: hazova_elena@mail.ru; Шаймуратов Рустем Ильдарович (компьютерное сопровождение журнала), e-mail: russtem@gmail.com. Телефон редакции: +7 (843) 291-26-76, факс +7 (843) 277-88-84, www. vskmjournal.org

По вопросу размещения рекламы в журнале и оформлению договоров обращаться в отдел договоров и рекламы ООО «ММЦ «Современная клиническая медицина». Контактное лицо, руководитель отдела Амирова Рената Наилевна, 420043, Казань, ул. Вишневского, 5783, тел. 8-903-307-99-47; e-mail: renata1980@mail.ru

Подробная информация о журнале, а также полные версии публикаций размещаются в открытом доступе на сайтах: www.vskmjournal.org, www.kgmu.kcn.ru,

www.es.rae.ru/vskm, www.cyberleninka.ru, https:// twitter.com/vskmjournal 


\section{THE BULLETIN OF CONTEMPORARY CLINICAL MEDICINE ISSN 2071-0240 (PRINT), ISSN 2079-553X (ON LINE) THE RULES FOR ARTICLES REGISTRATION FOR AUTHORS}

1. The article should be edited in Word, Times New Roman font size of 12 , interval of 1,5 , in width formatting, non carrying, interval in tables of 1 only on one side of the sheet. Printing fields should be 25 мм from top, 20 мм from the bottom, $30 \mathrm{~mm}$ from left, $15 \mathrm{~mm}$ from right. Pages should not be numbered. Article style should be laconic and clear.

2. Please, register on the first page of article according to the followings: (through the blank):

1) (C) initials and surname of all authors, year (for example: () N.B. Amirov, A.A. Vizel, E.V. Khazova, 2015);

2) code of the UDC;

3) TITLE OF ARTICLE (IN CAPITAL LETTERS) in Russian and English;

4) names of authors (full); scientific degrees, position, full name of the department, institution, contact phone number and e-mail address (in Russian and English);

5) abstracts of the article in Russian (from 100 to 250 words) and English $6)$

6) key words in Russian and English (not more than

3. Article written in English is accepted for publishing (according to the same rules with the abstract and key words translated into Russian).

4. The article should be referred by official letter from Institution where the basic material for article was performed with stamp and signed by research director. If article referred from the few foundations letters of recommendation should be applied from each foundation. Please, mention if article reflects materials from thesis.

5. All articles are peer-reviewed. Editorial Committee keeps rights to reduce and edit articles (in coordination with authors). Articles already published or directed in (to) other Editions are not accepted.

6 . Each author of the article should sign in the end of the article and mention his full name, position and scientific degree in foundation, corresponding address with telephone number and e-mail address of one of the authors.

7. 1 copies of the article should be mailed to the Editorial Committee with electronic copy (floppy 3,5" 1,44 MB, CD-R, CD-RW), e-mail: vskmjournal@gmail.com, namirov@mail.ru, lordara@mail.ru, hazova_elena@mail. ru, russtem@gmail.com. This copy should be named by first author. If the first author sends a few articles they will be consecutively numbered, for example: Amirov N.B.-1, Amirov N.B.-2, and so on. A photo of the first author in .jpg format is welcomed.

8. Rubrication of articles: Leading article. Original articles (clinical and theoretical papers). Surveys. Lections.
Brief information. Reviews. Discussions. Conventions, symposiums, conferences, Meetings, Societies. Jubelee dates, History of Medicine. Clinical trials.

9. Volume of paper referring to «Original investigations» should not exceed 15 pages and numbers of pictures $5-6$, tables must be set presentable, clearly titled, according to the text (with interval of 1). All parts of the text should be placed on its own order. All figures and results, in tables must be thoroughly checked by authors and meet figures in text. All tables should be placed in the right order. Pictures and tables are included in article volume. In rubric "From practical experience» papers reflecting authors original experience in medical practice are accepted in volume of not more than 10 pages. Volume of the articles of «theoretical review» and "Clinical lections» suppose to be discussed with Editorial Committee beforehand.

Article content: introduction with aim and tasks of the investigation; material and methods; results; discussion; conclusion (s); refereeing literature.

10. Bibliographic references in text should be given in numbers in square brackets according to the list of the literature. Example: according to the data [11] ... References list should be given in the end of the article (for Reviews not more than 50 sources, for Original papers not more than 20). Cited authors should be followed by alphabetical order (first in Russian, then in foreign languages (English). After author's names the title of the article, place of edition, editorial year, source volumes, numbers and pagers should be given. (following the ГОСТ 7.1-2003 «Bibliographic description of documents»).

Note: List of the literature according to citation could be allowed.

Words, names and titles abbreviation (except terms, rates and values widely used in physics, chemistry, mathematic) not allowed. Measuring units ought to be in the Système International (SI) units.

11. Abstracts of the conferences and congresses are accepted to the Supplement of the Journal. Rules for the abstracts are the same as for the Brief Information.

12. Articles made out of required rules wouldn't be considered and returned back to authors.

13. Publication for post-graduate students is free.

Phone +7(843)291-26-76; fax +7(843)277-88-84. www. vskmjournal.org, www.kgmu.kcn.ru, www.es.rae.ru/vskm, www.cyberleninka.ru, https://twitter.com/vskmjournal. Department of advertising: «Modern Clinical Medicine», 57-83, Vishnevsky str., Kazan-city, Republic of Tatarstan, Russia, 420043. Renata N. Amirova, tel. +7-903-307-9947; e-mail: renata1980@mail.ru 


\section{ПОРЯДОК РЕЦЕНЗИРОВАНИЯ РУКОПИСЕЙ, НАПРАВЛЯЕМЫХ \\ НА ПУБЛИКАЦИЮ В НАУЧНО-ПРАКТИЧЕСКИЙ ЖУРНАЛ «ВЕСТНИК СОВРЕМЕННОЙ КЛИНИЧЕСКОЙ МЕДИЦИНЫ»}

1. Принимаются только рецензии от доктора наук - специалиста той области науки, которой посвящена статья и не являющегося руководителем или консультантом диссертационного исследования автора статьи. Подпись доктора наук должна быть заверена гербовой печатью организации, в которой работает рецензент. К статье могут прилагаться рецензии нескольких докторов наук.

2. Все статьи оцениваются рецензентами по следующим параметрам:

- оригинальность статьи;

- значимость статьи;

- качество статьи;

- способ представления материала;

- адекватность цитируемых источников;

- степень соответствия рубрикам журнала.

\section{ПРИМЕРНАЯ СТРУКТУРА РЕЦЕНЗИИ НА СТАТЬЮ}

В редакцию журнала «Вестник современной клинической медицины» РЕЦЕНЗИЯ

на статью:<авторы, название> "—_" 20

Статья посвящена решению актуальной задачи<...>

В ней рассматривается<...>; предлагается<...>

По статье можно сделать следующие замечания<...>

Статья содержит новые результаты, представляет интерес для специалистов в области<...>и может быть рекомендована к публикации в научном журнале «Вестник современной клинической медицины».

В случае отрицательного мнения рецензента о возможности публикации необходимо обоснование или рекомендации по доработке рукописи.

Должность, ученая степень, ученое звание

Подпись

Расшифровка подписи

Дата

О себе (рецензент) сообщаю:

Фамилия

Имя, отчество

Организация

Ученая степень

Звание, должность

E-mail

@

Служ.тел. (с кодом города)

Факс (с кодом города)

моб. тел. или дом. тел.

Почтовый адрес (с индексом)

Личная подпись рецензента:

\section{Уважаемые коллеги!}

Направляя рецензию на статью для научного журнала «Вестник современной клинической медицины», вы тем самым удостоверяете, что данная статья содержит новые интересные результаты и заслуживает публикации.

Редакция журнала благодарит вас за сотрудничество. 


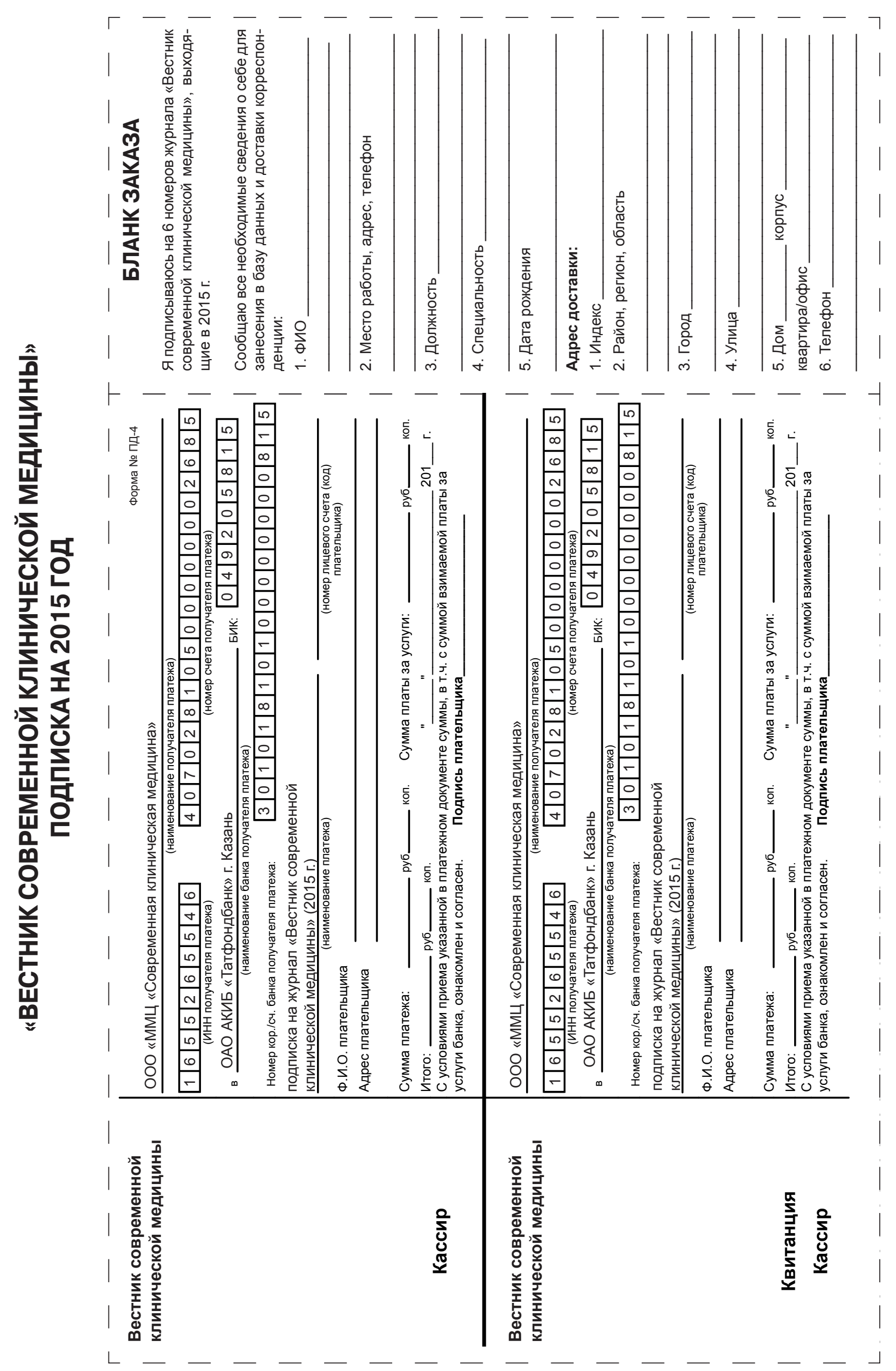


Решением президиума ВАК научно-практический журнал «Вестник современной клинической медицины» включен в перечень российских рецензируемых научных журналов, в которых публикуются основные научные результаты диссертаций на соискание научных степеней доктора и кандидата наук (редакция от 25.05.2012).

Журнал распространяется среди широкого круга практикующих врачей на специализированных конференциях и выставках.

Электронная версия журнала, состав редакционной коллегии и редакционного совета, а также правила для авторов и рецензентов размещены в свободном доступе на сайтах: www.vskmjournal.org, www.kgmu.kcn.ru, e-library.ru, cyberleninka.ru, www.es.rae.ru.vskm, twitter.com/vskmjournal, sites.google.com/site/vskmjournal/home 